\title{
Impacts of Periodic Dredging on Macroinvertebrate Prey Availability for Benthic Foraging Fishes in Central San Francisco Bay, California
}

Open-File Report 2020-1086

U.S. Department of the Interior

U.S. Geological Survey 
Cover Photo: Dredge operating in a shallow subtidal region of San Francisco Bay, California. Photo by Hannah Mittelstaedt, U.S. Geological Survey, May 4, 2017. 


\section{Impacts of Periodic Dredging on Macroinvertebrate Prey Availability for Benthic Foraging Fishes in Central San Francisco Bay, California}

By Susan E. W. De La Cruz, Isa Woo, Laurie Hall, Alison Flanagan, and Hannah Mittelstaedt

Open-File Report 2020-1086 


\title{
U.S. Department of the Interior \\ DAVID BERNHARDT, Secretary
}

\author{
U.S. Geological Survey \\ James F. Reilly II, Director
}

U.S. Geological Survey, Reston, Virginia: 2020

For more information on the USGS - the Federal source for science about the Earth, its natural and living resources, natural hazards, and the environment—visit https://www.usgs.gov or call 1-888-ASK-USGS.

For an overview of USGS information products, including maps, imagery, and publications, visit https://store.usgs.gov/.

Any use of trade, firm, or product names is for descriptive purposes only and does not imply endorsement by the U.S. Government.

Although this information product, for the most part, is in the public domain, it also may contain copyrighted materials as noted in the text. Permission to reproduce copyrighted items must be secured from the copyright owner.

Suggested citation:

De La Cruz, S.E.W., Woo, I., Hall, L., Flanagan, A., and Mittelstaedt, H., 2020, Impacts of periodic dredging on macroinvertebrate prey availability for benthic foraging fishes in central San Francisco Bay, California: U.S. Geological Survey Open-File Report 2020-1086, 96 p., https://doi.org/10.3133/ofr20201086.

ISSN 2331-1258 (online) 


\section{Acknowledgments}

Full implementation (Phase IV) of this study was funded by the U.S. Army Corps of Engineers (USACE), whereas earlier pilot and study plan development (Phases I-III) were funded by the San Francisco Estuary Institute (SFEI) Regional Monitoring Program and the Port of Oakland. The study was recommended by the National Marine Fisheries Service through the Long-Term Management Strategy (LTMS) Programmatic Consultation on Essential Fish Habitat and the San Francisco Bay LTMS for the Placement of Dredged Sediment in the Bay Region, including the USACE, U.S. Environmental Protection Agency, San Francisco Bay Conservation and Development Commission, and San Francisco Bay Regional Water Quality Control Board.

We thank J. A. Hobbs, S. Hamilton, and F. Feyrer for fisheries consultations, J. Yee (U.S. Geological Survey, USGS) for statistical guidance, and J. Donald, Y. Chan, C. Garcia, A. Ravani, C. Norton, D. Nelson, M. Hill, M. Tzen, S. Morris, C. Tolle, C. Birdsall, D. Turner, G. Bongey, S. Meyers, and R. Babuka for laboratory and field assistance. T. Graham (USGS), J. Adams (USGS), A. Loveland (San Francisco Public Utilities Commission), Bay Planning Coalition, and the SFEI Regional Monitoring Program Exposure and Effects Workgroup provided helpful review comments that improved the overall clarity of this report. 



\section{Contents}

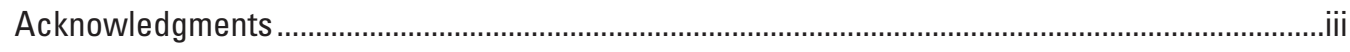

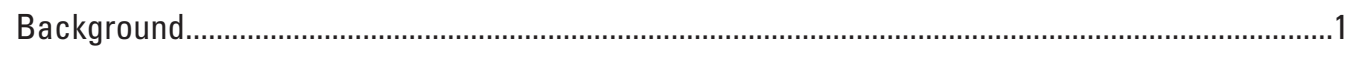

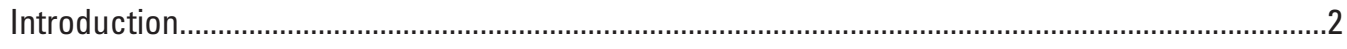

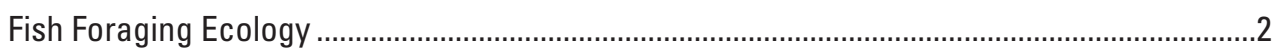

Macroinvertebrate Prey Availability.......................................................................................

Assessing Benthic Recovery After Maintenance Dredging ..................................................

Measuring Structural and Functional Recovery ..............................................................

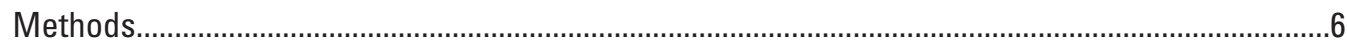

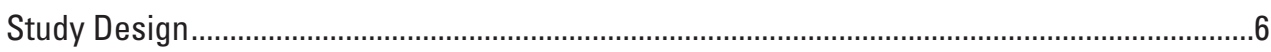

Modified Benthic Resources Assessment Technique (MBRAT) Framework ....................6

Study Area and Site Selection...................................................................................... 10

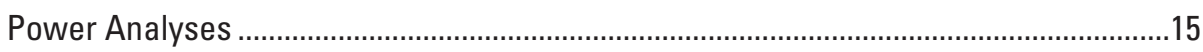

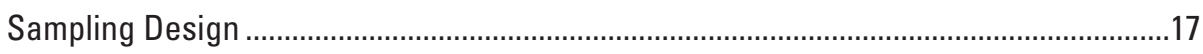

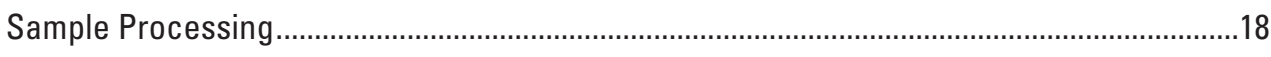

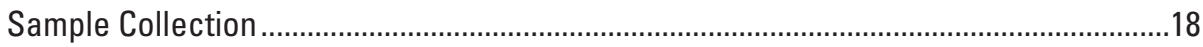

Macroinvertebrate Density, Biomass, and Energy Estimations.......................................20

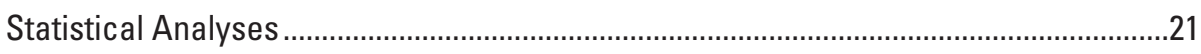

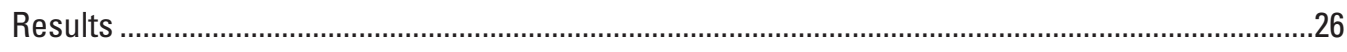

Salinity, Elevation, and Sediment Characteristics Among Sites...........................................26

Within-Site Macroinvertebrate Community Composition, Density, Biomass, and

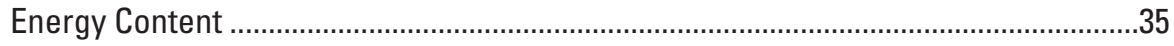

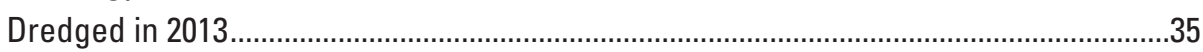

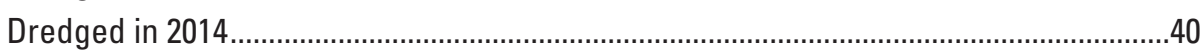

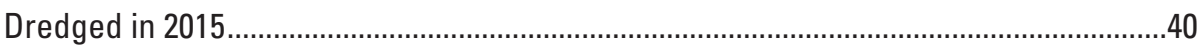

The Effect of Dredging on Macroinvertebrate Density, Biomass, and Energy Content..........45

The Effect of Distance and Time on Macroinvertebrate Density, Biomass and

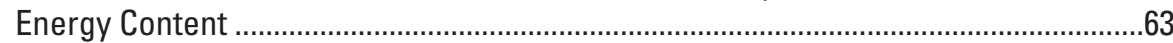

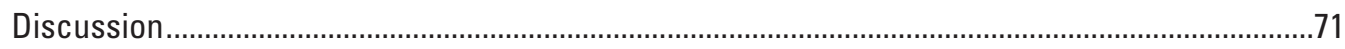

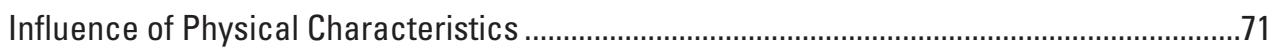

The Effect of Dredging on Trophic Support for Target Fishes .................................................72

The of Effects of Distance and Time ................................................................................

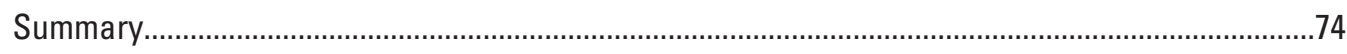

References Cited

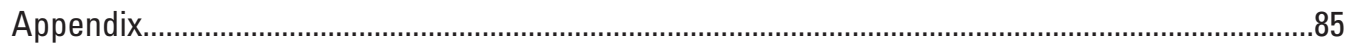




\section{Figures}

1. Diagram showing the Benthic Resource Assessment Technique outlines the activities to relate the resource value of benthic macroinvertebrates to fish predators.

2. Graph showing mean density of benthic macroinvertebrates by 2-centimeter depth increments at dredged and undredged reference areas sampled at Mooring Road and Pier 32 sites during the pilot study......

3. Conceptual diagram illustrating differences in prey consumption for focal foraging fish species, and between juvenile and adult fish

4. Map of study sites in central San Francisco Bay.

5. Map of sampling locations in the Dumbarton Shoals mudflat adjacent to pond RSF2 in the Ravenswood complex of the South Bay Salt Pond Restoration Project......12

6. Map of San Francisco Bay benthic assemblages.

7. Image showing Paradise Cay Homeowners Association study site composed of residential docks and berths in western San Francisco Bay.....

8. Image showing Strawberry Channel study site composed of residential docks and berths in dredged channel through residential area and Aramburu Island in Richardson Bay

9. Image showing Richardson Bay Marina study site composed of marina docks and an undredged reference area northeast of the marina.

10. Image showing Port of San Francisco Pier 32 study site composed of an area between piers 32 and 36 in San Francisco

11. Image showing Mooring Road study site composed of dredged areas around residential docks in tidally influenced San Rafael Creek

12. Image showing Loch Lomond Marina study site composed of a marina and entrance channel in San Rafael Bay sampled as part of the full study.

13. Image showing Paradise Cay Yacht Harbor study site composed of a marina and entrance channel in western San Francisco Bay.

14. Graphs showing power analysis curves for individual taxa groups based on the comprehensive U.S. Geological Survey Dumbarton macroinvertebrate dataset.

15. Graphs showing power analysis curves for individual taxa groups based on the 2015 pilot study macroinvertebrate dataset

16. Bar graph showing summer and winter demersal salinity at six coring sites during four sampling periods.

17. Bar graph showing elevation in dredged and undredged areas at six study sites .........28

18. Bar graph showing sediment organic matter content measured as percent loss on ignition in shallow and deep cores of dredged and undredged areas at six study sites in San Francisco Bay

19. Bar graph showing percent silt in sediments from shallow and deep cores of dredged and undredged areas at six study sites in San Francisco Bay.....

20. Bar graphs showing percent sand in sediments from shallow and deep cores of dredged and undredged areas at six study sites in San Francisco Bay......

21. Bar graph showing percent clay in sediments from shallow and deep cores of dredged and undredged areas at six study sites in San Francisco Bay.

22. Bar graph showing sediment $\mathrm{pH}$ measured in shallow and deep cores of dredged and undredged areas at six study sites in San Francisco Bay. 
23. Sediment triangles used to classify sediment texture with percent sand, percent silt, and percent clay from sediments collected in dredged and undredged areas at six study sites in San Francisco Bay.

24. Graph showing mean densities of macroinvertebrate taxa in dredged and undredged areas at seven sites in San Francisco Bay .. .41

25. Graph showing mean biomass of macroinvertebrate taxa in dredged and undredged areas at six sites in San Francisco Bay.....

26. Graph showing mean energy of macroinvertebrate taxa in dredged and undredged areas at six sites in San Francisco Bay.....

27. Graph showing mean densities of macroinvertebrate taxa collected in dredged and undredged areas at five pilot study sites in November 2015

28. Graph showing mean densities of macroinvertebrate taxa collected in dredged and undredged areas at six study sites in August 2016

29. Graph showing mean densities of macroinvertebrate taxa collected in dredged and undredged areas at six study sites in January 2017

30. Graph showing mean densities of macroinvertebrate taxa collected in dredged and undredged areas at six study sites in August 2017.

31. Graph showing mean density of macroinvertebrate taxa from different size classes in shallow cores from dredged and undredged areas at six study sites in San Francisco Bay.

32. Graph showing mean density of macroinvertebrate taxa from different size classes in deep cores from dredged and undredged areas at six study sites in San Francisco Bay.

33. Graph showing mean biomass of macroinvertebrate taxa collected in dredged and undredged areas at six study sites in August 2016

34. Graph showing mean biomass of macroinvertebrate taxa collected in dredged and undredged areas at six study sites in January 2017

35. Graph showing mean biomass of macroinvertebrate taxa collected in dredged and undredged areas at six study sites in August 2017

36. Graph showing mean biomass of macroinvertebrate taxa from different size classes in shallow cores from dredged and undredged areas at six study sites in San Francisco Bay.

37. Graph showing mean biomass of macroinvertebrate taxa from different size classes in deep cores from dredged and undredged areas at six study sites in San Francisco Bay.

38. Graph showing mean energy of macroinvertebrate taxa collected in dredged and undredged areas at six study sites in August 2016.

39. Graph showing mean energy of macroinvertebrate taxa collected in dredged and undredged areas at six study sites in January 2017

40. Graph showing mean energy of macroinvertebrate taxa collected in dredged and undredged areas at six study sites in August 2017

41. Graph showing mean energy of macroinvertebrate taxa from different size classes in shallow cores from dredged and undredged areas at six study sites in San Francisco Bay ....

42. Graph showing mean energy of macroinvertebrate taxa from different size classes in deep cores from dredged and undredged areas at six study sites in San Francisco Bay.

43. Graph showing change in macroinvertebrate density by size class in shallow and whole core fractions with increasing distance from a dredged area...... 
44. Graph showing change in macroinvertebrate biomass by size class in shallow and whole core fractions with increasing distance from a dredged area

45. Graph showing change in macroinvertebrate energy by size class in shallow and whole core fractions with increasing distance from a dredged area .67

46. Graph showing change in macroinvertebrate density by size class in shallow and whole core fractions with increasing time since a site was dredged

47. Graph showing change in macroinvertebrate biomass by size class in shallow and whole core fractions with increasing time since a site was dredged.

48. Graph showing change in macroinvertebrate energy by size class in shallow and whole core fractions with increasing time since a site was dredged.

\section{Tables}

1. Foraging depth, common macroinvertebrate prey, foraging mode, and prey size class for focal fish species juveniles and adults.

2. Simplified foraging table for focal fish species showing the depth increments and prey class sizes used in the MBRAT assessment

3. Central Bay site selection table indicating all sites considered for the pilot and full study.

4. Sampling scenarios used in simulation power analyses to determine project sample size

5. GLM results for demersal salinity as a function of site and sampling period ..................26

6. GLM results for core elevation as a function of site....................................................26

7. Macroinvertebrate taxa identified in shallow cores from dredged and undredged locations at six sites in San Francisco Bay, California .36

8. Macroinvertebrate taxa identified in deep cores from dredged and undredged locations at six sites in San Francisco Bay, California.

9. Comparison of mean macroinvertebrate density, biomass in dry weight, and energy in dredged and undredged areas during the pilot and full study in each site ....44

10. Summary of GLMM results for total density of macroinvertebrates from different size classes found in shallow and deep cores at six sites with dredged and undredged areas

11. Summary of GLMM results for total biomass of macroinvertebrates from different size classes found in shallow and deep cores at six sites within dredged and undredged areas.

12. Summary of GLMM results for total energy of macroinvertebrates from different size classes found in shallow and deep cores at six sites within dredged and undredged areas.

13. Summary of GLMM results testing the effects of distance from dredged areas, season, salinity, and elevation on total density of macroinvertebrates from different size classes found in shallow and deep cores at six sites.

14. Summary of GLMM results testing the effects of distance to nearest dredged areas, season, salinity, and elevation on total biomass of macroinvertebrates from different size classes found in shallow and deep cores at six sites.

15. Summary of GLMM results testing the effects of distance from dredged areas, season, salinity, and elevation on total energy of macroinvertebrates from different size classes found in shallow and deep cores at six sites. 
16. Summary of GLMM results testing the effects of time-since-dredged, season, salinity, and elevation on total density of macroinvertebrates from different size classes found in shallow and deep cores at six sites.

17. Summary of GLMM results testing the effects of time since dredged, season, salinity, and elevation on total biomass of macroinvertebrates from different size classes found in shallow and deep cores at six sites.

18. Summary of GLMM results testing the effects of time since dredged, season, salinity, and elevation on total energy of macroinvertebrates from different size classes found in shallow and deep cores at six sites.

\section{Conversion Factors}

International System of Units to U.S. customary units

\begin{tabular}{|c|c|c|}
\hline Multiply & By & To obtain \\
\hline \multicolumn{3}{|c|}{ Length } \\
\hline micrometer $(\mu \mathrm{m})$ & 0.0004279515 & inch (in) \\
\hline centimeter $(\mathrm{cm})$ & 0.3937 & inch (in) \\
\hline millimeter (mm) & 0.03937 & inch (in) \\
\hline meter (m) & 3.281 & foot $(\mathrm{ft})$ \\
\hline kilometer $(\mathrm{km})$ & 0.6214 & mile (mi) \\
\hline kilometer $(\mathrm{km})$ & 0.5400 & mile, nautical (nmi) \\
\hline meter (m) & 1.094 & yard (yd) \\
\hline \multicolumn{3}{|c|}{ Area } \\
\hline square meter $\left(\mathrm{m}^{2}\right)$ & 0.0002471 & acre \\
\hline square kilometer $\left(\mathrm{km}^{2}\right)$ & 247.1 & acre \\
\hline square meter $\left(\mathrm{m}^{2}\right)$ & 10.76 & square foot $\left(\mathrm{ft}^{2}\right)$ \\
\hline square kilometer $\left(\mathrm{km}^{2}\right)$ & 0.3861 & square mile $\left(\mathrm{mi}^{2}\right)$ \\
\hline \multicolumn{3}{|c|}{ Mass } \\
\hline $\operatorname{gram}(\mathrm{g})$ & 0.03527 & ounce, avoirdupois (oz) \\
\hline \multicolumn{3}{|c|}{ Energy } \\
\hline joule $(\mathrm{J})$ & 0.2388459 & calorie (cal) \\
\hline kilojoules (kJ) & 238.8459 & Calorie (cal) \\
\hline
\end{tabular}

Temperature in degrees Celsius $\left({ }^{\circ} \mathrm{C}\right)$ may be converted to degrees Fahrenheit $\left({ }^{\circ} \mathrm{F}\right)$ as follows:

$$
{ }^{\circ} \mathrm{F}=\left(1.8 \times{ }^{\circ} \mathrm{C}\right)+32 .
$$

\section{Datum}

Vertical coordinate information is referenced to the North American Vertical Datum of 1988 (NAVD 88).

Elevation, as used in this report, refers to distance above the vertical datum. 


\section{Abbreviations}

\begin{tabular}{ll} 
AFDM & ash-free dry mass \\
AIC & Akaike's Information Criterion \\
BACI & Before After Control Impact \\
BRAT & Benthic Resources Assessment Technique \\
${ }^{\circ}$ C & degree Celsius \\
dw & dry weight \\
EFH & Essential Fish Habitat \\
EPA & Environmental Protection Agency \\
ESA & Endangered Species Act \\
FMP & Fishery Management Plan \\
GLM & General Linear Models \\
GLMM & Generalized Linear Mixed Models \\
HEP & Habitat Evaluation Program \\
HOA & Homeowners Association \\
LDF & Linear Discriminant Function \\
LTMS & Long Term Management Strategy \\
MBRAT & Modified Benthic Resources Assessment Technique \\
MLLW & mean lower low water \\
MSA & Magnuson-Stevens Fishery Conservation and Management Act \\
NMFS & National Marine Fisheries Service \\
ppt & parts per thousand \\
psu & practical salinity units \\
SFB & San Francisco Bay \\
SFRWOCB & San Francisco Regional Water Quality Control Board \\
U.S.A. & United States of America \\
USACE & U.S. Army Corps of Engineers \\
USFWS & U.S. Fish and Wildlife Service \\
USGS & U.S. Geological Survey \\
\hline M &
\end{tabular}




\title{
Impacts of Periodic Dredging on Macroinvertebrate Prey Availability for Benthic Foraging Fishes in Central San Francisco Bay, California
}

\author{
By Susan E.W. De La Cruz, ${ }^{1}$ Isa Woo, ${ }^{1}$ Laurie Hall, 1 Alison Flanagan, 1, 2 and Hannah Mittelstaedt1, 3
}

\section{Background}

Because of its importance for species covered under Federal Fishery Management Plans (FMPs), the San Francisco Bay (SFB) estuary has been designated as Essential Fish Habitat (EFH) under the Magnuson-Stevens Fishery Conservation and Management Act (MSA; 16 United States Code $\$ 18559$ b). Within this estuary, benthic macroinvertebrate communities provide important prey resources for many economically significant fish species that rely on EFH. Periodic maintenance dredging can impact benthic communities; however, there is a lack of scientific information specific to SFB regarding dredging effects on macroinvertebrates in fish foraging areas. In addition, rates of benthic community recolonization and recovery following dredging and subsequent effects on foraging fish are unknown. For this reason, it is difficult for regulatory and resource agencies to determine the impacts of maintenance dredging. Thus, the National Marine Fisheries Service (NMFS) and the consortium of agencies (U.S. Environmental Protection Agency [EPA], U.S. Army Corp of Engineers [USACE], San Francisco Regional Water Quality Control Board [SFRWQCB], and San Francisco Bay Conservation and Development Commission [BCDC]) that make up the San Francisco Bay Long Term Management Strategy for Dredging (LTMS) identified a study of dredging impacts on SFB fish foraging habitat as one of their highest priorities in their 2011 Programmatic EFH Agreement (U.S. Army Corp of Engineers and U.S. Environmental Protection Agency, 2011).

The LTMS agencies identified the region of interest as shallow $(<13$ feet $[<4$ meters $(\mathrm{m})]$ mean lower low water [MLLW]), soft-bottom (silt/clay soil texture) areas in the Central Bay of SFB that were periodically dredged (every $1-3$ years). Fish species of interest were compiled by NMFS and included those managed by the Pacific Groundfish, Pacific Salmon, and Coastal Pelagic FMPs (pursuant to the MSA) as well as those listed under the California State or Federal

1U.S. Geological Survey.

${ }^{2}$ San Diego Zoo Global.

${ }^{3}$ University of Maine.
Endangered Species Act (ESA; 16 U.S.C. §1531-1544) as threatened or endangered. Target species included leopard shark (Triakis semifasciata), big skate (Raja binoculata), English sole (Parophrys vetulus), starry flounder (Platichthys stellatus), brown rockfish (Sebastes auriculatus), green sturgeon (Acipenser medirostris; threatened species under Federal ESA), northern anchovy (Engraulis mordax), longfin smelt (Spirinchus thaleichthys, threatened under California ESA), and Pacific sardine (Sardinops sagax). In addition, Dungeness crab (Cancer magister), California halibut (Paralichthys californicus), and white sturgeon (Acipenser transmontanus) also were included because they are substantial contributors to the California State fishery.

To address LTMS priorities, U.S. Geological Survey, Western Ecological Research Center, San Francisco Bay Estuary Field Station (hereafter USGS) conducted a multi-phased project including an initial literature review, study design, pilot study, and implementation of a full study. The overarching goal was to assess the effects of periodic dredge operations (every 1-3 years) on benthic habitat for foraging fish in the Central Bay, with emphasis on the foraging requirements of target fish species and analyses of benthic macroinvertebrates in dredged areas compared to adjacent undredged reference areas. The USGS partnered with University of California, Davis, fisheries expert James Hobbs to synthesize existing knowledge of fish foraging ecology and review benthic infauna community composition in SFB with a focus on the Central Bay. The literature review (Phase I; De La Cruz and others, 2016) addressed key questions identified by the LTMS on benthic foraging fish in the study area, including the following: (1) What are target fish eating? (2) What are the seasonal differences in prey items and macroinvertebrate assemblages? (3) What are the annual differences in prey items and macroinvertebrate assemblages? (4) What are the predominant macroinvertebrate functional groups from the perspective of fish foraging? Phase II consisted of creating a framework for a functional assessment of maintenance dredging effects on foraging fish and drafting a full study design (De La Cruz and others, 2017), which was then tested in the Phase III pilot study. The Phase IV full study incorporated lessons learned from the pilot study. Here we focus on the results of the full study and implications for benthic foraging fishes. 


\section{Introduction}

San Francisco Bay, the largest estuary on the Pacific coast of North America, has been greatly modified by human development for commercial, residential, and recreational purposes (Nichols and others, 1986; Cohen and Carlton, 1998). Despite this urban estuary's extensive history of habitat alteration, SFB remains home to myriad wildlife and continues to provide essential ecosystem functions through its role as a nursery, maturation area, and foraging habitat for many fishes including several state and Federal ESA-listed species (for example, longfin smelt, winter and spring-run Chinook salmon [Oncorhynchus tshawytscha], and green sturgeon) and species of economic importance (Dungeness crab, California halibut, and white sturgeon). Furthermore, SFB has been designated as EFH in the Pacific Groundfish, Pacific Salmon, and Coastal Pelagic FMPs pursuant to the MSA.

In urbanized estuaries, dredging (the action of removing benthic sediment) is often necessary at varying intervals and intensities to maintain access to shallow-water facilities such as marinas, harbors, and navigational channels. Though periodic and recurring dredge activities may be necessary to maintain waterway access, the impacts of maintenance dredging on fish habitat are largely unknown. Dredging is a localized disturbance that can adversely impact benthic communities either directly by the removal of organisms (via mortality or injury by entrainment, impingement, or burial; Hirsch and others, 1978; Nightingale and Simenstad, 2001) or indirectly by reducing habitat quality (for example, releasing buried organic matter, nutrients, or contaminants, and increasing suspended sediment concentrations; Reilly and others, 1992; Newell and others, 1998; Ray, 2005). Maintenance dredging may also indirectly impact benthic communities by increasing predation risk and (or) facilitating the colonization of opportunistic non-native or invasive species (Hanson and others, 2004). These physical changes can have cascading impacts on benthic communities (for example, altered composition and species abundance) and subsequently on fishes that forage on benthic infauna (Hirsch and others, 1978; LaSalle, 1990; Clarke and others, 2000; Dernie and others, 2003; Lebednik, 2004; Ray and others, 2005; Rich, 2010).

\section{Fish Foraging Ecology}

Shallow subtidal and intertidal benthos are key foraging areas for many fish species. Knowledge of fish diets and prey accessibility (including, prey burial depth, prey size class) are fundamental to understanding the foraging value of the benthos for demersal fishes. Specific data about diets and prey sizes of fishes are generally lacking for SFB (De La Cruz and others, 2016), and much of the limited existing information on macroinvertebrate prey is at a broad taxonomic level (for example, crustaceans). Many of the target fish species for this study are considered generalist foragers that consume a wide variety of organisms depending on species-specific physiological constraints (such as, gape size, maximum foraging depth) and life history traits that can often change from juvenile to adult life (ontogenic) stages (De La Cruz and others, 2016; table 1). For example, leopard sharks and big skates are opportunistic generalists known to forage on benthic macroinvertebrates (such as, crabs, molluscs, shrimp, polychaetes), and as they grow, they tend to consume other fish (Hart, 1973; Talent, 1976; Motta and Wilga, 2001; Ebert and Ebert, 2005; Yang, 2007). Whereas juvenile green and white sturgeon consume opossum shrimp and amphipods (Radtke, 1966; Muir and others, 1988), adults consume a wider range of macroinvertebrates and fishes (Adams and others, 2002). Within estuaries, smaller California halibut use shallow habitats and have a predominantly macroinvertebrate-based diet but switch to a more fish-based diet as they grow and inhabit deeper channels (Allen, 1988). Pelagic fishes, including northern anchovy and Pacific sardine, exhibit two distinct modes of feeding: particulate feeding (individual prey items are attacked and consumed) and filter feeding (small food particles are collected and strained through the fine filaments in the gill rakers; Blaxter and Hunter, 1982). In some species, adults will actively switch between particulate and filter feeding modes depending on prey availability. Larval and young juvenile smelt primarily feed on calanoid copepods, including Eurytemora affinis (Baxter and others, 1999) and other crustaceans, and mature juveniles and adult fish feed predominantly on opossum shrimp (Neomysis mercedis, Acanthomysis sp.) and copepods (Feyrer and others, 2003; Hobbs and others, 2006).

The relative abundance of adult and juvenile fish in the Central Bay varies seasonally and by species (De La Cruz and others, 2016). For instance, juvenile northern anchovy are present year-round, but adults are absent during winter. Juvenile Pacific herring (Clupea pallasii) are abundant throughout SFB in spring and summer, whereas adult herring are more abundant in winter when they spawn on substrates such as eelgrass and wharf pilings (Skinner, 1962). California halibut of varying age classes are abundant throughout winter, spring, early summer, and fall, with fewer individuals collected in mid-summer months (California Department of Fish and Wildlife, 2013). Young leopard sharks are abundant year-round in SFB and spend many years maturing in SFB before migrating offshore to reproduce (Ebert and Ebert, 2005).

The foraging value of the shallow benthos for generalist fishes can be evaluated using the metric of prey profitability, which compares the energy gained to the energy expended to capture and ingest prey. Prey profitability has been used to evaluate habitat quality and carrying capacity for many benthic foraging predators (Godin and Keenleyside, 1984). The energy content and accessibility (prey size in relation to fish gape size, and the vertical distribution in the sediment) of macroinvertebrates are integral to determining their availability to benthic foraging fishes (Piet and others, 1998; van Denderen and others, 2013). 
Table 1. Foraging depth, common macroinvertebrate prey, foraging mode, and prey size class for focal fish species juveniles and adults.

[Information was obtained during the Phase I Literature Review and from local expert opinion ${ }^{1}$. Abbreviaitons: mm, millimeter; $<$, less than; cm, centimeter]

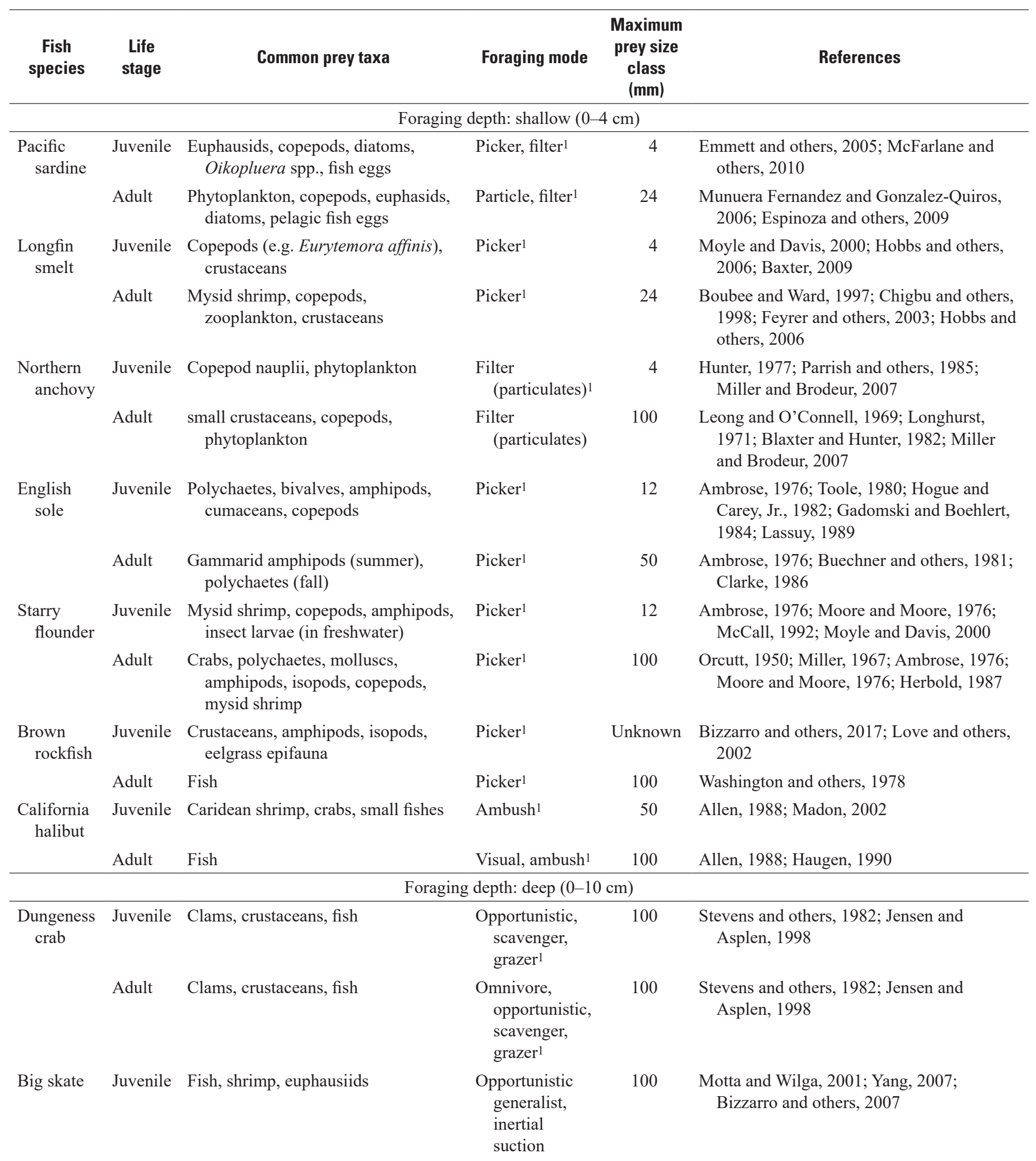


Table 1. Foraging depth, common macroinvertebrate prey, foraging mode, and prey size class for focal fish species juveniles and adults.-Continued

[Information was obtained during the Phase I Literature Review and from local expert opinion ${ }^{1}$. Abbreviaitons: mm, millimeter; $<$, less than; cm, centimeter]

\begin{tabular}{|c|c|c|c|c|c|}
\hline $\begin{array}{l}\text { Fish } \\
\text { species }\end{array}$ & $\begin{array}{l}\text { Life } \\
\text { stage }\end{array}$ & Common prey taxa & Foraging mode & $\begin{array}{l}\text { Maximum } \\
\text { prey size } \\
\text { class } \\
(\mathrm{mm})\end{array}$ & References \\
\hline & Adult & $\begin{array}{l}\text { Crabs, cephalopods, demersal } \\
\text { teleosts, shrimps, polychaetes, } \\
\text { clams, sculpin, pelagic skate }\end{array}$ & $\begin{array}{l}\text { Opportunistic } \\
\text { generalist }\end{array}$ & 100 & $\begin{array}{l}\text { Ackerman, 1971; Russo, 1975; Talent, 1976; } \\
\text { Kao, 2000; Robinson and others, 2007; } \\
\text { Yang, 2007; Bizzarro and others, 2007; } \\
\text { Reecht and others, } 2013\end{array}$ \\
\hline $\begin{array}{l}\text { Green } \\
\quad \text { sturgeon }\end{array}$ & Adult & $\begin{array}{l}\text { Shrimp, molluscs, amphipods, small } \\
\text { fish }\end{array}$ & $\begin{array}{l}\text { Opportunistic, } \\
\text { suction }\end{array}$ & 100 & $\begin{array}{l}\text { Adams and others, 2002; Moyle, 2002; } \\
\text { Dumbauld and others, } 2008\end{array}$ \\
\hline $\begin{array}{l}\text { White } \\
\text { sturgeon }\end{array}$ & Adult & $\begin{array}{l}\text { Shrimp, crabs, clams, herring, } \\
\text { anchovy, striped bass, starry } \\
\text { flounder, smelt, herring eggs }\end{array}$ & Suction & 100 & $\begin{array}{l}\text { McKechnie and Fenner, 1971; Miller, 2004; } \\
\text { Dumbauld and others, } 2008\end{array}$ \\
\hline \multirow[t]{2}{*}{$\begin{array}{c}\text { Leopard } \\
\text { shark }\end{array}$} & Juvenile & Crabs (e.g. Hemigrapsus oregonensis) & $\begin{array}{l}\text { Opportunistic } \\
\text { generalist, } \\
\text { disturb mud, } \\
\text { inertial } \\
\text { suction }\end{array}$ & 100 & $\begin{array}{l}\text { Talent, 1976; Barry, 1983; Barry and others, } \\
\text { 1996; Ferry-Graham, 1998; Motta and } \\
\text { Wilga, } 2001\end{array}$ \\
\hline & Adult & $\begin{array}{l}\text { Fishes, crabs, clam siphons, } \\
\text { innkeeper worms (e.g. Urechis } \\
\text { caupo), fish eggs (e,g, Atherinopsis } \\
\text { californiensis), isopods, } \\
\text { amphipods, zooplankton, shrimp, } \\
\text { teleosts, small elasmobranch }\end{array}$ & $\begin{array}{l}\text { Opportunistic } \\
\text { generalist, } \\
\text { disturb mud, } \\
\text { inertial } \\
\text { suction }\end{array}$ & 100 & $\begin{array}{l}\text { Talent, 1976; Barry, 1983; Barry and others, } \\
\text { 1996; Motta and Wilga, 2001; Stewart and } \\
\text { others, 2004; Ebert and Ebert, } 2005\end{array}$ \\
\hline
\end{tabular}

${ }^{1}$ Expert opinion, James Hobbs, University of California, Davis.

\section{Macroinvertebrate Prey Availability}

Benthic and epibenthic macroinvertebrates are important prey resources for fish, birds, and other predators. Benthic infauna also form an interface between sediment properties and the aquatic food web by facilitating nutrient flux through their burrowing and feeding activities within the sediment (Nichols and Pamatmat, 1988; Thompson and others, 2000; Weigelhofer and Waringer, 2003; Cardoso and others, 2010). Benthic macroinvertebrate communities in SFB commonly include gastropods, bivalves, polychaetes, oligochaetes, and several crustaceans (such as., amphipods, isopods, copepods, crabs, mysids and shrimp; Thompson and others, 2007, 2013).
The distribution and community composition of benthic infauna is largely controlled by salinity (Nichols and Pamatmat, 1988). In winter months, during periods of high freshwater input, the surface salinity in the Central Bay can rapidly decline from 30 to 10 parts per thousand (ppt); however, salinity values in the demersal waters tend to be more stable owing to stratification of the less dense surface freshwater (Cloern and others, 2000). Because salinity in the Central Bay is more stable than in the northern reaches of SFB, it sustains a more diverse community across seasons (Thompson and others, 2000). Still, large freshwater influx in the Central Bay can affect the benthos in shallow shoal areas (Thompson and others, 2007). 
Although benthic macroinvertebrate communities are most influenced by salinity gradients within SFB, macroinvertebrate abundance, taxonomic richness, and spatial distributions are also influenced by other physical factors such as temperature, flow velocities, and substrate characteristics (for example, texture and particle size; Thompson and others, 2000). In shallow shoals, sediment composition and particle size are largely influenced by physical processes such as wave action and water flow velocity (Krone, 1979; van Duren and Middelburg, 2001). Benthic habitats with greater proportions of fine particles such as silt and clay contain different macroinvertebrate species than coarser sediments such as sand and shell fragments, resulting in distinct benthic community assemblages.

Much of the benthic substrate throughout the Central Bay consists of a mixture of sand, silt, clay, and shell fragments (Goals Project, 1999; California State Coastal Conservancy, 2010; Barnard and others, 2013; Greene and others, 2013); however, the shallow benthic regions that are the focus of this study are characterized predominately by muddy, fine-grained sediment substrates, which are dominated by amphipods (primarily Ampelisca abdita as well as Monocorophium acherusicum) and mobile errant polychaetes (primarily Euchone limnicola; Thompson and others, 2000; Lee II and others, 2003). Benthic macroinvertebrate density and taxonomic richness are frequently greater in these low-flow habitats with fine sediments, whereas sandy substrates with swift-moving currents are typically dominated by polychaete species (Heteropodarke heteromorpha and E. limnicola; Thompson and others, 2000, 2007; Lee II and others, 2003).

\section{Assessing Benthic Recovery After Maintenance Dredging}

In urbanized estuaries, maintenance dredging and resulting localized disturbances often occur at regular or periodic intervals to maintain access to harbors, marinas, and waterways. Benthic recovery post-dredging is complicated by the fact that repopulation may occur at different rates for different taxa. In general, large, hard-bodied macroinvertebrates with greater longevity have longer recovery times and are disproportionately affected by disturbance. Smaller species are often associated with high fecundity and shorter generation times and thus are conceivably more resilient to disturbance (McCall, 1977; Newell and others, 1998; van Denderen and others, 2013). Recolonization is primarily driven by the lateral movement of organisms, larval settlement, and appropriate conditions for larval settlement and growth. Initial colonizers are generally opportunistic species that may differ from those that were present prior to sediment removal (Oliver and others, 1977; Newell and others, 1998; Applied Marine Sciences Inc., 2009; Cohen, 2010). Following disturbance, a transitional community with lower peak abundances than the initial colonizers will appear, but it may take several years for larger and longer-lived taxa to recolonize and grow (McCall, 1977;
Van Der Veer and others, 1985; Rhoads and Germano, 1986; Newell and others, 1998). Thus, chronic disturbance may change a community of large, hard-bodied macroinvertebrates to one that is dominated by smaller, soft-bodied species (such as, polychaetes) with low species diversity (Rhoads and Germano, 1986; Rees and Dare, 1993; Newell and others, 1998; van Denderen and others, 2013). On the other hand, some studies indicate that with enough time, the re-established biotic community might recover and resemble the pre-dredged community (Oliver and others, 1977; Newell and others, 1998; Applied Marine Sciences Inc., 2009; Cohen, 2010).

Defining benthic recovery remains a major challenge, despite the post-dredging impact studies that have been conducted over the past several decades. Several methods have been suggested for evaluating recovery, but there is little consensus concerning the appropriate metrics (such as, macroinvertebrate density, biomass, species richness, evenness, and diversity) or statistical techniques to assess post-disturbance recovery (Rhoads and Germano, 1986; Bolam and Rees, 2003; Wilber and Clarke, 2007; Wilber and others, 2008). As a result, recovery estimates are variable (Bolam and others, 2006; Wilber and Clarke, 2007). Recovery is often defined as a return to a baseline (pre-impact) or reference (unimpacted) condition and tested for using a BACI (Before-After Control-Impact; Currie and Parry, 1996; Wilber and others, 2008) or Beyond BACI (an asymmetrical BACI design using multiple reference sites to assess impacts; Underwood, 1994; Roberts and others, 1998a, 1998b) design. The combination of natural and anthropogenic disturbances is common in estuaries such that the baseline macroinvertebrate community (in other words, pre-dredging) may not be representative of a natural, "healthy" community, and instead may be dominated by a few small, opportunistic taxa commonly found in areas that are frequently or chronically disturbed. Newell and others (1998) examined 17 studies and reported that recovery rates were faster in disturbed and channel mud habitat communities that originally comprised small opportunistic taxa. They noted that habitats that were originally dominated by larger, long-lived taxa had much slower recovery times (up to 12 years).

Structural metrics such as the density and taxonomic composition of benthic organisms at a site are often used to assess benthic recovery; however, they may not be very meaningful if they lack relationships to ecological functions of interest in the impacted habitat (Wilber and Clarke, 2007), such as prey productivity for consumers. Measures of ecological function, such as macroinvertebrate biomass, secondary production (amount of energy generated by a species assemblage; Brey and others, 1988), and functional diversity (for example, presence of multiple foraging guilds) of the community, provide information on the role benthic macroinvertebrates play in the ecosystem and may recover independently from structural metrics (Bolam, 2012, 2014). Thus, there is a growing interest in applying structural and functional metrics to evaluate recovery of habitat quality after a disturbance event (Clarke and others, 1993; Rodil and others, 2013; Bolam, 2014). 


\section{Measuring Structural and Functional Recovery}

Assessments such as the U.S. Fish and Wildlife Service (USFWS) Habitat Evaluation Procedure (HEP; U.S. Fish and Wildlife Service, 1980), Estuarine Habitat Assessment Protocol (Simenstad and others, 1991), and the Benthic Resources Assessment Technique (BRAT; Lunz and Kendall, 1982; LaSalle, 1990) have been developed and used to evaluate functional recovery of the benthos. The BRAT assessment was specifically developed by the USACE to be used as a quantitative tool for evaluating and comparing dredge impacted sites in terms of trophic support for bottom feeding fishes (Lunz and Kendall, 1982; LaSalle, 1990). The BRAT approach has traditionally been used to determine the most suitable location to dispose of dredge material (Lunz and Kendall, 1982; Clarke, 1986), and it has also been applied to assessments of benthic prey availability for fish (Rhoads and Germano, 1986). Because BRAT integrates information on fish foraging ecology, prey biomass and energy content to estimate trophic (nutritional) support available for fishes in benthic habitats, we applied this framework with modifications to evaluate the impacts of periodic dredging on benthic communities compared to undredged reference areas. Our study considered the foraging needs of target fish species that were identified under the 2011 Programmatic EFH Agreement. In addition, we evaluated benthic macroinvertebrate density and community taxonomic composition between dredged and undredged reference areas as structural measures of habitat. Here we present synthesized results from the full study evaluating habitat quality for SFB benthic foraging fish in relationship to (1) dredged versus undredged locations, (2) distance to dredged site, and (3) years since dredging.

\section{Methods}

\section{Study Design}

\section{Modified Benthic Resources Assessment Technique (MBRAT) Framework}

The BRAT framework (fig. 1) integrates information on fish foraging ecology and prey profitability to estimate the energy that is available to specific fish feeding guilds. Prey profitability is a measurement that has been used to evaluate habitat quality for many benthic foraging predators (Richman and Lovvorn, 2004; Goss-Custard and others, 2006; Lovvorn and others, 2013), including fish (Crowder and Cooper, 1982; Godin and Keenleyside, 1984). Energy content, size, and accessibility (visibility, vertical distribution in the sediment, predator defense, and escape capabilities) of macroinvertebrates are integral to determining their profitability to benthic foraging fish (Lunz and Kendall, 1982; Piet and others, 1998; van Denderen and others, 2013).

We modified the BRAT framework to address our study objectives, budget, and scope. This modified BRAT (hereafter, MBRAT) approach used benthic fish foraging ecology and diet information identified in our literature review and by local expert opinion (table 1; De La Cruz and others, 2017), in lieu of conducting a fish diet study. For each focal fish species, we considered the following factors for juveniles and adults: common prey taxa, foraging mode, foraging depth in the benthic subsurface, and maximum prey size (tables 1-2). Many benthic-foraging fishes are generalists, and consumption of macroinvertebrate prey items is related to local macroinvertebrate prey density, biomass, and vertical distribution. Therefore, we adjusted the MBRAT to include sorting and identifying macroinvertebrates into broad taxonomic categories instead of identifying to lowest taxonomic unit possible. Clarke (1986) found that similar modifications to broad levels of taxonomic identification were sufficient for BRAT in previous studies. However, we identified macroinvertebrates to species or lowest taxonomic unit in a random subset of core samples from each study site to enable comparison of structural metrics across sites.

Another modification to the traditional BRAT approach was dividing benthic core samples into two depths: shallow $(0-4$ centimeters $[\mathrm{cm}])$ and deep $(4-10 \mathrm{~cm})$, rather than partitioning in $2-\mathrm{cm}$ increments. This modification was based on our pilot study where we found that the majority of macroinvertebrates in cores from two pilot sites were located in the upper $4 \mathrm{~cm}$ of the core (fig. 2; De La Cruz and others, 2017). Furthermore, other studies of fish prey have identified the best sample depth as that which approximately matches the predator's foraging depth (Ferraro and Cole, 2004). Although skates, sturgeon, leopard sharks, and crabs can forage relatively deep within the sediment (here represented as the entire core 0-10 cm depth), other target fish in our study (such as, sardine, anchovy, brown rockfish, and others) are primarily epi-benthic and near-surface feeders, which corresponds to the shallow portion of our cores $(0-4 \mathrm{~cm}$ depth; Gotshall, 1977; Holland and others, 1980; Bottom and Jones, 1990; tables 1-2). Thus, in our simplified scheme for evaluating prey accessibility (table 2), the upper $0-4 \mathrm{~cm}$ of the core represents the foraging area of target species such as sardine, anchovy, and brown rockfish, whereas deeper $(4-10 \mathrm{~cm})$ portions of the core represent the additional area available to species such as skates, sturgeon, leopard sharks, and crabs (table 2). 


\section{BENTHIC RESOURCES ASSESSMENT \\ TECHNIQUE \\ ( BRAT )}

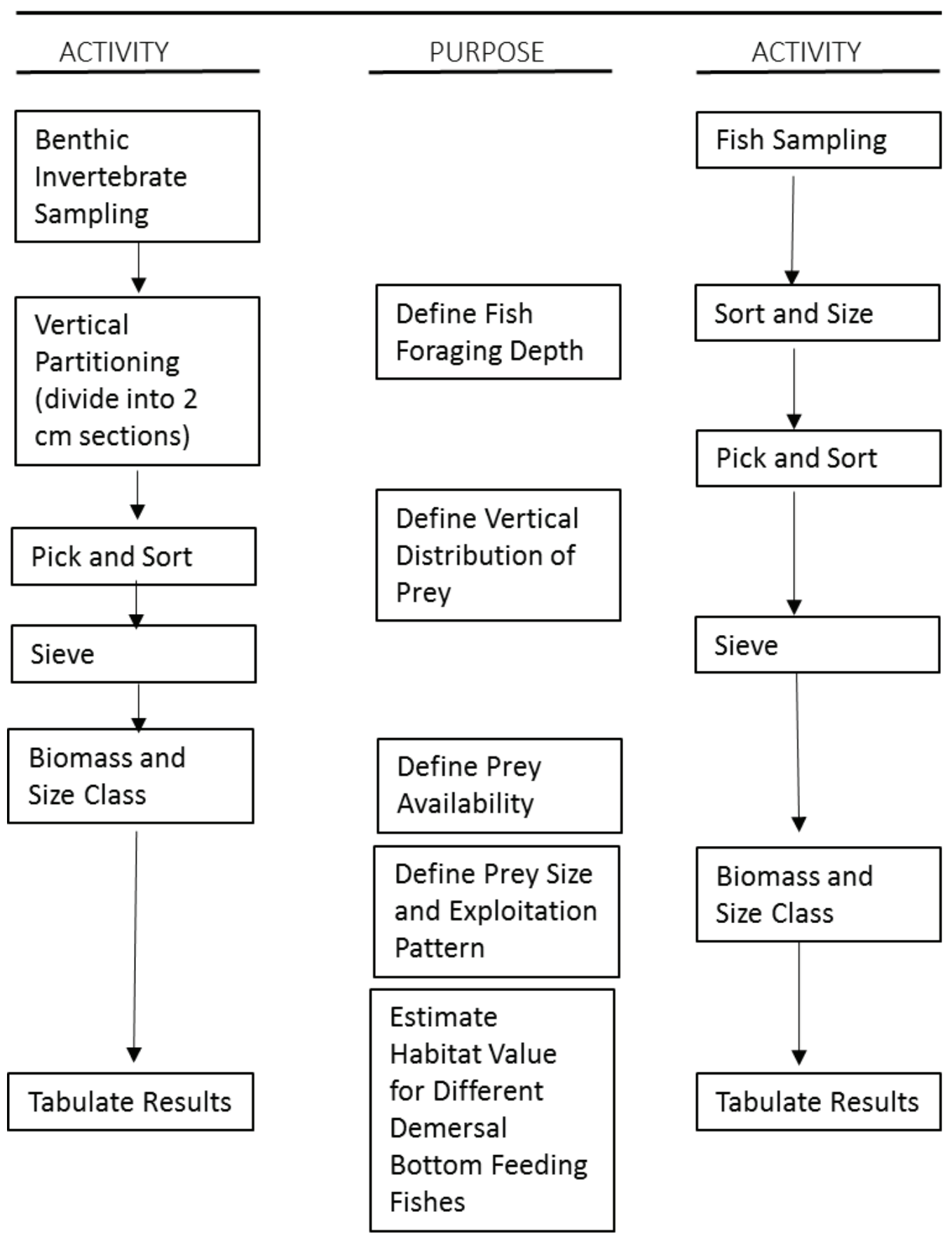

Figure 1. The Benthic Resource Assessment Technique (BRAT) outlines the activities to relate the resource value of benthic macroinvertebrates to fish predators (modified from Rhoads and Germano, 1986). 
Table 2. Simplified foraging table for focal fish species showing the depth increments and prey class sizes used in the MBRAT assessment.

[Depth and size class categories were derived based on information discussed in the Phase I Literature Review and summarized in table 3. Estimated available mean biomass (gram per square meter; $\mathrm{g} / \mathrm{m}^{2}$ ) in dry weight $\left(\mathrm{dw}\right.$ ) and energy (kilojoule per square meter; $\mathrm{kJ} / \mathrm{m}^{2}$ ) for each fish species and age class were calculated across all study sites and sampling dates for the appropriate depth and prey size class. *The 50-100 millimeter ( $\mathrm{mm}$ ) size class can be consumed by some fish species; however, this study did not detect any macroinvertebrates in the 50-100 mm size class. Abbreviations: \%, percent; cm, centimeter]

\begin{tabular}{|c|c|c|c|c|c|c|c|c|}
\hline \multirow{2}{*}{ Fish species } & \multirow{2}{*}{$\begin{array}{l}\text { Life } \\
\text { stage }\end{array}$} & \multirow{2}{*}{$\begin{array}{l}\text { Prey size } \\
\text { class } \\
(\mathrm{mm})^{*}\end{array}$} & \multicolumn{2}{|c|}{$\begin{array}{c}\text { Available prey } \\
\text { biomass (g/m² dw) }\end{array}$} & \multirow{2}{*}{$\begin{array}{l}\% \text { biomass } \\
\text { reduction from } \\
\text { undredged to } \\
\text { dredged }\end{array}$} & \multicolumn{2}{|c|}{$\begin{array}{l}\text { Available prey } \\
\text { energy }\left(\mathbf{k J} / \mathbf{m}^{2}\right)\end{array}$} & \multirow{2}{*}{$\begin{array}{l}\% \text { energy } \\
\text { reduction from } \\
\text { undredged to } \\
\text { dredged }\end{array}$} \\
\hline & & & Dredged & Undredged & & Dredged & Undredged & \\
\hline \multicolumn{9}{|c|}{ Foraging depth in sediment: Shallow $(0-4 \mathrm{~cm})$} \\
\hline \multirow[t]{2}{*}{ Pacific sardine } & Juvenile & $0-4$ & 3.04 & 5.40 & 44 & 50.23 & 89.22 & 44 \\
\hline & Adult & $0-24$ & 26.62 & 41.02 & 35 & 126.96 & 212.43 & 40 \\
\hline \multirow[t]{2}{*}{ Longfin smelt } & Juvenile & $0-4$ & 3.04 & 5.40 & 44 & 50.23 & 89.22 & 44 \\
\hline & Adult & $0-24$ & 26.62 & 41.02 & 35 & 126.96 & 212.43 & 40 \\
\hline \multirow[t]{2}{*}{ Northern anchovy } & Juvenile & $0-4$ & 3.04 & 5.40 & 44 & 50.23 & 89.22 & 44 \\
\hline & Adult & $0-100$ & 30.04 & 48.86 & 39 & 137.99 & 237.46 & 42 \\
\hline \multirow[t]{2}{*}{ English sole } & Juvenile & $0-12$ & 5.95 & 12.05 & 51 & 60.02 & 112.94 & 47 \\
\hline & Adult & $0-50$ & 30.04 & 48.86 & 39 & 126.96 & 212.43 & 40 \\
\hline \multirow[t]{2}{*}{ Starry flounder } & Juvenile & $0-12$ & 5.95 & 12.05 & 51 & 60.02 & 112.94 & 47 \\
\hline & Adult & $0-100$ & 30.04 & 48.86 & 39 & 137.99 & 237.46 & 42 \\
\hline \multirow[t]{2}{*}{ Brown rockfish } & Juvenile & $0-4$ & 3.04 & 5.40 & 44 & 50.23 & 89.22 & 44 \\
\hline & Adult & $0-100$ & 30.04 & 48.86 & 39 & 137.99 & 237.46 & 42 \\
\hline \multirow[t]{2}{*}{ California halibut } & Juvenile & $0-50$ & 30.04 & 48.86 & 39 & 126.96 & 212.43 & 40 \\
\hline & Adult & $0-100$ & 30.04 & 48.86 & 39 & 137.99 & 237.46 & 42 \\
\hline \multicolumn{9}{|c|}{ Foraging depth in sediment: Deep $(0-10 \mathrm{~cm})$} \\
\hline \multirow[t]{2}{*}{ Dungeness crab } & Juvenile & $0-100$ & 33.44 & 56.97 & 41 & 154.66 & 310.11 & 50 \\
\hline & Adult & $0-100$ & 33.44 & 56.97 & 41 & 154.66 & 310.11 & 50 \\
\hline \multirow[t]{2}{*}{ Big skate } & Juvenile & $0-100$ & 33.44 & 56.97 & 41 & 154.66 & 310.11 & 50 \\
\hline & Adult & $0-100$ & 33.44 & 56.97 & 41 & 154.66 & 310.11 & 50 \\
\hline \multirow[t]{2}{*}{ Green sturgeon } & Juvenile & $0-100$ & 33.44 & 56.97 & 41 & 154.66 & 310.11 & 50 \\
\hline & Adult & $0-100$ & 33.44 & 56.97 & 41 & 154.66 & 310.11 & 50 \\
\hline \multirow[t]{2}{*}{ White sturgeon } & Juvenile & $0-100$ & 33.44 & 56.97 & 41 & 154.66 & 310.11 & 50 \\
\hline & Adult & $0-100$ & 33.44 & 56.97 & 41 & 154.66 & 310.11 & 50 \\
\hline \multirow[t]{2}{*}{ Leopard shark } & Juvenile & $0-100$ & 33.44 & 56.97 & 41 & 154.66 & 310.11 & 50 \\
\hline & Adult & $0-100$ & 33.44 & 56.97 & 41 & 154.66 & 310.11 & 50 \\
\hline
\end{tabular}




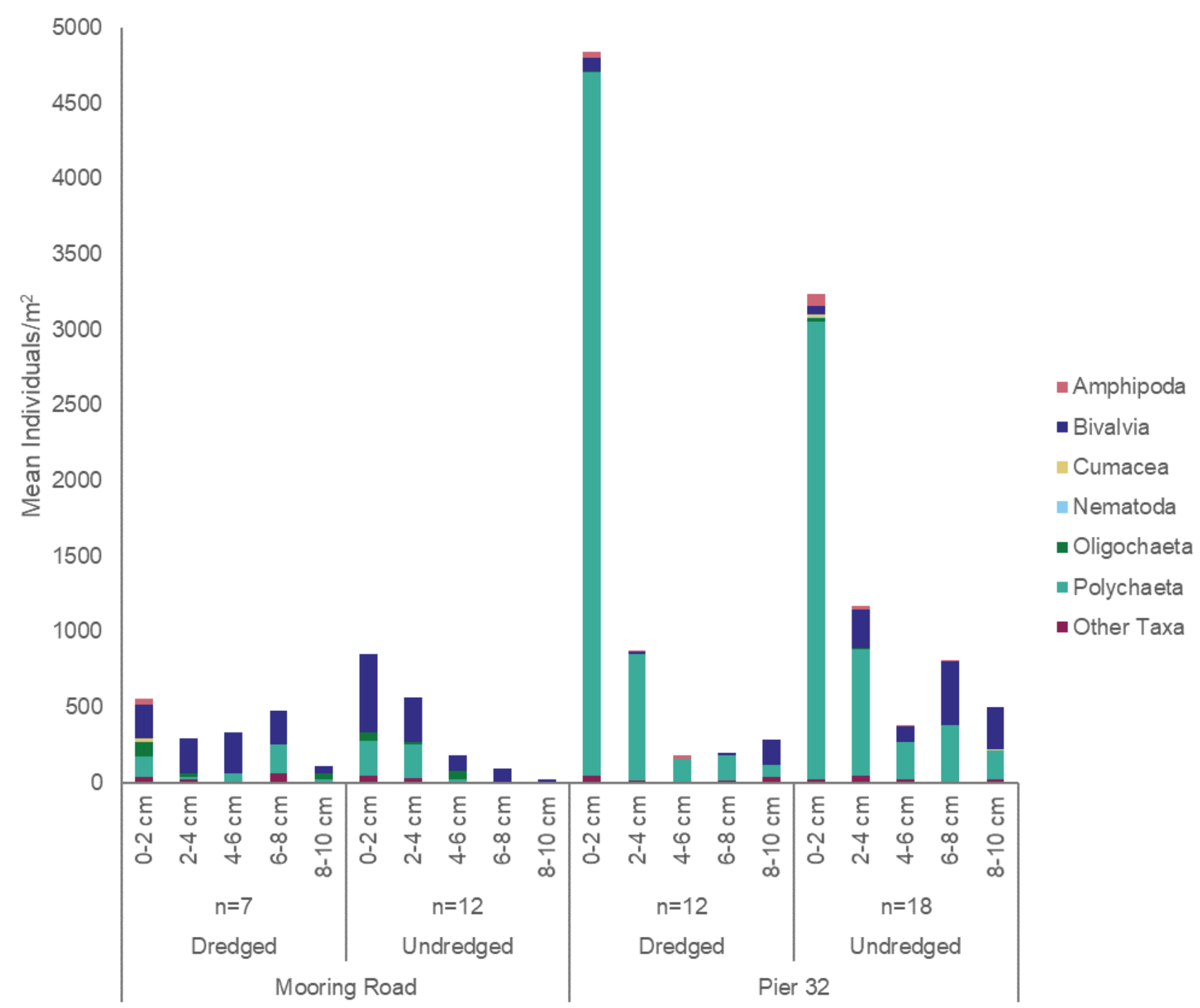

Figure 2. Mean density of benthic macroinvertebrates by 2-centimeter depth increments at dredged and undredged reference areas sampled at Mooring Road and Pier 32 sites during the pilot study.

Maximum macroinvertebrate prey sizes are largely unknown for the focal fish species in this study, especially for certain life stages (juveniles versus adults). For instance, most fish will consume different prey in juvenile compared to adult stages (such as, green and white sturgeon, California halibut; Haaker, 1975; Plummer and others, 1983; Muir and others, 1988), and spatiotemporal patterns in prey availability can induce prey switching in certain fishes (Toole, 1980; Blaxter and Hunter, 1982). While some fish are expected to be able to consume prey as large as 100 millimeters $(\mathrm{mm})$, such prey are likely to be small fishes or other highly mobile taxa, the sampling of which was outside the scope of our study. We did not encounter macroinvertebrates $>50 \mathrm{~mm}$ in our samples, even though individuals of this size can be detected with our sampling gear. Thus, after extensive literature review (De La Cruz and others, 2016) and expert consultation with Dr. James Hobbs (University of California Davis, oral and written commun., 2014, 2017), Dr. Scott Hamilton (Moss Landing Marine Laboratory, oral and written commun., 2017), and Dr. Fred Feyrer (USGS California Water Science Center, written commun., 2017), we established four unique macroinvertebrate size classes that encompassed the prey sizes that could be consumed by target fish species in our study: 0 to $4 \mathrm{~mm}$, greater than $4 \mathrm{~mm}$ to $12 \mathrm{~mm}$, greater than $12 \mathrm{~mm}$ to $24 \mathrm{~mm}$, and greater than $24 \mathrm{~mm}$ to $50 \mathrm{~mm}$ (table 2). Macroinvertebrates were sorted into size classes based on overall body length for most taxa and head width for polychaetes and oligochaetes. Diet and foraging information (prey taxa, foraging depth in sediment, and maximum prey size) for adult and juvenile focal fish species gathered during the literature review were used to evaluate macroinvertebrate prey availability for each species and life stage at each study site. 
Taken together, the components of the MBRAT method create a framework to assess density, biomass, energy content, and vertical distribution for each broad macroinvertebrate taxa group and size class and we used this information to determine prey availability for each focal fish species (fig. 3, table 2). Implicit to this framework is the idea that an increase in biomass and (or) energy content of prey (as in, trophic support) that is the right size and depth to be available for a particular target species means that there is an increase in habitat function for that species.

\section{Study Area and Site Selection}

San Francisco Bay is a shallow estuary (median depth $1.83 \mathrm{~m}$ below MLLW; Conomos and others, 1985) with four major sub-bays: Suisun Bay, North Bay (San Pablo Bay), Central Bay, and South Bay (fig. 4). We collected data for the initial power analyses conducted in this study from a 1.25 square kilometer $\left(\mathrm{km}^{2}\right)$ intertidal mudflat located in the South Bay (Dumbarton mudflat, $37^{\circ} 50^{\prime}$ N., $122^{\circ} 12^{\prime}$ W.; fig. 5). The South Bay is mesohaline (Thompson and others, 2013) with mixed semidiurnal tides ranging up to $3 \mathrm{~m}$ (Shellenbarger and others, 2013) such that the mudflat is inundated and exposed twice daily. The width of the Dumbarton mudflat increases from 200 to $900 \mathrm{~m}$ from north to south, and mudflat width is correlated with net deposition and erosion patterns throughout South Bay (van der Wegen and others, 2017). The Dumbarton mudflat extends about $1 \mathrm{~km}$ from shore to the channel and ranges in elevation from about $-1.21 \mathrm{~m}$ to $1.11 \mathrm{~m}$ North American Vertical Datum 1988 (NAVD 88). Water column salinity during flood tides at the site ranged from 18 parts per thousand (ppt) in March and April to $32 \mathrm{ppt}$ in late August and September.

Sampling sites for the pilot and full studies were located within and adjacent to marinas in the Central Bay, a predominantly polyhaline zone (1-30 ppt; fig. 6; Thompson and others, 2007, 2013; Gillet and others, 2014), which is generally characterized by fine-grained (silt and clay) to coarser sediments (sand and shell fragments; Goals Project, 1999; Subtidal Goals Project, 2010; Barnard and others, 2013; Greene and others, 2013). Selected study site marinas were all less than $4 \mathrm{~m}$ deep, and the substrate consisted mostly of silt and clay (table 3 ). Sites were also most recently dredged in 2013,2014 , or 2015 with a dredging frequency of $2-4$ years, though some sites had a longer span of time between dredging such as Strawberry Channel (7 years), Loch Lomond Marina (12 years), and Mooring Road (infrequent).

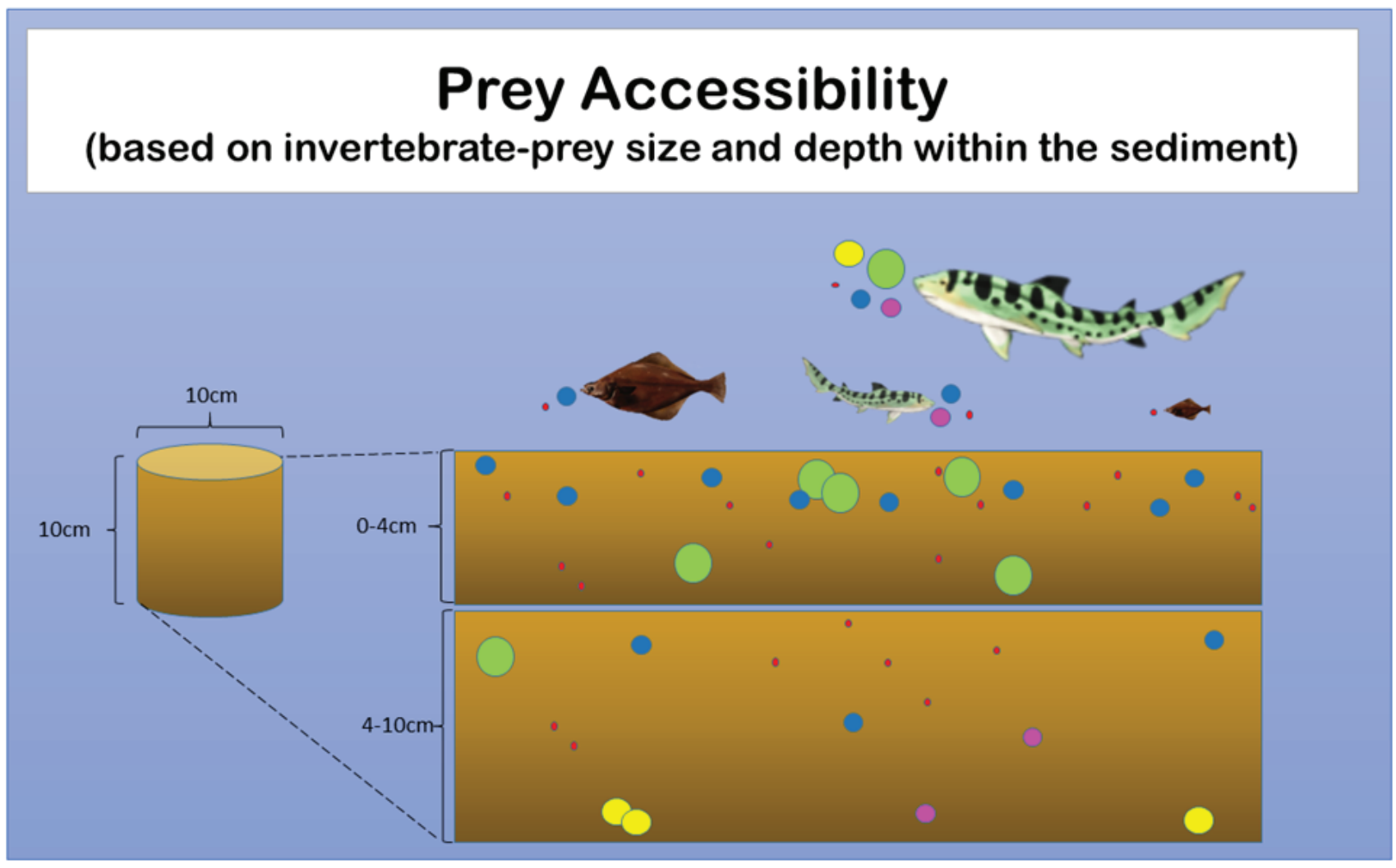

Figure 3. Conceptual diagram illustrating differences in prey consumption for focal foraging fish species and between juvenile and adult fish (for example, English sole versus a leopard shark). Expected prey accessibility is based on depth within the sediment and macroinvertebrate size. A $10-\mathrm{cm}$ sediment core is partitioned into two depth strata $(0-4 \mathrm{~cm}$ and $4-10 \mathrm{~cm})$, and different size classes of macroinvertebrates are represented by colored circles of variable dimensions. 


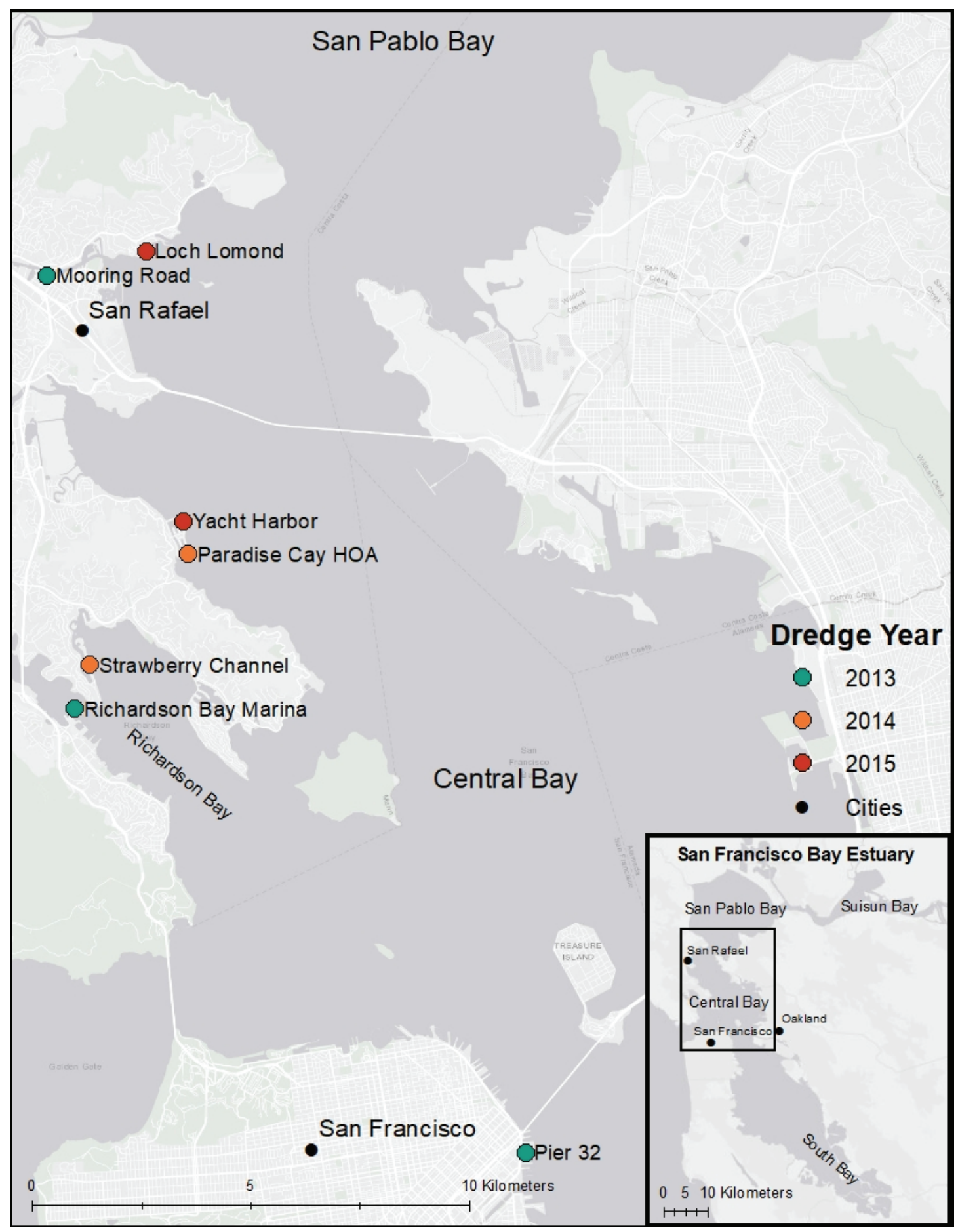

Figure 4. Study sites in central San Francisco Bay. Red sites were dredged in 2015, orange sites were dredged in 2014, and green sites were dredged in 2013. 


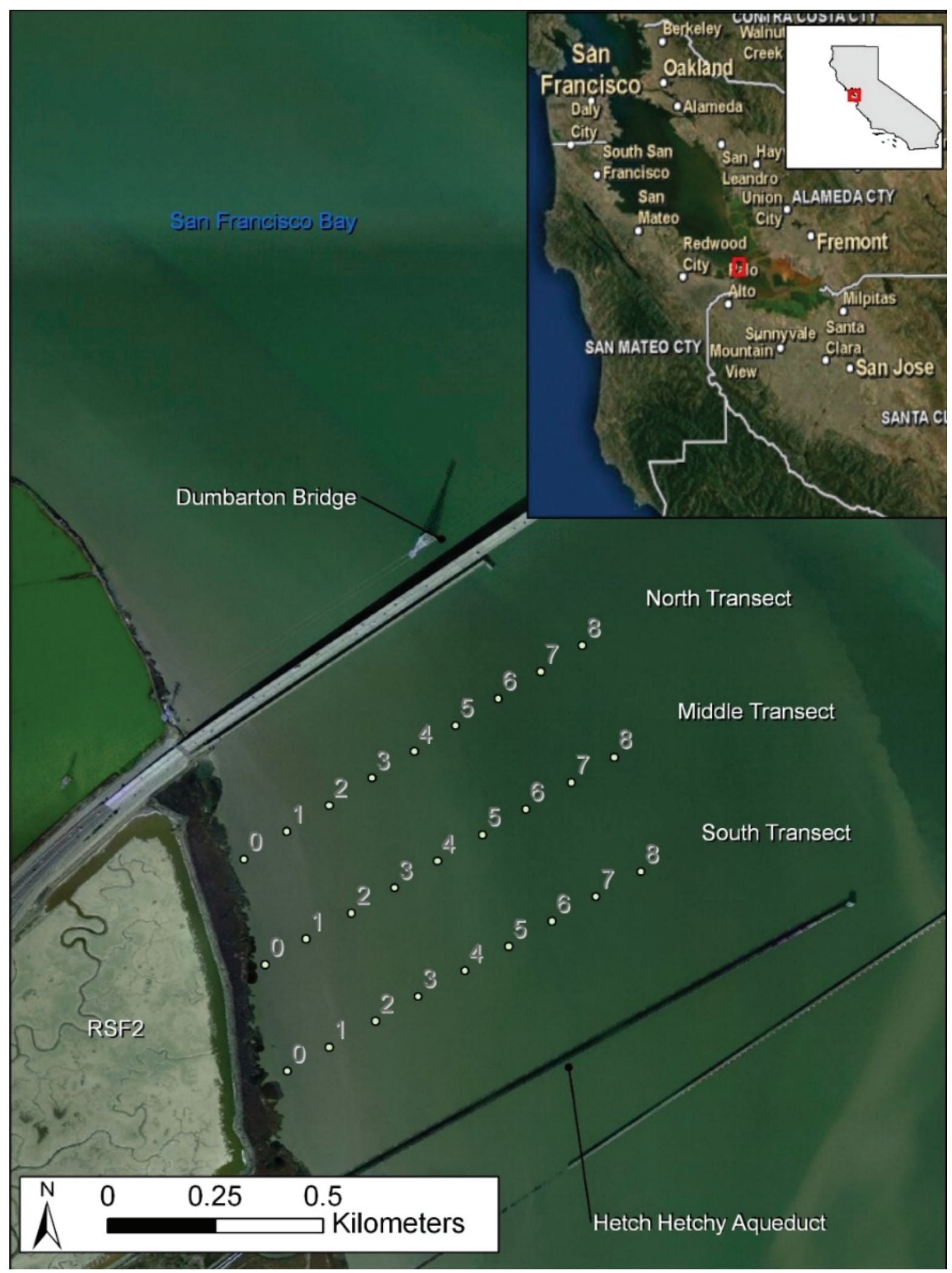

Figure 5. Sampling locations in the Dumbarton Shoals mudflat adjacent to pond RSF2 in the Ravenswood complex of the South Bay Salt Pond Restoration Project. 
Table 3. Central Bay site selection table indicating all sites considered for the pilot and full study.

[MLLW, mean lower low water; ft/m, foot per meter; SFB, San Franciso Bay; HOA, Homeowners Association]

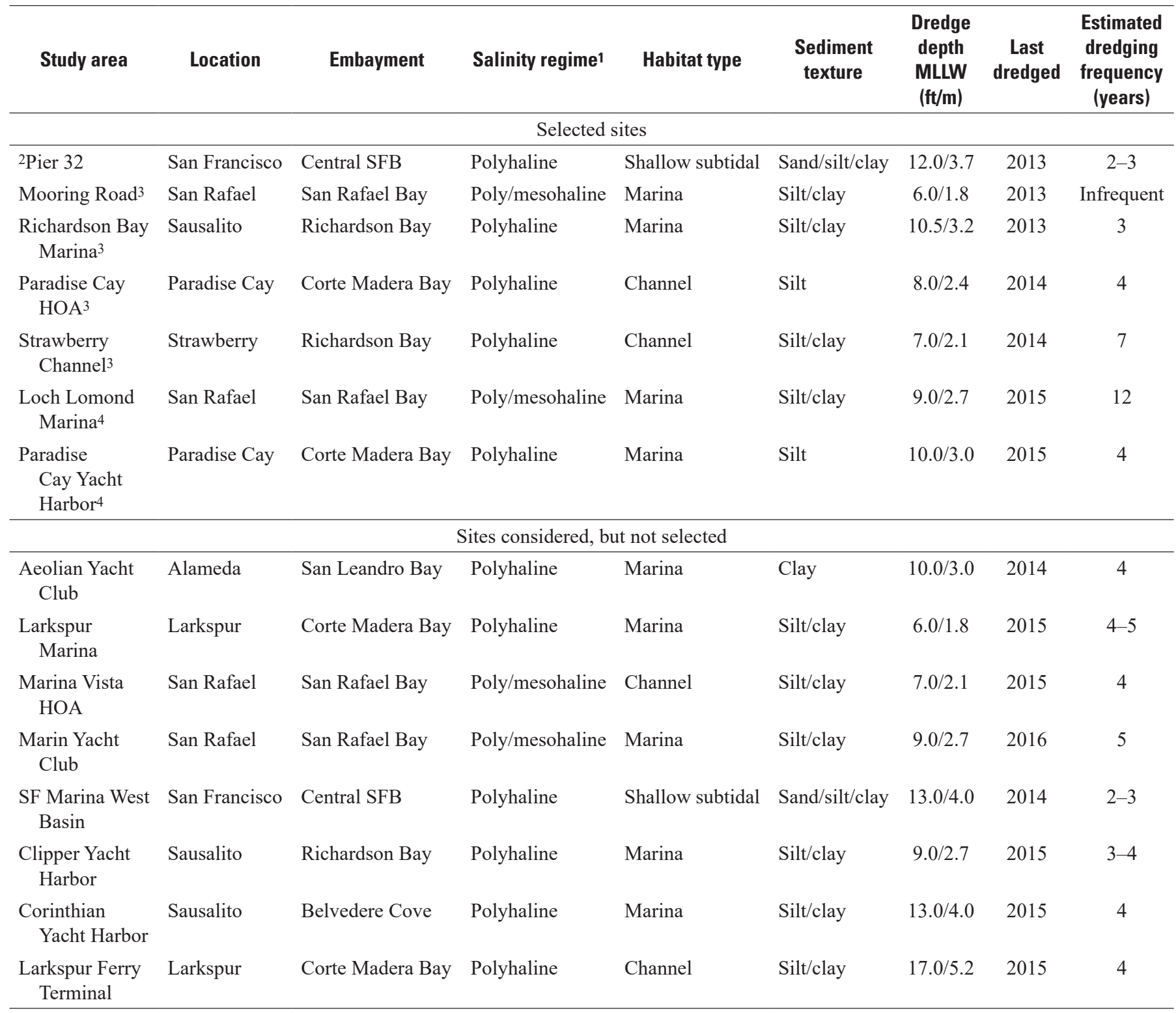

1Thompson and others, 2013.

${ }^{2}$ Sites sampled for pilot study only.

${ }^{3}$ Sites sampled for pilot study and full study.

${ }^{4}$ Sites sampled for full study only.

We selected recently dredged marinas that had adjacent corresponding undredged reference areas. Here we used the term "reference" to refer to an area that was undredged, rather than a pristine site. It is important to note that the reference areas we selected are not "undisturbed." Rather, undredged reference areas included similar localized environmental characteristics (salinity, depth, sediment texture) to the associated dredged marina, as well as ambient levels of disturbance to the sediment, including those associated with boat traffic, that are expected to occur in undredged areas of an urbanized estuary. 
We compiled site characterization information for each marina (Bay Conservation and Development Commission, unpub. data, 2015, 2016) to inform decisions about sampling design elements (table 3 ). The primary site selection criteria were based on identified project objectives and included (1) location within the polyhaline region of the Central Bay (fig. 6); (2) post-dredging depth of $<13$ feet (4 m) MLLW; (3) predominantly soft-bottom sediments; (4) a dredging date falling within one of three time periods: 1 year before present, 2 years before present, and 3 years before present; and (5) presence of an adjacent undredged reference site. Undredged reference sites were considered areas near the study marina with no record of dredging that had similar environmental conditions to their corresponding dredged area. Time since dredging categories were chosen to meet the study objective of evaluating differences in areas "that are dredged at a frequency of annually to every three years compared to those that are undredged," which was established by LTMS agencies during the study planning period.

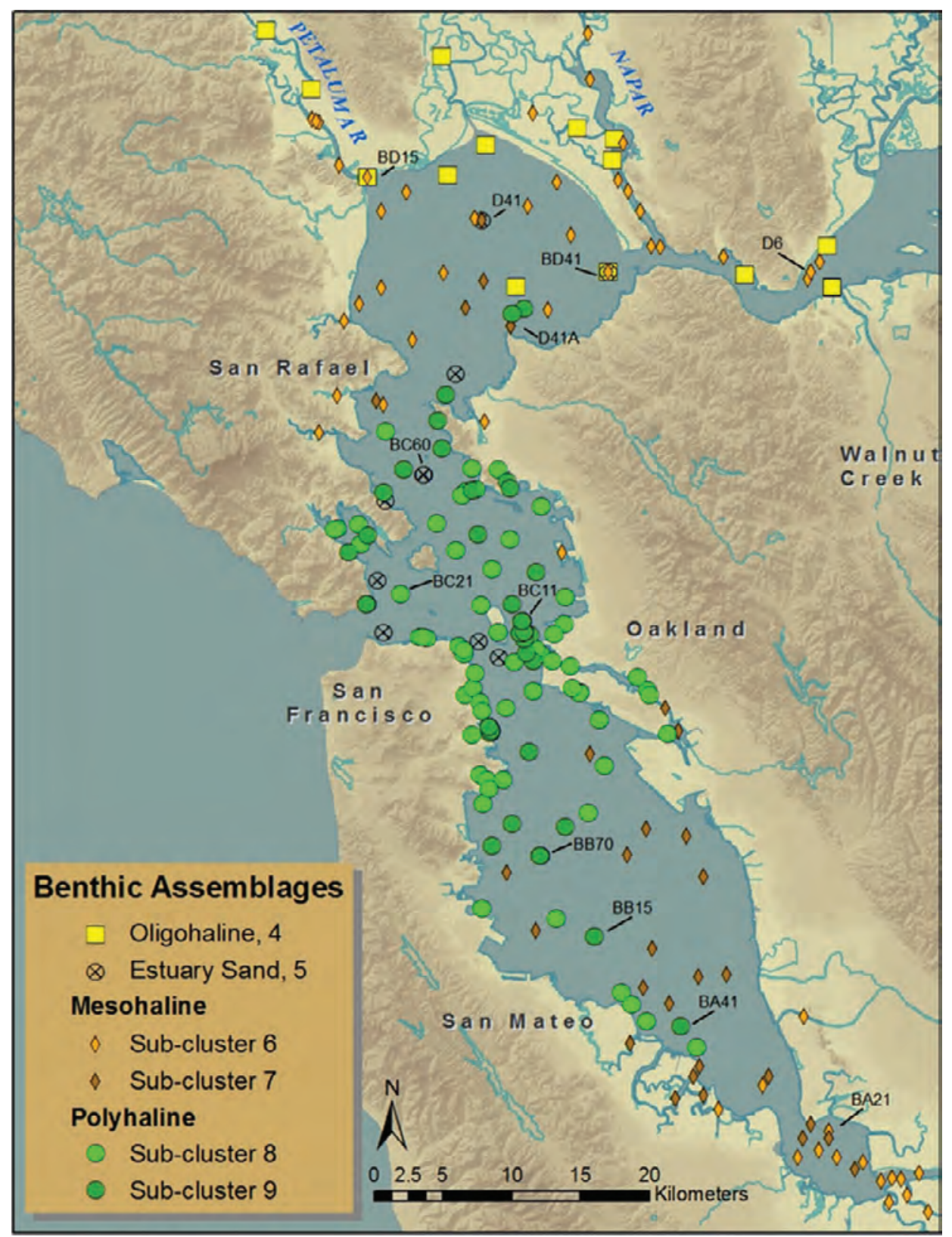

Figure 6. San Francisco Bay benthic assemblages (Thompson and others, 2013). We focused on the polyhaline benthic assemblage in Central Bay. The average salinity in this assemblage is 30.4 parts per thousand. Sub-clusters eight and nine are dominated by the amphipods, Ampelisca abdita and Monocorophium acheruscium, and sub-cluster eight has high densities of polychaetes, Mediomastus spp. and Dorvillea (Schistomeringos) annulata. 
For our pilot study, we selected sites Pier 32, Mooring Road, Richardson Bay Marina, Paradise Cay HOA, and Strawberry Channel (table 3, figs. 7-11). Pilot study samples from both the undredged and dredged areas at Pier 32 indicated the site was dominated by polychaetes, which differed from the overall community composition at the other sampling sites (De La Cruz and others, 2017). This site was also the farthest south of the five pilot sites, and although still in the polyhaline region of San Francisco Bay, may have environmental conditions that differ from sites to the north. To reduce the variability that could be related to a non-representative study site, we removed Pier 32 from our site list, retained the other pilot study sites, and added two additional sites, Loch Lomond Marina and Paradise Cay Yacht Harbor (hereafter Yacht Harbor; both dredged in 2015; figs. 12-13), for a total of six study sites for the full study. Among the six marinas chosen for the full study, there were two marinas in each of three dredging time periods: 2013, 2014, and 2015. These sites were evenly divided among three embayments within the Central Bay polyhaline region (fig. 6).

\section{Power Analyses}

After an extensive search during our Phase I literature review, we were unable to locate an appropriate existing Central Bay macroinvertebrate dataset to use in a power analysis to inform the study design. Therefore, we used a comprehensive USGS macroinvertebrate dataset collected monthly from October 2008 to April 2010 on mudflat and subtidal shoals southwest of the Dumbarton Bridge (fig. 5) as a proxy for the expected variability in the Central Bay.

We used a data-derived, simulation-based power analysis that was designed to consider variation within replicates and transects to inform the total number of transects and cores in our sampling design. In the initial step of our power analysis, we used an information-theoretic model selection framework (Akaike's information criterion [AIC]; Burnham and Anderson, 2002) to identify the most parsimonious model for each taxon. We separately modeled densities of each broad taxa group using linear mixed models (PROC Mixed, SAS 9.3, SAS Institute Inc., Cary, North Carolina, U.S.A.). We used normal approximation models where the dependent variable was the log-transformed count $(\mathrm{x}+0.5)$ for each taxon. We built the same candidate set of models for each taxon that included all possible combinations of month and year, elevation, and the interaction of these terms as fixed effects and included site, the number of transects, and the number of cores as random effects.

For each taxon, we identified the top model with the lowest AIC score and used the parameter estimates for the fixed and random effects from that model as input parameters for simulation models. Datasets were simulated for 10 different sample sizes representing different combinations of sites, transects, core locations, and core replicates (table 4). Because the Dumbarton dataset represents an undredged site with no equivalent paired dredged site, we used scenarios to simulate hypothesized macroinvertebrate reductions of 0,25 , 50 , and 75 percent owing to dredging. For each taxonomic group, we ran 1,000 simulations per sample size and reduction scenario and calculated power as the proportion of simulations in which a significant effect $(\alpha=0.05)$ was detected.

Using the data collected in our pilot study, we conducted a second power analysis to determine if the number of samples originally identified based on South Bay Dumbarton site macroinvertebrate data were appropriate for a Central Bay study given the potential differences in taxa between the two areas. We used the methods described above for the initial power analysis prior to the pilot study and updated the taxonomic groups detected in the pilot study to include Amphipoda, Bivalvia, Cumacea, Isopoda, Nematoda, Oligochaeta, and Polychaeta. We simulated datasets based on $0,25,50$, and 75 percent reduction in macroinvertebrate counts between undredged reference and dredged areas using levels of sampling variation in the pilot study.

For both power analyses, we used 80 percent power (Steidl and others, 1997; Quinn and Keough, 2002;

Di Stefano, 2003) as the minimum acceptable value for identifying a difference in macroinvertebrate density between dredged and undredged areas. In both analyses, we found that power generally increased for all taxa as the number of samples increased (figs. 14-15). In the initial analysis using the Dumbarton dataset, power to determine a 50 percent reduction in density reached $>80$ percent under the scenario containing 200 cores for all taxa except errant polychaetes, which did not reach 80 percent power until the sample size was 320 cores (fig. 14). Power to determine a 25 percent or less difference between dredged and undredged sites was low for several taxa and did not reach 80 percent power for most taxa even at a sample size of 400 cores (fig. 14).

In the second power analysis using the pilot study dataset, power to determine a 50 percent reduction in density reached $>80$ percent under the scenario containing 100 cores for all taxa except for amphipods and polychaetes, which both reached 80 percent power with a sample size of 200 cores (fig. 15). For bivalves, cumaceans, isopods, and nematodes, the power to determine a 25 percent or less difference between dredged and undredged sites reached 80 percent power with a sample size of 200 cores; however, oligochaetes only reached 80 percent under 400 -core scenarios, and amphipods and polychaetes did not reach 80 percent at any sample size (fig. 15). 


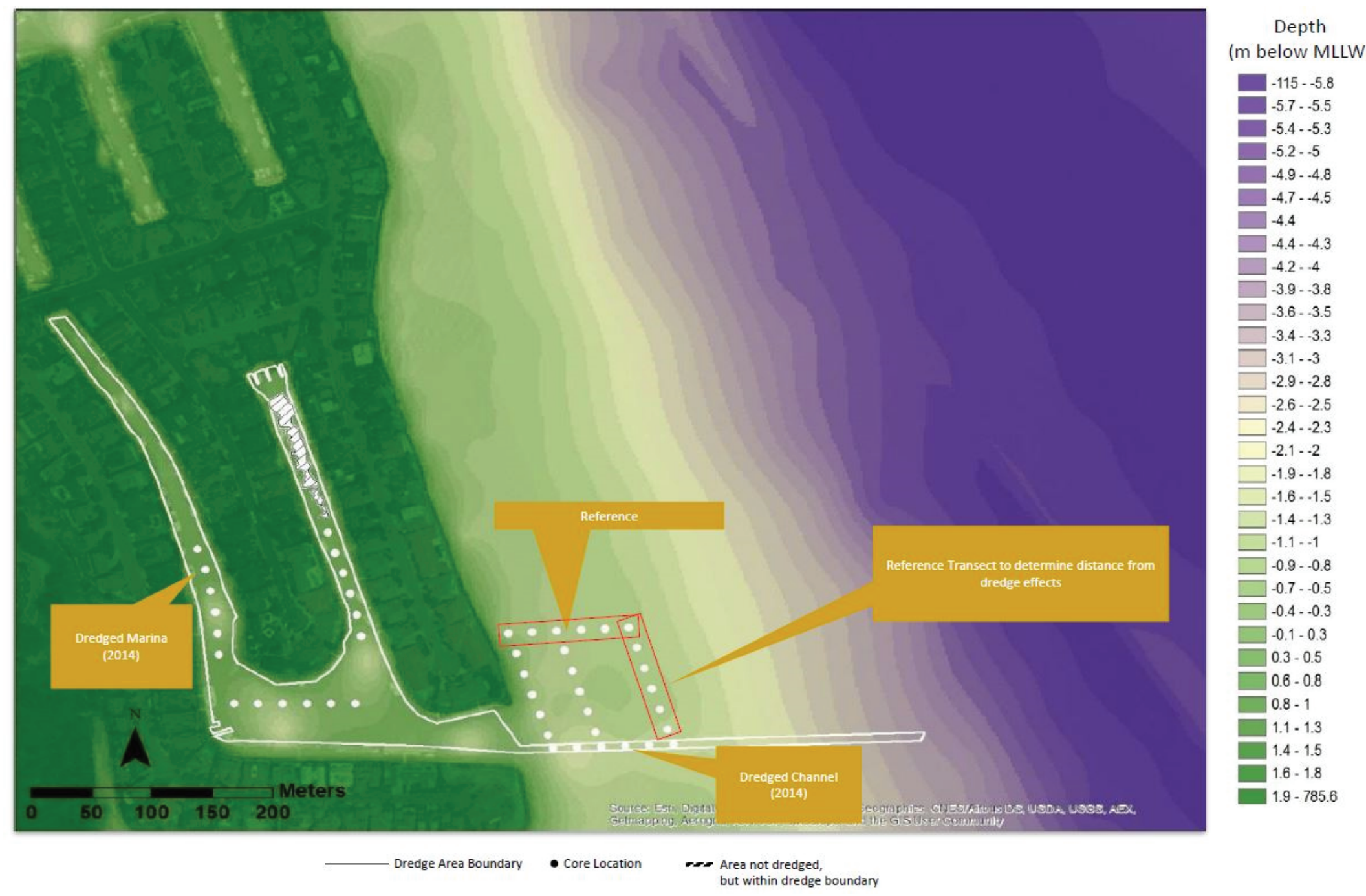

Figure 7. Paradise Cay Homeowners Association (HOA) study site composed of residential docks and berths in western San Francisco Bay. Sampled as part of the pilot and full study. The white outlined area was dredged to 8 feet mean lower low water (MLLW) in 2014. The site contains 24 core locations in the dredged area and 21 undredged reference core locations collected along 3 transects of 6 core locations in dredged marina, 1 transect of 6 core locations in dredged entrance channel, 1 reference transect of 6 core locations with 3 transects of 5 core locations extending from reference transect to dredged entrance channel transect. 


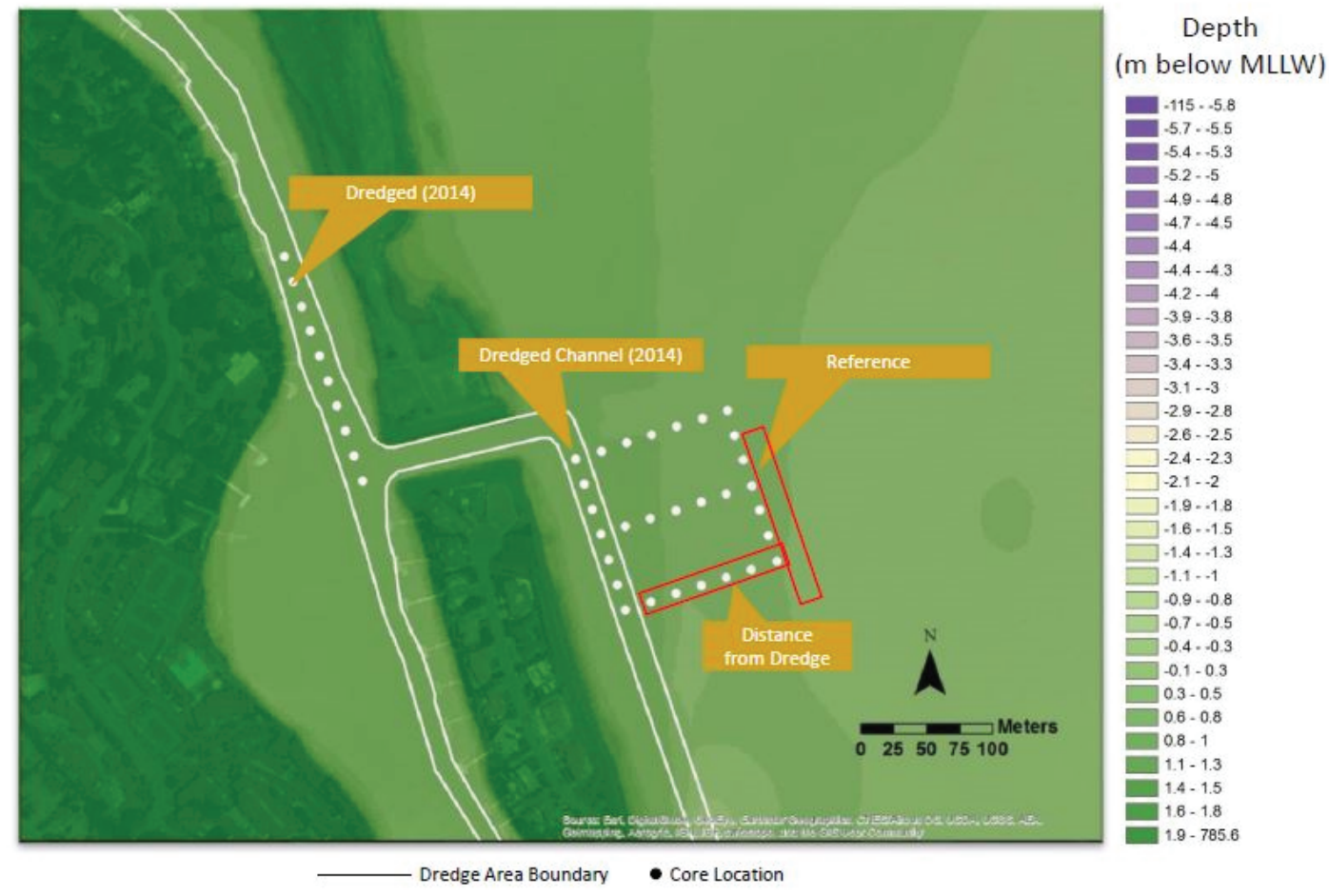

Figure 8. Strawberry Channel study site composed of residential docks and berths in dredged channel through residential area and Aramburu Island in Richardson Bay. Sampled as part of the pilot and full study. The white outlined area was dredged to 7 feet mean lower low water (MLLW) in 2014. The site contains 10 core locations in the dredged area and 12 undredged reference core locations collected along 1 transect of 10 core locations and 1 transect of 7 core locations in the dredged marina/channel, 1 reference transect of 7 core locations with 3 transects of 5 core locations extending from reference transect to dredged entrance channel transect.

\section{Sampling Design}

Given the scope and budget of the study, we determined that a design to detect a 50 percent reduction in individuals between dredged and undredged areas was most feasible. Thus, we designed the sampling effort to meet or exceed the 200-core sample size identified by the pilot data power analysis as robust for all taxonomic groups. Within each marina, we placed two to six transects in each dredged and undredged location. From each transect, we sampled a minimum of six core locations with two replicate samples taken at each core location (figs. 7-13).

Sampling was conducted seasonally in winter and summer to assess the greatest differences in seasonal variation in macroinvertebrate density and biomass. The inclusion of multiple collection periods enabled us to compare macroinvertebrate density and community composition during wet and dry seasons and across a range of seasonal salinitiesone of the major drivers of macroinvertebrate community composition (Nichols and Pamatmat, 1988; Thompson and others, 2013; De La Cruz and others, 2016). The summer sampling periods overlapped with the period of peak fish densities in the Central Bay and provided information on macroinvertebrate densities when most focal fish species were present (De La Cruz and others, 2016). To evaluate the effect of time-since-dredging on trophic support for fishes, we measured macroinvertebrate density and biomass at marinas that had been dredged 1,2, and 3 years prior to sampling. To assess the effect of distance to nearest dredge site on macroinvertebrate density and biomass, we evenly spaced sampling locations within each transect $20 \mathrm{~m}$ apart from each other and ran transects perpendicular to dredged areas so that distances up to $120 \mathrm{~m}$ away from dredged areas could be evaluated. 


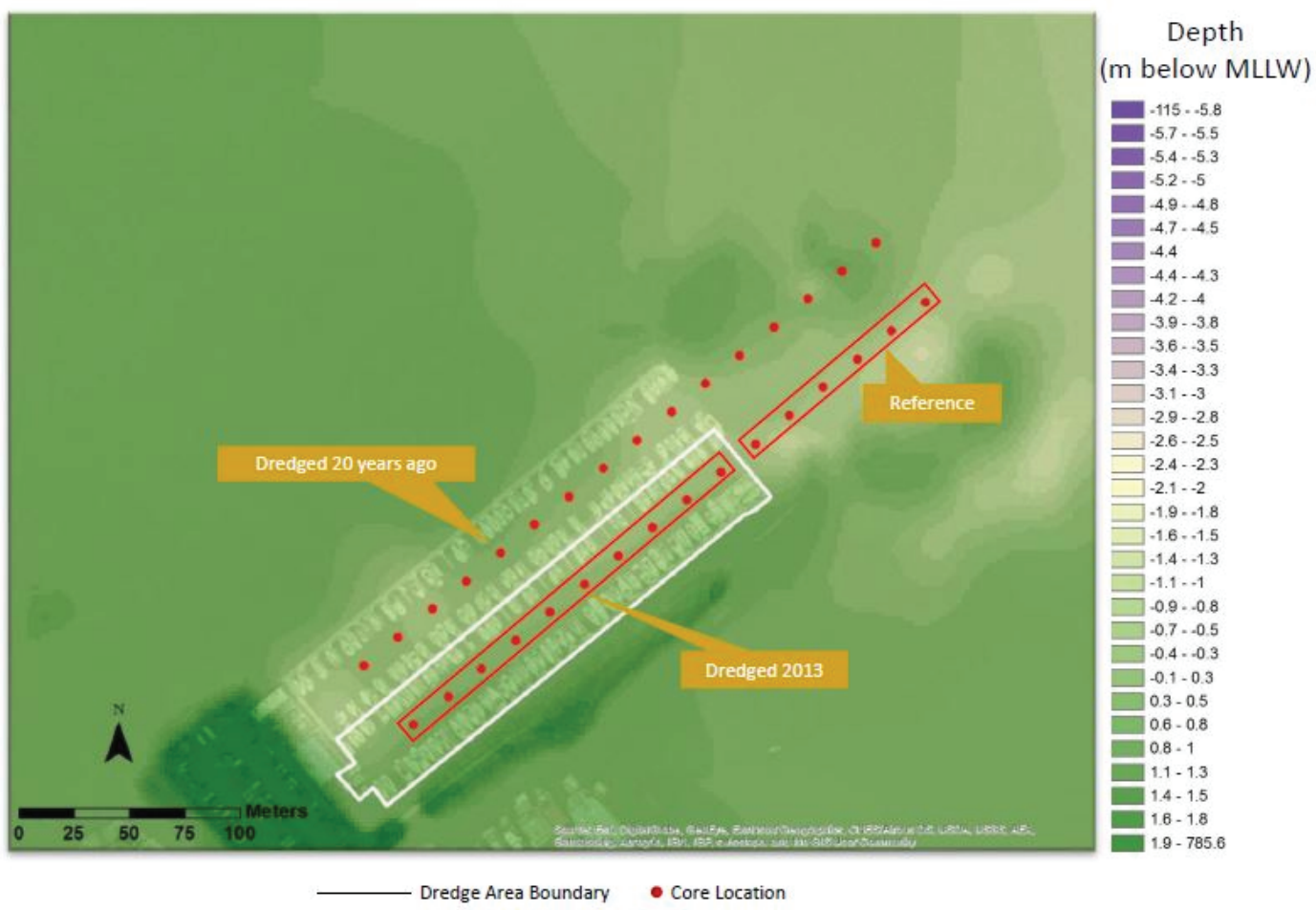

Figure 9. Richardson Bay Marina study site composed of marina docks and an undredged reference area northeast of the marina. Sampled as part of the pilot and full study. The white outlined area was dredged to 10.5 feet MLLW (mean lower low water) in 2013. The site contains one transect of 10 core locations taken in the dredged area between docks and another transect of 10 core locations in the area between docks that was dredged in 1994. Two reference transects of six core locations each extend from the marina.

\section{Sample Processing}

\section{Sample Collection}

We conducted sampling during two wet (as in, winter) and two dry (as in, summer) time periods throughout the course of the study: November 2015-December 2015 (pilot sampling), August 2016, January 2017, and August 2017. Based on our sampling design, each site had two to six transects per dredged and undredged site in a marina and a minimum of six core locations per transect. Two replicate core samples were collected at core locations set $20 \mathrm{~m}$ apart along each transect. Each core was $10 \mathrm{~cm}$ in diameter and $10 \mathrm{~cm}$ deep. Cores were systematically separated into shallow $(0-4 \mathrm{~cm})$ and deep $(4-10 \mathrm{~cm})$ increments to measure prey distribution at different depths in the sediment according to MBRAT methodology (figs. 1, 3).
Upon arrival to and departure from sampling sites, water quality (temperature, salinity, dissolved oxygen, and $\mathrm{pH}$ ) was recorded within dredged and undredged areas of each marina using a multi-parameter sonde (YSI Professional Plus, YSI, Inc., Yellow Springs, Ohio) just above the benthic surface in the demersal zone. The water depth at individual core locations along each transect was recorded using a ReefNet ${ }^{\odot}$ Sensus Ultra Depth Recorder (ReefNet, Inc., Niagra Falls, New York) attached to the coring device and corrected for MLLW tide height at the time of recording. Sediment cores were collected at the mid-point of each transect and sent to an external laboratory (AandL Western Laboratories, Modesto, California) to determine sediment grain size and chemical composition (organic matter, sediment texture, sediment $\mathrm{pH}$ ). 


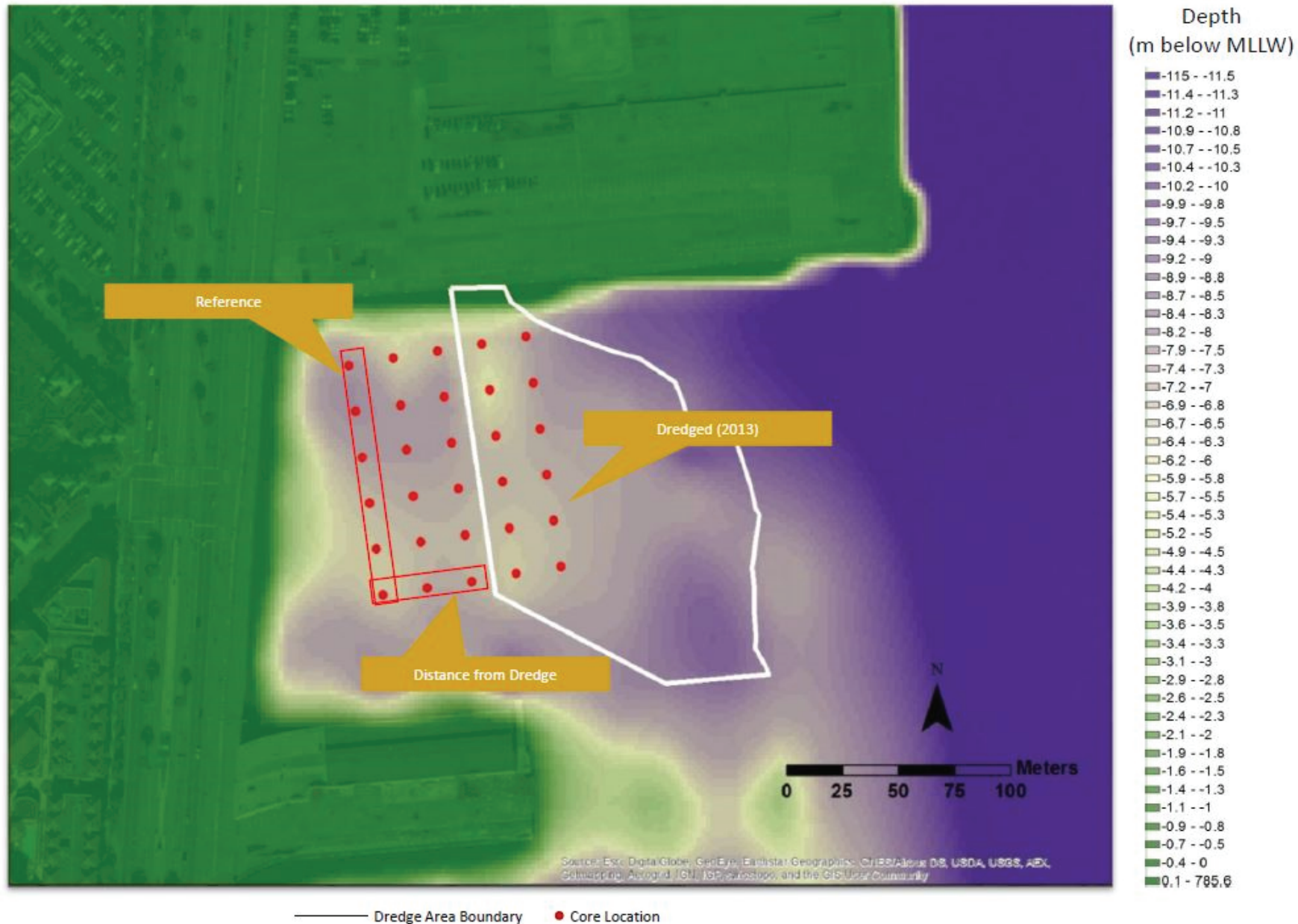

Figure 10. Port of San Francisco Pier 32 study site composed of an area between piers 32 and 36 in San Francisco. This site was only sampled as part of the pilot study. The white outlined area was dredged to 12 feet MLLW (mean lower low water) in 2013. The site contains 12 core locations in the dredged area and 18 undredged reference core locations collected along 2 transects of 6 core locations in the dredged marina/channel and 3 parallel transects of 6 core locations in the reference area between the dredged area and the shore.

Cores were immediately transported to the USGS Invertebrate Ecology Laboratory on ice and refrigerated until processed. Within 1-2 days, cores were rinsed through a 500-micrometer $(\mu \mathrm{m})$ mesh sieve, and fauna were retained by the sieve were preserved in a 70 percent ethanol with 1 percent rose bengal dye. All taxa within cores were sorted, identified, and enumerated. During all sampling periods except the pilot (November-December 2015), macroinvertebrates were sorted into four size-classes based on target fish foraging ecology: 0-4 mm, 4-12 mm, 12-24 mm, and 24-50 mm. Taxa from all samples were identified to a broad taxonomic level (class, order); however, macroinvertebrates in six cores that were randomly selected from each site (three from dredged locations and three from undredged locations) during each sampling period were identified to the lowest possible taxonomic level (family, genus, species). We determined the number of cores in which macroinvertebrates were identified to the lowest possible taxonomic level by processing multiple cores from each pilot sampling site until the number of new species found reached an asymptote.

Internal laboratory quality control measures included resorting and identifying a minimum of 10 percent of samples by a technician with equivalent or greater experience compared to the original sorter. This process was repeated until maximum error percentages were less than 10 percent for each sorter. We also sent sorted taxa from two randomly selected cores from each marina and time period to an external laboratory (EcoAnalysts, Inc., Moscow, Idaho) for identification to lowest taxonomic level. This was done both as a quality assurance measure to verify our in-house identification and to build a reference collection for more rapid and precise identification of future samples. 


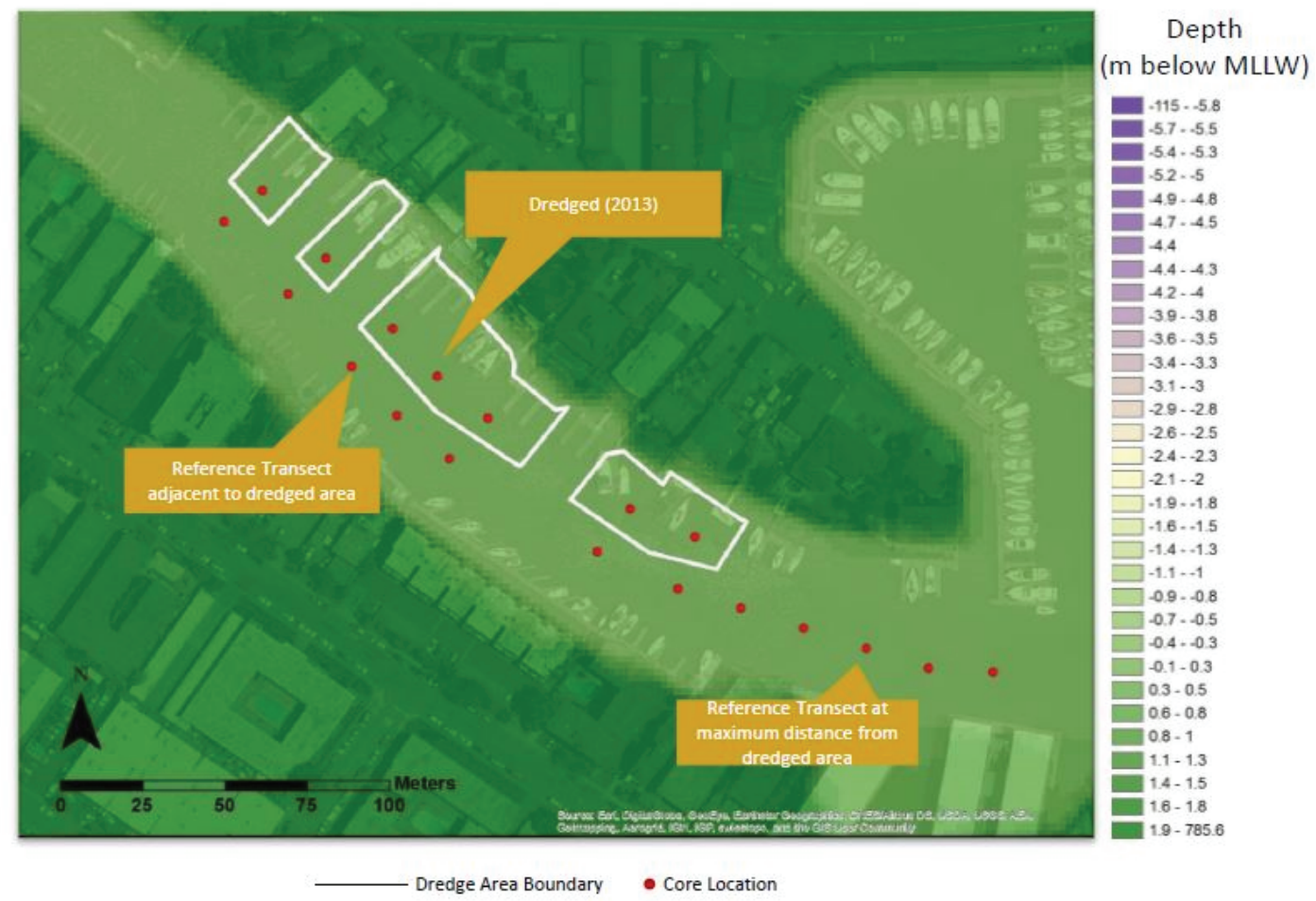

Figure 11. Mooring Road study site composed of dredged areas around residential docks in tidally influenced San Rafael Creek. Sampled as part of the pilot and full study. The white outlined area was dredged to 6 feet MLLW (mean lower low water) in 2013. The site contains 7 core locations in the dredged area and 12 undredged reference core locations collected along 1 transect of 7 core locations in dredged areas and 1 transect of 12 reference core locations that runs parallel to the dredged transect for 7 core locations and continues downstream from dredging for 5 core locations.

\section{Macroinvertebrate Density, Biomass, and Energy Estimations}

The density of macroinvertebrates at each core depth from each taxon and size class was calculated by averaging the densities from two replicate cores. Using the six cores from each site and season in which macroinvertebrates were identified to the lowest possible taxonomic level, we calculated the proportion of each lower taxonomic group within each broad taxonomic group for each size class, treatment (dredged or undredged), and site. We multiplied these proportions by the densities of each broad taxonomic group in each size class and treatment observed in the remaining cores at each site to obtain an estimated density for each lower-taxonomic group in each size class and treatment.

Next, we multiplied the observed (from the six cores identified to lowest taxonomic level) and estimated (from the remaining cores identified to broad taxonomic level) densities of macroinvertebrates in each taxonomic group and size class by the mean biomass per individual of that taxon and size class.

To determine mean biomass per individual for a given taxon and size class, macroinvertebrates were dried in a precision convection oven at 80 degrees Celsius $\left({ }^{\circ} \mathrm{C}\right)$ for 24 hours and weighed with an A and D Weighing HR-202i semi microbalance (0.1 mg; Abington, Oxfordshire, United Kingdom). Biomass was estimated for the most abundant taxa (Actiniaria, Amphipoda, Bivalvia, Copepoda, Corixidae, Cumacea, Decapoda, Errantia polychaeta, Gastropoda, Isopoda, Leptostraca, Nemertea, Oligochaeta, Ostracoda, Sedentaria Polychaeta, Tanaidacea, Sipuncula, Tunicata). Because of their limited densities, it was not possible to measure biomass for rare taxa, but the biomass of these taxa was considered negligible. When a broad taxonomic group was not present in any of the cores identified to the lowest possible taxonomic level, we used the average biomass of all possible lower taxonomic groups within that broad taxonomic group. We determined secondary production of each site by calculating the energy available to benthic foraging fishes. We calculated macroinvertebrate energy content (in kilojoules, $\mathrm{kJ}$ ) using published conversion factors (Cumminns and Wuycheck, 1971; Ricciardi and Bourget, 1998; Brey, 2001; Cauffope and Heymans, 2005) to convert dry biomass to ash-free dry biomass (AFDM) and AFDM to energy (kJ). Because biomass is size-dependent and macroinvertebrates were not separated into size classes during the pilot study, we did not calculate biomass or energy content for pilot study samples. 


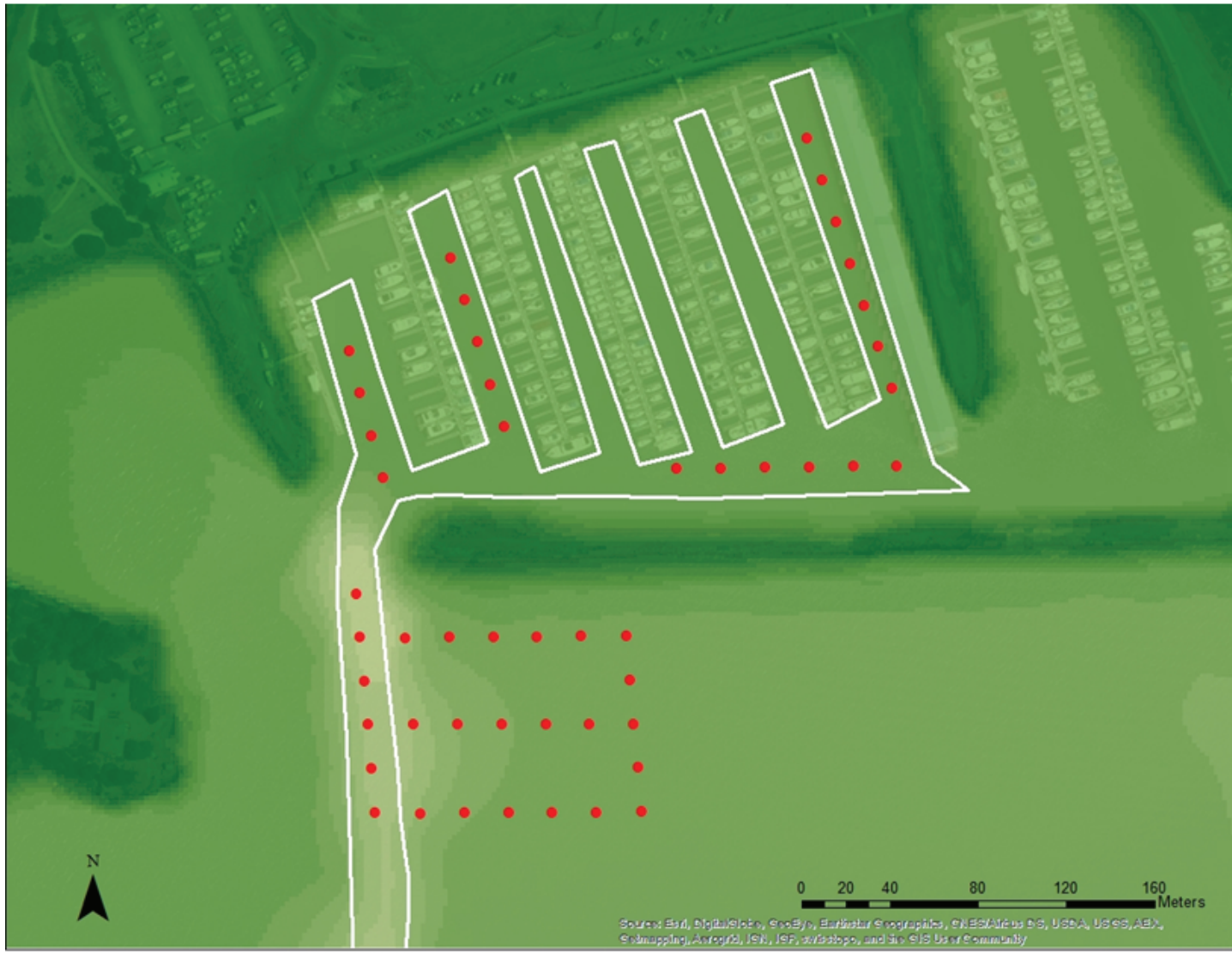

\section{Depth} ( $m$ below MLLW)

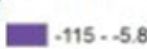

$.5 .7 \cdot-5.5$

$.5 .4 \cdot-5.3$

$-5.2 \cdot-5$

$-4.9 \cdot-4.8$

$-4.7 \cdot-4.5$

$-4.4$

$-4.4 \cdot-4.3$

$-4.2 \cdot-4$

$-3.9 \cdot-3.8$

$3.6 \cdot-3.5$

$-3.4 \cdot-3.3$

$-3.1 \cdot-3$

$-2.9 \cdot-2.8$

$-26-2.5$

$-2.4--2.3$

$-2.1--2$

$-1.9 \cdots 1.8$

$-1.6 \cdots 1.5$

$-1.4 \cdots 1.3$

$-1.1 \cdots 1$

$-0.9 \cdot-08$

$-0.7 \cdot-0.5$

$-0.4 \cdot-0.3$

$-0.1-0.3$

$0.3 \cdot 0.5$

06.0 .8

$0.8-1$

$1.1 \cdot 1.3$

W $1.4-1.5$

$1.6-1.8$

$1.9-785.6$

Figure 12. Loch Lomond Marina study site composed of a marina and entrance channel in San Rafael Bay sampled as part of the full study. The white outlined area was dredged to nine feet MLLW in 2015 . The site contains 28 core locations in the dredged area and 20 undredged reference core locations collected along 4 transects of 4 to 7 core locations in the dredged marina, 1 transect of 6 core locations in the dredged entrance channel, 1 reference transect of 5 core locations, and 3 transects of 5 core locations extending from the reference transect to the dredged entrance channel transect.

\section{Statistical Analyses}

We evaluated differences in salinity, bathymetry, and sediment characteristics that could influence macroinvertebrate density and biomass among sites using general linear models (GLMs) and linear discriminant function (LDF) analysis. We tested differences in the elevations of core locations among sites and differences in average demersal zone salinity among sites and sampling periods using GLMs. Differences in sediment characteristics including $\mathrm{pH}$, percent organic matter, percent sand, and percent silt were tested among sites and between dredged and undredged areas using LDF analysis with the package klaR (Weihs and others, 2005) in R v.3.4.1 (R Development Core Team, 2017). We included percent clay in figures, but not in statistical analyses because percent sand, percent silt, and percent clay for a single sample add up to 100 percent. Thus, they were perfectly correlated so only two of the three variables could be included in analyses. All variables were centered and scaled prior to LDF, and statistical significance of sediment characteristics was determined with forward, stepwise selection using the Wilks' Lambda ( $\lambda$ ) criterion. 


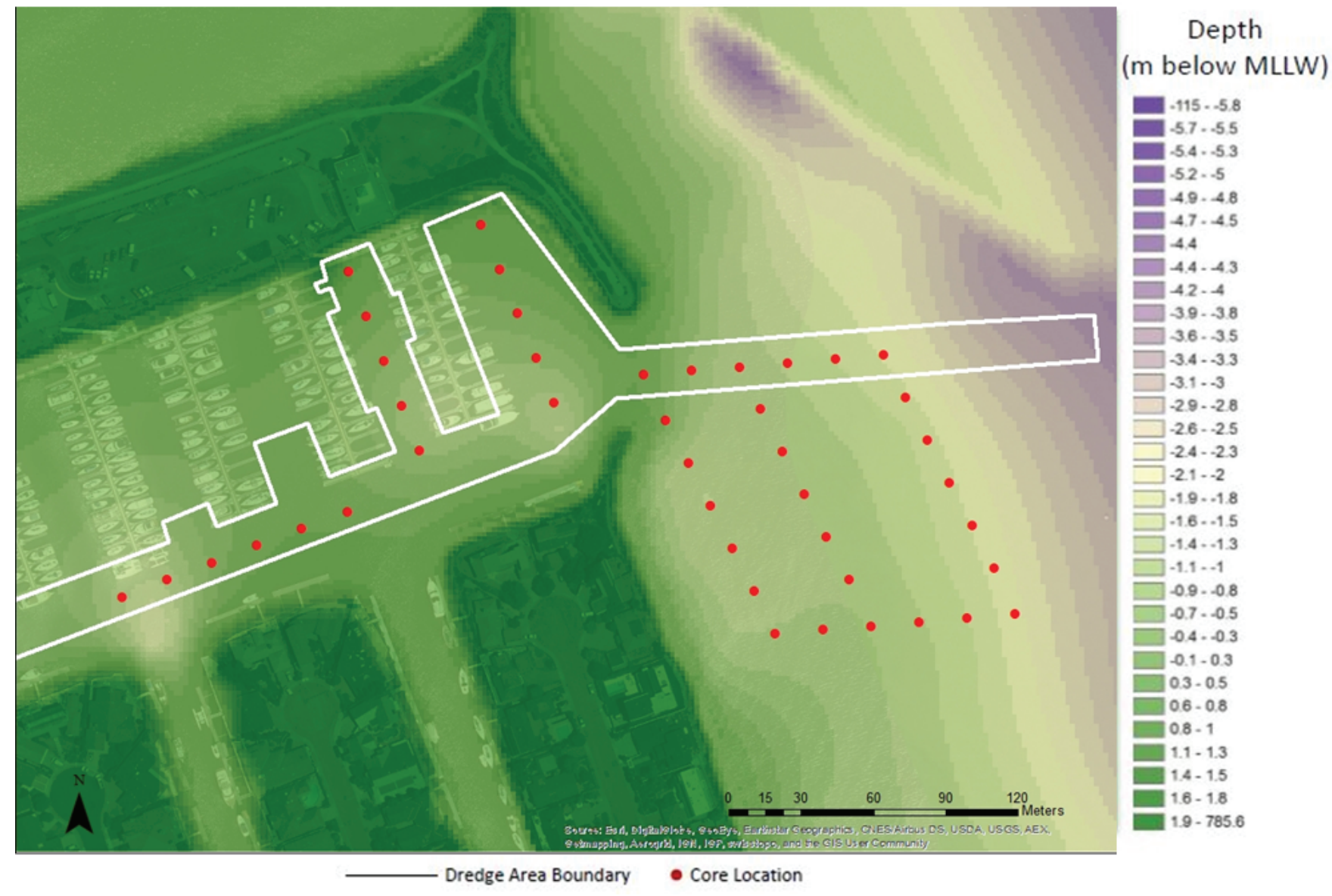

Figure 13. Paradise Cay Yacht Harbor study site composed of a marina and entrance channel in western San Francisco Bay. Sampled as part of the full study. The white outlined area was dredged to 10 feet MLLW (mean lower low water) in 2015. The site contains 22 core locations in the dredged area and 21 undredged reference core locations collected along 3 transects of 5 to 6 core locations in the dredged marina, 1 transect of 6 core locations in the dredged entrance channel, 1 reference transect of 6 core locations, and 3 transects of 5 core locations extending from the reference transect to the dredged entrance channel transect.

We assessed the effects of treatment (dredged versus undredged), time-since-dredging, and distance to the nearest dredged area separately on three response variables: (1) density (individuals per square meter $\left[\mathrm{m}^{2}\right]$ ), (2) dry biomass (grams per square meter $\left[\mathrm{g} / \mathrm{m}^{2}\right]$ ), and (3) energy content (kilojoules per square meter $\left[\mathrm{kJ} / \mathrm{m}^{2}\right]$ ) of macroinvertebrates using generalized linear mixed models (GLMMs) with the gamlss package (Stasinopoulos and Rigby, 2007) in R v.3.4.1 (R Development Core Team, 2017). For each response variable, we ran GLMMs for five different datasets that represented the spectrum of macroinvertebrate prey available to benthic foraging fishes: (1) $0-4 \mathrm{~mm}$ macroinvertebrates in surface cores ( $0-4 \mathrm{~cm}$ deep); (2) 4-12 $\mathrm{mm}$ macroinvertebrates in surface cores; (3) 12-24 mm macroinvertebrates in surface cores; (4) $24-50 \mathrm{~mm}$ macroinvertebrates in surface cores; and (5) 0-50 mm macroinvertebrates in whole cores ( $0-10 \mathrm{~cm}$ deep). For whole cores, macroinvertebrate size classes were combined because fish that could exploit this depth could also consume all prey sizes considered.
The GLMMs that tested the effects of treatment and distance to the nearest dredged area included macroinvertebrate data from cores collected in dredged and undredged areas, but GLMMs that tested the effect of time-since-dredging included data from cores collected in dredged areas only. The effect of distance to the nearest dredged area was tested to evaluate both the effect size of a dredged area, as well as to provide insight on species-specific recolonization of dredged sites from adjacent undredged areas. All GLMMs were run using a zero-adjusted gamma distribution because our macroinvertebrate datasets were zero-inflated. We included season, salinity, and elevation of the core location in all models as fixed effects. We determined the best random effects structure for GLMMs by comparing AIC scores among models with and without each of the random effects. Site and transect were included as random effects in GLMMs that tested the effects of treatment and distance to the nearest dredged area, and site was included as a random effect in GLMMs that tested the effect of time-since-dredging. 
Table 4. Sampling scenarios used in simulation power analyses to determine project sample size. Scenarios had a variable number of sites (marinas), and each marina had one dredged and one undredged area.

[Scenarios had a variable number of sites (marinas), and each marina had one dredged and one undredged area. Within each of these areas we varied the number of transects, cores, and core replicates.]

\begin{tabular}{cccccc}
\hline $\begin{array}{c}\text { Site } \\
\text { (marina) }\end{array}$ & $\begin{array}{c}\text { Areas } \\
\text { (dredged and } \\
\text { undredged) }\end{array}$ & $\begin{array}{c}\text { Transects } \\
\text { (per area) }\end{array}$ & $\begin{array}{c}\text { Cores } \\
\text { (per transect) }\end{array}$ & $\begin{array}{c}\text { Replicates } \\
\text { (per core) }\end{array}$ & $\begin{array}{c}\text { Total number } \\
\text { of core } \\
\text { samples }\end{array}$ \\
\hline 2 & 2 & 2 & 2 & 2 & 32 \\
3 & 2 & 1 & 5 & 3 & 90 \\
5 & 2 & 2 & 5 & 1 & 100 \\
5 & 2 & 1 & 5 & 3 & 150 \\
5 & 2 & 2 & 5 & 2 & 200 \\
5 & 2 & 1 & 8 & 3 & 240 \\
5 & 2 & 2 & 5 & 3 & 300 \\
5 & 2 & 2 & 8 & 2 & 320 \\
10 & 2 & 2 & 5 & 2 & 400 \\
5 & 2 & 2 & 10 & 2 & 400 \\
\hline
\end{tabular}




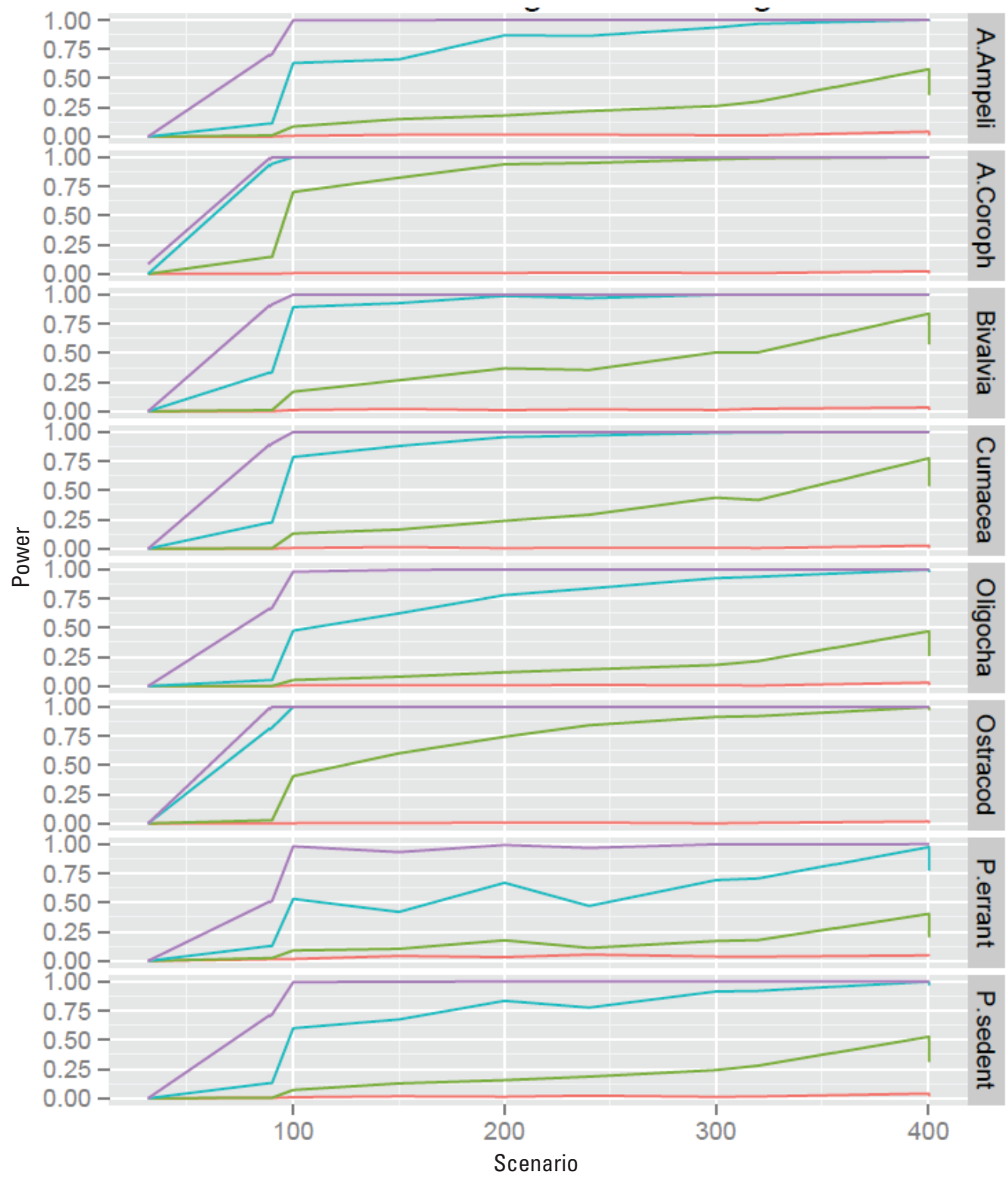

Figure 14. Power analysis curves for individual taxa groups based on the comprehensive U.S. Geological Survey Dumbarton macroinvertebrate dataset. Scenarios depicted on the $\mathrm{x}$-axis are for 10 simulated datasets (listed in table 1) representing different combinations of sites, transects, and replicate cores. The $y$-axis indicates the percent power to determine the difference between dredged and undredged areas. Colored lines represent macroinvertebrate reductions of 0 percent (red), 25 percent (green), 50 percent (blue), and 75 percent (purple) owing to dredging. 


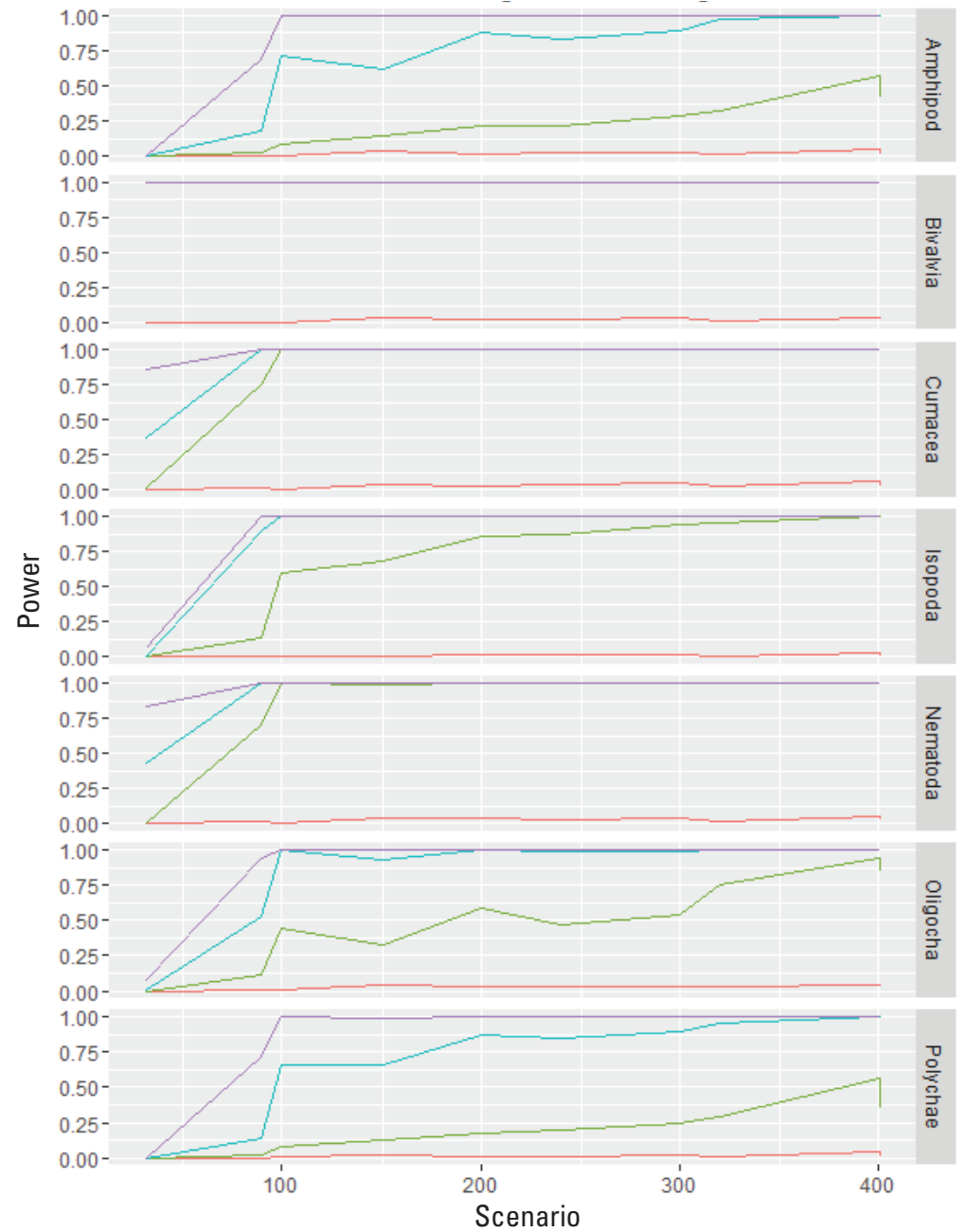

Figure 15. Power analysis curves for individual taxa groups based on the 2015 pilot study macroinvertebrate dataset. Scenarios depicted on the $\mathrm{x}$-axis are for 10 simulated datasets (listed in table 4) representing different combinations of sites, transects, and replicate cores. The $y$-axis indicates the percent power to determine the difference between dredged and undredged areas. Colored lines represent macroinvertebrate reductions of 0 percent (red), 25 percent (green), 50 percent (blue), and 75 percent (purple) owing to dredging. 


\section{Results}

\section{Salinity, Elevation, and Sediment Characteristics Among Sites}

Overall, demersal zone salinities measured during the winter sampling period of January 2017 were significantly lower at all sites than salinities measured during the other sampling periods (table 5), reflecting the unusually heavy rainfall from a series of atmospheric rivers during this season. Despite some significant differences in demersal zone salinity among sites (fig. 16; table 5), we observed the same general pattern at each site; salinities were lowest during the unusually wet January 2017 sampling period and were similar among the pilot sampling period (November-December 2015) and the two summer sampling periods (August 2016 and August 2017; fig. 16). Practical Salinity Unit (psu) measurements ranged from 2.37 at Mooring Road in January 2017 to 32.66 psu at Strawberry Channel in August 2016 (fig. 16). Demersal zone salinities at Richardson Bay and Strawberry Channel had the least seasonal variability (fig. 16). In contrast, large differences between summer and winter demersal salinities were observed at Mooring Road and Yacht Harbor (fig. 16).

Among sites, elevation of core locations ranged from $-2.2 \mathrm{~m}$ to $0.3 \mathrm{~m}$, with both the highest and lowest points at Yacht Harbor. We observed notable differences in core elevations among sites (table 6), but generally, elevations at all

Table 5. General Linear Model (GLM) results for demersal salinity as a function of site (Loch Lomond, Mooring Road, Paradise Cay, Richardson Bay, Strawberry Channel, and Yacht Harbor) and sampling period (November 2015, August 2016, January 2017, and August 2017).

[Loch Lomond is the reference site, and November 2015 is the reference sampling period for the analysis. Abbreviation: $<$, less than]

\begin{tabular}{lrrrr}
\hline \multicolumn{1}{c}{ Fixed effect } & Estimate & $\begin{array}{c}\text { Standard } \\
\text { error }\end{array}$ & Z-value & \multicolumn{1}{c}{$\boldsymbol{p}$} \\
\hline Intercept & 28.731 & 1.850 & 15.534 & $<0.001$ \\
Site: Mooring Road & -4.205 & 1.632 & -2.577 & 0.013 \\
Site: Paradise Cay & -0.177 & 1.600 & -0.111 & 0.912 \\
Site: Richardson Bay & 4.669 & 1.620 & 2.882 & 0.006 \\
Site: Strawberry Channel & 5.179 & 1.653 & 3.132 & 0.003 \\
Site: Yacht Harbor & -1.408 & 1.690 & -0.833 & 0.409 \\
Sampling 2016-8 & 0.919 & 1.574 & 0.584 & 0.562 \\
Sampling 2017-1 & -14.736 & 1.559 & -9.454 & $<0.001$ \\
Sampling 2017-8 & -0.513 & 1.574 & -0.326 & 0.746 \\
\hline
\end{tabular}

sites fell within a relatively narrow range (fig. 17). In addition, core elevations at dredged and undredged areas were similar within sites (fig. 17).

Sediment characteristics including percent organic matter, $\mathrm{pH}$, percent sand, percent silt, and percent clay were not different between shallow $(0-4 \mathrm{~cm})$ and deep $(4-10 \mathrm{~cm})$ core segments within each site (figs. 18-23). Three sediment characteristics, percent silt $(\lambda=0.77, p<0.001)$, percent sand $(\lambda=0.59, p<0.001)$, and $\mathrm{pH}(\lambda=0.49, p<0.001)$, contributed significantly to an LDF that explained differences in sediments among sites (figs. 18-23). Percent silt ranged from $36.82 \pm 1.00$ (mean \pm standard error) at Mooring Road to $48.16 \pm 1.16$ at Yacht Harbor. Percent sand ranged from $14.41 \pm 0.92$ at Loch Lomond to $24.80 \pm 1.28$ at Richardson Bay, and mean $\mathrm{pH}$ ranged from $6.92 \pm 0.07$ at Strawberry Channel to $7.27 \pm 0.03$ at Loch Lomond. In addition, percent organic matter $(\lambda=0.84, p<0.001)$, percent silt $(\lambda=0.81$, $p=0.01)$, and percent sand $(\lambda=0.79, p=0.02)$, contributed significantly to an LDF that explained differences in sediment between dredged and undredged areas. Percent organic matter and percent sand $(2.97 \pm 0.57$ and $18.63 \pm 0.88$, respectively) were greater in dredged areas than in undredged areas $(2.48 \pm 0.05$ and $17.51 \pm 0.80)$, whereas percent silt was greater in undredged areas $(47.69 \pm 0.75)$ compared to dredged areas $(42.58 \pm 0.56$; figs. $18-20)$. Despite these significant differences, sediment texture based on percent sand, silt, and clay was similar among sites and between dredged and undredged areas, with most sediments classified as loams with high percentages of silt or clay (fig. 23).

Table 6. General Linear Model (GLM) results for core elevation as a function of site (Loch Lomond, Mooring Road, Paradise Cay, Richardson Bay, Strawberry Channel, and Yacht Harbor).

[Loch Lomond is the reference site for the analysis. Abbreviation: $<$, less than]

\begin{tabular}{lrrrr}
\hline \multicolumn{1}{c}{ Fixed effect } & Estimate & $\begin{array}{c}\text { Standard } \\
\text { error }\end{array}$ & Z-value & $\boldsymbol{p}$ \\
\hline Intercept & -0.412 & 0.065 & -6.368 & $<0.001$ \\
Site: Mooring Road & 0.278 & 0.121 & 2.290 & 0.023 \\
Site: Paradise Cay & -0.537 & 0.093 & -5.778 & $<0.001$ \\
Site: Richardson Bay & -0.506 & 0.102 & -4.951 & $<0.001$ \\
Site: Strawberry Channel & 0.111 & 0.097 & 1.148 & 0.252 \\
Site: Yacht Harbor & -0.759 & 0.094 & -8.073 & $<0.001$ \\
\hline
\end{tabular}




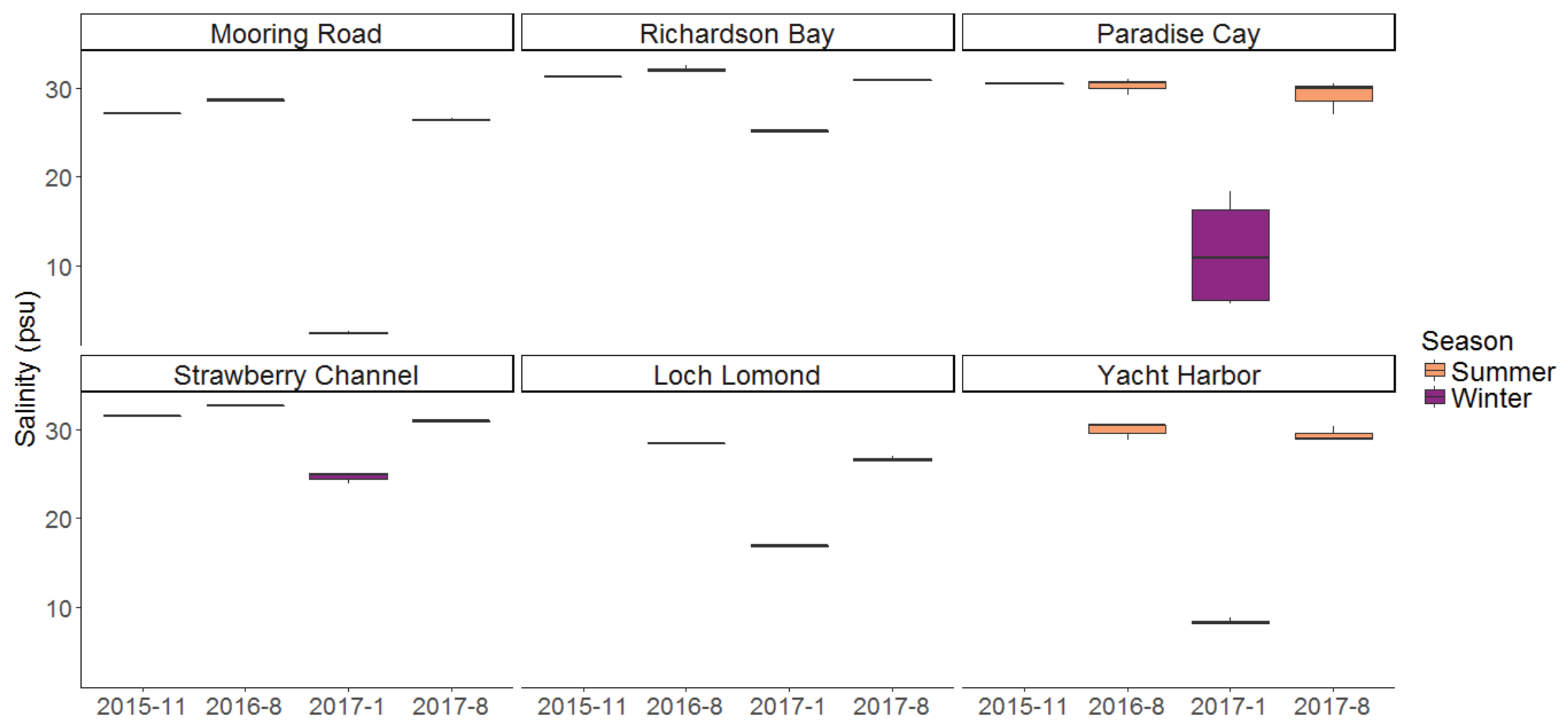

Figure 16. Summer and winter demersal salinity (psu) at six coring sites (Mooring Road, Richardson Bay, Paradise Cay, Strawberry Channel, Loch Lomond, and Yacht Harbor) during four sampling periods (November 2015, August 2016, January 2017, and August 2017). Boxes show values of the first and third quartiles around the median. Whiskers extend to 1.5 -times the interquartile range. 


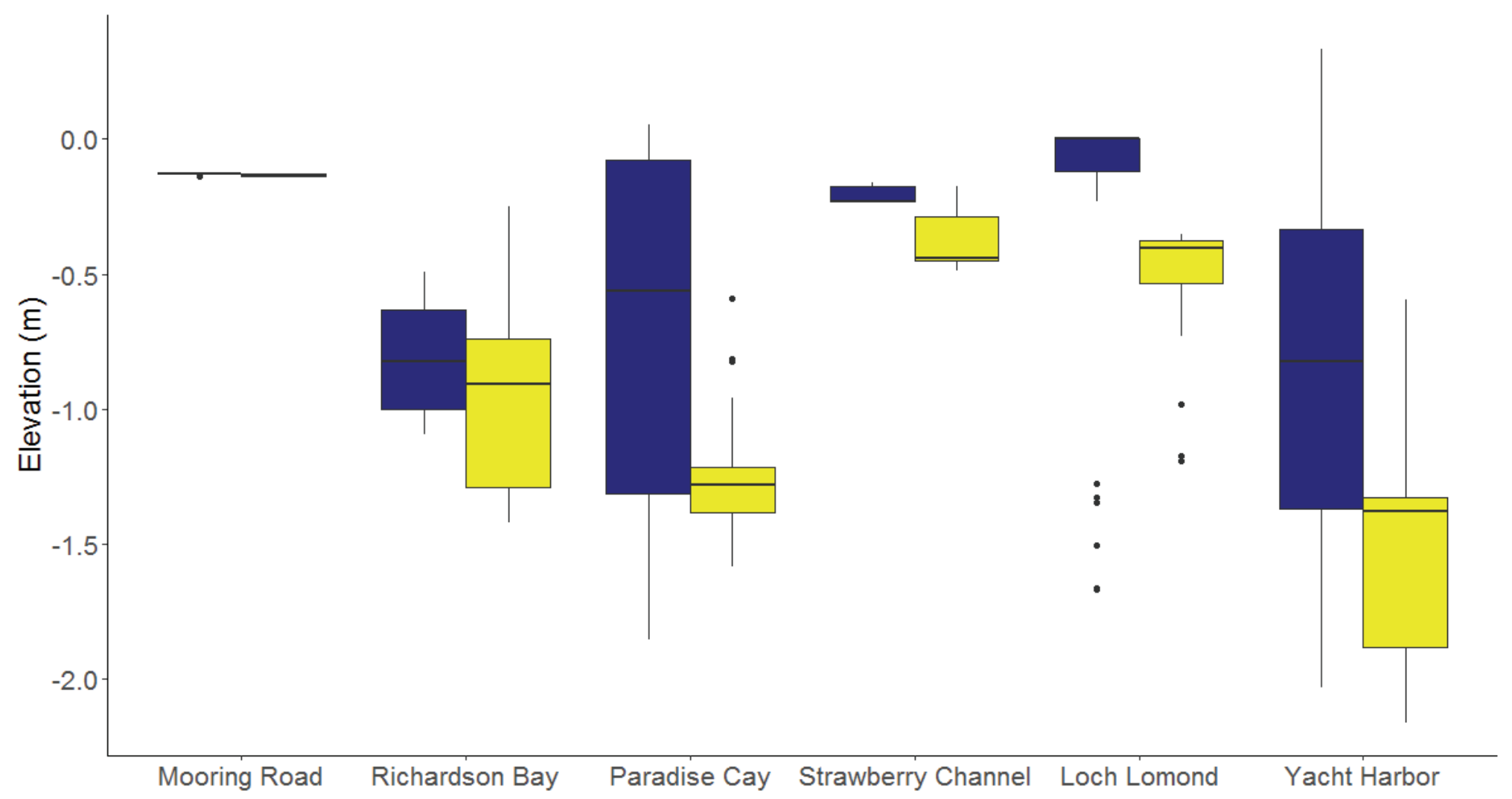

Figure 17. Elevation (meters) in dredged (blue) and undredged (yellow) areas at six study sites (Mooring Road, Richardson Bay, Paradise Cay, Strawberry Channel, Loch Lomond, and Yacht Harbor). Boxes show values of the first and third quartiles around the median. Whiskers extend to 1.5 -times the interquartile range. 


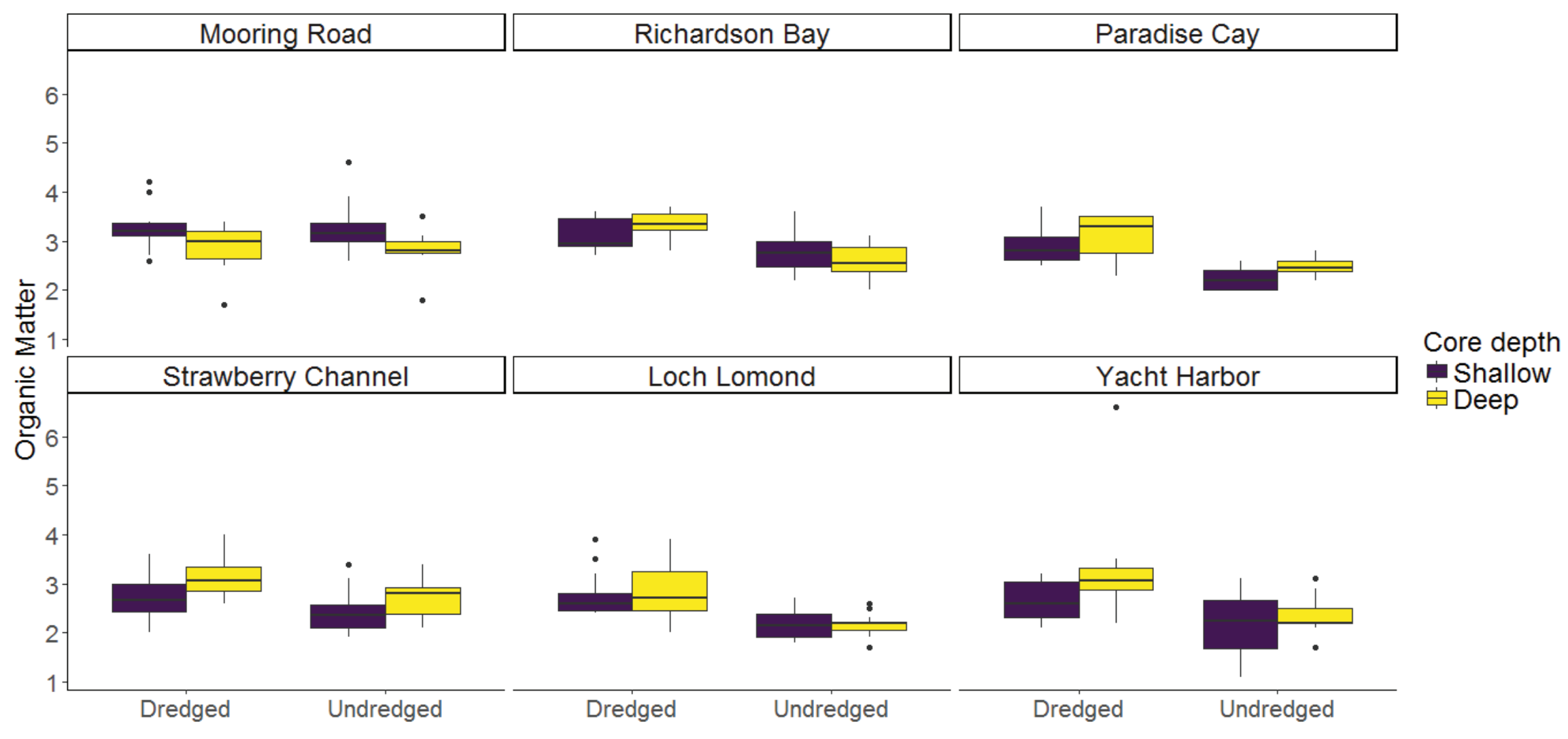

Figure 18. Sediment organic matter content measured as percent loss on ignition in shallow (0-4 centimeters [cm]; purple) and deep (4-10 cm; yellow) cores of dredged and undredged areas at six study sites (Mooring Road, Richardson Bay, Paradise Cay, Strawberry Channel, Loch Lomond, and Yacht Harbor) in San Francisco Bay. 


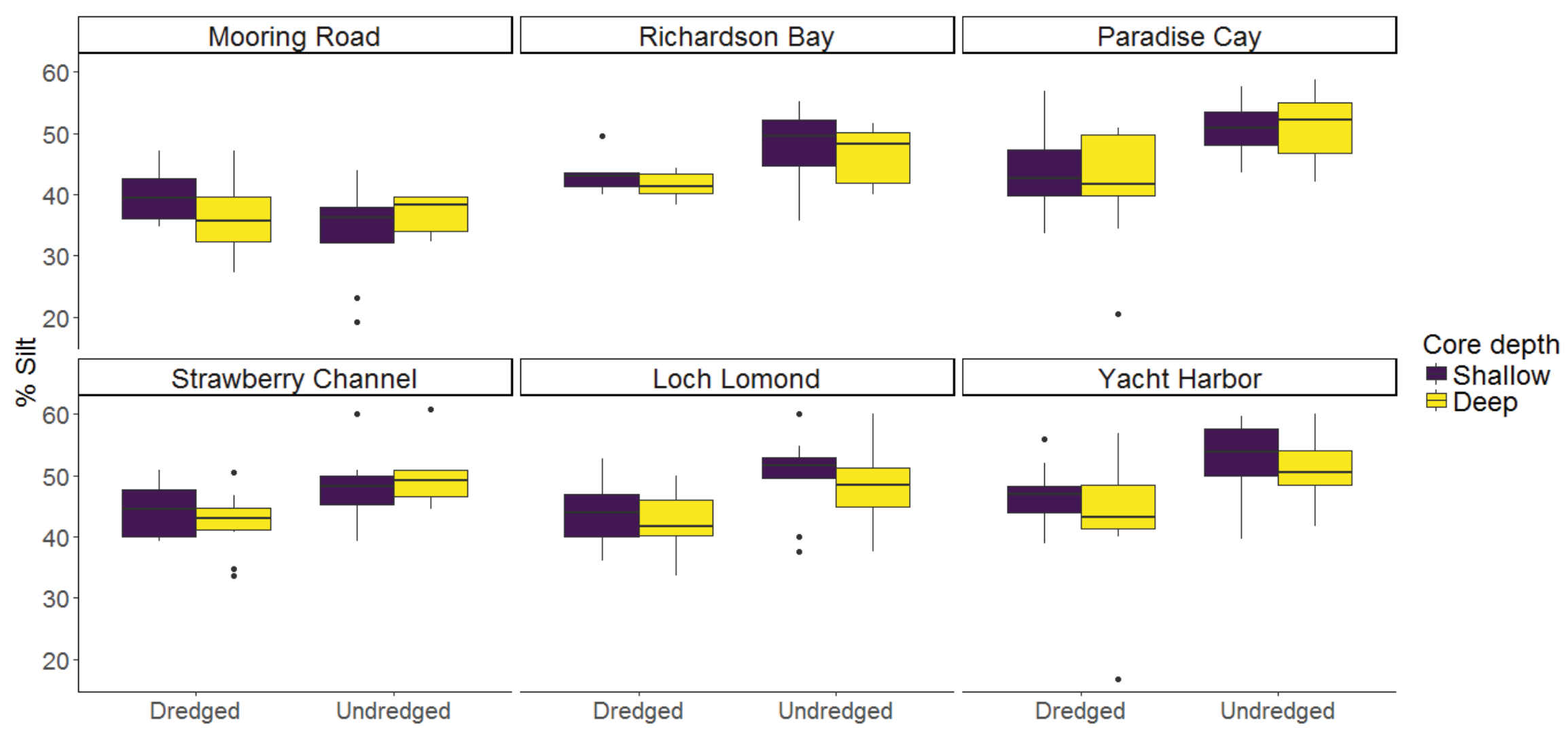

Figure 19. Percent silt in sediments from shallow (0-4 centimeters [cm]; purple) and deep (4-10 $\mathrm{cm}$; yellow) cores of dredged and undredged areas at six study sites (Mooring Road, Richardson Bay, Paradise Cay, Strawberry Channel, Loch Lomond, and Yacht Harbor) in San Francisco Bay. 


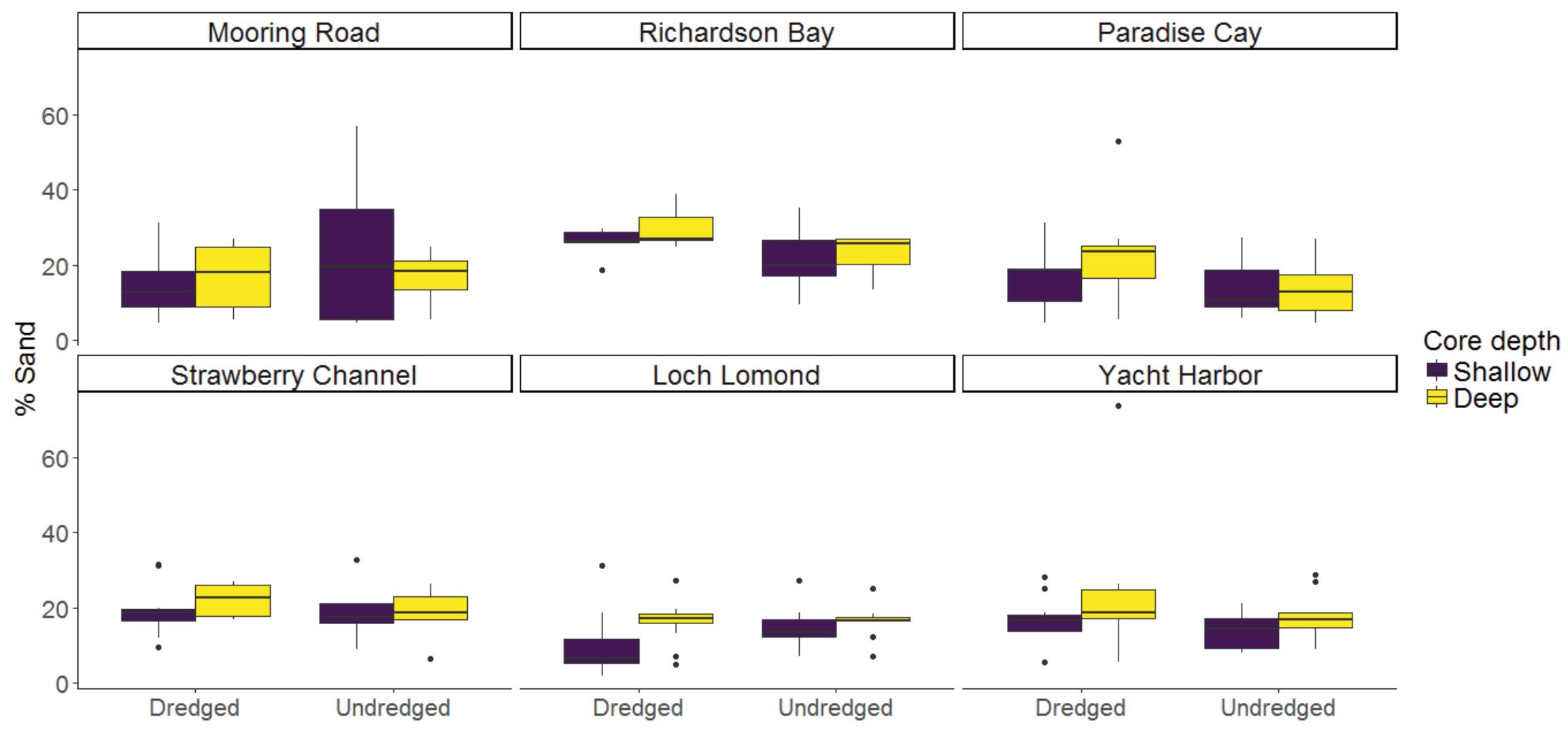

Figure 20. Percent sand in sediments from shallow (0-4 centimeters [cm]; purple) and deep (4-10 cm; yellow) cores of dredged and undredged areas at six study sites (Mooring Road, Richardson Bay, Paradise Cay, Strawberry Channel, Loch Lomond, and Yacht Harbor) in San Francisco Bay. 


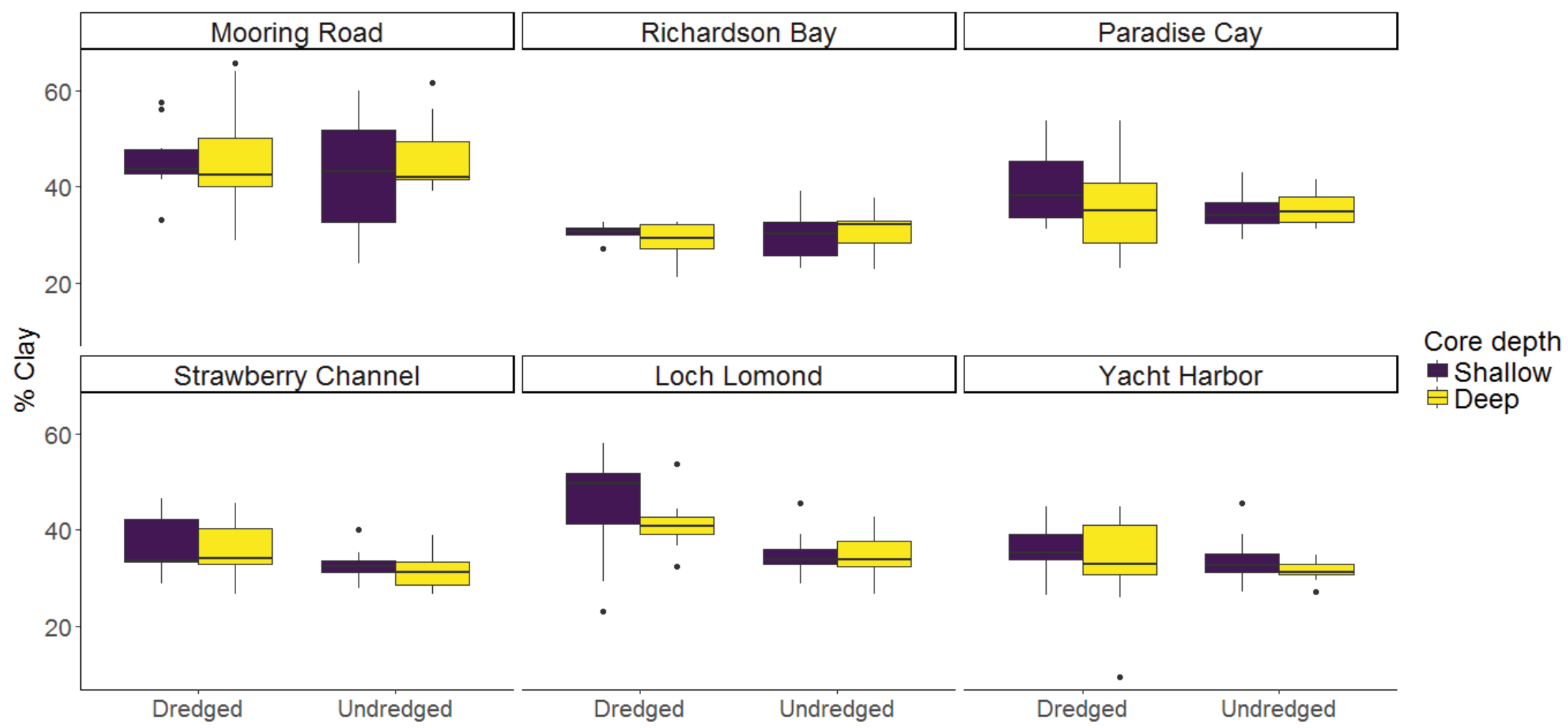

Figure 21. Percent clay in sediments from shallow (0-4 centimeters [cm]; purple) and deep (4-10 cm; yellow) cores of dredged and undredged areas at six study sites (Mooring Road, Richardson Bay, Paradise Cay, Strawberry Channel, Loch Lomond, and Yacht Harbor) in San Francisco Bay. 


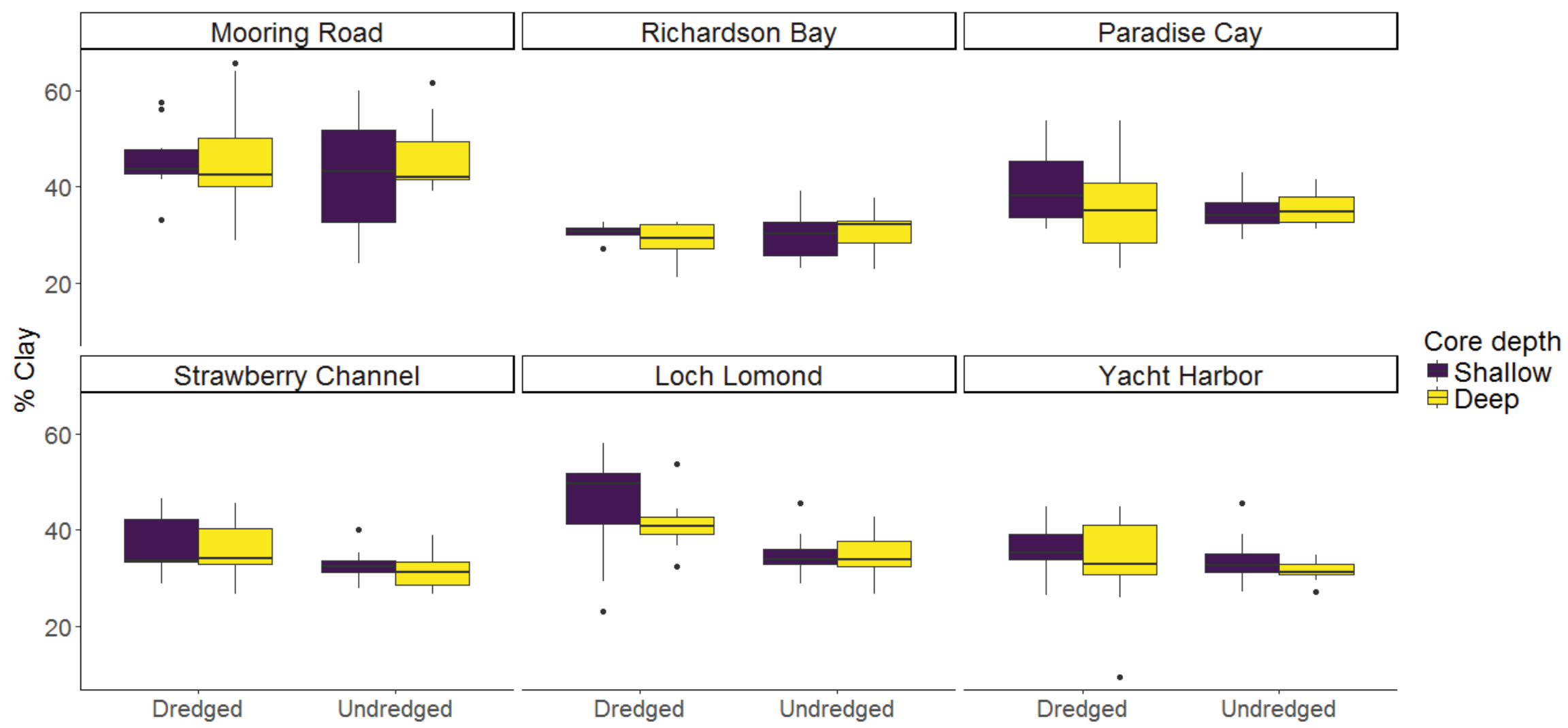

Figure 22. Sediment pH measured in shallow (0-4 centimeters [cm]; purple) and deep (4-10 cm; yellow) cores of dredged and undredged areas at six study sites (Mooring Road, Richardson Bay, Paradise Cay, Strawberry Channel, Loch Lomond, and Yacht Harbor) in San Francisco Bay. 


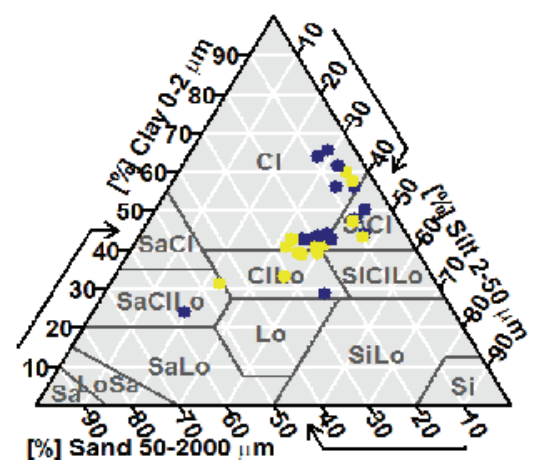

Strawberry Channe

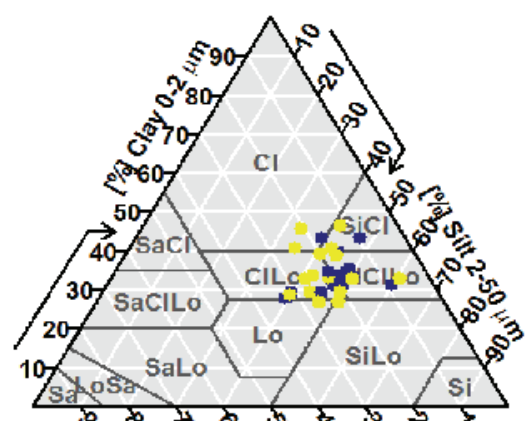

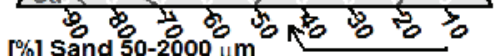

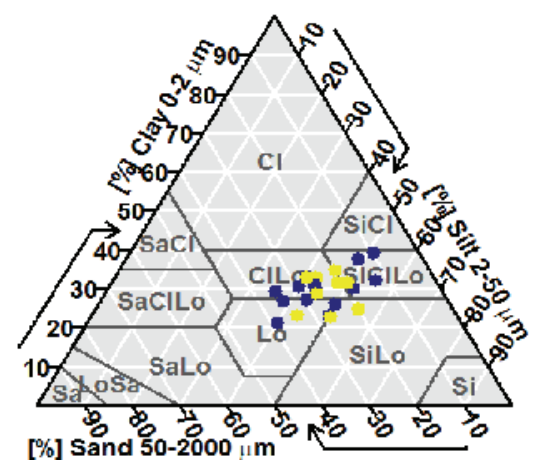

Loch Lomond

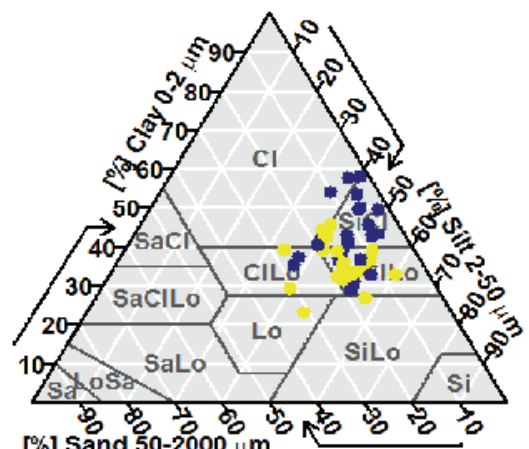

Treatment

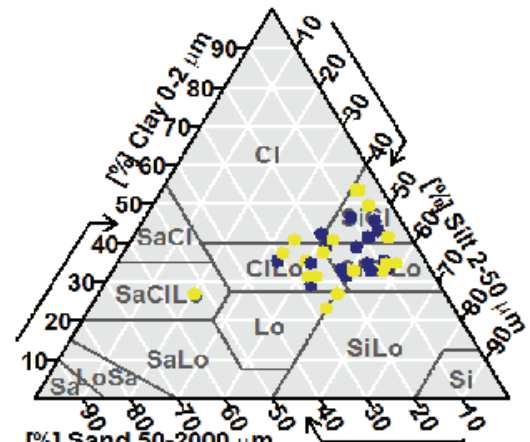

[\%] sand $50-2000$ \%

Yacht Harbor

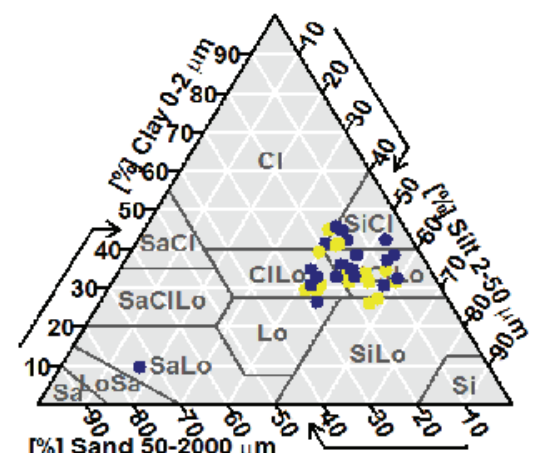

Figure 23. Sediment triangles used to classify sediment texture with percent sand, percent silt, and percent clay from sediments collected in dredged (blue) and undredged (yellow) areas at six study sites (Mooring Road, Richardson Bay, Paradise Cay, Strawberry Channel, Loch Lomond, and Yacht Harbor) in San Francisco Bay. Textures abbreviations: Sand (Sa), Silt (Si), Clay (CI), Loam (Lo). 


\section{Within-Site Macroinvertebrate Community Composition, Density, Biomass, and Energy Content}

We collected a total of 1,644 whole benthic cores: 288 during the pilot sampling effort and 1,356 during the full study. We identified 33 broad taxonomic groups of macroinvertebrates among the 6 sampling sites and 4 sampling dates. Although the focus of our study was on the foraging value of broad taxonomic macroinvertebrate groups, we identified organisms from a random subsample of cores from each site to lowest taxa as a measure of structural recovery. We detected 104 distinct taxa in the shallow $(0-4 \mathrm{~cm})$ depth (table 7) compared to 43 taxa in the deep $(4-10 \mathrm{~cm})$ depth range (table 8). Within the surface sediments $(0-4 \mathrm{~cm})$, we generally found a greater taxonomic richness in undredged areas compared to dredged areas (undredged:dredge taxonomic richness ratio; 1.3 Loch Lomond, 1.4 Mooring Road, 1.2 Paradise Cay, 0.9 Richardson Bay, 1.5 Strawberry Channel, and 1.9 Yacht Harbor). In the shallow sediments of Richardson Bay, we detected greater taxonomic richness within dredged areas compared to undredged (dredge area 59 taxa, undredged area 52 taxa). A similar pattern was also observed within deeper sections $(4-10 \mathrm{~cm})$ of the sediment profile where most sites had greater taxa richness in undredged areas (undredged:dredge taxonomic richness ratio; 0.9 Loch Lomond, 1.3 Mooring Road, 1.5 Paradise Cay, 1.0 Richardson Bay, 1.3 Strawberry Channel, and 1.7 Yacht Harbor). In the deep cores, we detected greater taxonomic richness within dredged areas compared to undredged at Loch Lomond (dredged area 12 taxa, undredged area 11 taxa).

During our study, we identified 13 adult specimens of the horseshoe shrimp (Lightiella serendipita), nearly doubling the number of known samples for this rare endemic Cephalocarid species. Thought to be extinct, this species has not been observed in SFB since 1988 (Jones, 1961; Schemel and others, 1988, 1990), despite previous attempts to locate it during 1997-99 (C. Rogers, University of Kansas, written commun., 2017, 2018) and in 2000 (R. Mooi, California Academy of Sciences, written commun., 2017, 2018. Based on the number of samples we collected, L. serendipita had a detection rate of 0.5 percent, making this finding a truly serendipitous rediscovery of the species.

To facilitate statistical analyses and interpretation of functional foraging habitat characteristics for fish, we consolidated macroinvertebrates into broad taxonomic groups (Amphipoda, Bivalvia, Cumacea, Nematoda, Oligochaeta, Polychaeta, and other taxa). Macroinvertebrate cumulative community composition, density, biomass, and energy content varied somewhat among study locations (figs. 24-26; table 9). Macroinvertebrate densities were generally dominated by Polychaeta and Amphipoda and to a lesser extent Oligochaeta, Bivalvia, and Nematoda across all sites (fig. 24). On the other hand, macroinvertebrate biomass was clearly dominated by Bivalvia (especially at Mooring Road) and Polychaeta, with negligible contributions from other taxonomic groups (fig. 25), while Polychaeta contributed more substantially to energy content at each site (fig. 26). Below we summarize cumulative (calculated across all available sampling periods) site-specific trends in macroinvertebrate density, biomass, and energy content between dredged areas and their paired undredged reference areas.

\section{Dredged in 2013}

Overall, at Mooring Road macroinvertebrate density was 39 percent greater in undredged areas than dredged areas. Dominant taxa in dredged areas included bivalves (34 percent of the total density), polychaetes ( 24 percent), and oligochaetes (11 percent). In undredged areas, the community was predominated by polychaetes ( 30 percent) and bivalves (23 percent) and contained more oligochaetes (16 percent) relative to dredged areas. Biomass and energy content at both dredged and undredged areas in Mooring Road were driven primarily by bivalves and were 6 and nearly 2.5 times greater, respectively than the site with the next greatest biomass, Loch Lomond undredged (table 9; figs. 24-26).

Dredged and reference areas at the Pier 32 site sampled only during the pilot study were numerically dominated by polychaetes and contained more polychaetes than most other sites, except for the Paradise Cay dredged area. Polychaetes comprised 94 percent of the community in dredged areas and 78 percent in undredged areas, which also contained 16 percent bivalves (fig. 27). Biomass and energy content of macroinvertebrates were not measured during the pilot study.

At Richardson Bay, overall density was 29 percent greater in undredged areas than in dredged areas (table 9). Dredged areas were dominated by polychaetes ( 56 percent) followed by nematodes ( 20 percent) and oligochaetes (10 percent). Macroinvertebrate communities in undredged areas were dominated by nematodes (37 percent) and polychaetes ( 27 percent), but amphipods (16 percent) were more abundant than oligochaetes (11 percent). Biomass at Richardson Bay was 124 percent greater in the undredged area than the dredged area but biomass was dominated by bivalves and polychaetes in both areas. In the dredged area, bivalves accounted for 62 percent of the biomass, while polychaetes accounted for 36 percent; in the undredged area, bivalves and polychaetes accounted for almost equal percentages of the biomass (49 percent and 47 percent, respectively; table 9; fig. 25). Overall, the undredged area provided 166 percent more energy for demersal fish than the dredged area (table 9; fig. 26). In both dredged and undredged areas, polychaetes provided the greatest proportion of the energy content (75 percent and 83 percent respectively; fig. 26). 
Table 7. Macroinvertebrate taxa identified in shallow (0-4 centimeters [cm];) cores from dredged (D) and undredged (U) locations at six sites-Mooring Road (MR), Richardson Bay (RB), Paradise Cay (PC), Strawberry Channel (SC), Loch Lomond (LL), and Yacht Harbor (YH)—in San Francisco Bay, California.

[In some cases, we identified to broader taxa (such as family) when pieces of organisms were encountered or when organisms were too small for distinguishing identifying features. Broader taxonomic categories are not included in total taxa count if they were represented by lower taxonomic identification (ID)]

\begin{tabular}{|c|c|c|c|c|c|c|c|c|c|c|c|c|c|c|}
\hline \multirow{2}{*}{ Broad taxonomic group } & \multirow{2}{*}{ Lowest taxonomic ID } & \multirow{2}{*}{$\begin{array}{l}\text { Taxonomic } \\
\text { rank }\end{array}$} & \multicolumn{2}{|c|}{ MR } & \multicolumn{2}{|c|}{ RB } & \multicolumn{2}{|c|}{ PC } & \multicolumn{2}{|c|}{ SC } & \multicolumn{2}{|c|}{ LL } & \multicolumn{2}{|c|}{ YH } \\
\hline & & & D & $\mathbf{U}$ & D & $\mathbf{U}$ & D & $\mathbf{U}$ & D & $\mathbf{U}$ & D & $\mathbf{U}$ & D & $\mathbf{U}$ \\
\hline Actiniaria & Actiniaria & Order & & & $\mathrm{X}$ & $\mathrm{X}$ & $\mathrm{X}$ & & $\mathrm{X}$ & $\mathrm{X}$ & $\mathrm{X}$ & $\mathrm{X}$ & $\mathrm{X}$ & $\mathrm{X}$ \\
\hline \multirow{5}{*}{ Amphipoda } & Ampithoe & Genus & & & & & & & $\mathrm{X}$ & $X$ & & & & \\
\hline & Caprella & Genus & & & & $\mathrm{X}$ & $\mathrm{X}$ & $\mathrm{X}$ & & $\mathrm{X}$ & & $X$ & & \\
\hline & Monocorophium & Genus & $\mathrm{X}$ & $\mathrm{X}$ & $\mathrm{X}$ & $\mathrm{X}$ & $\mathrm{X}$ & $\mathrm{X}$ & $\mathrm{X}$ & $\mathrm{X}$ & $\mathrm{X}$ & $\mathrm{X}$ & $\mathrm{X}$ & $\mathrm{X}$ \\
\hline & Paradexamine & Genus & & & & $\mathrm{X}$ & & $\mathrm{X}$ & & $\mathrm{X}$ & & & & \\
\hline & Sinocorophium & Genus & & $X$ & & $X$ & $\mathrm{X}$ & & & & & & & $X$ \\
\hline Annelida & Annelida & Phylum & & & & & & & & & & & $\mathrm{X}$ & \\
\hline \multirow{4}{*}{ Bivalvia } & Kurtiella tumida & Species & & & & & & & & & & & & $X$ \\
\hline & Macoma petalum & Species & $\mathrm{X}$ & $\mathrm{X}$ & $\mathrm{X}$ & & & & $\mathrm{X}$ & $\mathrm{X}$ & $\mathrm{X}$ & $\mathrm{X}$ & & \\
\hline & Mya arenaria & Species & & & $\mathrm{X}$ & & & $\mathrm{X}$ & & & & & & \\
\hline & Potamocorbula amurensis & Species & & $\mathrm{X}$ & $\mathrm{X}$ & $\mathrm{X}$ & & $\mathrm{X}$ & $\mathrm{X}$ & $\mathrm{X}$ & $\mathrm{X}$ & $\mathrm{X}$ & $\mathrm{X}$ & $\mathrm{X}$ \\
\hline \multirow[t]{3}{*}{ Bivalvia } & Ruditapes philippinarum & Species & & & & & & & & & & $\mathrm{X}$ & & $\mathrm{X}$ \\
\hline & Theora lubrica & Species & & & $\mathrm{X}$ & & $\mathrm{X}$ & $\mathrm{X}$ & & & $\mathrm{X}$ & $X$ & $\mathrm{X}$ & $\mathrm{X}$ \\
\hline & Other Bivalvia & Class & $X$ & $X$ & $\mathrm{X}$ & $X$ & $\mathrm{X}$ & $X$ & $\mathrm{X}$ & $\mathrm{X}$ & $X$ & $X$ & $\mathrm{X}$ & $X$ \\
\hline Bryozoa & Bryozoa & Phylum & $X$ & $\mathrm{X}$ & $\mathrm{X}$ & $X$ & $\mathrm{X}$ & & $\mathrm{X}$ & $X$ & & $X$ & $\mathrm{X}$ & $\mathrm{X}$ \\
\hline Cirripidea & Cirripidea & Subphylum & & & & & & & & & & $\mathrm{X}$ & & \\
\hline \multirow[t]{2}{*}{ Decapoda } & Cancridae & Family & & & & & & $\mathrm{X}$ & & & & & & \\
\hline & Carcinus maenas & Species & & & & & & $\mathrm{X}$ & & & & & & $\mathrm{X}$ \\
\hline \multirow[t]{8}{*}{ Gastropoda } & Aplysiopsis enteromorphae & Species & $X$ & & & & & & & & & & & \\
\hline & Haminoeidae & Family & & & & $X$ & & & & & & & & \\
\hline & Heterobranchia & Subclass & & & & & & & & & & & & $\mathrm{X}$ \\
\hline & Hydrobiidae & Family & & & & & & & & & $\mathrm{X}$ & $\mathrm{X}$ & & \\
\hline & Odostomia & Genus & & & & & & & & & $\mathrm{X}$ & & & \\
\hline & Philine & Genus & & & & $X$ & & $X$ & & & & & & \\
\hline & Potamopyrgus antipodarum & Species & & & & & & & & & $X$ & $X$ & & \\
\hline & Volvulella & Genus & & $\mathrm{X}$ & & & & & & & & & & \\
\hline Hutchinsoniellidae & Lightiella serendipita & Species & & & $\mathrm{X}$ & $X$ & & & & & & & & \\
\hline Insecta & Corixidae & Family & & & $\mathrm{X}$ & & & & & & & & & \\
\hline
\end{tabular}


Table 7. Macroinvertebrate taxa identified in shallow (0-4 centimeters [cm];) cores from dredged (D) and undredged (U) locations at six sites-Mooring Road (MR), Richardson Bay (RB), Paradise Cay (PC), Strawberry Channel (SC), Loch Lomond (LL), and Yacht Harbor (YH)—in San Francisco Bay, California.-Continued

[In some cases, we identified to broader taxa (such as family) when pieces of organisms were encountered or when organisms were too small for distinguishing identifying features. Broader taxonomic categories are not included in total taxa count if they were represented by lower taxonomic identification (ID)]

\begin{tabular}{|c|c|c|c|c|c|c|c|c|c|c|c|c|c|c|}
\hline \multirow{2}{*}{ Broad taxonomic group } & \multirow{2}{*}{ Lowest taxonomic ID } & \multirow{2}{*}{$\begin{array}{l}\text { Taxonomic } \\
\text { rank }\end{array}$} & \multicolumn{2}{|c|}{ MR } & \multicolumn{2}{|c|}{ RB } & \multicolumn{2}{|c|}{ PC } & \multicolumn{2}{|c|}{ SC } & \multicolumn{2}{|c|}{ LL } & \multicolumn{2}{|c|}{ YH } \\
\hline & & & D & $\mathbf{U}$ & D & $\mathbf{U}$ & D & $\mathbf{U}$ & D & $\mathbf{U}$ & D & $\mathbf{U}$ & D & $\mathbf{U}$ \\
\hline \multirow[t]{3}{*}{ Isopoda } & Gnorimosphaeroma oregonense & Species & & & & & & & & $\mathrm{X}$ & & & & \\
\hline & Paranthura japonica & Species & & $\mathrm{X}$ & $\mathrm{X}$ & $\mathrm{X}$ & & $\mathrm{X}$ & & $\mathrm{X}$ & & $\mathrm{X}$ & & \\
\hline & Synidotea & Genus & & & & & & & & $\mathrm{X}$ & & & & \\
\hline Nemertea & Nemertea & Phylum & & & $\mathrm{X}$ & $\mathrm{X}$ & & $\mathrm{X}$ & $\mathrm{X}$ & $X$ & & & & $\mathrm{X}$ \\
\hline Oligochaeta & Oligochaeta & Subclass & $\mathrm{X}$ & $\mathrm{X}$ & $\mathrm{X}$ & $\mathrm{X}$ & $\mathrm{X}$ & $\mathrm{X}$ & $\mathrm{X}$ & $X$ & $\mathrm{X}$ & $\mathrm{X}$ & $\mathrm{X}$ & $\mathrm{X}$ \\
\hline Ophiuroidea & Ophiuroidea & Class & & & $\mathrm{X}$ & & & & & & & & & \\
\hline Osteichthyes & Osteichthyes & Superclass & & & & $\mathrm{X}$ & $\mathrm{X}$ & & & $\mathrm{X}$ & & & & \\
\hline Pantopoda & Pantopoda & Order & & & $\mathrm{X}$ & & & & & & & & & \\
\hline Porifera & Porifera & Phylum & & & $\mathrm{X}$ & $\mathrm{X}$ & & & & & & & & \\
\hline \multirow[t]{13}{*}{ Polychaeta (Errantia) } & Alitta & Genus & & $\mathrm{X}$ & & $\mathrm{X}$ & & & & & & $\mathrm{X}$ & & \\
\hline & Dorvillea & Genus & & & $\mathrm{X}$ & $\mathrm{X}$ & $\mathrm{X}$ & & & $\mathrm{X}$ & & & & $\mathrm{X}$ \\
\hline & Eteone & Genus & & $\mathrm{X}$ & $\mathrm{X}$ & $\mathrm{X}$ & $\mathrm{X}$ & $\mathrm{X}$ & $\mathrm{X}$ & $\mathrm{X}$ & $\mathrm{X}$ & $\mathrm{X}$ & & $\mathrm{X}$ \\
\hline & Exogone lourei & Species & $\mathrm{X}$ & $\mathrm{X}$ & $\mathrm{X}$ & $\mathrm{X}$ & $\mathrm{X}$ & $\mathrm{X}$ & $\mathrm{X}$ & $\mathrm{X}$ & $\mathrm{X}$ & $\mathrm{X}$ & & $\mathrm{X}$ \\
\hline & Glycinde & Genus & & $\mathrm{X}$ & $\mathrm{X}$ & $\mathrm{X}$ & $\mathrm{X}$ & $\mathrm{X}$ & & $\mathrm{X}$ & & $\mathrm{X}$ & $\mathrm{X}$ & $\mathrm{X}$ \\
\hline & Harmothoe imbricate & Species & & & & $\mathrm{X}$ & & & & & & & & \\
\hline & Hypereteone lighti & Species & & $\mathrm{X}$ & $\mathrm{X}$ & $\mathrm{X}$ & & & $\mathrm{X}$ & $\mathrm{X}$ & $\mathrm{X}$ & $\mathrm{X}$ & & $\mathrm{X}$ \\
\hline & Pettiboneia pugettensis & Species & & & & $\mathrm{X}$ & & & & & & & & \\
\hline & Schistomeringos annulata & Species & & & $\mathrm{X}$ & $\mathrm{X}$ & & $\mathrm{X}$ & & $\mathrm{X}$ & & & & \\
\hline & Schistomeringos longicornis & Species & & & & $\mathrm{X}$ & & & & & & & & \\
\hline & Sphaerosyllis californiensis & Species & & $\mathrm{X}$ & & & & & & & & & & \\
\hline & Syllidae & Family & & & $\mathrm{X}$ & & $\mathrm{X}$ & & & $\mathrm{X}$ & $\mathrm{X}$ & $\mathrm{X}$ & $\mathrm{X}$ & $\mathrm{X}$ \\
\hline & Syllis nipponica & Species & & & & $\mathrm{X}$ & & $\mathrm{X}$ & & & & & & \\
\hline \multirow[t]{7}{*}{ Polychaeta (Sedentaria) } & Armandia brevis & Species & & & $\mathrm{X}$ & & $\mathrm{X}$ & $\mathrm{X}$ & & & & & & $\mathrm{X}$ \\
\hline & Capitella capitata & Species & & $\mathrm{X}$ & $\mathrm{X}$ & $\mathrm{X}$ & & & $\mathrm{X}$ & $\mathrm{X}$ & & & & $\mathrm{X}$ \\
\hline & Capitellidae & Family & $\mathrm{X}$ & $\mathrm{X}$ & $\mathrm{X}$ & $\mathrm{X}$ & $\mathrm{X}$ & $\mathrm{X}$ & $\mathrm{X}$ & $\mathrm{X}$ & $\mathrm{X}$ & $\mathrm{X}$ & & $\mathrm{X}$ \\
\hline & Chaetozone & Genus & & & & & $\mathrm{X}$ & & & & & & & \\
\hline & Chone gracilis & Species & & & $\mathrm{X}$ & & & & & & & & & \\
\hline & Cirratulidae & Family & $\mathrm{X}$ & $\mathrm{X}$ & $\mathrm{X}$ & $\mathrm{X}$ & $\mathrm{X}$ & $X$ & & & $X$ & $\mathrm{X}$ & $\mathrm{X}$ & \\
\hline & Cirratulus dillonensis & Species & & & & $\mathrm{X}$ & & & & & & & & \\
\hline
\end{tabular}


Table 7. Macroinvertebrate taxa identified in shallow (0-4 centimeters [cm];) cores from dredged (D) and undredged (U) locations at six sites-Mooring Road (MR), Richardson Bay (RB), Paradise Cay (PC), Strawberry Channel (SC), Loch Lomond (LL), and Yacht Harbor (YH) - in San Francisco Bay, California._-Continued

[In some cases, we identified to broader taxa (such as family) when pieces of organisms were encountered or when organisms were too small for distinguishing identifying features. Broader taxonomic categories are not included in total taxa count if they were represented by lower taxonomic identification (ID)]

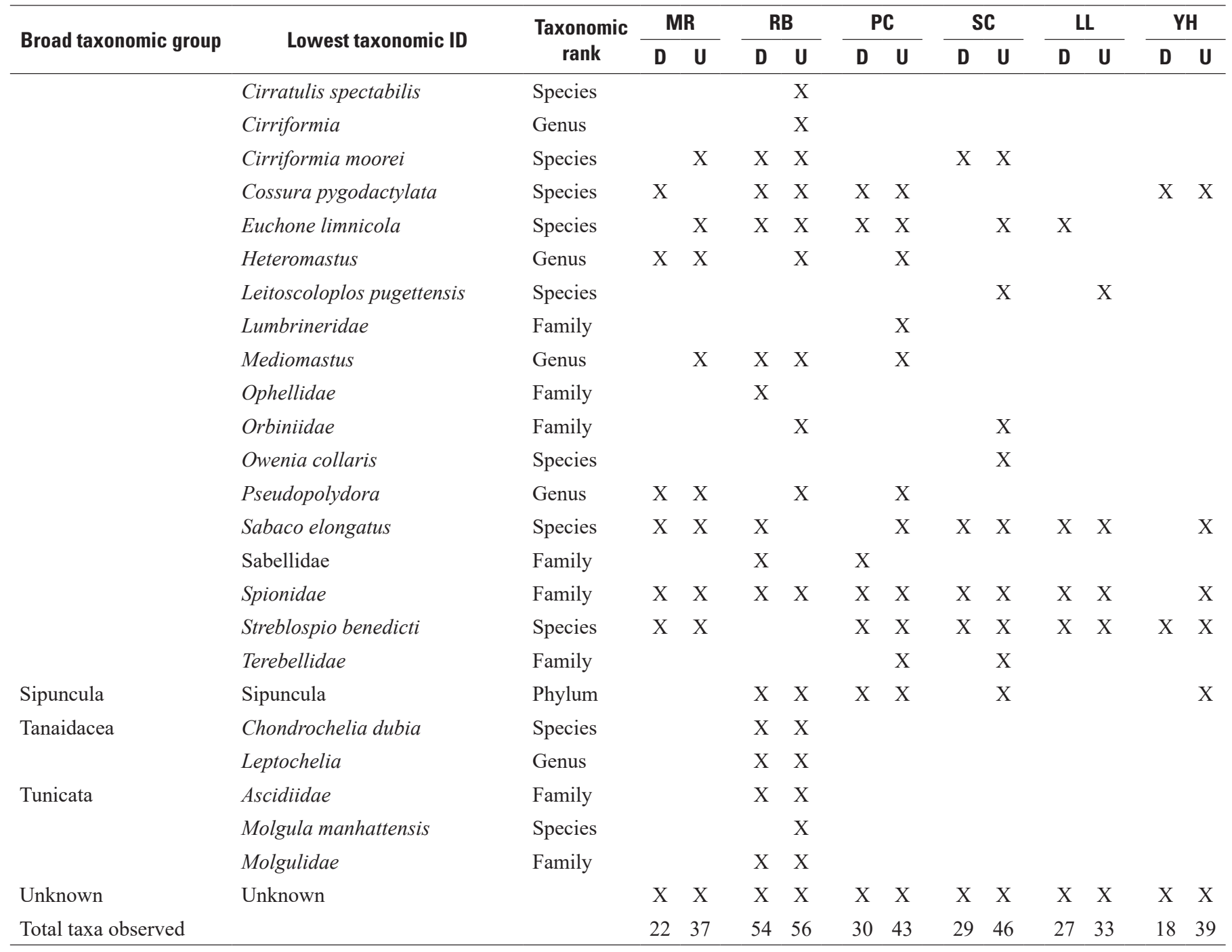


Table 8. Macroinvertebrate taxa identified in deep (4-10 centimeters [cm]) cores from dredged (D) and undredged (U) locations at six sites-Mooring Road (MR), Richardson Bay (RB), Paradise Cay (PC), Strawberry Channel (SC), Loch Lomond (LL), and Yacht Harbor $(\mathrm{YH})$ - in San Francisco Bay, California.

[In some cases, we identified to broader taxa (such as family) when pieces of organisms were encountered or when organisms were too small for distinguishing identifying features. Broader taxonomic categories are not included in total taxa count if they were represented by lower taxonomic identification (ID)]

\begin{tabular}{|c|c|c|c|c|c|c|c|c|c|c|c|c|c|c|}
\hline \multirow{2}{*}{ Broad taxonomic group } & \multirow{2}{*}{ Lowest taxonomic ID } & \multirow{2}{*}{$\begin{array}{l}\text { Taxonomic } \\
\text { rank }\end{array}$} & \multicolumn{2}{|c|}{ MR } & \multicolumn{2}{|c|}{ RB } & \multicolumn{2}{|c|}{ PC } & \multicolumn{2}{|c|}{ SC } & \multicolumn{2}{|c|}{ LL } & \multicolumn{2}{|c|}{ YH } \\
\hline & & & D & U & D & $\mathbf{U}$ & D & $\mathbf{U}$ & D & $\mathbf{U}$ & D & $\mathbf{U}$ & D & U \\
\hline Actiniaria & Actiniaria & Order & & & & & & & & & & & $\mathrm{X}$ & \\
\hline \multirow[t]{4}{*}{ Amphipoda } & Ampelisca abdita & Species & & & $\mathrm{x}$ & & $\mathrm{X}$ & $\mathrm{X}$ & & $\mathrm{X}$ & & & $\mathrm{X}$ & \\
\hline & Corophiidae & Family & & & $\mathrm{x}$ & & & & & & & & & \\
\hline & Grandidierella japonica & Species & & & $\mathrm{X}$ & & & $\mathrm{X}$ & & & & & & $\mathrm{X}$ \\
\hline & Monocorophium & Genus & $\mathrm{X}$ & & $\mathrm{X}$ & $\mathrm{X}$ & & & & & & & & \\
\hline Annelida & Annelida & Phylum & & & & & & & & & & & $\mathrm{X}$ & \\
\hline \multirow[t]{2}{*}{ Bacillariophyceae } & Bacillariophyceae & Order & & & & & & $\mathrm{X}$ & $\mathrm{X}$ & & & & & \\
\hline & Coscinodiscales & Order & & & & & & $\mathrm{X}$ & & & & & & \\
\hline \multirow[t]{3}{*}{ Bivalvia } & Arcuatula senhousia & Species & & $\mathrm{X}$ & & & $\mathrm{X}$ & & & & & & & $\mathrm{X}$ \\
\hline & Gemma gemma & Species & $\mathrm{X}$ & $\mathrm{X}$ & & & & & & & & & & \\
\hline & Macoma petalum & Species & & $\mathrm{X}$ & & & & & $\mathrm{X}$ & & $\mathrm{X}$ & & & \\
\hline Bryozoa & Bryozoa & Phylum & & & $\mathrm{X}$ & $\mathrm{X}$ & $\mathrm{X}$ & $\mathrm{X}$ & & $\mathrm{X}$ & & $\mathrm{X}$ & $\mathrm{X}$ & $\mathrm{X}$ \\
\hline Copepoda & Copepoda & Subclass & & & & & & $\mathrm{X}$ & $\mathrm{X}$ & $\mathrm{X}$ & & & & \\
\hline Crustacea & Crustacea & Subphylum & & & & & & & & & $\mathrm{X}$ & & & \\
\hline Cumacea & Nippoleucon hinumensis & Species & $\mathrm{X}$ & $\mathrm{X}$ & $\mathrm{X}$ & $\mathrm{X}$ & $\mathrm{X}$ & $\mathrm{X}$ & $\mathrm{X}$ & $\mathrm{X}$ & $\mathrm{X}$ & $\mathrm{X}$ & $\mathrm{X}$ & $\mathrm{X}$ \\
\hline Gastropoda & Gastropoda & Class & & & $\mathrm{X}$ & & & & & & & & & \\
\hline Hirudinea & Hirudinea & Subclass & & & $\mathrm{X}$ & & & & & & & & & \\
\hline Hutchinsoniellidae & Lightiella serendipita & Species & & & & $\mathrm{X}$ & & $\mathrm{X}$ & & & & & & $\mathrm{X}$ \\
\hline Insecta & Corixidae & Family & & & & & & & $\mathrm{X}$ & & & & & \\
\hline Isopoda & Paranthura japonica & Species & $\mathrm{X}$ & & $\mathrm{X}$ & $\mathrm{X}$ & & & $\mathrm{X}$ & & $\mathrm{X}$ & & & \\
\hline Leptostraca & Nebalia & Genus & & & & $\mathrm{X}$ & & & $\mathrm{X}$ & $\mathrm{X}$ & & & & \\
\hline Nematoda & Nematoda & Phylum & & $\mathrm{X}$ & $\mathrm{X}$ & $\mathrm{X}$ & $\mathrm{X}$ & $\mathrm{X}$ & $\mathrm{X}$ & $\mathrm{X}$ & $\mathrm{X}$ & $\mathrm{X}$ & $\mathrm{X}$ & $\mathrm{X}$ \\
\hline Oligochaeta & Oligochaeta & Subclass & $\mathrm{X}$ & $\mathrm{X}$ & $\mathrm{X}$ & $\mathrm{X}$ & $\mathrm{X}$ & $\mathrm{X}$ & $\mathrm{X}$ & $\mathrm{X}$ & $\mathrm{X}$ & $\mathrm{X}$ & $\mathrm{X}$ & $\mathrm{X}$ \\
\hline Osteichthyes & Osteichthyes & Superclass & & & & & & & & $\mathrm{X}$ & $\mathrm{X}$ & & & $\mathrm{X}$ \\
\hline Ostracoda & Myodocopida & Order & $\mathrm{X}$ & & & & & & & & & & & $\mathrm{X}$ \\
\hline Pantopoda & Pantopoda & Order & & & $\mathrm{x}$ & & & & & & & & & \\
\hline \multirow[t]{5}{*}{ Polychaeta (Errantia) } & Alitta & Genus & & $\mathrm{X}$ & & & & & & & & & & \\
\hline & Exogone lourei & Species & & & & & & & & $\mathrm{X}$ & & & & \\
\hline & Glycinde & Genus & & & $\mathrm{X}$ & & & & & & & & & $\mathrm{X}$ \\
\hline & Megasyllis nipponica & Species & & & & $\mathrm{X}$ & & & & & & & & \\
\hline & Schistomeringos longicornis & Species & & & & $\mathrm{X}$ & & & & & & & & \\
\hline \multirow[t]{8}{*}{ Polychaeta (Sedentaria) } & Capitella capitata & Species & & & & $\mathrm{X}$ & & & & & & & & $\mathrm{X}$ \\
\hline & Capitellidae & Family & & $\mathrm{X}$ & $\mathrm{X}$ & & & & $\mathrm{X}$ & $\mathrm{X}$ & & $\mathrm{X}$ & & $\mathrm{X}$ \\
\hline & Cirratulidae & Family & & $\mathrm{X}$ & & $\mathrm{X}$ & & & & & & & & \\
\hline & Cirratulus dillonensis & Species & & & & $\mathrm{X}$ & & & & & & & & \\
\hline & Cirriformia & Genus & & & & $\mathrm{X}$ & & & & & & & & \\
\hline & Cirriformia moorei & Species & & & $\mathrm{X}$ & $\mathrm{X}$ & & & & $\mathrm{X}$ & & & & \\
\hline & Cossura pygodactylata & Species & $\mathrm{X}$ & & $\mathrm{X}$ & $\mathrm{X}$ & $\mathrm{x}$ & $\mathrm{X}$ & & & & & $\mathrm{X}$ & $\mathrm{X}$ \\
\hline & Leitoscoloplos pugettensis & Species & & & & & & & & $\mathrm{X}$ & & & & \\
\hline
\end{tabular}


Table 8. Macroinvertebrate taxa identified in deep (4-10 centimeters [cm]) cores from dredged (D) and undredged (U) locations at six sites-Mooring Road (MR), Richardson Bay (RB), Paradise Cay (PC), Strawberry Channel (SC), Loch Lomond (LL), and Yacht Harbor (YH)_in San Francisco Bay, California.-Continued

[In some cases, we identified to broader taxa (such as family) when pieces of organisms were encountered or when organisms were too small for distinguishing identifying features. Broader taxonomic categories are not included in total taxa count if they were represented by lower taxonomic identification (ID)]

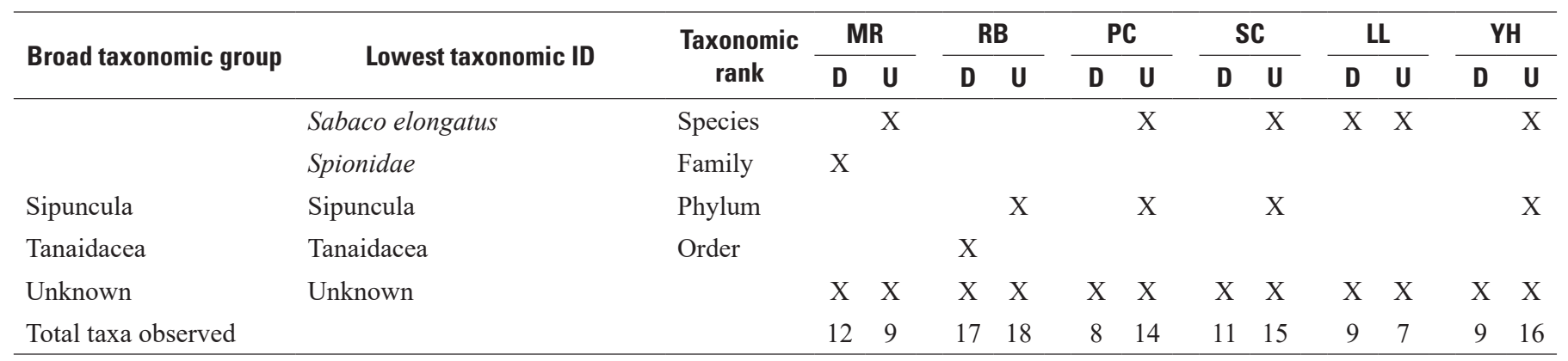

\section{Dredged in 2014}

Macroinvertebrate density was 53 percent less in undredged areas than in dredged areas (table 9) at Paradise Cay. Polychaetes were dominant in dredged areas (72 percent), which also contained amphipods (17 percent). This differed from the undredged area at this site, which was dominated by amphipods ( 60 percent) and had notably fewer polychaetes (18 percent; fig. 24). Macroinvertebrate communities in the undredged area at Paradise Cay had the greatest density and percentage of amphipods relative to other sites. Biomass values in the dredged and undredged areas at Paradise Cay were similar $\left(13.3 \mathrm{~g} / \mathrm{m}^{2}\right.$ dry weight [ $\left.\mathrm{dw}\right]$ in dredged area versus $13.8 \mathrm{~g} / \mathrm{m}^{2} \mathrm{dw}$ in undredged area; table 9). In the dredged area, polychaetes accounted for 72 percent of the biomass, while bivalves accounted for 24 percent; in the undredged area, polychaetes accounted for 28 percent of the biomass, while bivalves accounted for 59 percent (fig. 25). Overall, the dredged area provided 49 percent more energy than the undredged area (table 9), with polychaetes providing 98 percent of the energy in the dredged area versus 58 percent in the undredged area (fig. 26).

Strawberry Channel macroinvertebrate densities in undredged areas were 136 percent greater than in dredged areas (table 9). Communities within the dredged areas at this site primarily consisted of polychaetes (38 percent), oligochaetes (23 percent dredged), and nematodes (13 percent). In the undredged areas, polychaetes (38 percent), oligochaetes ( 22 percent), and amphipods (20 percent) were the most abundant taxa (fig. 24). Strawberry Channel macroinvertebrate communities had the greatest percentage of oligochaetes at dredged and undredged areas relative to other sites. Biomass in the dredged and undredged areas at
Strawberry Channel were similar $\left(28.8 \mathrm{~g} / \mathrm{m}^{2} \mathrm{dw}\right.$ in dredged area versus $31.1 \mathrm{~g} / \mathrm{m}^{2} \mathrm{dw}$ in undredged area; table 9). In the dredged area, bivalves accounted for 96 percent of the biomass; in the undredged area, however, polychaetes accounted for 19 percent of the biomass, while bivalves accounted for 79 percent (fig. 25). The undredged area provided 77 percent more energy than the dredged area (table 9). Polychaetes provided 54 percent of available energy in the undredged area, while bivalves supplied 41 percent and other taxa comprised the additional 5 percent. Bivalves provided 82 percent of available energy at the dredged area and polychaetes the remaining 18 percent (fig. 26).

\section{Dredged in 2015}

At Loch Lomond, macroinvertebrate densities in the undredged area were 219 percent greater than in the dredged area; the average density in the dredged area was the lowest among all the sites (table 9). Dominant taxa in the dredged area included polychaetes ( 24 percent), oligochaetes (18 percent), and nematodes (18 percent); the undredged area consisted mainly of polychaetes (32 percent), nematodes (22 percent), and amphipods (20 percent). Biomass at Loch Lomond was 171 percent greater in the undredged areas than in the dredged areas (table 9). In the dredged area, bivalves accounted for 90 percent of the biomass; in the undredged area, however, polychaetes accounted for 41 percent of the biomass, while bivalves accounted for 58 percent. Likewise, macroinvertebrate energy content in the undredged area was 475 percent greater than in the dredged area, with polychaetes contributing 79 percent and bivalves 21 percent of the energy in the undredged area (fig. 26). 


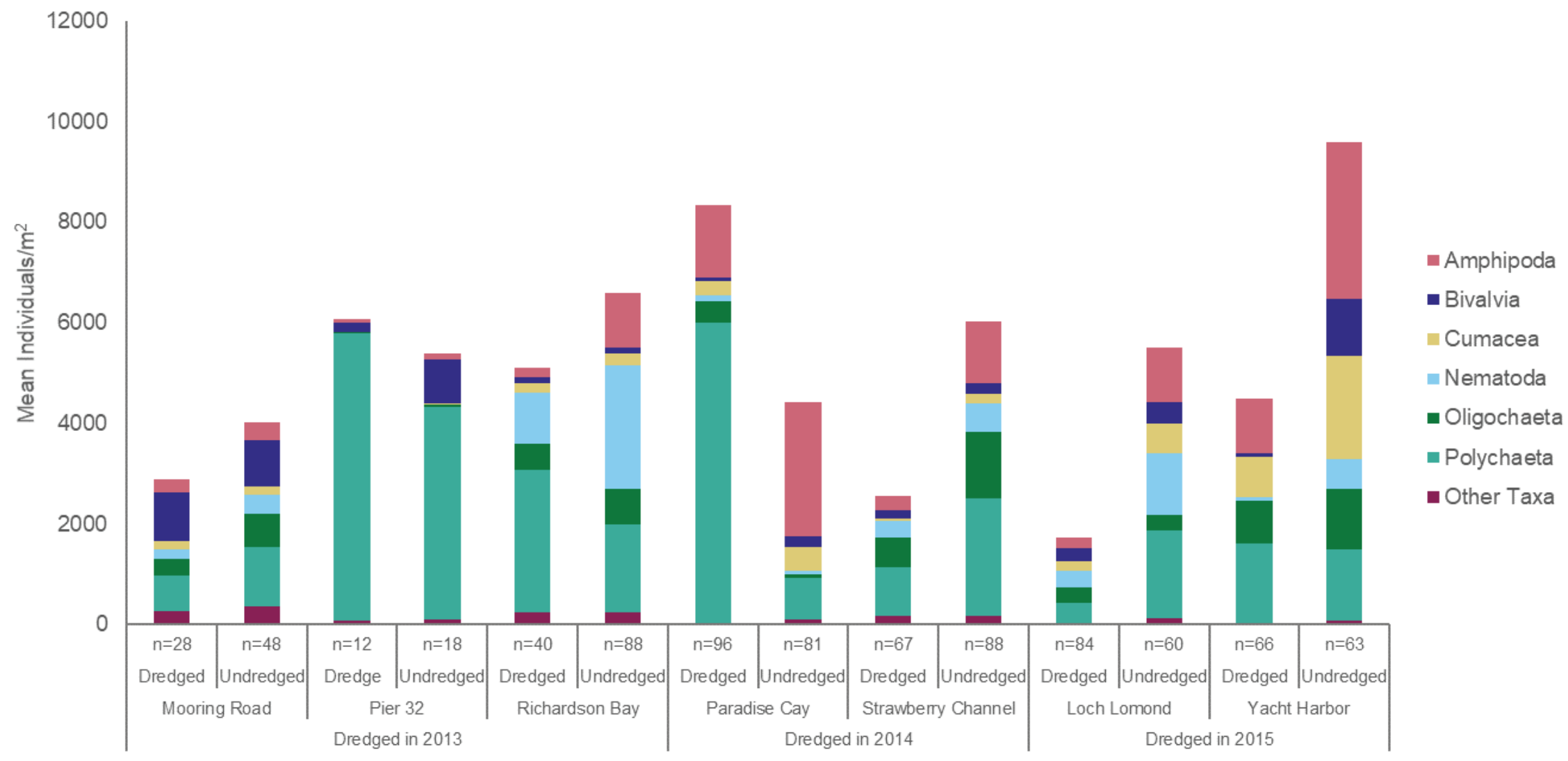

Figure 24. Mean densities (individuals/ square meter [ $\left.\mathrm{m}^{2}\right]$ to 10 centimeter [ $\left.\mathrm{cm}\right]$ depth) of macroinvertebrate taxa in dredged and undredged areas at seven sites (Mooring Road, Pier 32, Richardson Bay, Paradise Cay, Strawberry Channel, Loch Lomond, and Yacht Harbor) in San Francisco Bay. Cores were collected at Pier 32 during the pilot study (November 2015); at Mooring Road, Richardson Bay, Paradise Cay, and Strawberry Channel during the pilot and full studies (November 2015, August 2016, January 2017, August 2017); and at Loch Lomond and Yacht Harbor during the full study (August 2016, January 2017, August 2017). 

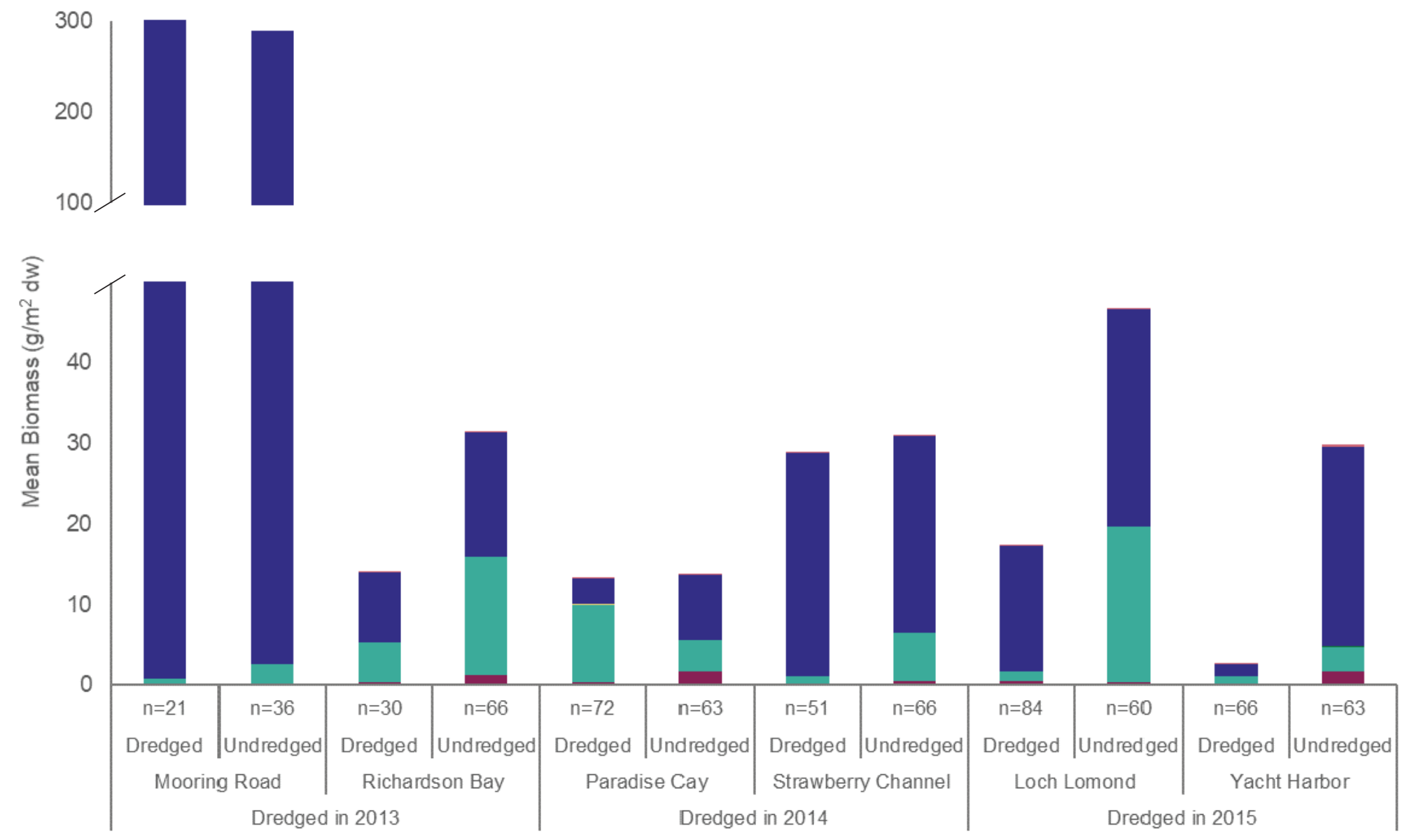

- Amphipoda

- Bivalvia

- Cumacea

- Oligochaeta

- Polychaeta

- Other Taxa

Figure 25. Mean biomass (grams per square meter $[\mathrm{g} / \mathrm{m} 2]$ to 10 centimeter $[\mathrm{cm}]$ depth) of macroinvertebrate taxa in dredged and undredged areas at six sites (Mooring Road, Richardson Bay, Paradise Cay, Strawberry Channel, Loch Lomond, and Yacht Harbor) in San Francisco Bay. Cores were collected at all sites during the full study (August 2016, January 2017, August 2017). 


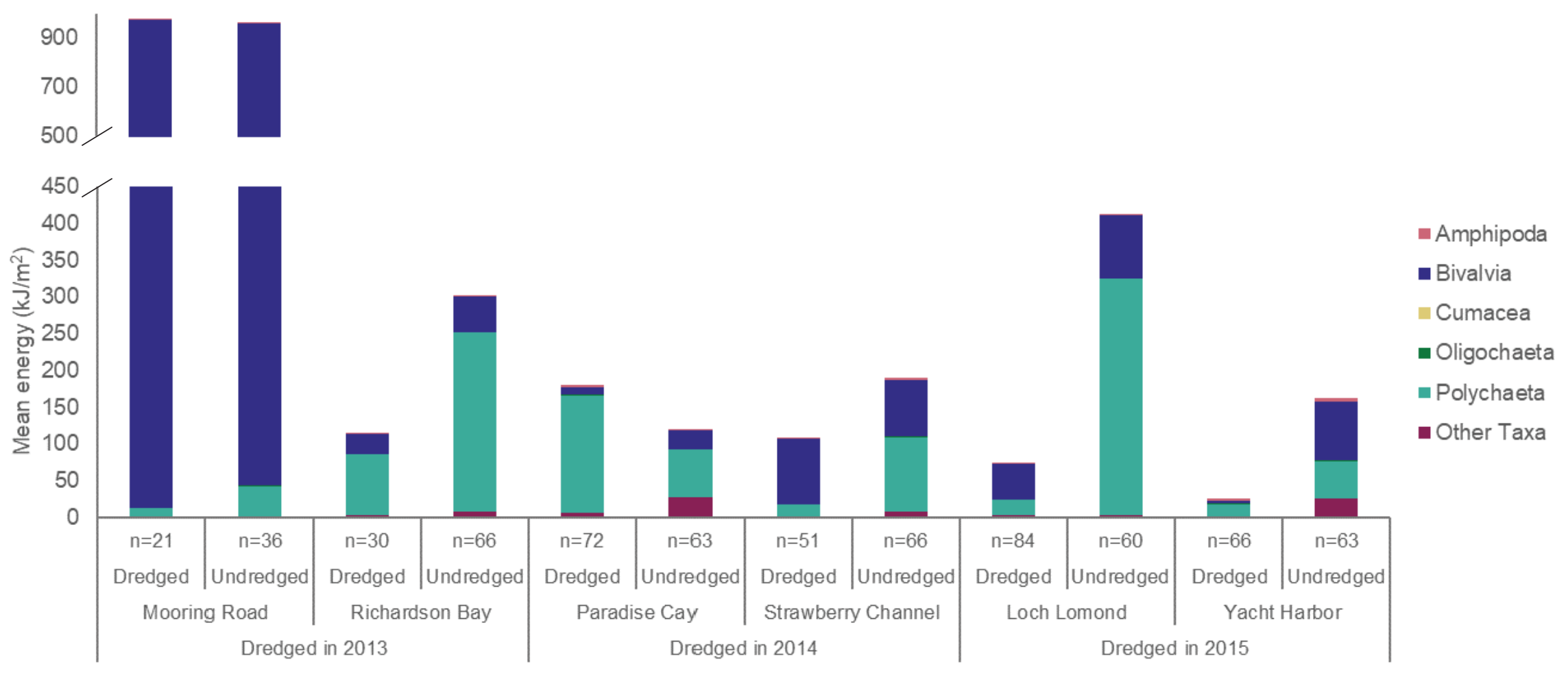

Figure 26. Mean energy (kilojoule per square meter $\left[\mathrm{kJ} / \mathrm{m}^{2}\right]$ to 10 centimeter $[\mathrm{cm}]$ depth) of macroinvertebrate taxa in dredged and undredged areas at six sites (Mooring Road, Richardson Bay, Paradise Cay, Strawberry Channel, Loch Lomond, and Yacht Harbor) in San Francisco Bay. Cores were collected at all sites during the full study (August 2016, January 2017, August 2017). 
Table 9. Comparison of mean ( \pm standard error) macroinvertebrate density (number of individuals/square meter [m²]), biomass (grams $[\mathrm{g}] / \mathrm{m}^{2}$ ) in dry weight $(\mathrm{dw})$, and energy (kilojoules per square meter $\left.\left[\mathrm{kJ} / \mathrm{m}^{2}\right]\right)$ in dredged and undredged areas during the pilot and full study in each site.

[The number of cores taken at each site during each sampling period is given $(\mathrm{N})]$

\begin{tabular}{|c|c|c|c|c|c|c|c|c|}
\hline \multirow[b]{2}{*}{ Site } & \multicolumn{4}{|c|}{ Dredged } & \multicolumn{4}{|c|}{ Undredged } \\
\hline & $\mathbf{N}$ & $\begin{array}{c}\text { Mean density } \\
\text { (individuals/m²) }\end{array}$ & $\begin{array}{c}\text { Mean biomass } \\
\left(\mathrm{g} / \mathrm{m}^{2} \mathrm{dw}\right)\end{array}$ & $\begin{array}{c}\text { Mean energy } \\
\left(\mathrm{kJ} / \mathrm{m}^{2}\right)\end{array}$ & $\mathbf{N}$ & $\begin{array}{c}\text { Mean density } \\
\text { (individuals/m²) }\end{array}$ & $\begin{array}{l}\text { Mean biomass } \\
\left(\mathrm{g} / \mathrm{m}^{2} \mathrm{dw}\right)\end{array}$ & $\begin{array}{c}\text { Mean energy } \\
\left(\mathrm{kJ} / \mathrm{m}^{2}\right)\end{array}$ \\
\hline \multicolumn{9}{|c|}{ November 2015 (Pilot) } \\
\hline Pier 32 & 12 & $6247.4 \pm 1331.4$ & - & & 18 & $5208.8 \pm 881.6$ & - & \\
\hline Mooring Road & 7 & $1164.7 \pm 389.6$ & - & & 12 & $1321.7 \pm 451.6$ & - & \\
\hline Richardson Bay & 20 & $2818.5 \pm 559.6$ & - & & 13 & $7520.9 \pm 1903.7$ & - & \\
\hline Paradise Cay & 24 & $5146.0 \pm 1235.7$ & - & & 21 & $8135.3 \pm 901.9$ & - & \\
\hline Strawberry Channel & 17 & $1502.5 \pm 497.7$ & - & & 22 & $1757.4 \pm 356.2$ & - & \\
\hline \multicolumn{9}{|c|}{ August 2016} \\
\hline Mooring Road & 7 & $6475.6 \pm 597.8$ & $559.49 \pm 62.45$ & $1791.5 \pm 199.2$ & 12 & $8929.0 \pm 920.9$ & $551.57 \pm 101.57$ & $1828.4 \pm 327.8$ \\
\hline Richardson Bay & 10 & $4526.6 \pm 671.5$ & $12.26 \pm 2.89$ & $187.4 \pm 49.6$ & 22 & $8661.3 \pm 2665.6$ & $17.12 \pm 3.22$ & $251.4 \pm 41.3$ \\
\hline Paradise Cay & 24 & $4995.1 \pm 935.5$ & $0.57 \pm 0.11$ & $8.5 \pm 1.3$ & 21 & $1658.3 \pm 449.0$ & $6.82 \pm 2.08$ & $90.1 \pm 20.3$ \\
\hline Strawberry Channel & 17 & $3115.8 \pm 729.3$ & $5.84 \pm 3.87$ & $42.2 \pm 16.6$ & 22 & $2743.4 \pm 423.8$ & $2.75 \pm 0.33$ & $46.7 \pm 5.5$ \\
\hline Loch Lomond & 28 & $1337.0 \pm 178.5$ & $3.92 \pm 1.75$ & $20.7 \pm 6.9$ & 20 & $5838.1 \pm 897.5$ & $27.38 \pm 4.58$ & $392.0 \pm 66.3$ \\
\hline Yacht Harbor & 22 & $3828.6 \pm 604.3$ & $1.14 \pm 0.33$ & $11.1 \pm 2.0$ & 21 & $8858.5 \pm 862.3$ & $6.75 \pm 1.44$ & $83.8 \pm 18.2$ \\
\hline \multicolumn{9}{|c|}{ January 2017} \\
\hline Mooring Road & 7 & $3046.8 \pm 258.2$ & $296.67 \pm 4.34$ & $959.5 \pm 138.9$ & 12 & $4552.0 \pm 979.6$ & $286.32 \pm 69.15$ & $945.4 \pm 224.2$ \\
\hline Richardson Bay & 10 & $9498.8 \pm 1758.1$ & $1.92 \pm 0.32$ & $30.1 \pm 5.1$ & 22 & $5209.0 \pm 1246.8$ & $28.72 \pm 5.15$ & $452.9 \pm 79.7$ \\
\hline Paradise Cay & 24 & $\begin{array}{r}11085.7 \pm \\
1319.6\end{array}$ & $1.06 \pm 0.14$ & $13.9 \pm 1.5$ & 21 & $2740.6 \pm 344.5$ & $4.17 \pm 0.76$ & $62.8 \pm 12.4$ \\
\hline Strawberry Channel & 17 & $2864.9 \pm 702.8$ & $2.22 \pm 1.22$ & $14.8 \pm 4.5$ & 22 & $\begin{array}{r}11129.8 \pm \\
1042.6\end{array}$ & $14.39 \pm 2.15$ & $241.9 \pm 35.5$ \\
\hline Loch Lomond & 28 & $1502.9 \pm 525.6$ & $0.50 \pm 0.10$ & $8.0 \pm 1.7$ & 20 & $4386.5 \pm 826.8$ & $35.20 \pm 12.12$ & $580.4 \pm 200.9$ \\
\hline Yacht Harbor & 22 & $4829.9 \pm 688.0$ & $0.81 \pm 0.17$ & $10.4 \pm 1.9$ & 21 & $6994.1 \pm 1444.9$ & $1.53 \pm 0.51$ & $17.4 \pm 7.9$ \\
\hline \multicolumn{9}{|c|}{ August 2017} \\
\hline Mooring Road & 7 & $645.7 \pm 98.7$ & $52.16 \pm 24.18$ & $179.9 \pm 76.6$ & 12 & $1299.8 \pm 192.8$ & $36.69 \pm 8.07$ & $123.8 \pm 25.8$ \\
\hline Richardson Bay & 10 & $2482.9 \pm 659.6$ & $27.82 \pm 12.51$ & $122.6 \pm 43.9$ & 22 & $7228.9 \pm 1567.9$ & $48.39 \pm 9.16$ & $203.5 \pm 32.6$ \\
\hline Paradise Cay & 24 & $9775.2 \pm 999.2$ & $38.39 \pm 5.72$ & $516.0 \pm 91.0$ & 21 & $5987.5 \pm 516.5$ & $30.45 \pm 6.52$ & $208.2 \pm 51.6$ \\
\hline Strawberry Channel & 17 & $2629.0 \pm 466.6$ & $78.48 \pm 15.26$ & $263.5 \pm 50.0$ & 22 & $8432.7 \pm 801.8$ & $75.81 \pm 17.62$ & $278.9 \pm 56.3$ \\
\hline Loch Lomond & 28 & $2342.0 \pm 269.6$ & $47.28 \pm 8.73$ & $191.1 \pm 31.0$ & 20 & $6315.6 \pm 959.9$ & $77.55 \pm 6.92$ & $265.0 \pm 22.1$ \\
\hline Yacht Harbor & 22 & $4844.3 \pm 615.8$ & $6.14 \pm 2.08$ & $53.4 \pm 9.5$ & 21 & $\begin{array}{r}12948.3 \pm \\
1033.5 \\
\end{array}$ & $81.33 \pm 15.91$ & $384.8 \pm 63.5$ \\
\hline \multicolumn{9}{|c|}{ All Sampling Periods } \\
\hline Mooring Road & 28 & $2878.57 \pm 477.2$ & $302.77 \pm 52.7$ & $977.0 \pm 167.7$ & 48 & $4012.22 \pm 569.9$ & $291.53 \pm 53.4$ & $965.9 \pm 174.4$ \\
\hline Richardson Bay & 40 & $5105.93 \pm 686.8$ & $14.00 \pm 4.6$ & $113.3 \pm 24.5$ & 88 & $6594.40 \pm 910.0$ & $31.41 \pm 3.9$ & $302.6 \pm 34.1$ \\
\hline Paradise Cay & 96 & $8329.50 \pm 713.6$ & $13.34 \pm 2.8$ & $179.5 \pm 41.1$ & 81 & $4416.47 \pm 396.2$ & $13.81 \pm 2.7$ & $120.4 \pm 20.2$ \\
\hline Strawberry Channel & 67 & $2554.20 \pm 298.2$ & $28.85 \pm 7.2$ & $106.9 \pm 23.3$ & 88 & $6017.07 \pm 545.4$ & $30.98 \pm 7.1$ & $189.2 \pm 25.3$ \\
\hline Loch Lomond & 84 & $1727.29 \pm 208.9$ & $17.23 \pm 3.7$ & $73.3 \pm 13.9$ & 60 & $5513.39 \pm 519.8$ & $46.71 \pm 5.6$ & $412.5 \pm 71.7$ \\
\hline Yacht Harbor & 66 & $4500.92 \pm 366.9$ & $2.70 \pm 0.8$ & $25.0 \pm 4.0$ & 63 & $9600.28 \pm 718.8$ & $29.87 \pm 7.0$ & $162.0 \pm 29.8$ \\
\hline
\end{tabular}

Yacht Harbor had the greatest average macroinvertebrate density out of all the undredged areas at sites $\left(9,600\right.$ individuals $\left./ \mathrm{m}^{2}\right)$; this was 113 percent greater than the density in the dredged area (4,501 individuals $/ \mathrm{m}^{2}$; table 9$)$. 
In the dredged area, polychaetes were the most abundant taxa (36 percent), followed by amphipods ( 24 percent) and oligochaetes (18 percent). In the undredged area, amphipods were the most abundant taxa, followed by cumaceans (21 percent) and polychaetes (15 percent). Biomass in the dredged area at Yacht Harbor was the lowest among all the sites $\left(2.7 \mathrm{~g} / \mathrm{m}^{2} \mathrm{dw}\right)$, while the biomass in the undredged area was 1007 percent greater $\left(29.9 \mathrm{~g} / \mathrm{m}^{2} \mathrm{dw}\right.$; table 9). Bivalves and polychaetes contributed the most biomass in both dredged (53 percent and 37 percent, respectively) and undredged areas (83 percent and 10 percent, respectively). Energy content was 548 percent greater in the undredged area compared to the dredged, and unlike other sites, this was driven mainly by bivalves (49 percent of total energy; fig. 26).

\section{The Effect of Dredging on Macroinvertebrate Density, Biomass, and Energy Content}

Total density of macroinvertebrate taxa was significantly greater in undredged areas compared to dredged areas for all size classes and depths (table 10). Macroinvertebrate density increased as salinity increased, decreased as elevation increased, and was greater during the winter than during the summer (table 10). The taxonomic composition of the benthic community differed among sampling periods with Polychaeta found in greatest densities during the November 2015 and January 2017 sampling periods, Nematoda found in the greatest densities during the August 2016 sampling period, and Amphipoda found in greatest densities during the August 2017 sampling period (fig. 27-30). Overall, the

Table 10. Summary of general linear mixed model (GLMM) results for total density of macroinvertebrates from different size classes found in shallow ( $0-4$ centimeters [ $[\mathrm{cm}])$ and deep $(0-10 \mathrm{~cm})$ cores at six sites (Loch Lomond, Mooring Road, Paradise Cay, Richardson Bay, Strawberry Channel, and Yacht Harbor) with dredged and undredged areas.

[Cores were collected during August 2016, January 2017, and August 2017. Collection site and transects were included in the GLMM as random effects. Orange indicates the relationship between density and the fixed effect was positive, and purple indicates that the relationship was negative. See full GLMM tables 1.1 to 1.5 in appendix for more information. Abbreviations: mm, millimeter; >, greater than; $<$, less than]

\begin{tabular}{|c|c|c|c|c|c|}
\hline \multirow{2}{*}{$\begin{array}{c}\text { Core depth } \\
\begin{array}{c}\text { Macroinvertebrate } \\
\text { size class }\end{array}\end{array}$} & \multicolumn{4}{|c|}{$0-4 \mathrm{~cm}$} & \multirow{2}{*}{$\begin{array}{l}0-10 \mathrm{~cm} \\
0-50 \mathrm{~mm}\end{array}$} \\
\hline & $\begin{array}{l}0-4 \\
\mathrm{~mm}\end{array}$ & $\begin{array}{c}>4-12 \\
\mathrm{~mm}\end{array}$ & $\begin{array}{c}>12-24 \\
\mathrm{~mm}\end{array}$ & $\begin{array}{c}>24-50 \\
\mathrm{~mm}\end{array}$ & \\
\hline Fixed effect & $p$ & $p$ & $p$ & $p$ & $p$ \\
\hline Intercept & $<0.001$ & $<0.001$ & $<0.001$ & 0.490 & $<0.001$ \\
\hline $\begin{array}{l}\text { Treatment: } \\
\text { undredged }\end{array}$ & $<0.001$ & $<0.001$ & $<0.001$ & 0.002 & $<0.001$ \\
\hline Season: winter & $<0.001$ & $<0.001$ & 0.005 & 0.484 & 0.024 \\
\hline Salinity & $<0.001$ & $<0.001$ & 0.120 & 0.507 & 0.023 \\
\hline Elevation & $<0.001$ & $<0.001$ & 0.019 & 0.271 & $<0.001$ \\
\hline
\end{tabular}

number of broad taxa and macroinvertebrate densities were much greater in shallow core fractions $(0-4 \mathrm{~cm})$ compared to deeper core fractions (4-10 cm; figs. 31-32). Polychaeta with a $0-4 \mathrm{~mm}$ head width was the most abundant taxon in shallow cores (fig. 31).

Total biomass of macroinvertebrate prey of all sizes $(0-50 \mathrm{~mm})$ in both surface $(0-4 \mathrm{~cm})$ and whole cores $(0-10 \mathrm{~cm})$ was consistently greater in undredged areas compared to dredged areas (table 11). We did not detect any clear effects of season, salinity, or elevation on biomass; the effects varied depending on the core depth and macroinvertebrate size class (table 11). Biomass of $0-50 \mathrm{~mm}$ macroinvertebrates in whole cores $(0-10 \mathrm{~cm})$ varied among sampling periods. Biomass was much greater at Mooring Road compared to all other sites during the August 2016 sampling period, and it was much greater at Richardson Bay compared to all other sites during the January 2017 sampling period (figs. 33-34). Biomass was more similar among sites during the August 2017 sampling period (fig. 35). At all sites, most of the available biomass was from Bivalvia followed by Polychaeta and was found near the surface $(0-4 \mathrm{~cm}$ deep; figs. 36-37). Bivalvia biomass was particularly high at Mooring Road during August 2016 and at Richardson Bay during January 2017 (figs. 33-34). Bivalvia near the surface (0-4 cm deep) in the 12-24 mm size class represented the greatest biomass at each site, followed by $4-12 \mathrm{~mm}$ and 24-50 mm Bivalvia near the surface and 12-24 mm Bivalvia in deeper sediments (4-10 cm deep; figs. 36-37). Polychaeta (0-4 mm head width) represented the taxa with the second greatest biomass in deeper sediments (fig. 37).

Table 11. Summary of general linear mixed model (GLMM) results for total biomass of macroinvertebrates from different size classes found in shallow (0-4 centimeters [cm]) and deep $(0-10 \mathrm{~cm}$ ) cores at six sites (Loch Lomond, Mooring Road, Paradise Cay, Richardson Bay, Strawberry Channel, and Yacht Harbor) within dredged and undredged areas.

[Cores were collected during summer and winter 2016-17. Collection site and transects were included in the GLMM as random effects. Orange indicates the relationship between density and the fixed effect was positive, and purple indicates that the relationship was negative. See full GLMM tables 1.7 to 1.11 in appendix for more information. Abbreviations: mm, millimeter; >, greater than; $<$, less than]

\begin{tabular}{|c|c|c|c|c|c|}
\hline Core depth & & & cm & & $0-10 \mathrm{~cm}$ \\
\hline $\begin{array}{l}\text { Macroinvertebrate } \\
\text { size class }\end{array}$ & $\begin{array}{l}0-4 \\
\mathrm{~mm}\end{array}$ & $\begin{array}{c}>4-12 \\
\mathrm{~mm}\end{array}$ & $\begin{array}{c}>12-24 \\
\mathrm{~mm}\end{array}$ & $\begin{array}{c}>24-50 \\
\mathrm{~mm}\end{array}$ & 0-50 mm \\
\hline Fixed effect & $p$ & $p$ & $p$ & $p$ & $p$ \\
\hline Intercept & $<0.001$ & $<0.001$ & $<0.001$ & $<0.001$ & $<0.001$ \\
\hline $\begin{array}{l}\text { Treatment: } \\
\text { undredged }\end{array}$ & $<0.001$ & $<0.001$ & 0.036 & 0.169 & $<0.001$ \\
\hline Season: winter & $<0.001$ & $<0.001$ & 0.006 & $<0.001$ & $<0.001$ \\
\hline Salinity & $<0.001$ & $<0.001$ & 0.112 & $<0.001$ & 0.012 \\
\hline Elevation & 0.003 & 0.417 & 0.002 & $<0.001$ & 0.002 \\
\hline
\end{tabular}




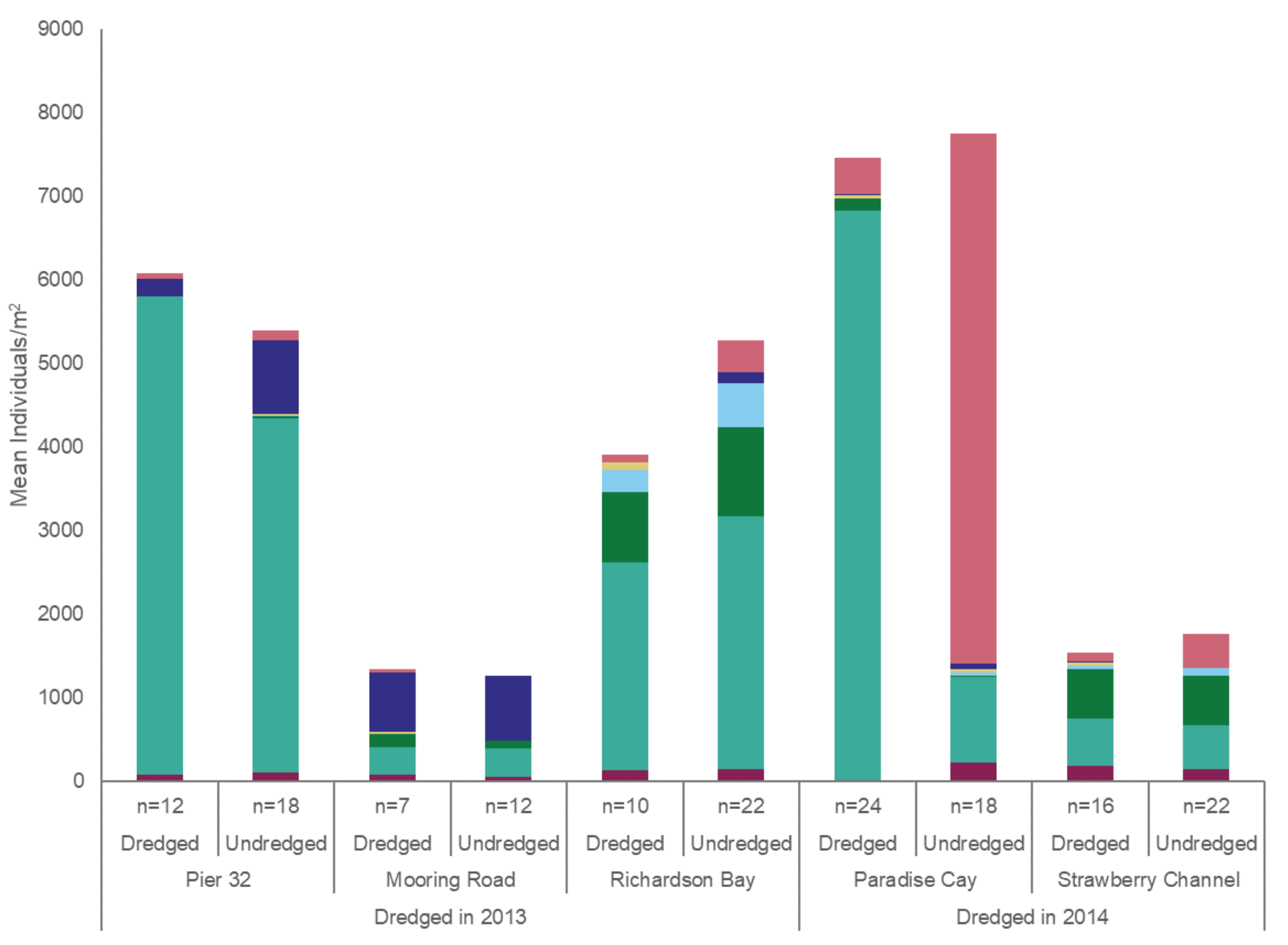

Figure 27. Mean densities (individuals/meter [m²] to 10 centimeter [cm] depth) of macroinvertebrate taxa collected in dredged and undredged areas at five pilot study sites (Pier 32, Mooring Road, Richardson Bay, Paradise Cay, and Strawberry Channel) in November 2015.

- Amphipoda

- Bivalvia

Cumacea

Nematoda

- Oligochaeta

- Polychaeta

- Other Taxa 


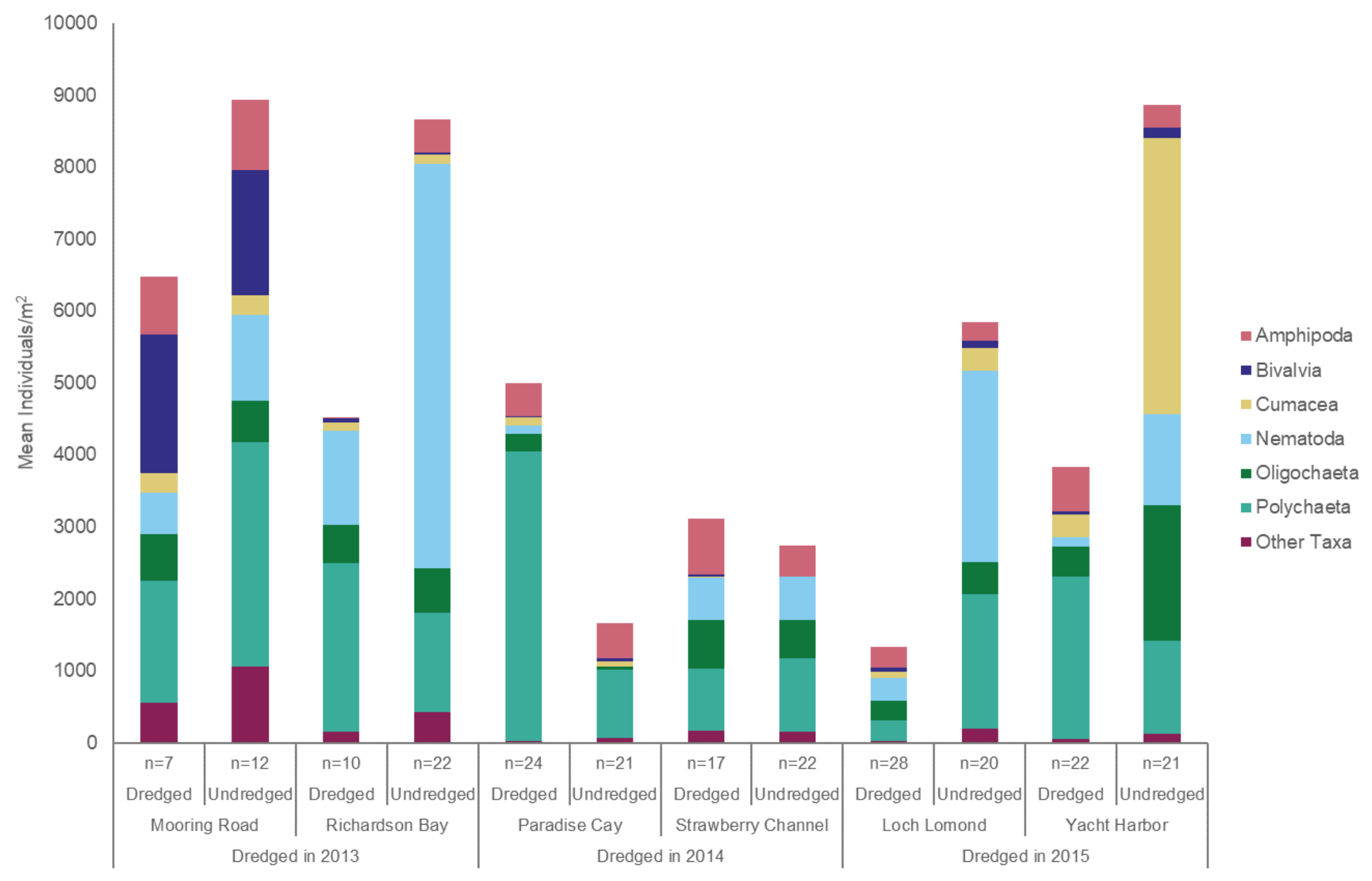

Figure 28. Mean densities (individuals/meter [ $\left.\mathrm{m}^{2}\right]$ to 10 centimeter [cm] depth) of macroinvertebrate taxa collected in dredged and undredged areas at six study sites (Mooring Road, Richardson Bay, Paradise Cay, Strawberry Channel, Loch Lomond, and Yacht Harbor) in August 2016. 


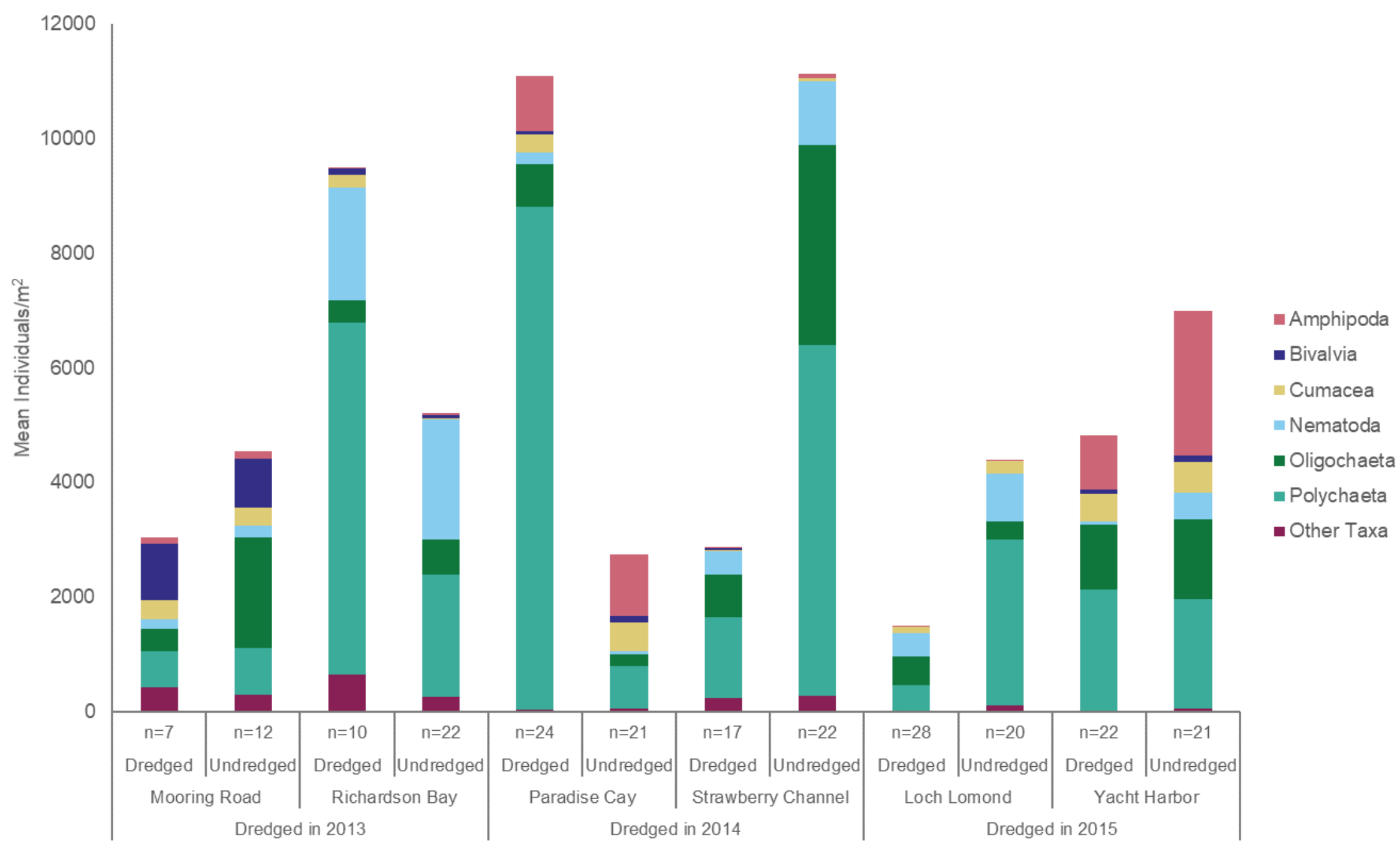

Figure 29. Mean densities (individuals/ meter [ $\left.\mathrm{m}^{2}\right]$ to 10 centimeter $[\mathrm{cm}]$ depth) of macroinvertebrate taxa collected in dredged and undredged areas at six study sites (Mooring Road, Richardson Bay, Paradise Cay, Strawberry Channel, Loch Lomond, and Yacht Harbor) in January 2017. 


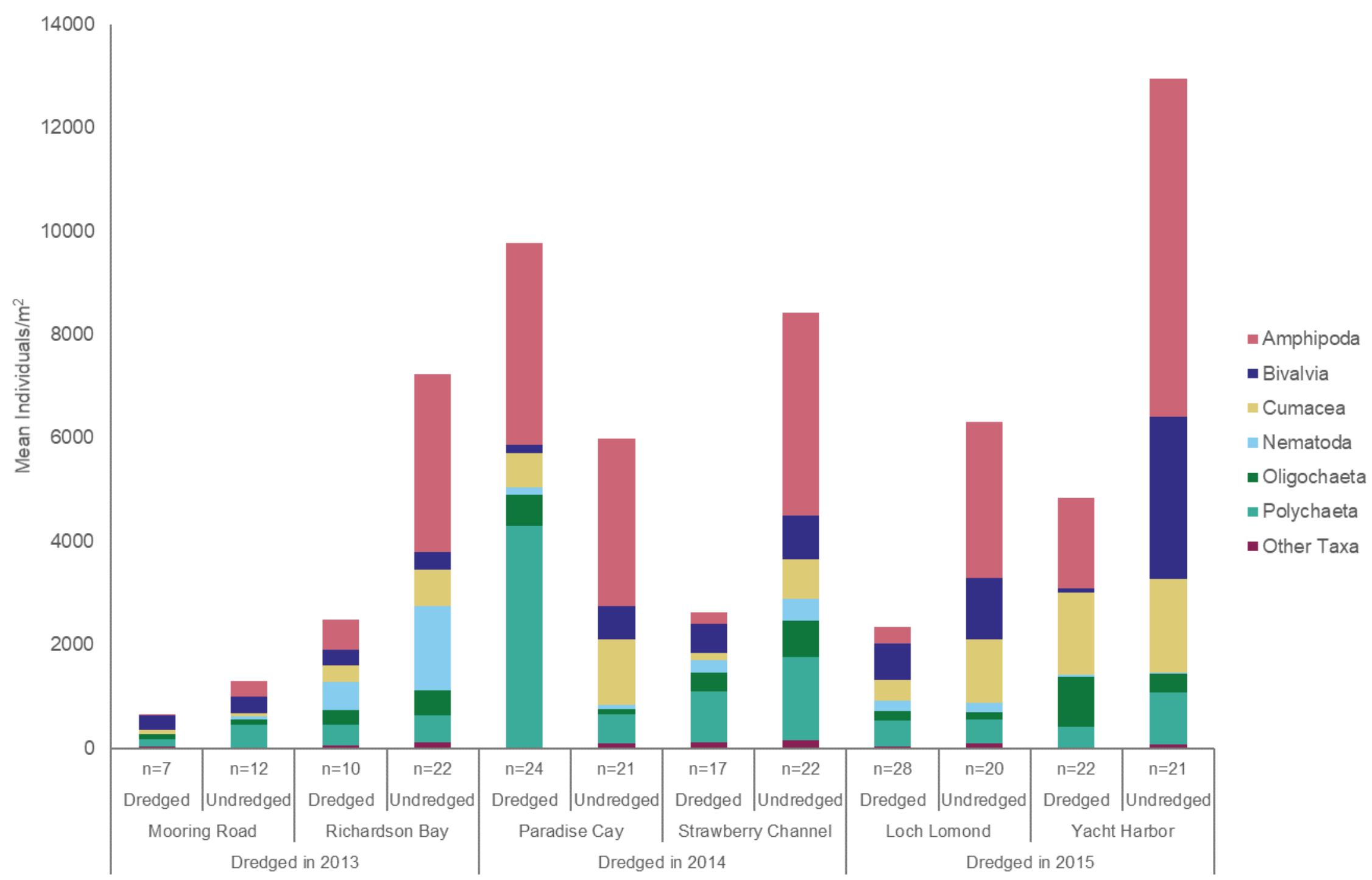

Figure 30. Mean densities (individuals/ meter [ $\left.\mathrm{m}^{2}\right]$ to 10 centimeter [cm] depth) of macroinvertebrate taxa collected in dredged and undredged areas at six study sites (Mooring Road, Richardson Bay, Paradise Cay, Strawberry Channel, Loch Lomond, and Yacht Harbor) in August 2017. 


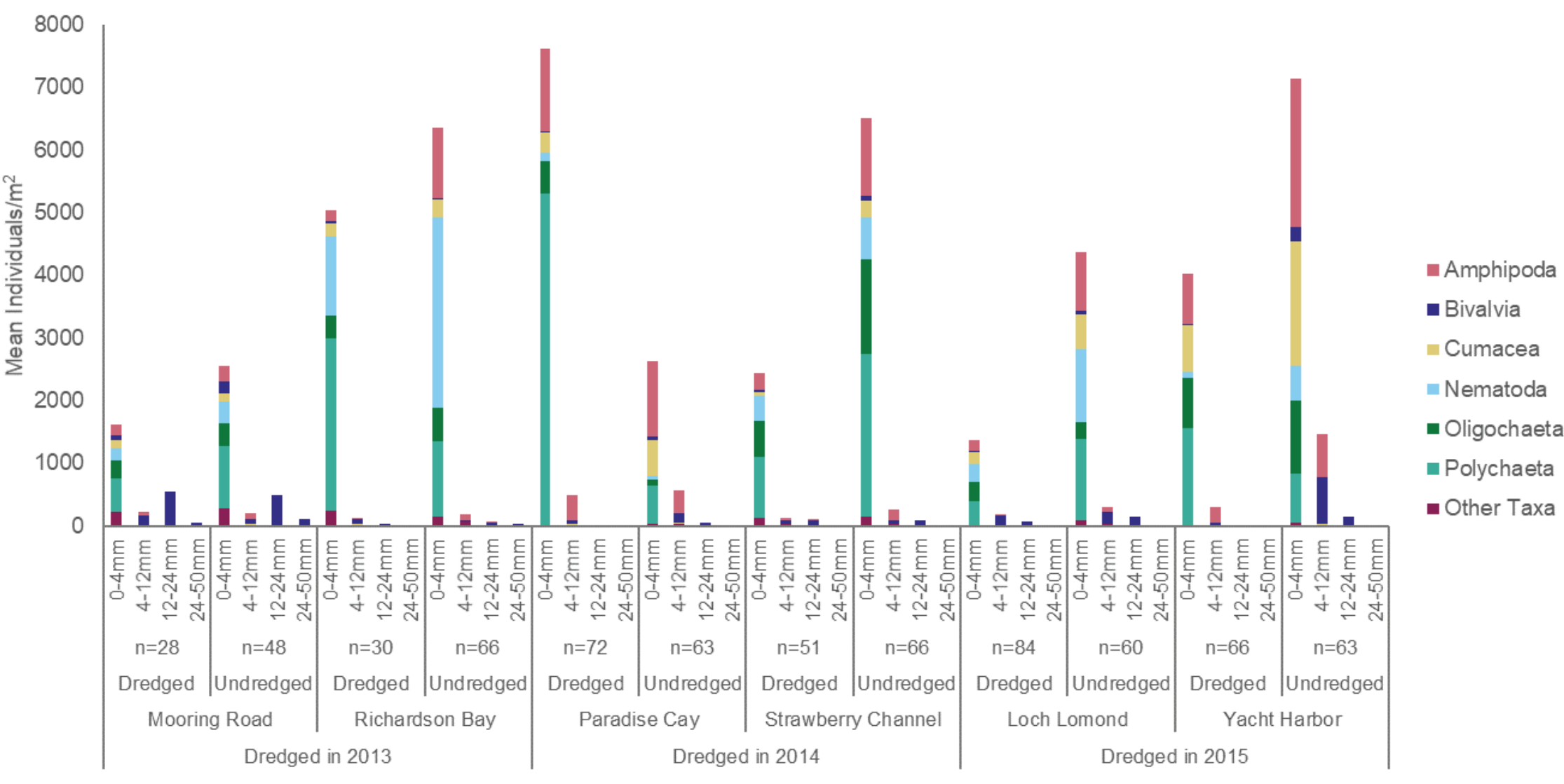

Figure 31. Mean density (individuals/ meter [ $\left.\mathrm{m}^{2}\right]$ ) of macroinvertebrate taxa from different size classes in shallow cores (0-4 centimeter [cm]) from dredged and undredged areas at six study sites (Mooring Road, Richardson Bay, Paradise Cay, Strawberry Channel, Loch Lomond, and Yacht Harbor) in San Francisco Bay. Cores were collected at Mooring Road, Richardson Bay, Paradise Cay, and Strawberry Channel during the pilot and full studies (November 2015, August 2016, January 2017, August 2017) and at Loch Lomond and Yacht Harbor during the full study (August 2016, January 2017, August 2017). 


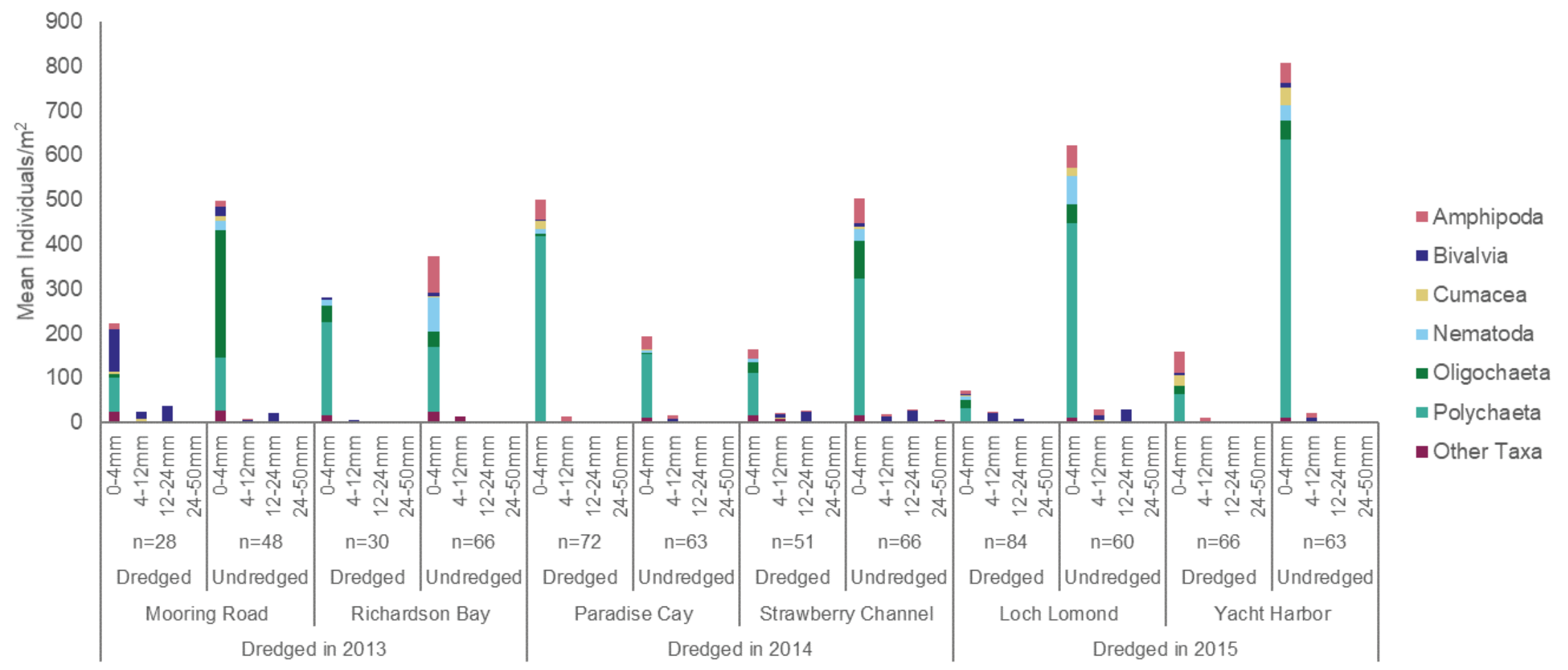

Figure 32. Mean density (individuals/meter [ $\left.\mathrm{m}^{2}\right]$ ) of macroinvertebrate taxa from different size classes in deep cores (4-10 centimeter [cm]) from dredged and undredged areas at six study sites (Mooring Road, Richardson Bay, Paradise Cay, Strawberry Channel, Loch Lomond, and Yacht Harbor) in San Francisco Bay. Cores were collected at Mooring Road, Richardson Bay, Paradise Cay, and Strawberry Channel during the pilot and full studies (November 2015, August 2016, January 2017, August 2017) and at Loch Lomond and Yacht Harbor during the full study (August 2016, January 2017, August 2017). 


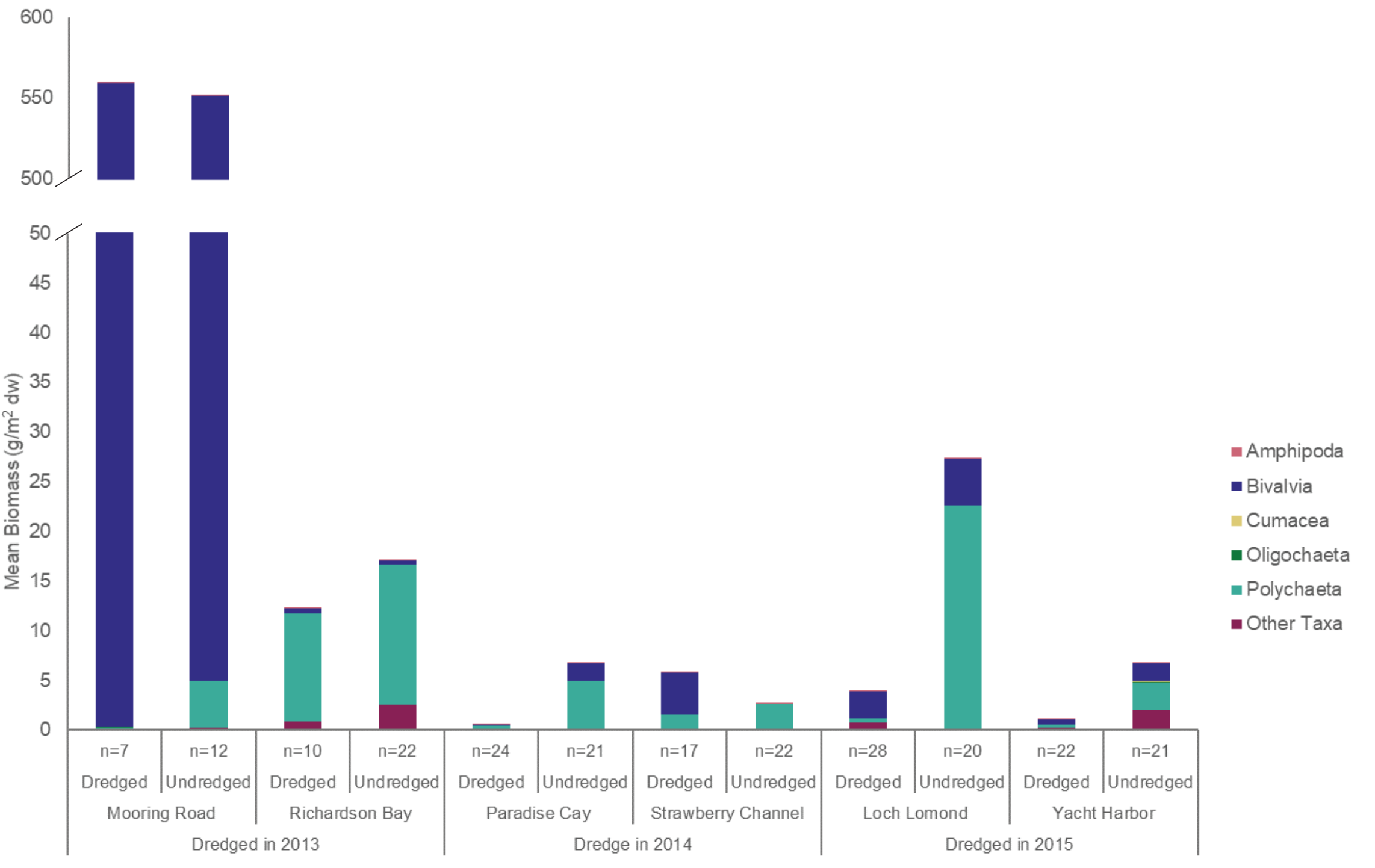

Figure 33. Mean biomass (grams per square meter $\left[\mathrm{g} / \mathrm{m}^{2}\right]$ dry weight $(\mathrm{dw})$ to 10 centimeter [cm] depth) of macroinvertebrate taxa collected in dredged and undredged areas at six study sites (Mooring Road, Richardson Bay, Paradise Cay, Strawberry Channel, Loch Lomond, and Yacht Harbor) in August 2016. 


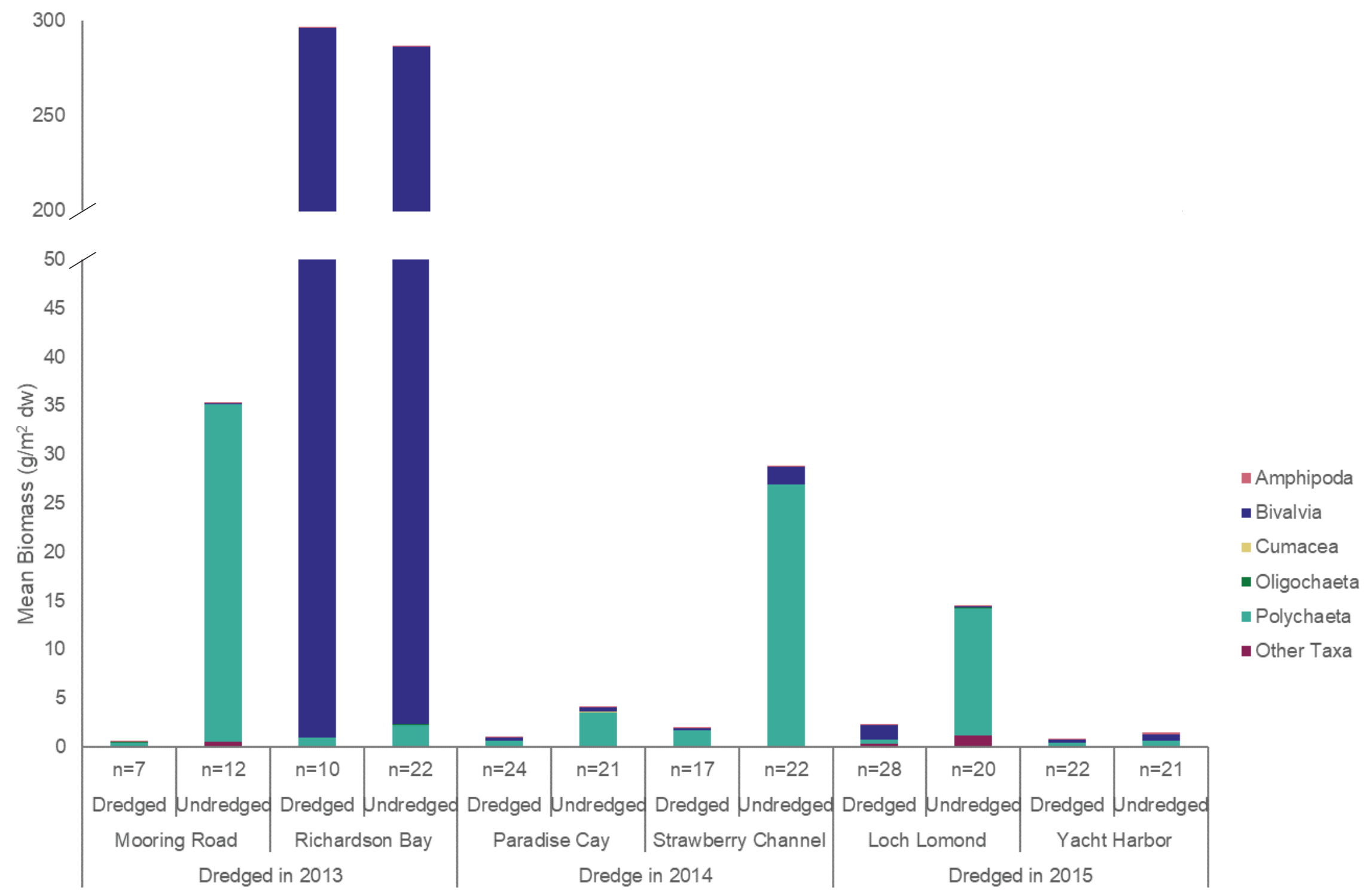

Figure 34. Mean biomass (grams per square meter [ $\left.\mathrm{g} / \mathrm{m}^{2}\right]$ dry weight (dw) to 10 centimeter [cm] depth) of macroinvertebrate taxa collected in dredged and undredged areas at six study sites (Mooring Road, Richardson Bay, Paradise Cay, Strawberry Channel, Loch Lomond, and Yacht Harbor) in January 2017. 


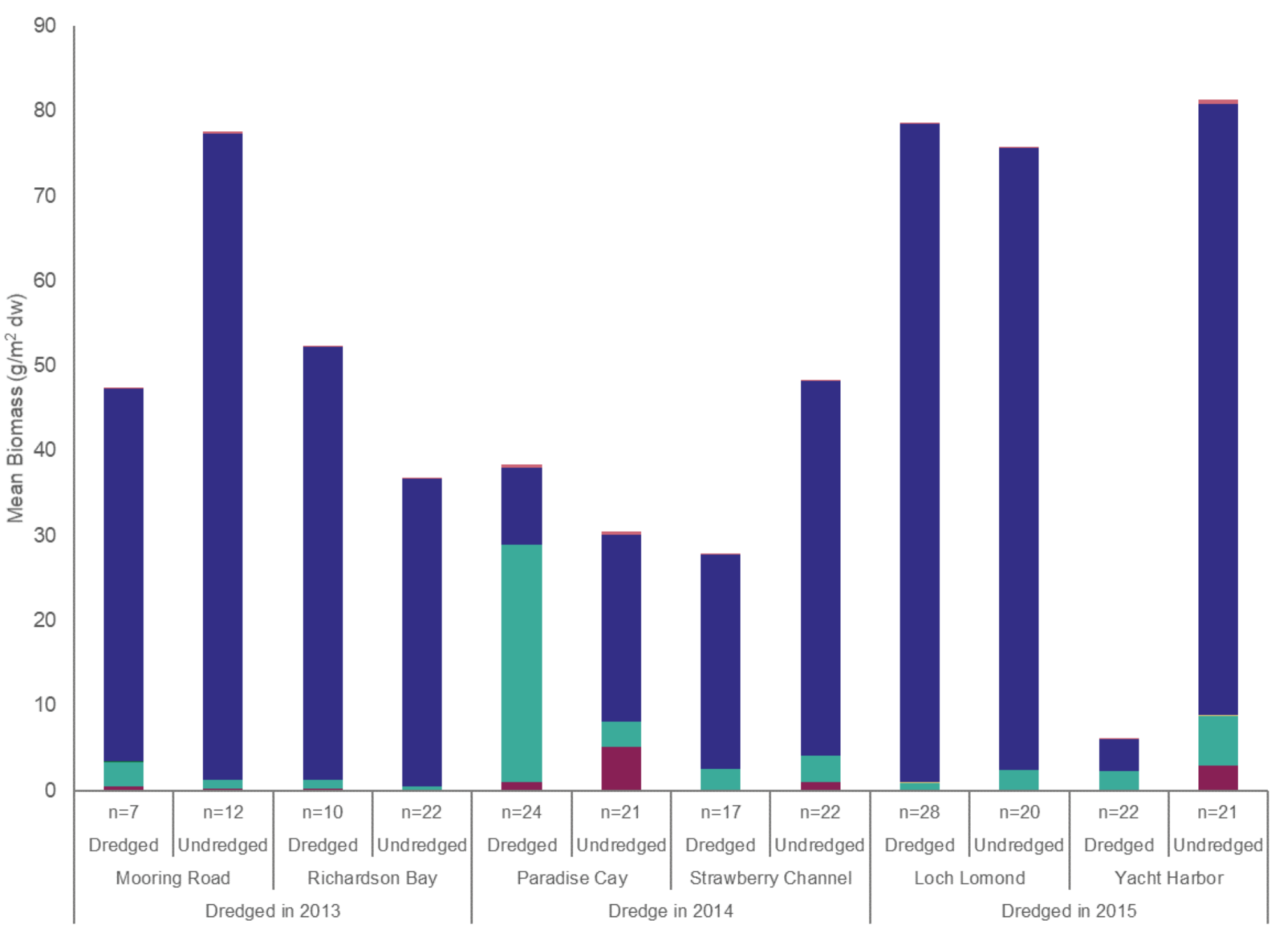

Figure 35. Mean biomass (grams per square meter [ $\left.\mathrm{g} / \mathrm{m}^{2}\right]$ dry weight $(\mathrm{dw})$ to 10 centimeter [cm] depth) of macroinvertebrate taxa collected in dredged and undredged areas at six study sites (Mooring Road, Richardson Bay, Paradise Cay, Strawberry Channel, Loch Lomond, and Yacht Harbor) in August 2017.

- Amphipoda

- Bivalvia

- Cumacea

- Oligochaeta

- Polychaeta

- Other Taxa 


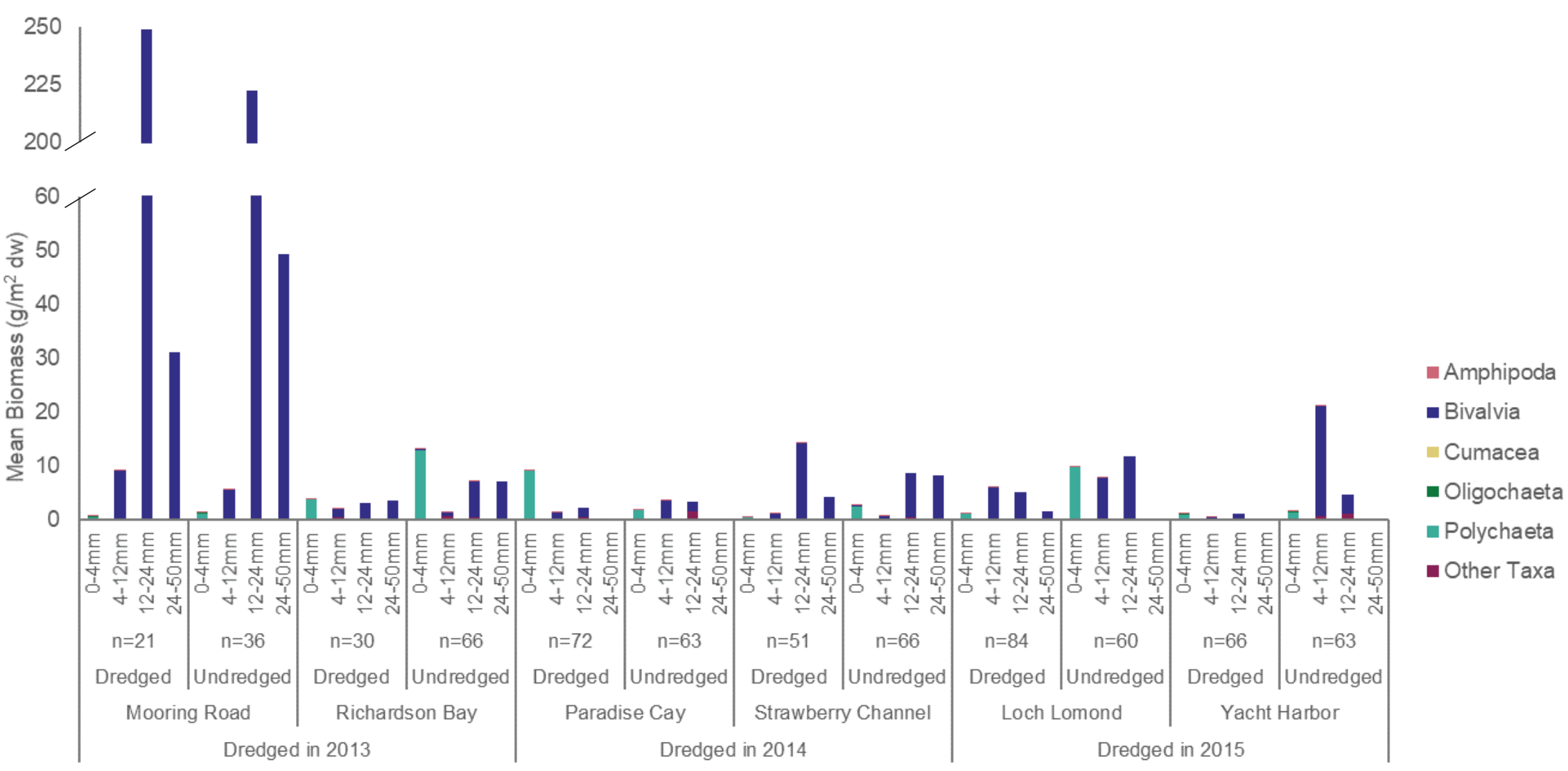

Figure 36. Mean biomass grams per square meter $\left[\mathrm{g} / \mathrm{m}^{2}\right]$ dry weight $(\mathrm{dw})$ of macroinvertebrate taxa from different size classes in shallow cores (0-4 centimeter [cm]) from dredged and undredged areas at six study sites (Mooring Road, Richardson Bay, Paradise Cay, Strawberry Channel, Loch Lomond, and Yacht Harbor) in San Francisco Bay. Cores were collected at all sites during the full study (August 2016, January 2017, August 2017). 


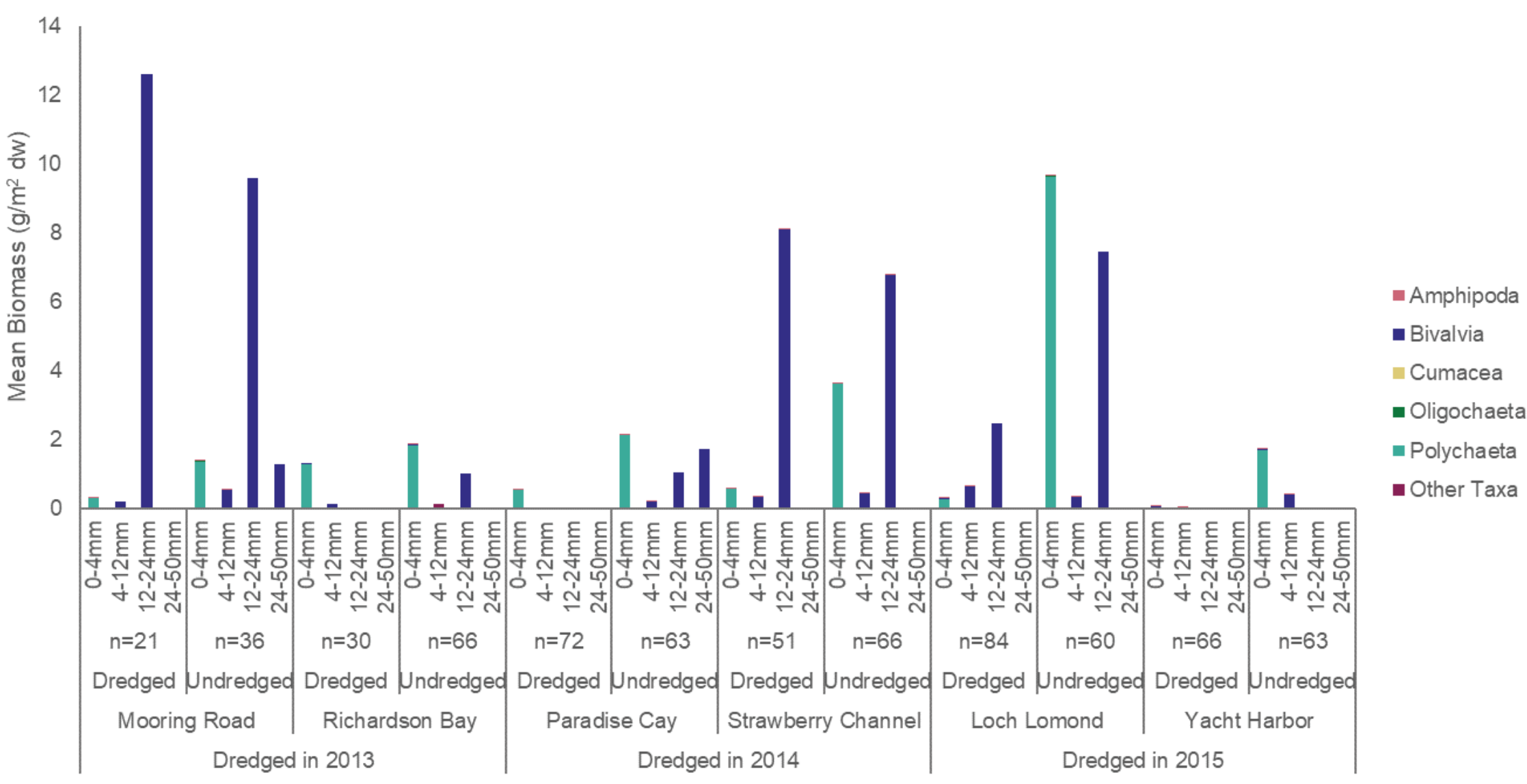

Figure 37. Mean biomass (grams per square meter $\left[\mathrm{g} / \mathrm{m}^{2}\right]$ dry weight $(\mathrm{dw})$ of macroinvertebrate taxa from different size classes in deep cores (4-10 centimeter [cm]) from dredged and undredged areas at six study sites (Mooring Road, Richardson Bay, Paradise Cay, Strawberry Channel, Loch Lomond, and Yacht Harbor) in San Francisco Bay. Cores were collected at all sites during the full study (August 2016, January 2017, August 2017). 
Total energy content of $0-4 \mathrm{~mm}$ and $4-12 \mathrm{~mm}$ macroinvertebrate prey in surface cores $(0-4 \mathrm{~cm})$ and $0-50 \mathrm{~mm}$ prey in whole cores $(0-10 \mathrm{~cm})$ was significantly greater in undredged areas compared to dredged areas (table 12). As with biomass, there were no clear effects of season, salinity, or elevation on energy content; instead, the effects varied depending on the core depth and macroinvertebrate size class (table 12). Overall, energy content of all macroinvertebrate size classes $(0-50 \mathrm{~mm})$ in whole cores $(0-10 \mathrm{~cm})$ varied among sampling periods. In August 2016 and January 2017, energy content was much greater at dredged and undredged locations at Mooring Road (dominated by Bivalvia) compared with all other sites that were dominated by Polychaeta (fig. 38, 39). Energy content was more similar among sites during the August 2017 sampling period, though Paradise Cay dredged area notably had the greatest energy content and was dominated by Polychaeta (fig. 40). In contrast to biomass, much of the available energy content at each site for both surface and deep cores was from Polychaeta, except for Mooring Road which was dominated by energy from Bivalvia near the surface (0-4 cm deep) in the 12-24 mm size class (figs. 41-42).

Overall, potential trophic support for target fishes expressed as average prey biomass available for each species and age class across all sampling sites ranged from $3.04 \mathrm{~g} / \mathrm{m}^{2}$ for juveniles fishes that forage on $0-4 \mathrm{~mm}$ prey in the shallow $(0-4 \mathrm{~cm})$ sediment of dredged areas to $56.97 \mathrm{~g} / \mathrm{m}^{2}$ for larger fishes exploiting prey in all size classes $(0-50 \mathrm{~mm})$ in both shallow and deep $(0-10 \mathrm{~cm})$ sediment in undredged areas (table 2). Total mean available prey biomass in dredged sites range from 35 to 51 percent less than that in undredged sites (table 2). Average energy (secondary productivity) ranged from a low of $50.23 \mathrm{~kJ} / \mathrm{m}^{2}$ for $0-4 \mathrm{~mm}$ prey in shallow, dredged sediments to a high of $310.11 \mathrm{~kJ} / \mathrm{m}^{2}$ for fish that consume all prey size classes at all core depths (table 2). Total mean available energy was 40 to 50 percent less at dredged sites compared to undredged sites (table 2).

Table 12. Summary of general linear mixed model (GLMM) results for total energy of macroinvertebrates from different size classes found in shallow (0-4 centimeters [cm]) and deep $(0-10 \mathrm{~cm}$ ) cores at six sites (Loch Lomond, Mooring Road, Paradise Cay, Richardson Bay, Strawberry Channel, and Yacht Harbor) within dredged and undredged areas.

[Cores were collected during summer and winter 2016-17. Collection site and transects were included in the GLMM as random effects. Orange indicates the relationship between density and the fixed effect was positive, and purple indicates that the relationship was negative. See full GLMM tables 1.12 to 1.16 in appendix for more information. Abbreviations: mm, millimeter; $>$, greater than; $<$, less than]

\begin{tabular}{|c|c|c|c|c|c|}
\hline Core depth & & & $\mathrm{cm}$ & & $0-10 \mathrm{~cm}$ \\
\hline $\begin{array}{c}\text { Macroinvertebrate } \\
\text { size class }\end{array}$ & $\begin{array}{l}0-4 \\
\mathrm{~mm}\end{array}$ & $\begin{array}{c}>4-12 \\
\mathrm{~mm}\end{array}$ & $\begin{array}{c}>12-24 \\
\mathrm{~mm}\end{array}$ & $\begin{array}{c}>24-50 \\
\mathrm{~mm}\end{array}$ & $\begin{array}{c}0-50 \\
\mathrm{~mm}\end{array}$ \\
\hline Fixed effect & $p$ & $p$ & $p$ & $p$ & $p$ \\
\hline Intercept & $<0.001$ & $<0.001$ & $<0.001$ & $<0.001$ & $<0.001$ \\
\hline $\begin{array}{l}\text { Treatment: } \\
\text { undredged }\end{array}$ & $<0.001$ & $<0.001$ & 0 . & 49 & $<0.001$ \\
\hline Season: winter & $<0.001$ & $<0.001$ & 0.952 & $<0.001$ & 0.016 \\
\hline Salinity & $<0.001$ & 0.002 & 0.408 & $<0.001$ & 0.001 \\
\hline Elevation & 0.004 & 0.087 & 0.001 & $<0.001$ & 0.794 \\
\hline
\end{tabular}




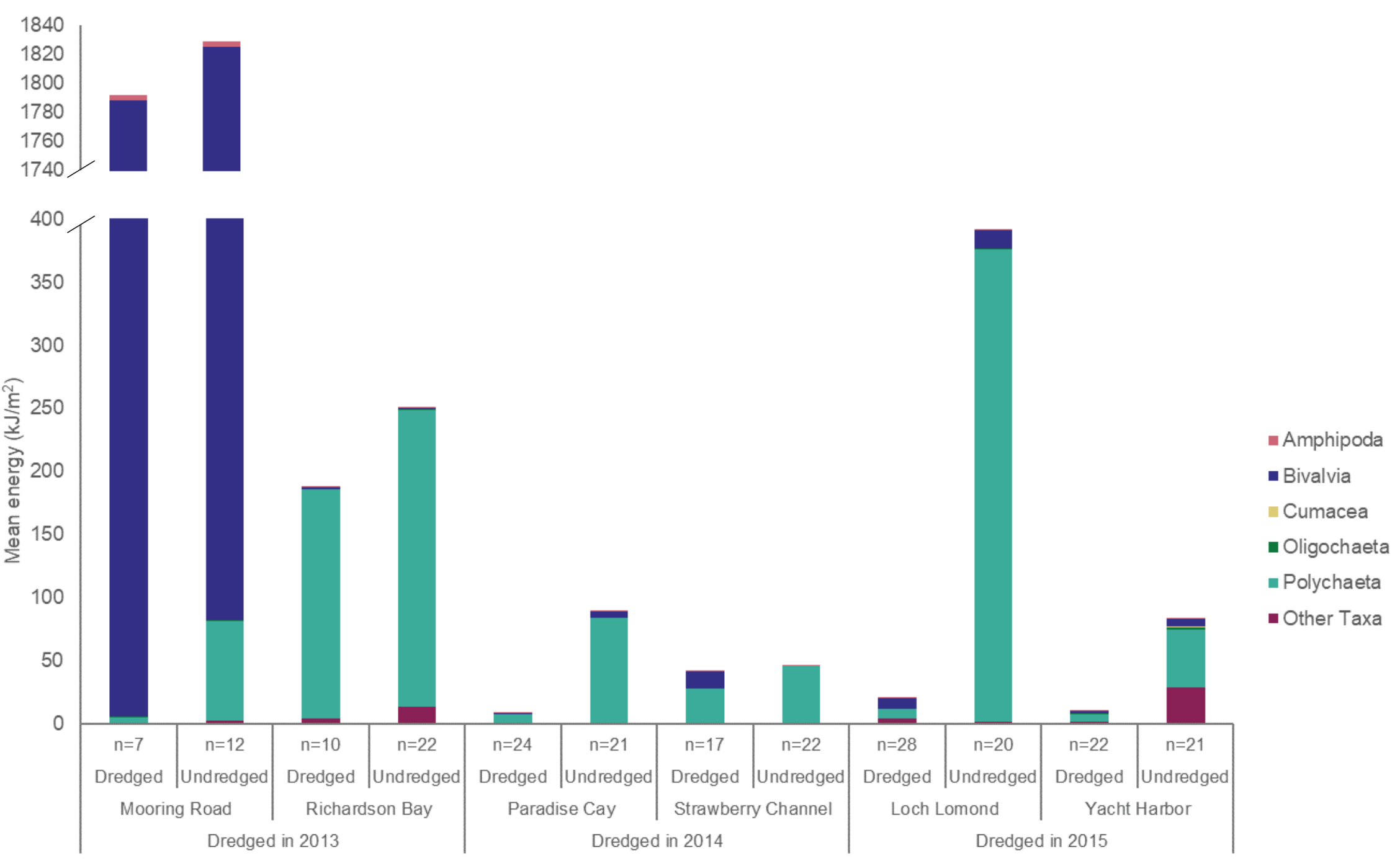

Figure 38. Mean energy (kilojoules per square meter [kJ/m²] to 10 centimeter [cm] depth) of macroinvertebrate taxa collected in dredged and undredged areas at six study sites (Mooring Road, Richardson Bay, Paradise Cay, Strawberry Channel, Loch Lomond, and Yacht Harbor) in August 2016. 


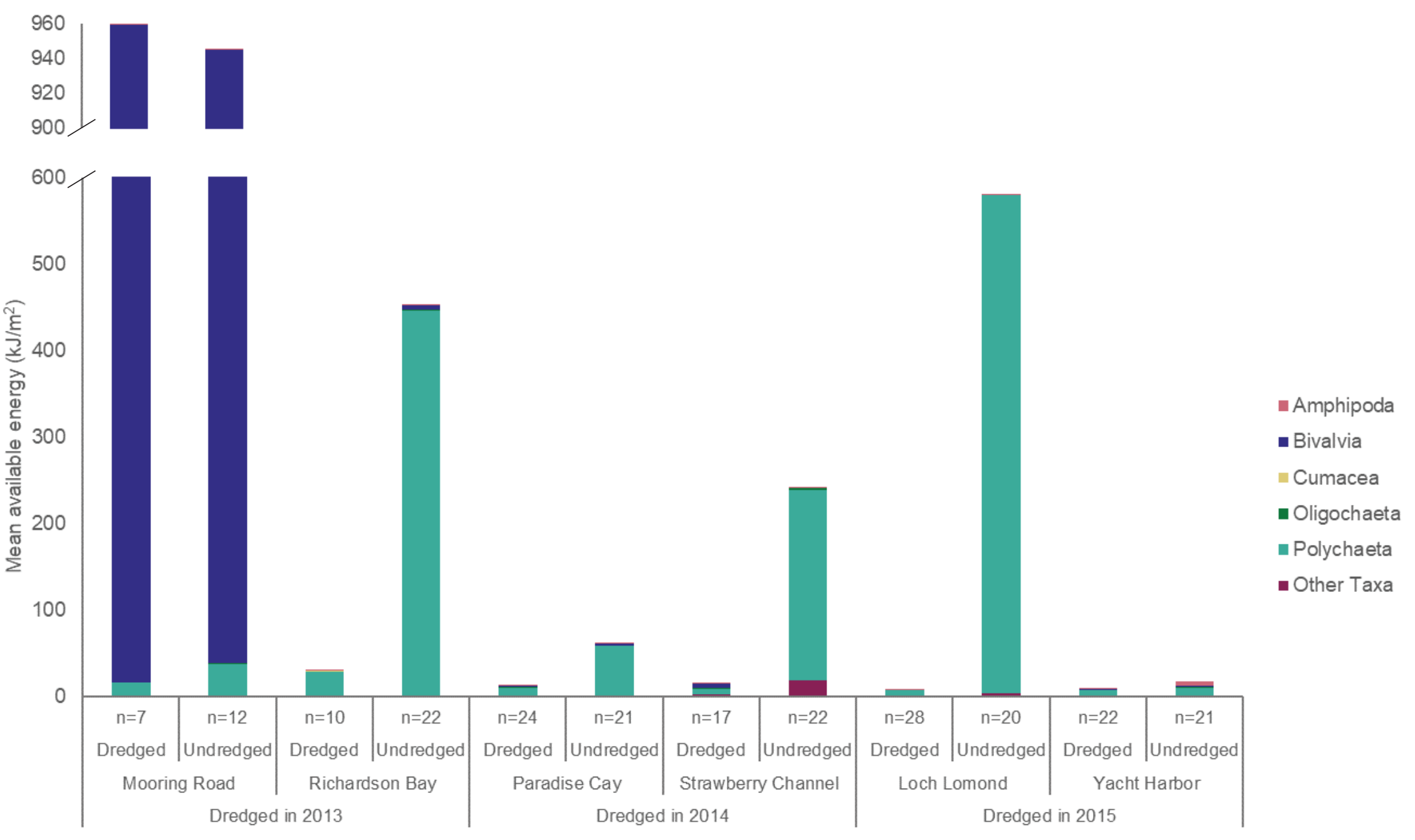

Figure 39. Mean energy (kilojoules per square meter $\left[\mathrm{kJ} / \mathrm{m}^{2}\right]$ to 10 centimeter [cm] depth) of macroinvertebrate taxa collected in dredged and undredged areas at six study sites (Mooring Road, Richardson Bay, Paradise Cay, Strawberry Channel, Loch Lomond, and Yacht Harbor) in January 2017. 


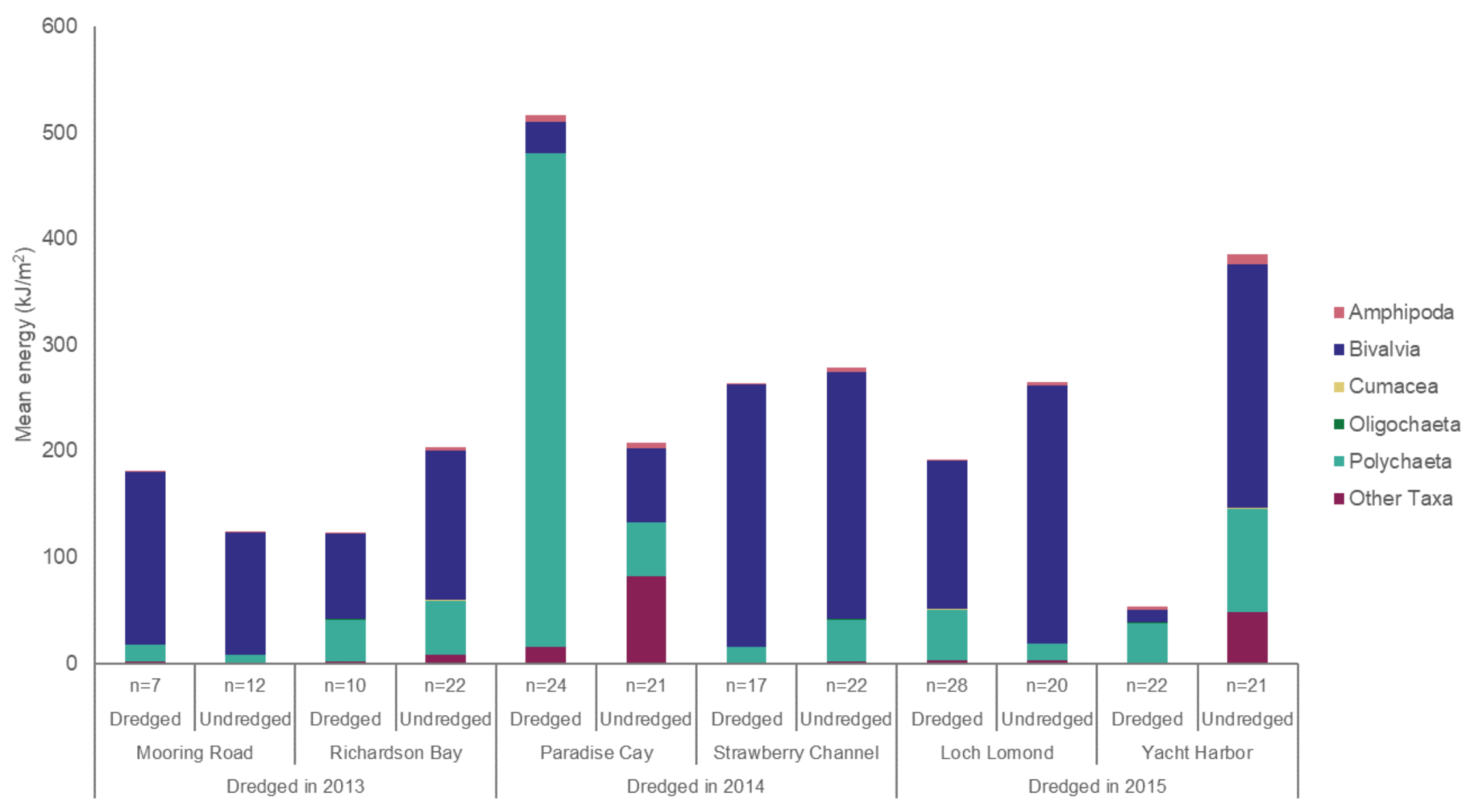

Figure 40. Mean energy (kilojoules per square meter $\left[\mathrm{kJ} / \mathrm{m}^{2}\right]$ to 10 centimeter $[\mathrm{cm}]$ depth) of macroinvertebrate taxa collected in dredged and undredged areas at six study sites (Mooring Road, Richardson Bay, Paradise Cay, Strawberry Channel, Loch Lomond, and Yacht Harbor) in August 2017. 


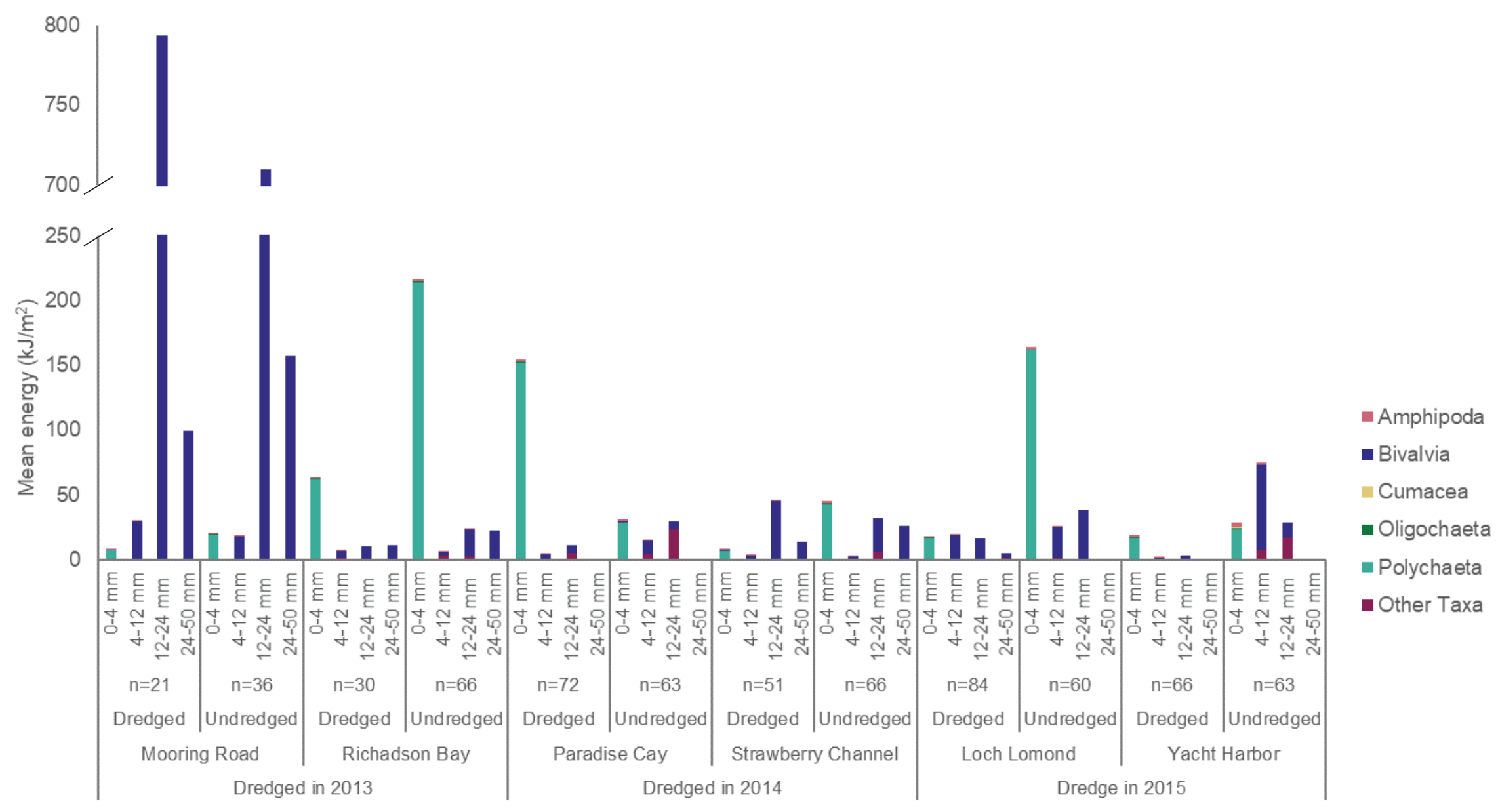

Figure 41. Mean energy (kilojoules per square meter $\left[\mathrm{kJ} / \mathrm{m}^{2}\right]$ ) of macroinvertebrate taxa from different size classes in shallow cores $(0-4$ centimeter [cm]) from dredged and undredged areas at six study sites (Mooring Road, Richardson Bay, Paradise Cay, Strawberry Channel, Loch Lomond, and Yacht Harbor) in San Francisco Bay. Cores were collected at all sites during the full study (August 2016, January 2017, August 2017). 


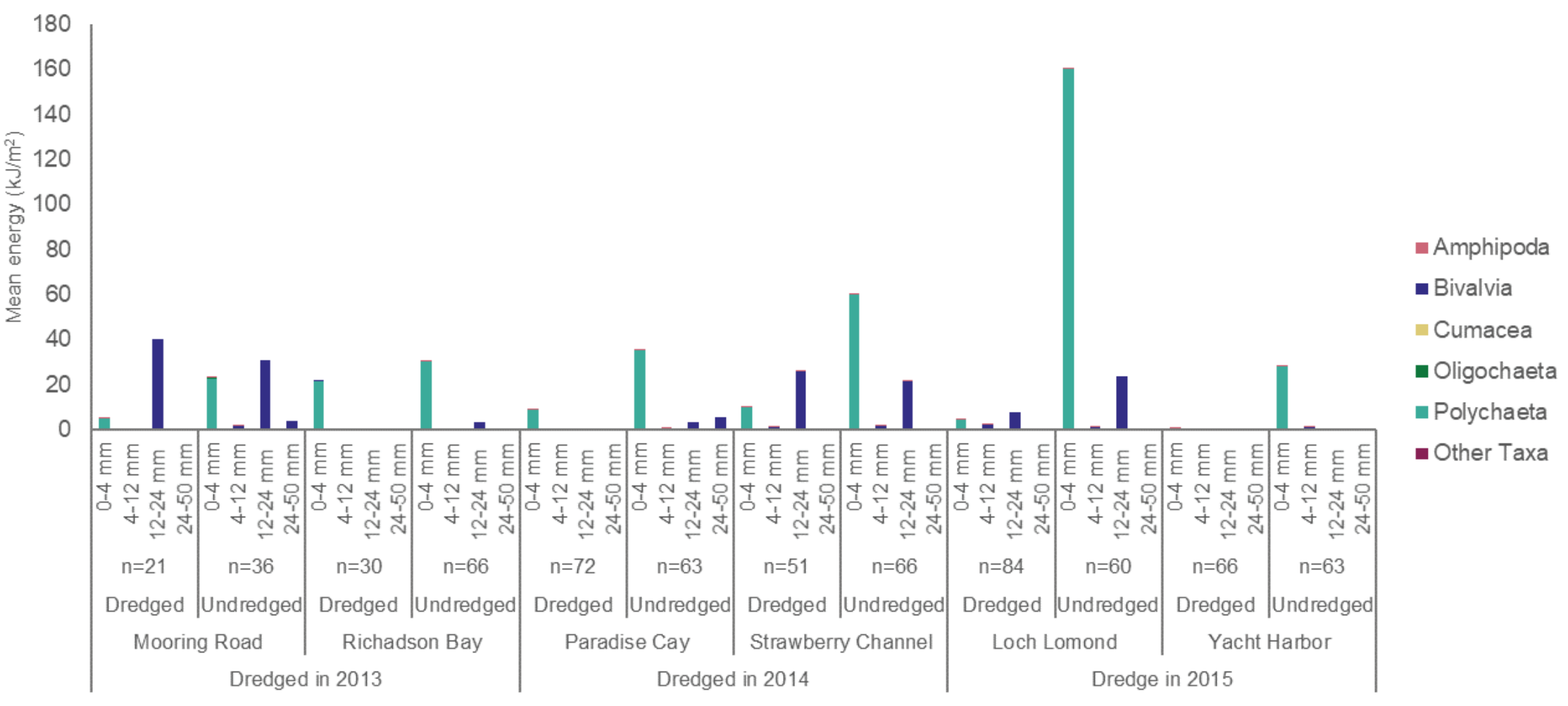

Figure 42. Mean energy (kilojoules per square meter $\left[\mathrm{kJ} / \mathrm{m}^{2}\right]$ ) of macroinvertebrate taxa from different size classes in deep cores (4-10 centimeter [cm]) from dredged and undredged areas at six study sites (Mooring Road, Richardson Bay, Paradise Cay, Strawberry Channel, Loch Lomond, and Yacht Harbor) in San Francisco Bay. Cores were collected at all sites during the full study (August 2016, January 2017, August 2017). 


\section{The Effect of Distance and Time on Macroinvertebrate Density, Biomass and Energy Content}

The effect of distance to nearest dredged area on macroinvertebrate density, biomass, and energy differed among macroinvertebrate size classes and core depths. Density of $0-4 \mathrm{~mm}$ macroinvertebrates at the surface (0-4 cm deep) decreased significantly with increasing distance from dredged area, while densities of all other size classes and core depths, except for $24-50 \mathrm{~mm}$ size-class at the surface were not significantly affected by the distance to nearest dredged area (table 13; fig. 43). Likewise, biomass of $0-4 \mathrm{~mm}$ macroinvertebrates at the surface $(0-4 \mathrm{~cm}$ deep) also decreased significantly as distance to the nearest dredged area increased; however, biomass of 12-24 mm and $24-50 \mathrm{~mm}$ macroinvertebrate size classes at the surface and $0-50 \mathrm{~mm}$ macroinvertebrates in whole cores $(0-10 \mathrm{~cm}$ deep) increased significantly as the distance to the nearest dredged area increased (table 14; fig. 44). Energy content of

Table 13. Summary of general linear mixed model (GLMM) results testing the effects of distance from dredged areas (meters [m]), season, salinity (practical salinity units [psu]), and elevation $(\mathrm{m})$ on total density of macroinvertebrates from different size classes found in shallow $(0-4$ centimeters [ $\mathrm{cm}])$ and deep $(0-10 \mathrm{~cm})$ cores at six sites (Loch Lomond, Mooring Road, Paradise Cay, Richardson Bay, Strawberry Channel, and Yacht Harbor).

[Cores were collected during August 2016, January 2017, and August 2017. Collection site and transects were included in the GLMM as random effects. Orange indicates the relationship between density and the fixed effect was positive, and purple indicates that the relationship was negative. See full GLMM tables 1.17 to 1.21 in appendix for more information. Abbreviations: mm, millimeter; >, greater than; <, less than]

\begin{tabular}{|c|c|c|c|c|c|}
\hline \multirow{2}{*}{$\begin{array}{c}\text { Core depth } \\
\begin{array}{c}\text { Macroinvertebrate } \\
\text { size class }\end{array}\end{array}$} & \multicolumn{4}{|c|}{$0-4 \mathrm{~cm}$} & \multirow{2}{*}{$\begin{array}{l}0-10 \mathrm{~cm} \\
0-50 \mathrm{~mm}\end{array}$} \\
\hline & $\begin{array}{l}\text { o-4 } \\
\mathrm{mm}\end{array}$ & $\begin{array}{c}>4-12 \\
\mathrm{~mm}\end{array}$ & $\begin{array}{c}>12-24 \\
\mathrm{~mm}\end{array}$ & $\begin{array}{c}>24-50 \\
\mathrm{~mm}\end{array}$ & \\
\hline Fixed effect & $p$ & $p$ & $p$ & $p$ & $p$ \\
\hline Intercept & $<0.001$ & $<0.001$ & $<0.001$ & $\mathrm{X}^{1}$ & $<0.001$ \\
\hline $\begin{array}{l}\text { Distance from } \\
\text { dredged }(\mathrm{m})\end{array}$ & 0.043 & $<0.001$ & $<0.001$ & & 0.423 \\
\hline Season: winter & $<0.001$ & $<0.001$ & 0.006 & & 0.018 \\
\hline Salinity & $<0.001$ & $<0.001$ & 0.133 & & 0.013 \\
\hline Elevation & $<0.001$ & $<0.001$ & 0.235 & & $<0.001$ \\
\hline
\end{tabular}

${ }^{1}$ Model did not converge owing to limited data.
0-4 mm surface ( $0-4 \mathrm{~cm}$ deep) macroinvertebrates followed the same patterns as density and biomass, decreasing significantly as distance to the nearest dredged area increased. Similar to biomass, energy content of $12-24 \mathrm{~mm}$ and 24-50 $\mathrm{mm}$ macroinvertebrates at the surface and $0-50 \mathrm{~mm}$ macroinvertebrates in whole cores $(0-10 \mathrm{~cm}$ deep) increased significantly as the distance to the nearest dredged area increased (table 15; fig. 45).

We found a positive effect of time-since-dredging on macroinvertebrate density, biomass, and energy content. All three parameters increased significantly for all size classes and core depths as time-since-dredging increased, except for the density of $0-4 \mathrm{~mm}$ macroinvertebrates at the surface which was not significantly affected by time-since-dredging (tables 16-18; figs. 46-48). In addition, density, biomass, and energy models for 24-50 $\mathrm{mm}$ macroinvertebrates in surface cores did not converge, so an effect of time could not be evaluated for this class of macroinvertebrates. Season (winter) and salinity had a negative relationship with biomass and energy content for all size classes and core depths (tables 17-18).

Table 14. Summary of general linear mixed model (GLMM) results testing the effects of distance to nearest dredged areas (meters [m]), season, salinity (practical salinity units [psu]), and elevation $(\mathrm{m})$ on total biomass of macroinvertebrates from different size classes found in shallow $(0-4$ centimeters $[\mathrm{cm}])$ and deep $(0-10 \mathrm{~cm})$ cores at six sites (Loch Lomond, Mooring Road, Paradise Cay, Richardson Bay, Strawberry Channel, and Yacht Harbor).

[Cores were collected during summer and winter 2016-17. Collection site and transects were included in the GLMM as random effects. Orange indicates the relationship between density and the fixed effect was positive, and purple indicates that the relationship was negative. See full GLMM tables 1.22 to 1.26 in appendix for more information. Abbreviations: mm, millimeter; $>$, greater than; $<$, less than]

\begin{tabular}{|c|c|c|c|c|c|}
\hline Core depth & & $0-4$ & cm & & $0-10 \mathrm{~cm}$ \\
\hline $\begin{array}{l}\text { Macroinvertebrate } \\
\text { size class }\end{array}$ & 0-4 mm & $\begin{array}{c}>4-12 \\
\mathrm{~mm}\end{array}$ & $\begin{array}{c}>12-24 \\
\mathrm{~mm}\end{array}$ & $\begin{array}{c}>24-50 \\
\mathrm{~mm}\end{array}$ & 0-50 mm \\
\hline Fixed effect & $P$ & $p$ & $\boldsymbol{p}$ & $\boldsymbol{p}$ & $p$ \\
\hline Intercept & 0.004 & $<0.001$ & $<0.001$ & $<0.001$ & $<0.001$ \\
\hline $\begin{array}{l}\text { Distance from } \\
\text { dredged }(\mathrm{m})\end{array}$ & 038 & 0.134 & 0.419 & 0.605 & $<0.001$ \\
\hline Season: winter & $<0.001$ & $<0.00$ & 0.005 & $<0.001$ & $<0.001$ \\
\hline Salinity & $<0.001$ & $<0.001$ & 0.110 & $<0.001$ & 0.053 \\
\hline Elevation & 0.355 & 0.147 & $<0.001$ & $<0.001$ & $<0.001$ \\
\hline
\end{tabular}




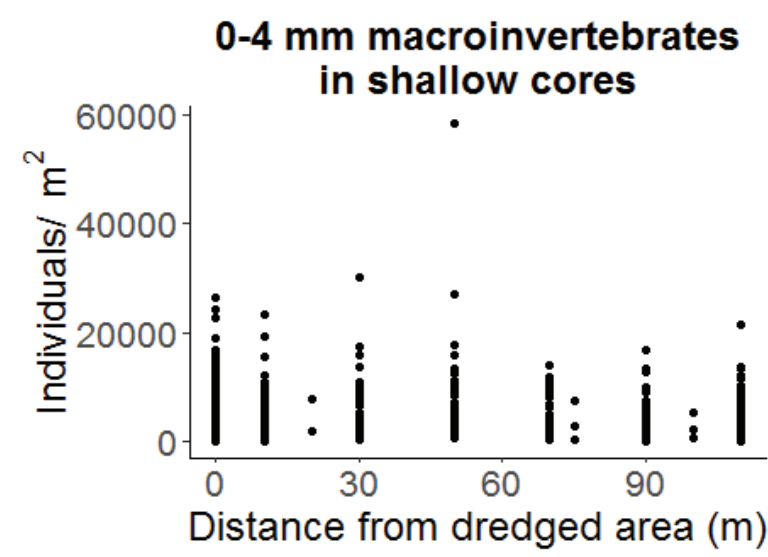

>12-24 mm macroinvertebrates

in shallow cores

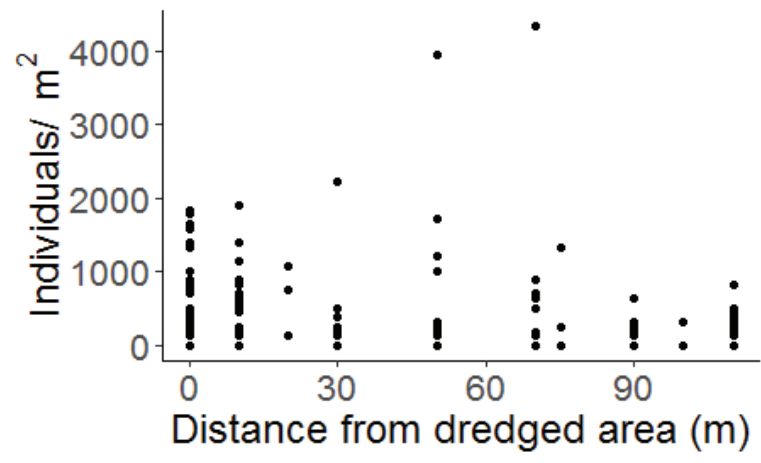

>4-12 mm macroinvertebrates in shallow cores

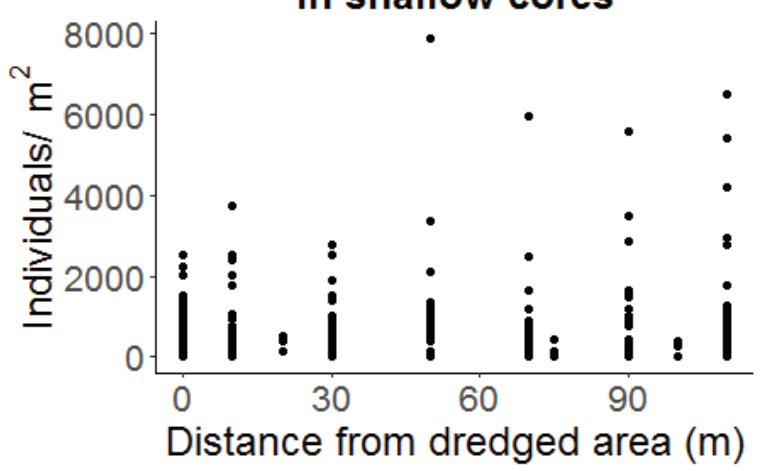

>24-50 mm macroinvertebrates

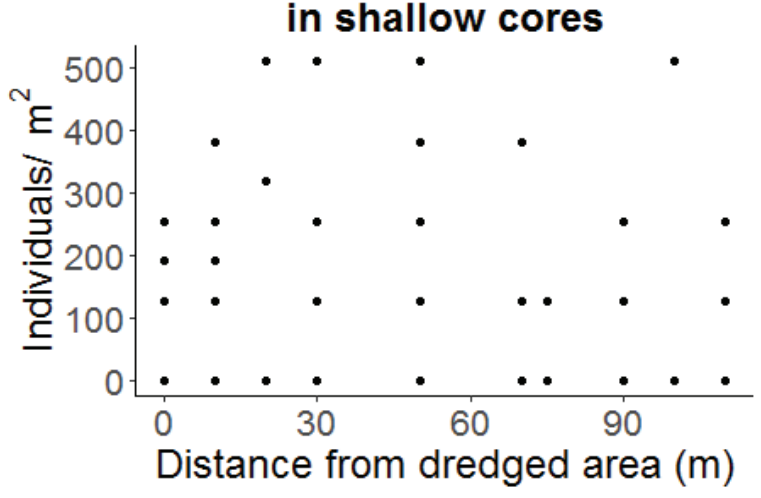

0-50 mm macroinvertebrates in whole cores

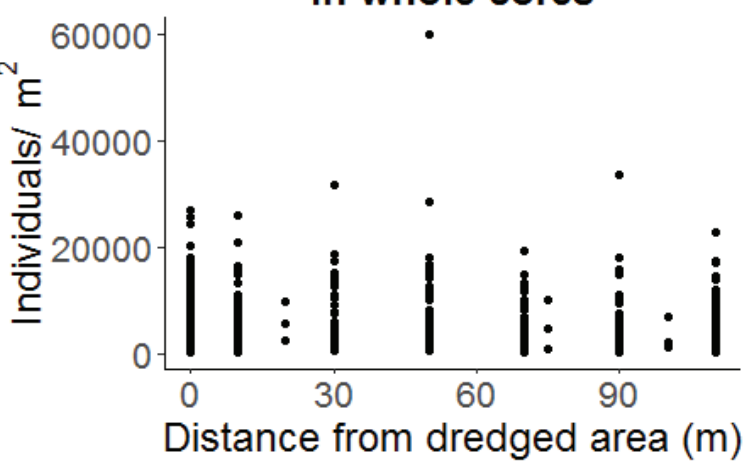

Figure 43. Change in macroinvertebrate density (individuals/square meter [m²]) by size class in shallow (0-4 centimeter [cm]) and whole (0-10 $\mathrm{cm}) \mathrm{core}$ fractions with increasing distance (meter [m]) from a dredged area. Cores were collected at six study sites (Loch Lomond, Mooring Road, Paradise Cay, Richardson Bay, Strawberry Channel, and Yacht Harbor) in San Francisco Bay. 


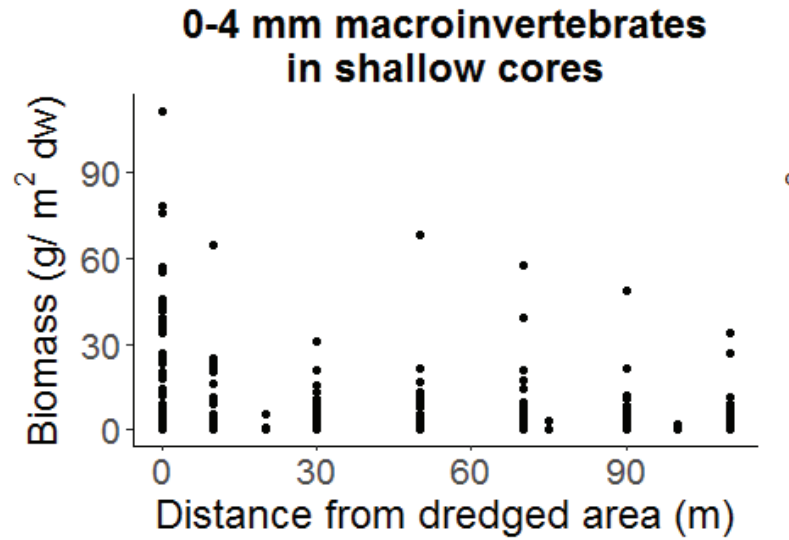

$>12-24 \mathrm{~mm}$ macroinvertebrates

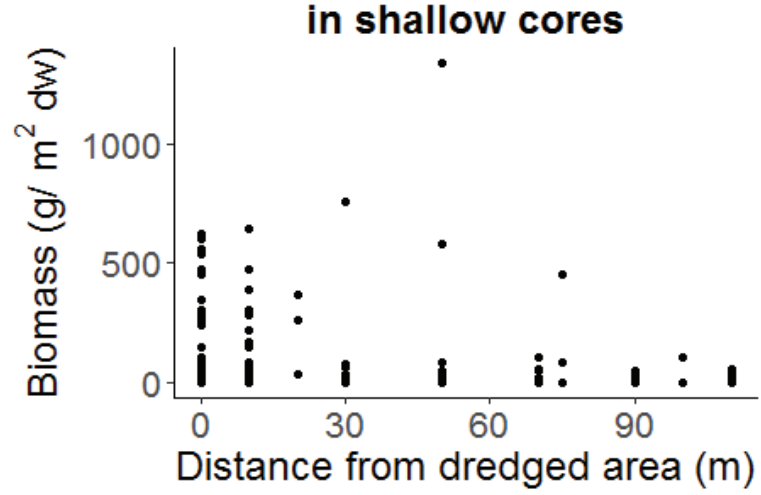

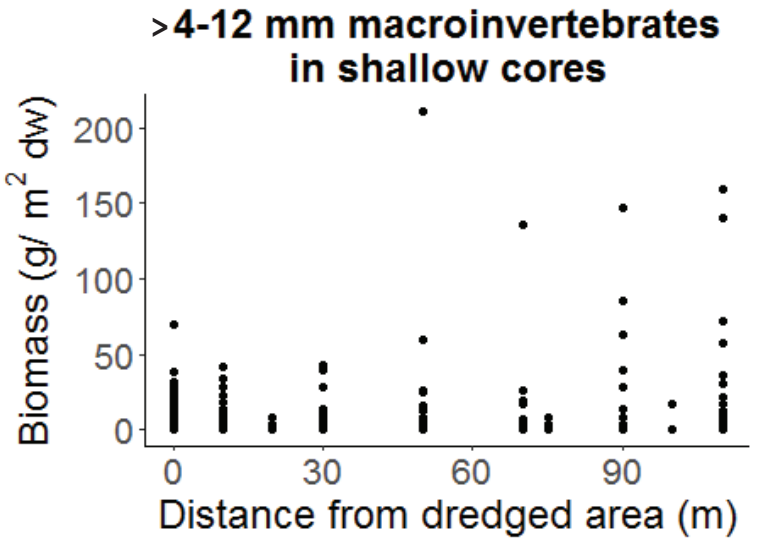

>24-50 mm macroinvertebrates in shallow cores

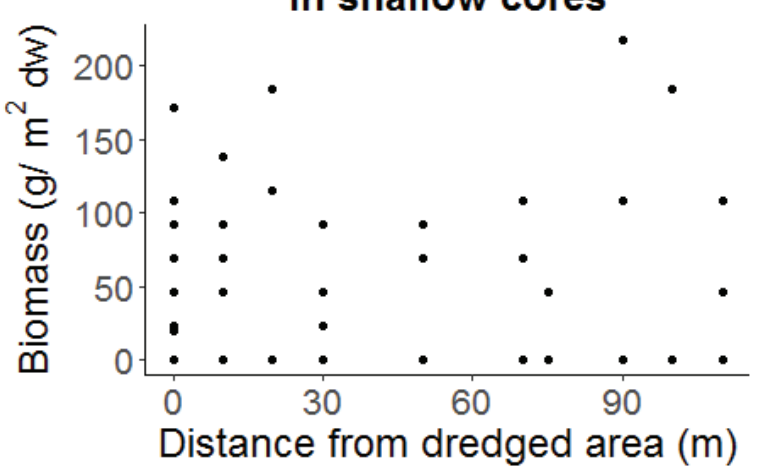

Figure 44. Change in macroinvertebrate biomass (grams per square meter dry weight $\left.\left[\mathrm{g} / \mathrm{m}^{2} \mathrm{dw}\right]\right)$ by size class in shallow $(0-4$ centimeters [cm]) and whole $(0-10 \mathrm{~cm}) \mathrm{core}$ fractions with increasing distance (meters [m]) from a dredged area. Cores were collected at six study sites (Loch Lomond, Mooring Road, Paradise Cay, Richardson Bay,

Strawberry Channel, and Yacht Harbor) in San Francisco Bay. 
Table 15. Summary of general linear mixed model (GLMM) results testing the effects of distance from dredged areas (meters [m]), season, salinity (practical salinity units [psu]), and elevation $(\mathrm{m})$ on total energy of macroinvertebrates from different size classes found in shallow (0-4 centimeters [cm]) and deep $(0-10 \mathrm{~cm}$ ) cores at six sites (Loch Lomond, Mooring Road, Paradise Cay, Richardson Bay, Strawberry Channel, and Yacht Harbor).

[Cores were collected during summer and winter 2016-17. Collection site and transects were included in the GLMM as random effects. Orange indicates the relationship between density and the fixed effect was positive, and purple indicates that the relationship was negative. See full GLMM tables 1.27 to 1.31 in appendix for more information. Abbreviations: mm, millimeter; $>$, greater than; $<$, less than]

\begin{tabular}{|c|c|c|c|c|c|}
\hline \multirow{2}{*}{$\begin{array}{c}\text { Core depth } \\
\begin{array}{c}\text { Macroinvertebrate } \\
\text { size class }\end{array}\end{array}$} & \multicolumn{4}{|c|}{$0-4 \mathrm{~cm}$} & \multirow{2}{*}{$\begin{array}{c}0-10 \mathrm{~cm} \\
0-50 \\
\mathrm{~mm}\end{array}$} \\
\hline & $\begin{array}{l}0-4 \\
\mathrm{~mm}\end{array}$ & $\begin{array}{c}>4-12 \\
\mathrm{~mm}\end{array}$ & $\begin{array}{c}>12-24 \\
\mathrm{~mm}\end{array}$ & $\begin{array}{c}>24-50 \\
\mathrm{~mm}\end{array}$ & \\
\hline Fixed effect & $p$ & $p$ & $p$ & $p$ & $p$ \\
\hline Intercept & $<0.001$ & $<0.001$ & $<0.001$ & $<0.001$ & $<0.001$ \\
\hline $\begin{array}{l}\text { Distance from } \\
\text { dredged (m) }\end{array}$ & 0.032 & 0.061 & 0.277 & 0.570 & $<0.001$ \\
\hline Season: winter & $<0.001$ & $<0.001$ & 0.946 & $<0.001$ & 0.136 \\
\hline Salinity & $<0.001$ & 0.003 & 0.415 & $<0.001$ & $<0.001$ \\
\hline Elevation & 0.286 & 0.022 & $<0.001$ & $<0.001$ & 0.009 \\
\hline
\end{tabular}

Table 17. Summary of general linear mixed model (GLMM) results testing the effects of time since dredged (years), season, salinity (practical salinity unit [psu]), and elevation (meter [m]) on total biomass of macroinvertebrates from different size classes found in shallow (0-4 centimeters [cm]) and deep (0-10 cm) cores at six sites (Loch Lomond, Mooring Road, Paradise Cay, Richardson Bay, Strawberry Channel, and Yacht Harbor).

[Cores were collected during summer and winter 2016-17. Collection site and transects were included in the GLMM as random effects. Orange indicates the relationship between density and the fixed effect was positive, and purple indicates that the relationship was negative. See full GLMM tables 1.37 to 1.40 in appendix for more information. Abbreviations: mm, millimeter; $>$, greater than; $<$, less than]

\begin{tabular}{|c|c|c|c|c|c|}
\hline \multirow{2}{*}{$\begin{array}{c}\text { Core depth } \\
\text { Macroinvertebrate } \\
\text { size class }\end{array}$} & \multicolumn{4}{|c|}{$0-4 \mathrm{~cm}$} & \multirow{2}{*}{$\frac{0-10 \mathrm{~cm}}{0-50 \mathrm{~mm}}$} \\
\hline & 0-4 mm & $\begin{array}{c}>4-12 \\
\mathrm{~mm}\end{array}$ & $\begin{array}{c}>12-24 \\
\mathrm{~mm}\end{array}$ & $\begin{array}{c}>24-50 \\
\mathrm{~mm}\end{array}$ & \\
\hline Fixed effect & $p$ & $p$ & $p$ & $P$ & $p$ \\
\hline Intercept & 0.177 & $<0.001$ & $<0.001$ & $\mathrm{X}^{1}$ & $<0.001$ \\
\hline $\begin{array}{l}\text { Time since dredged } \\
\quad \text { (years) }\end{array}$ & $<0.001$ & $<0.001$ & 0.025 & & $<0.001$ \\
\hline Season: winter & $<0.001$ & $<0.001$ & $<0.001$ & & $=0.001$ \\
\hline Salinity & 0.032 & $<0.001$ & $<0.001$ & & $<0.001$ \\
\hline Elevation & 0.003 & 0.059 & 0.167 & & 0.414 \\
\hline
\end{tabular}

${ }^{1}$ Model did not converge owing to limited data.
Table 16. Summary of general linear mixed model (GLMM) results testing the effects of time-since-dredged (years), season, salinity (practical salinity units [psu]), and elevation (meters [m]) on total density of macroinvertebrates from different size classes found in shallow (0-4 centimeter [cm]) and deep $(0-10 \mathrm{~cm})$ cores at six sites (Loch Lomond, Mooring Road, Paradise Cay, Richardson Bay, Strawberry Channel, and Yacht Harbor).

[Cores were collected during August 2016, January 2017, and August 2017. Collection site and transects were included in the GLMM as random effects. Orange indicates the relationship between density and the fixed effect was positive, and purple indicates that the relationship was negative. See full GLMM tables 1.32 to 1.36 in appendix for more information. Abbreviations: mm, millimeter; >, greater than; <, less than]

\begin{tabular}{|c|c|c|c|c|c|}
\hline Core depth & & & cm & & $0-10 \mathrm{~cm}$ \\
\hline $\begin{array}{l}\text { Macroinvertebrate } \\
\text { size class }\end{array}$ & $\begin{array}{l}0-4 \\
\mathrm{~mm}\end{array}$ & $\begin{array}{c}>4-12 \\
\mathrm{~mm}\end{array}$ & $\begin{array}{c}>12-24 \\
\mathrm{~mm}\end{array}$ & $\begin{array}{c}>24-50 \\
\mathrm{~mm}\end{array}$ & $\begin{array}{l}0-50 \\
\mathrm{~mm}\end{array}$ \\
\hline Fixed effect & $p$ & $p$ & $p$ & $p$ & $p$ \\
\hline Intercept & $<0.001$ & $<0.001$ & 0.262 & $\mathrm{X}^{1}$ & $<0.001$ \\
\hline $\begin{array}{l}\text { Time since dredged } \\
\text { (years) }\end{array}$ & 0.144 & 0.025 & 0.015 & & 0.001 \\
\hline Season: winter & 0.032 & $<0.001$ & 0.035 & & 0.403 \\
\hline Salinity & 0.092 & $<0.001$ & 0.868 & & 0.551 \\
\hline Elevation & 0.141 & 0.005 & 0.220 & & 0.174 \\
\hline
\end{tabular}

${ }_{1}$ Model did not converge owing to limited data.

Table 18. Summary of general linear mixed model (GLMM) results testing the effects of time since dredged (years), season, salinity (practical salinity units [psu]), and elevation (meters [m]) on total energy of macroinvertebrates from different size classes found in shallow $(0-4$ centimeters $[\mathrm{cm}])$ and deep $(0-10 \mathrm{~cm})$ cores at six sites (Loch Lomond, Mooring Road, Paradise Cay, Richardson Bay, Strawberry Channel, and Yacht Harbor).

[Cores were collected during summer and winter 2016-17. Collection site and transects were included in the GLMM as random effects. Orange indicates the relationship between density and the fixed effect was positive, and purple indicates that the relationship was negative. See full GLMM tables 1.41 to 1.44 in appendix for more information. Abbreviations: mm, millimeter; >, greater than; $<$, less than]

\begin{tabular}{|c|c|c|c|c|c|}
\hline Core depth & & $0-4$ & $\mathrm{~cm}$ & & $0-10 \mathrm{~cm}$ \\
\hline $\begin{array}{l}\text { Macroinvertebrate } \\
\text { size class }\end{array}$ & $\begin{array}{l}0-4 \\
\mathrm{~mm}\end{array}$ & $\begin{array}{c}>4-12 \\
\mathrm{~mm}\end{array}$ & $\begin{array}{c}>12-24 \\
\mathrm{~mm}\end{array}$ & $\begin{array}{c}>24-50 \\
\mathrm{~mm}\end{array}$ & $\begin{array}{l}\text { 0-50 } \\
\mathrm{mm}\end{array}$ \\
\hline Fixed effect & p & p & p & p & p \\
\hline Intercept & $<0.001$ & $<0.001$ & $<0.001$ & $\mathrm{X}^{1}$ & $<0.001$ \\
\hline $\begin{array}{l}\text { Time since dredged } \\
\text { (years) }\end{array}$ & $<0.001$ & $<0.001$ & 0.003 & & $<0.001$ \\
\hline Season: winter & $=0.001$ & $<0.001$ & $<0.001$ & & $=0.001$ \\
\hline Salinity & 0.019 & $<0.001$ & $<0.001$ & & $<0.001$ \\
\hline Elevation & 0.006 & 0.003 & 0.129 & & 0.013 \\
\hline
\end{tabular}

1Model did not converge owing to limited data. 

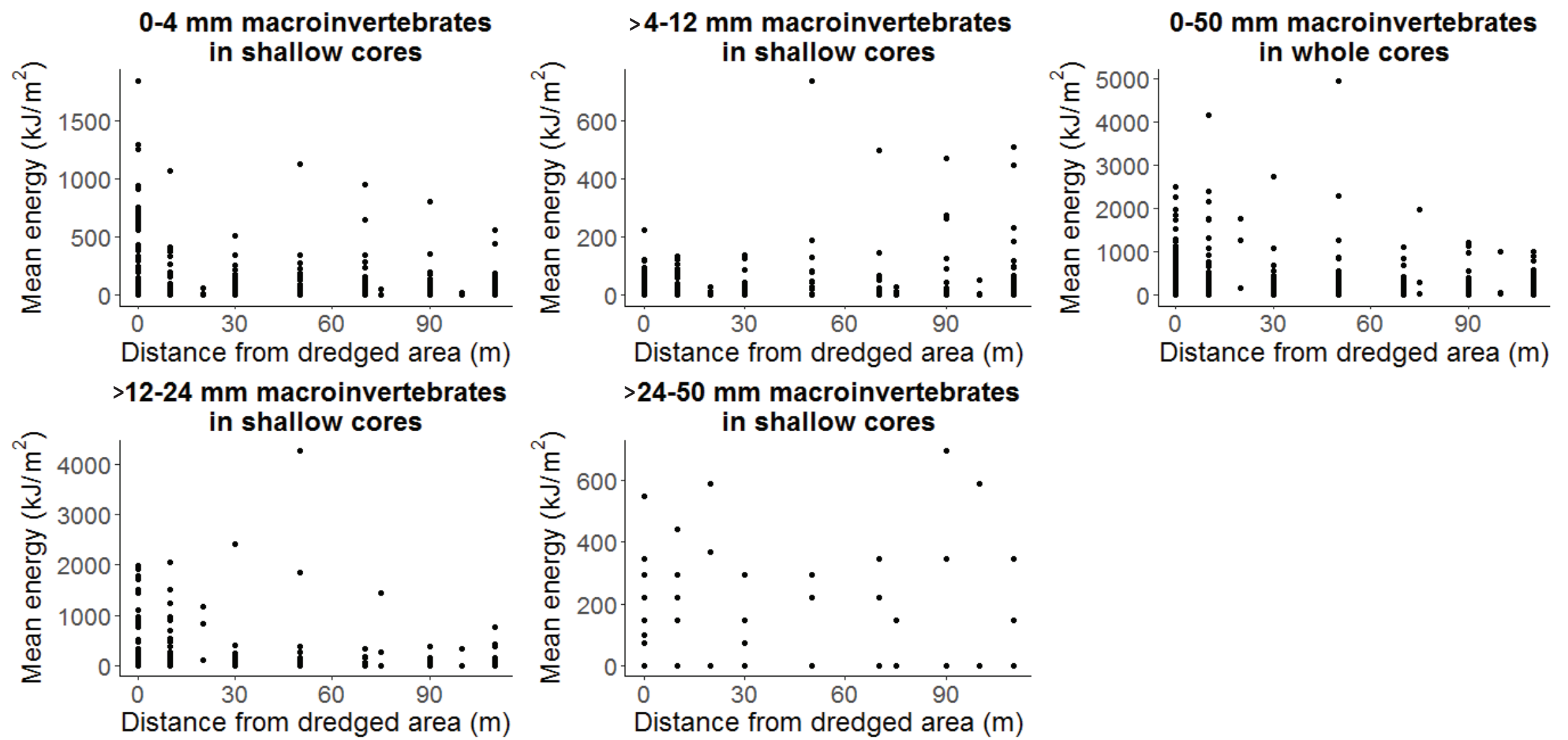

Figure 45. Change in macroinvertebrate energy (kilojoules per square meter $\left.\left[\mathrm{kJ} / \mathrm{m}^{2}\right]\right)$ by size class in shallow $(0-4$ centimeter [cm]) and whole $(0-10 \mathrm{~cm})$ core fractions with increasing distance $(\mathrm{m})$ from a dredged area. Cores were collected at six study sites (Loch Lomond, Mooring Road, Paradise Cay, Richardson Bay, Strawberry Channel, and Yacht Harbor) in San Francisco Bay. 


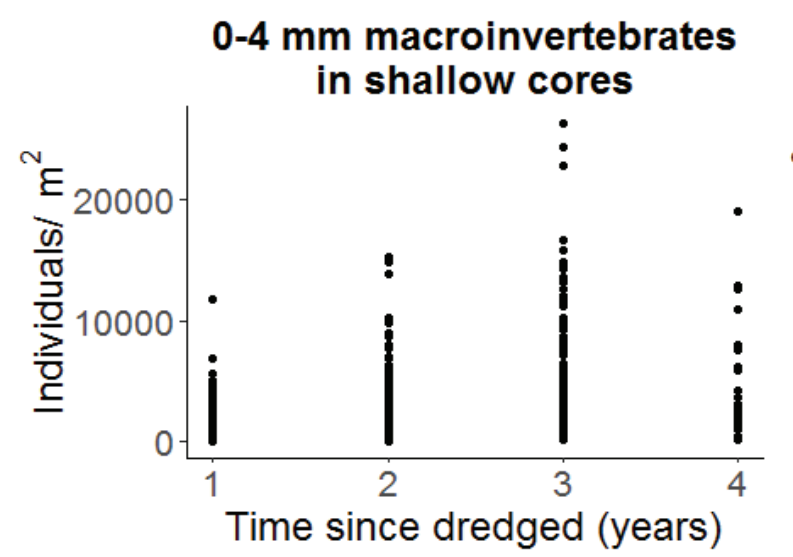

>12-24 mm macroinvertebrates in shallow cores

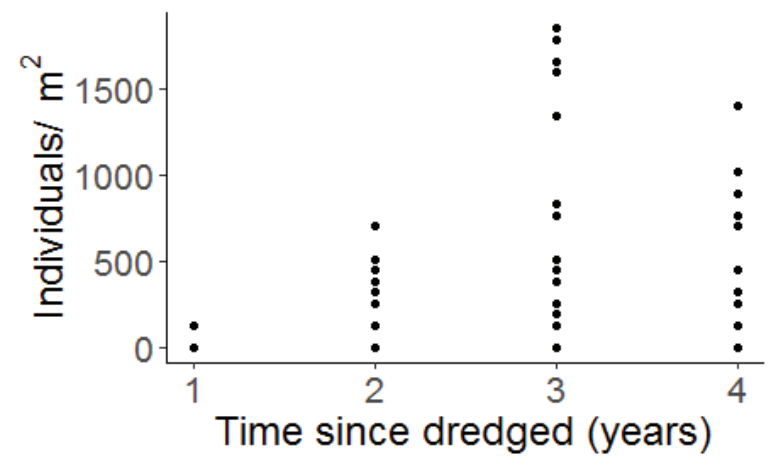

>4-12 mm macroinvertebrates in shallow cores

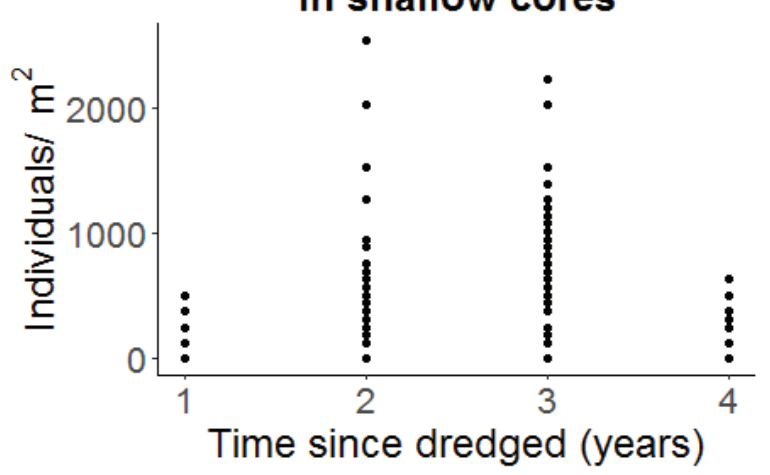

>24-50 mm macroinvertebrates

in shallow cores

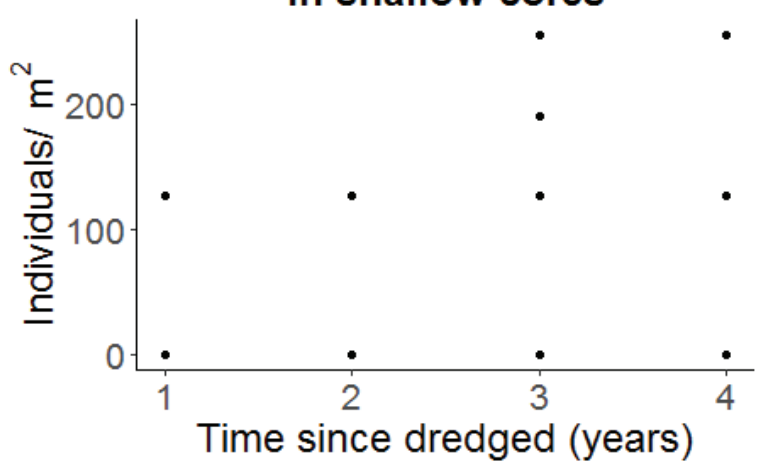

Figure 46. Change in macroinvertebrate density (individuals/square meter [ $\left.\left.\mathrm{m}^{2}\right]\right)$ by size class in shallow (0-4 centimeter [cm]) and whole $(0-10 \mathrm{~cm})$ core fractions with increasing time (years) since a site was dredged. Cores were collected at six study sites (Loch Lomond, Mooring Road, Paradise Cay, Richardson Bay, Strawberry Channel, and Yacht Harbor) in San Francisco Bay.

0-50 $\mathrm{mm}$ macroinvertebrates in whole cores

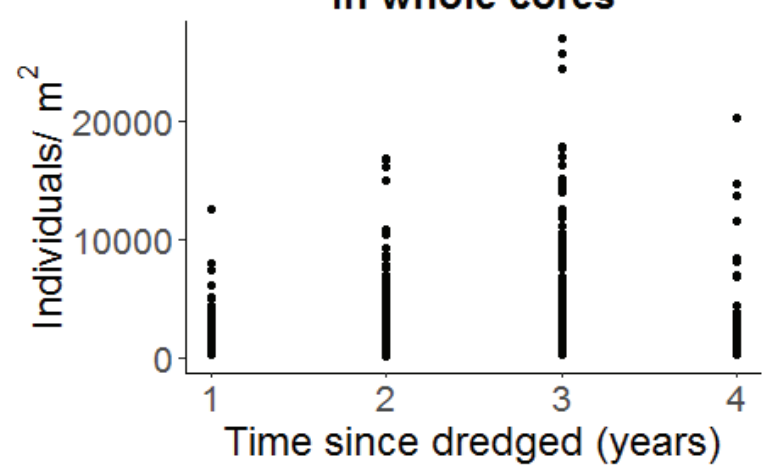




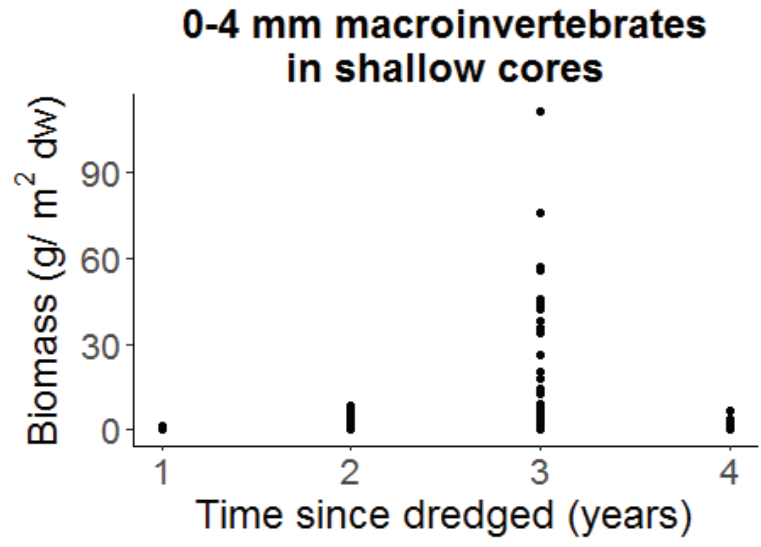

12-24 mm macroinvertebrates in shallow cores

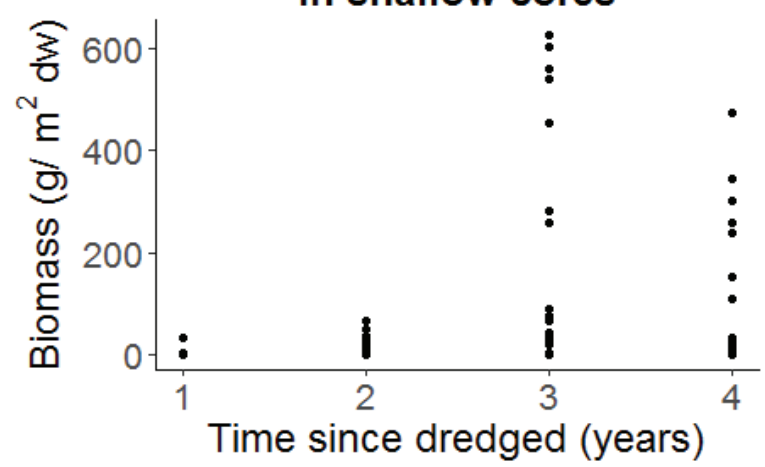

>4-12 $\mathrm{mm}$ macroinvertebrates in shallow cores

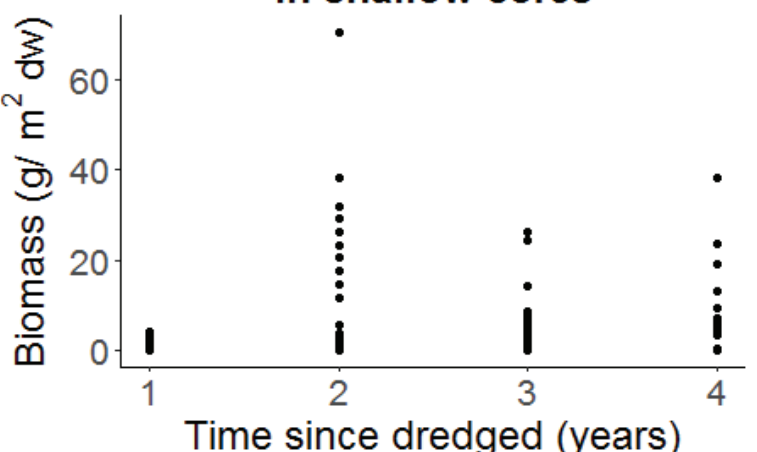

>24-50 $\mathrm{mm}$ macroinvertebrates in shallow cores

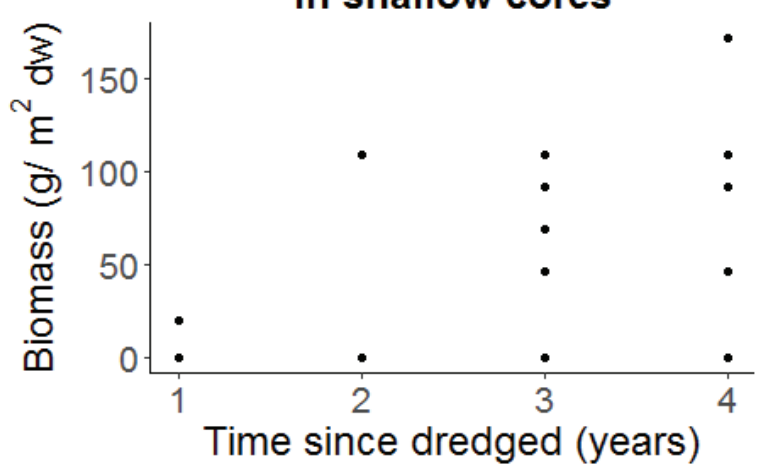

0-50 $\mathrm{mm}$ macroinvertebrates in whole cores

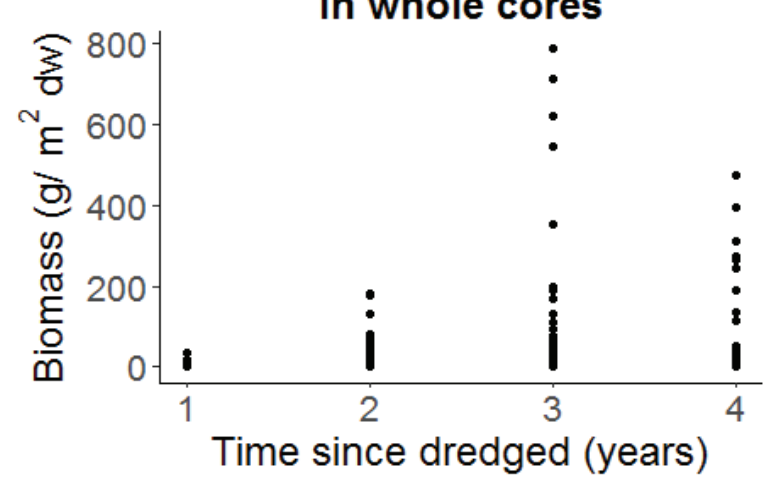

Figure 47. Change in macroinvertebrate biomass (grams per square meter dry weight $\left.\left[\mathrm{g} / \mathrm{m}^{2} \mathrm{dw}\right]\right)$ by size class in shallow $(0-4$ centimeters [cm]) and whole $(0-10 \mathrm{~cm})$ core fractions with increasing time (years) since a site was dredged. Cores were collected at six study sites (Loch Lomond, Mooring Road, Paradise Cay, Richardson Bay, Strawberry Channel, and Yacht Harbor) in San Francisco Bay. 
0-4 mm macroinvertebrates in shallow cores

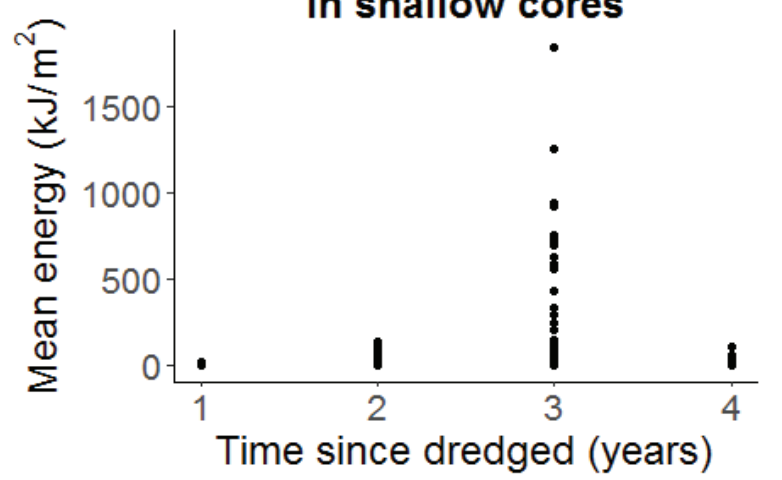

>12-24 mm macroinvertebrates

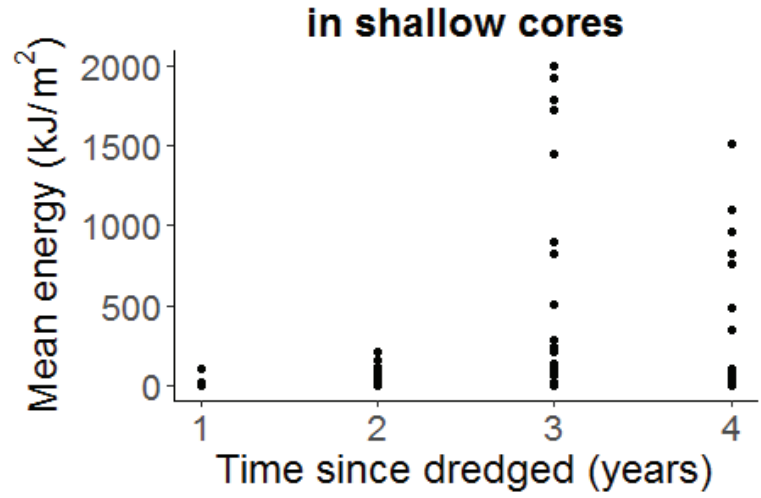

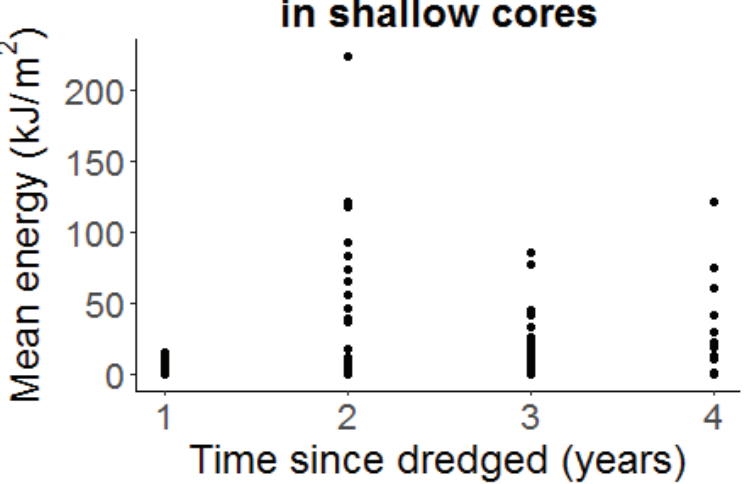

>24-50 mm macroinvertebrates

in shallow cores

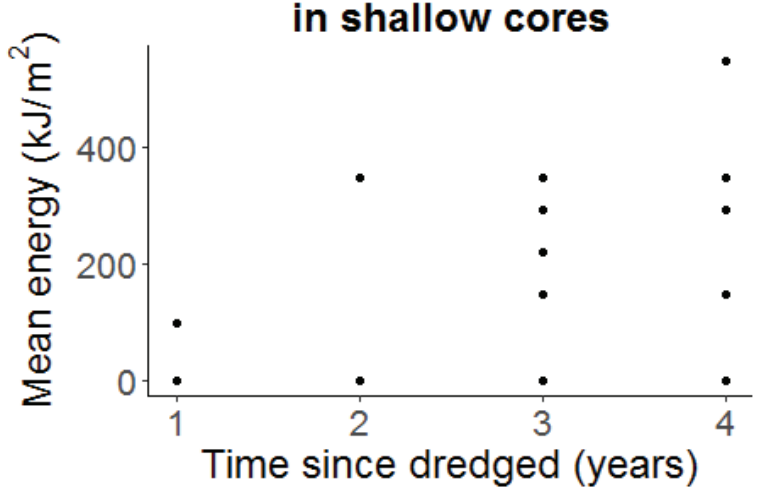

Figure 48. Change in macroinvertebrate energy (kilojoules per square meter $\left.\left[\mathrm{kJ} / \mathrm{m}^{2}\right]\right)$ by size class in shallow $(0-4$ centimeters [cm]) and whole $(0-10 \mathrm{~cm}) \mathrm{core}$ fractions with increasing time (years) since a site was dredged. Cores were collected at six study sites (Loch Lomond, Mooring Road, Paradise Cay, Richardson Bay, Strawberry Channel, and Yacht Harbor) in San Francisco Bay.

0-50 $\mathrm{mm}$ macroinvertebrates in whole cores

ฮ

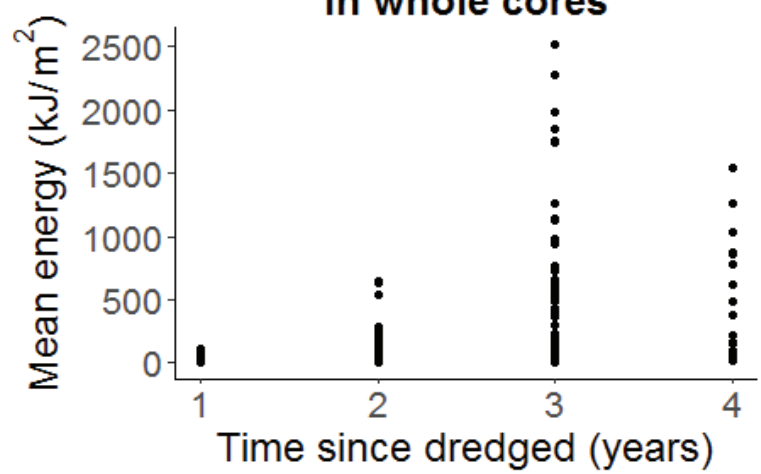

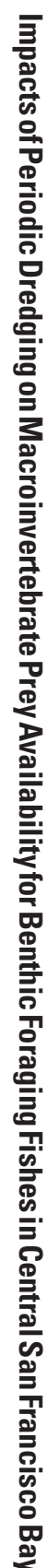




\section{Discussion}

We evaluated the effects of maintenance dredging in shallow marinas on trophic support for target benthic foraging fish species that inhabit EFH in SFB. We used a MBRAT to evaluate foraging habitat quality in terms of prey availability for target fish species. We found significantly lower density, biomass, and energy content for all available prey size classes and depths in dredged compared to adjacent undredged areas; dredged areas had lower prey availability than undredged areas for all target fish species. However, our study also demonstrated significant increases in prey density, biomass, and energy as time since dredging increased, indicating functional recovery of dredged areas for benthic foraging fishes may begin within the 3-year window that we examined in this study. Distance to dredged area also influenced biomass and energy content of some sizes of macroinvertebrate prey, such that they increased significantly as distance from dredged area increased.

Given the scope of our study, we mainly focused on functional (biomass and energy content) metrics to compare macroinvertebrate prey availability for focal fish species as a function of dredging status (dredged versus undredged), distance to dredged areas, and time-since-dredging. The MBRAT method we used is a functional metric that integrated size class, vertical distribution in the sediment, biomass, and secondary productivity (energy content) to detect changes in prey resources as a response to dredging disturbance. While we did evaluate some structural measures (density and community taxonomic structure), our study was mainly focused on trophic support for target fish species, and thus our results were not intended to compare structural and functional recovery. Functional recovery of a site can occur before the structural recovery of a macroinvertebrate community (Cooper and others, 2008), and in fact there may be no clear relationship between the two. For example, in a study of 14 dredge disposal sites in England, Bolam (2012) did not find a relationship between multivariate structural changes and taxonomic contribution to total energy production, demonstrating change in structure does not always signify a significant functional impact or vice versa. Functional traits, such as those we measured (available biomass and energy), have been advocated for assessing anthropogenic effects (Elliott and Quintino, 2007) as well as implications of dredging activities for foraging predators in mudflats (Lunz and Kendall, 1982; Bolam, 2014).

\section{Influence of Physical Characteristics}

We deliberately selected sampling sites for this study to minimize differences among them, such that inference about the effects of dredging could be maximized. Criteria for site selection required that physical characteristics such as salinity, sediment composition, and depth be within a narrow range among sites. However, localized seasonal influences, such as freshwater input from creeks, can influence site characteristics. The fact that we did find significant differences in some physical factors among sites emphasizes the importance of the localized, undredged reference areas included at each of our sampling sites to account for effects and variations that could not be completely accounted for across our sites, despite their proximity to one another.

Consistent with other studies (Boyd and others, 2005; Applied Marine Sciences Inc., 2009; Abdul Wahab and others, 2017), we found significant differences in sediment characteristics between dredged and undredged sites. Although overall, sediments from all dredged and undredged areas were characterized as loamy, we found that mean percent silt was significantly greater in undredged sediments and sand was greater in dredged sites. Benthic community assemblages can respond to differences in sediment type and particle size (Desprez, 2000; Wilber and Clarke, 2007). Fine-grained silty sediments typically have greater macroinvertebrate density and taxonomic richness (Thompson and others, 2000; Lee and others, 2003) compared to coarser sandy sediments (Thompson and others, 2007). Although our study was not designed to evaluate the role of subtle differences in sediment texture on species composition, such underlying characteristics may have contributed to the differences we measured among macroinvertebrate densities and biomass between dredged and undredged sites.

We measured a marked decrease in demersal salinity at all sites during the January 2017 sampling period compared with all other sampling periods, including the previous winter. Decreased salinity coincided with anomalous extreme rainfall and freshwater inputs to SFB (https://nwis.waterdata.usgs.gov; Swain and others, 2018) as a result of multiple large-scale storms during winter 2016-17. During our subsequent sampling period (August 2017), we observed broad taxonomic shifts in both dredged and undredged areas at all sites, including sharp decreases in polychaete, oligochaete, and bivalve densities and large increases in amphipod densities. While seasonal variation in the distribution and abundance of benthic communities in SFB is predominantly driven by annual salinity cycles, inter-annual variation, such as that seen our study, is largely influenced by Sacramento -San Joaquin River Delta outflow, local runoff, or pollution (Nichols and Pamatmat, 1988). Similar patterns have been observed in other estuaries. For example, In the Mondego estuary, Portugal, Grilo and others (2011) found prolonged flooding had a much stronger negative effect on macroinvertebrate abundance than drought in both mudflat and sandflat environments. Similar to our results, deposit and suspension feeding detritivores, such as bivalves and oligochaetes, showed the greatest decreases in abundance following prolonged freshwater inputs (Grilo and others, 2011). 
Several benthic macroinvertebrate sub-assemblages within SFB exhibit strong responses to annual variability in freshwater influx (Markmann, 1986; Peterson and Vayssieres, 2010), but Central Bay assemblages typically remain consistent. The Central Bay sustains a more diverse benthic community across seasons because the salinity regime is relatively stable and not as influenced by freshwater flows compared with other SFB regions (Thompson and others, 2000). In winter, during increased freshwater input, the surface salinity in the Central Bay can rapidly decrease (from 30 to $10 \mathrm{ppt}$ ); however, salinity values in demersal waters tend to be more stable owing to density-driven stratification (Cloern and others, 2000). Still, large freshwater influx to the Central Bay can drive spatial patterns in benthic assemblages, particularly in shallow shoal areas (Thompson and others, 2007). For example, Thompson and others (2000) found that abundance of the amphipod M. acherusicum in the Central Bay varied substantially among years and peaked in association with increased freshwater inputs. This is similar to the response we detected in amphipod abundances at all sites in summer 2017 following the intense flooding events of winter 2016-17. Although we observed dramatic shifts in taxa following these freshwater events at all but one site (Paradise Cay), the number of taxa and overall densities still were greater in undredged compared to dredged areas the following summer.

\section{The Effect of Dredging on Trophic Support for Target Fishes}

Based on an extensive literature review (De La Cruz and others, 2016), we expected the greatest levels of trophic support to co-occur with peak summer densities among most target fishes in SFB. Although many studies have noted that density and biomass for some common fish prey taxa such as amphipods (Chapman, 1988; Cohen and Carlton, 1995; Greenstein and Tiefenthaler, 2013) and bivalves (Radtke, 1966; McKechnie and Fenner, 1971; Haderlie and Abbott, 1980; Emmett and others, 1991; Thompson and others, 2007) are higher during summer compared to winter months, we observed temporal variations in macroinvertebrate patterns that were independent of dredging status and were more likely driven by anomalous freshwater events (see discussion of physical characteristics above).

Similar to other studies (Hirsch and others, 1978; LaSalle, 1990; Clarke and others, 2000; Dernie and others, 2003; Wilber and others, 2008; Lebednik, 2004; Rich, 2010), we found dredged areas had significantly less macroinvertebrate density, biomass, and energy content compared to paired undredged areas, resulting in lower overall trophic support for target fish species. However, the degree of impact depended on the macroinvertebrate size class consumed and the foraging depth of each target fish species. For example, juvenile Pacific sardine, longfin smelt, northern anchovy, and brown rockfish that consume the smallest prey size class $(0-4 \mathrm{~mm})$ and forage within the shallow benthos $(0-4 \mathrm{~cm}$ depth) had the lowest mean prey biomass and energy available compared with all other target species and age classes. Both available biomass and energy were 44 percent less in dredged areas compared to undredged areas that were accessible to these fishes. Larger fishes and adult life stages that were able to exploit all macroinvertebrate size classes and both shallow and deep depths had more prey available to them at dredged sites, but this still represented an average of 41 percent less biomass and 50 percent less energy than at undredged sites. Interestingly, the greatest reduction (51 percent) of available mean biomass in dredged areas occurred for fish that forage on the smallest two size classes of macroinvertebrates ( $0-4$ and 4-12 $\mathrm{mm})$ in shallow sediments, such as juvenile English sole and juvenile starry flounder. Fish species that were least impacted by dredging ( 35 percent reduction in biomass and 40 percent reduction in energy compared to undredged) included those that forage on small and intermediate size classes $(0-4,4-12$, and $12-24 \mathrm{~mm}$ ) in shallow sediments, such as adult Pacific sardine and adult longfin smelt.

As expected, based on our pilot work and previous studies (Clarke, 1986), we found that macroinvertebrate densities and biomass were concentrated in the top $0-4 \mathrm{~cm}$ of cores in both dredged and undredged areas, though in many undredged areas a large proportion of the total biomass occurred in deeper fractions of the core. Concentration of prey at the surface often occurs in the early stages of succession post dredging and in some cases can increase prey availability for fish species (Rhoads and Germano, 1986). Later successional stage macroinvertebrates are typically larger, longer-lived species that can burrow deeper in the sediment (Rhoads and Germano, 1986). For example, we found most of the biomass and energy in whole cores from undredged areas was contributed by intermediate 12-24 mm bivalves or $0-4 \mathrm{~mm}$ (head width) polychaetes. Although fewer in number, intermediate to large-sized (12-24 and 24-50) macroinvertebrates can be important, high-caloric prey for deep, benthic-foraging, target fishes such as leopard shark, Dungeness crab, sturgeon, and skates (Talent, 1976; Barry, 1983; Barry and others, 1996; Adams and others, 2002; Ebert and Ebert, 2005; Yang, 2007; Bizzarro and others, 2007; Israel and Klimley, 2008; De La Cruz and others, 2016). In fact, across all undredged areas and time periods, deep core fractions provided up to 15 percent more available prey biomass and energy for species that could access this depth than the maximum biomass and energy contained in shallow core fractions from undredged areas. 


\section{The of Effects of Distance and Time}

We found that macroinvertebrate density, biomass, and energy varied by distance from a dredged area. The density of the smallest macroinvertebrate size class $(0-4 \mathrm{~mm})$ at the surface ( $0-4 \mathrm{~cm}$ deep) decreased significantly the farther we sampled from a dredged area, and biomass and energy content of larger size classes at deeper depths increased with distance from dredged area. For small-scale disturbances that result in the localized removal of macroinvertebrates in adjacent areas, one way to evaluate the effect of a dredging operation is to evaluate the dispersal capacity of colonizing organisms (Günther, 1992). Organisms with prolonged larval periods that include a pelagic stage, such as crab and bivalve species, may have a relatively greater capacity for longer-distance dispersal and recolonization compared to macroinvertebrate taxa with crawling or brooding larvae, such as many polychaete species, that may disperse as juveniles or adults (Lundquist and others, 2004). Günther (1992) found that localized disturbances were associated with the dispersal and recolonization by post-larval life stages and to a lesser degree immigration of adults, whereas in larger disturbed sites, recovery was predominately from the dispersal of long-distance planktonic larvae. Lundquist and others (2004) conducted simulations with a hydrodynamic and particle-tracking model and predicted that small larvae would disperse farther than larger, heavier larvae and juveniles. At our sites, the greatest densities and biomass of the smallest macroinvertebrate species were found closer to dredged areas, while larger species increased with increasing distance from the dredge area, indicating maintenance dredging may have created localized disturbance that impacted the size class, depth, biomass, and energy content of adjacent benthic communities at short distances. Fishes that forage on the smallest prey on the sediment surface (such as, juvenile Pacific sardine, juvenile longfin smelt, juvenile rockfish) may in some cases benefit from such disturbance, while larger fishes that consume larger prey $(0-24 \mathrm{~mm}$ or $0-50 \mathrm{~mm})$ at the surface or to $10-\mathrm{cm}$ depth (such as. adult northern anchovy, adult starry flounder, adult brown rockfish, adult California halibut) may experience reduced available prey resources.

By incorporating marinas that were dredged at 1,2, and 3 years prior to our study, we were able to examine how quickly structural and functional metrics of benthic habitat for foraging fish might begin to approximate those of adjacent undredged areas. We found that macroinvertebrate density, biomass, and energy content within every size class and depth, except density of 0-4 $\mathrm{mm}$ prey and energy from 12 to $24 \mathrm{~mm}$ prey in shallow sediments, increased with time-since-dredging. From the standpoint of trophic support for fishes, our findings indicate an increase in available prey coincided with time-since-dredging for most species and ages of target fishes. However, after repeatedly sampling the same sites during four sampling periods across 2 years, we found that overall prey density, biomass, and energy in dredged areas only approximated that of undredged areas at two sites, Mooring Road and Paradise Cay, dredged 3 and 2 years prior to the study's inception. Thus, whereas a site may begin to be recolonized shortly after dredging, our study indicated it can take more than 1 to 3 years for a site to recover trophic functions that approximate those of adjacent undredged areas.

Defining benthic recovery and determining the time required for recovery remains a major challenge for the scientific community (Rhoads and Germano, 1986; Bolam and Rees, 2003; Wilber and Clarke, 2007; Wilber and others, 2008). Recovery is often defined as the return of a dredged area to a baseline, pre-impact, or, like the local undredged areas that we evaluated in this study, some definable reference state. Limited information exists about benthic community recovery from dredge disturbance in $\mathrm{SFB}$, and no previous SFB studies have evaluated recovery of relative foraging value for benthic fishes. In contrast to our study conducted in shallow, fine-grained sediment marinas, a sand mining study in deep-water channels within the Central Bay indicated no significant differences in number of taxa or abundance between control areas and areas mined within the previous 3 years (Applied Marine Sciences Inc., 2009). Kenny and Rees (1994) monitored recolonization of a benthic community after a dredge event in the North Sea and observed similar rapid recolonization rates as in our study, but no notable increase in biomass, which in their study indicated the loss of large taxa. At our sites, we observed lower biomass and energy content among larger prey size classes in dredged areas, particularly at sites dredged 1 to 2 years before our study. 


\section{Summary}

We measured macroinvertebrate density, biomass, and energy content in adjacent dredged and undredged areas at six Central Bay shallow marinas dredged during 2013, 2014, or 2015 to evaluate trophic support for SFB benthic foraging fishes in relationship to: (1) dredged versus undredged locations, (2) distance to dredged areas, and (3) years since dredging. We found several implications for foraging target fish species using these habitats:

- Low salinity events in the Central Bay during winter 2016-17 resulted in broad taxonomic shifts in both dredged and undredged areas at all sites, including sharp decreases in polychaete, oligochaete, and bivalve densities and large increases in amphipod densities. At all but one site (Paradise Cay), the number of taxa and overall densities were greater in undredged compared to dredged areas during the following summer sampling period.

- We detected 104 unique taxa in the shallow $(0-4 \mathrm{~cm})$ depth compared to 43 unique taxa in the deep $(4-10 \mathrm{~cm})$ depth range. We found a greater taxonomic richness in undredged areas compared to dredged areas.

- Overall, in comparison to undredged reference areas, dredged areas had lower trophic support for all species and ages of fishes included in our study.

- There appeared to be differential impacts of dredging on trophic support for fishes based on macroinvertebrate size class that can be consumed and the depth to which certain fish can forage. For example, fish species that forage on the two smallest size classes of macroinvertebrates (0-4 and 4-12 mm) in shallow benthic habitats, namely juvenile English sole and juvenile starry flounder, experienced the greatest potential impact (51 percent decline in available prey biomass in dredged compared to undredged areas). While fish that were able to exploit small and intermediate prey size classes $(0-4,4-12$, and $12-24 \mathrm{~mm}$ ) in shallow benthic habitats, such as adult Pacific sardine and adult longfin smelt, only experienced a 35 percent reduction in biomass at dredge compared to undredged areas.

- The impact of distance from a dredged area varied by prey size class. Density, biomass, and energy content of the smallest prey size class $(0-4 \mathrm{~mm})$ increased closest to dredge disturbance, while larger macroinvertebrate prey resources $(12-24 \mathrm{~mm}$ and $24-50 \mathrm{~mm}$ ) had increasing biomass associated with increasing distance from a dredged area.

- In general, macroinvertebrate density, biomass, and energy content within every size class and depth, except density of $0-4 \mathrm{~mm}$ prey in shallow sediments, increased with time-since-dredging.

- We found a positive effect of time-since-dredging on macroinvertebrate density, biomass, and energy content such that all three increased for most size classes and depths over time; however, there was little evidence that these measures in dredged areas were equivalent to those of undredged areas within the one to three-year time window we examined. 


\section{References Cited}

Abdul Wahab, M.A., Fromont, J., Gomez, O., Fisher, R., and Jones, R., 2017, Comparisons of benthic filter feeder communities before and after a large-scale capital dredging program: Marine Pollution Bulletin, v. 122, no. 1-2, p. 176-193, https://doi.org/10.1016/j.marpolbul.2017.06.041.

Ackerman, L.T., 1971, Contributions to the biology of the leopard shark, Triakis semifasciata (Girard) in Elkhorn Slough, Monterey Bay, California: California State University, Sacramento, $61 \mathrm{p}$.

Adams, P.B., Grimes, C.B., Hightower, J.E., Lindley, S.T., and Moser, M.L., 2002, Status review for North American green sturgeon, Acipenser medirostris: Santa Cruz, Calif., National Marine Fisheries Service, 50 p.

Allen, L.G., 1988, Recruitment, distribution, and feeding habits of young-of-the-year California halibut (Paralichthys californicus) in the vicinity of Alamitos Bay-Long Beach Harbor, California, 1983-1985: Bulletin of the Southern California Academy of Sciences, v. 87, p. 19-30.

Ambrose, D.A., 1976, The distribution, abundance, and feeding ecology of four species of flatfish in the vicinity of Elkhorn Slough, California: Thesis, San Jose State University, $121 \mathrm{p}$.

Applied Marine Sciences Inc, 2009, Benthic survey of commercial aggregate mining leases in central San Francisco Bay and western Delta. In, California State Lands Commission, Final Environmental Impact Report, San Francisco Bay and Delta Sand Mining Project, Appendix F: California State Clearninghouse, No 2007072036, 58 p., https://www.slc.ca.gov/ceqa/sf-delta-sand-mining.

Barnard, P.L., Schoellhamer, D.H., Jaffe, B.E., and McKee, L.J., 2013, Sediment transport in the San Francisco Bay coastal system-An overview: Marine Geology, v. 345, p. 3-17, https://doi.org/10.1016/j.margeo.2013.04.005.

Barry, J.P., 1983, Utilization of shallow marsh habitats by fishes in Elkhorn Slough: California, San Jose State University, 107 p., http://islandora.mlml.calstate.edu/ islandora/object/islandora $\% 3 \mathrm{~A} 461 /$ datastream/OBJ/ download/Utilization_of_shallow_marsh_habitats_by_ fishes_in_Elkhorn_Slough_California.pdf.

Barry, J.P., Yoklavich, M.M., Cailliet, G.M., Ambrose, D.A., and Antrim, B.S., 1996, Trophic ecology of the dominant fishes in Elkhorn Slough, California, 1974-1980: Estuaries, v. 19, no. 1, p. 115-138, https://doi.org/10.2307/1352657.

Baxter, R., 2009, A status review of the longfin smelt (Spirinchus thaleichthys) in California: Department of Fish and Game, 131 p., https://deltarevision.com/2002_docs/ LongfinSmeltStatusReview.pdf.
Baxter, R., Hieb, K., DeLeon, S., Fleming, K., and Orsi, J., 1999, Report on the 1980-1995 fish, shrimp, and crab sampling in the San Francisco Estuary, California: Interagency Ecological Program for the Sacramento-San Joaquin Estuary, 503 p.

Bizzarro, J.J., Robinson, H.J., Rinewalt, C.S., and Ebert, D.A., 2007, Comparative feeding ecology of four sympatric skate species off central California, USA: Environmental Biology of Fishes, v. 80, no. 2-3, p. 197-220, accessed March 24, 2014, at https://doi.org/10.1007/s10641-007-9241-6.

Bizzarro, J.J., Yoklavich, M.M., and Wakefield, W.W., 2017, Diet composition and foraging ecology of U.S. Pacific Coast groundfishes with applications for fisheries management: Environmental Biology of Fishes, v. 100, no. 4, p. 375-393, https://doi.org/10.1007/s10641-016-0529-2.

Blaxter, J.H.S., and Hunter, J.R., 1982, The biology of clupeoid fishes: Advances in Marine Biology, v. 20, p. 1-223, https://doi.org/10.1016/S0065-2881(08)60140-6.

Bogacka-Kapusta, E., Wiszniewski, G., Duda, A., and Kapusta, A., 2011, Feeding of hatchery-reared juvenile Atlantic sturgeon, Acipenser oxyrinchus Mitchill, released into the Drwęca River: Archives of Polish Fisheries, v. 19, no. 2, p. 113-117, https://doi.org/10.2478/v10086-011-0013-8.

Bolam, S.G., 2012, Impacts of dredged material disposal on macrobenthic invertebrate communities - A comparison of structural and functional (secondary production) changes at disposal sites around England and Wales: Marine Pollution Bulletin, v. 64, no. 10, p. 2199-2210: Elsevier Ltd., accessed March 20, 2014, at https:/www.ncbi.nlm.nih.gov/pubmed/22935522.

Bolam, S.G., 2014, Macrofaunal recovery following the intertidal recharge of dredged material-A comparison of structural and functional approaches: Marine Environmental Research, Elsevier Ltd, v. 97 p. 15-29, accessed March 21, 2014, at https://www.ncbi.nlm.nih.gov/pubmed/24534437.

Bolam, S.G., and Rees, H.L., 2003, Minimizing impacts of maintenance dredged material disposal in the coastal environment-A habitat approach: Environmental Management, v. 32, no. 2, p. 171-188, https://doi.org/10.1007/s00267-003-2998-2.

Bolam, S.G., Rees, H.L., Somerfield, P., Smith, R., Clarke, K.R., Warwick, R.M., Atkins, M., and Garnacho, E., 2006, Ecological consequences of dredged material disposal in the marine environment - A holistic assessment of activities around the England and Wales coastline: Marine Pollution Bulletin, v. 52, no. 4, p. 415-426, https://doi.org/10.1016/j.marpolbul.2005.09.028. 
Bottom, D.L., and Jones, K.K., 1990, Species composition, distribution, and invertebrate prey of fish assemblages in the Columbia River Estuary: Progress in Oceanography, v. 25, no. 1-4, p. 243-270, https://doi.org/10.1016/0079-6611(90)90009-Q.

Boubee, J.A.T., and Ward, F.J., 1997, Mouth gape, food size, and diet of the common smelt Retropinna retropinna (Richardson) in the Waikato River system, North Island, New Zealand: New Zealand Journal of Marine and Freshwater Research, v. 31, no. 2, p. 147-154, https://doi.org/10.1080/00288330.1997.9516753.

Boyd, S.E., Limpenny, D.S., Rees, H.L., and Cooper, K.M., 2005, The effects of marine sand and gravel extraction on the macrobenthos at a commercial dredging site (results 6 years post-dredging): ICES Journal of Marine Science, v. 62, no. 2, p. 145-162, https://doi.org/10.1016/j.icesjms.2004.11.014.

Brey, T., 2001, Population dynamics in benthic invertebrates-A virtual handbook: Version 01.2, http://www.thomas-brey.de/science/virtualhandbook.

Brey, T., Rumohr, H., and Ankar, S., 1988, Energy content of macrobenthic invertebrates-General conversion factors from weight to energy: Journal of Experimental Marine Biology and Ecology, v. 117, no. 3, p. 271-278, https://doi.org/10.1016/0022-0981(88)90062-7.

Buechner, H., Matheson, L., and Simenstad, C.A, 1981, Food web relationships of juvenile salmonids and English sole, section 8.0 in Simenstad, C.A., and Eggers, D.M., eds., Juvenile salmonid and baitfish distribution, abundance, and prey resources in selected areas of Grays Harbor, Washington: University of Washington, Fisheries Research Institute, p. 146-185.

Burnham, K.P., and Anderson, D.R., 2002, Model selection and multimodel inference-A practical information-theoretic approach 2nd ed.: New York, Springer-Verlag, 515 p., http://ecologia.ib.usp.br/bie5782/ lib/exe/fetch.php?media=bie5782:pdfs:burnham anderson2002.pdf.

California Department of Fish and Wildlife, 2013, San Francisco Bay Study - 1980-2012 dataset: available from http://www.dfg.ca.gov/delta/ProjectDescription.asp? ProjectID=BAYSTUDY.

California State Coastal Conservancy, California Ocean Protection Council, NOAA National Marine Fisheries Service and Restoration Center, San Francisco Bay Conservation and Development Commission, and San Francisco Estuary Partnership, 2010, San Francisco Bay subtidal habitat goals report; Conservation planning for the submerged areas of the bay; 50-year conservation plan: California State Coastal Conservancy, 180 p., http://www.sfbaysubtidal.org/PDFS/Full\%20Report.pdf.
Cardoso, I., Granadeiro, J.P., and Cabral, H., 2010, Benthic macroinvertebrates' vertical distribution in the Tagus estuary (Portugal) - The influence of tidal cycle: Estuarine, Coastal and Shelf Science, v. 86, no. 4, p. 580-586, https://doi.org/10.1016/j.ecss.2009.11.024.

Cauffope, G., and Heymans, S.J.J., 2005, Energy contents and conversion factors for sea lion's prey, in Guenette, S., and Christensen, V., eds., Food web models and data for studying fisheries and environmental impacts on Eastern Pacific ecosystems - Fisheries Centre Research Reports v. 13: Canada, University of British Columbia, p. 225-237.

Chapman, J.W., 1988, Invasions of the northeast Pacific by Asian and Atlantic Gammaridean amphipod crustaceans, including a new species of Corophium: Journal of Crustacean Biology, v. 8, no. 3, p. 364-382, https://doi.org/10.1163/193724088X00242.

Chigbu, P., Sibley, T.H., and Beauchamp, D.A., 1998, Abundance and distribution of Neomysis mercedis and a major predator, longfin smelt (Spirinchus thaleichthys) in Lake Washington: Hydrobiologia, v. 386, no. 1-3, p. 167-182, https://doi.org/10.1023/A:1003537122340.

Clarke, D.G., 1986, Benthic resources assessment technique evaluation of disposal sites in Puget Sound and adjacent waters: U.S. Corps of Engineers, Vicksburg, Miss., 72 p., https://apps.dtic.mil/dtic/tr/fulltext/u2/a184926.pdf.

Clarke, D.G., Ray, G.L., and Bass, R.J., 1993, Benthic recovery on experimental dredged material disposal mounds in Galveston Bay, Texas: The Second State of the Bay Symposium, February 4-6, 1993, p. 191-197.

Clarke, D.G., Engler, R.M., and Wilber, D.H., 2000, Assessment of potential impacts of dredging operations due to sediment resuspension: DOER, Army Engineer Waterways Experiment Station, Vicksburg, Miss., ERDC-TN-DOER-E9, 14 p., https://apps.dtic.mil/dtic/tr/fulltext/u2/a377325.pdf.

Cloern, J.E., Cole, B.E., Edmunds, J.L., Schraga, T.S., and Arnsberg, A., 2000, Patterns of water-quality variability in San Francisco Bay during the first six years of the RMP, 1993-1998: San Francisco Estuary Institute, RMP no. 41, 19 p., https://www.sfei.org/sites/default/files/biblio_files/ patterns.pdf.

Cohen, A.N., 2010, Habitat stressor narrative descriptions, appendix 2-1 of San Francisco Bay subtidal habitat goals report: Oakland, Calif., San Francisco Estuary Institute, 94 p., http://www.sfbaysubtidal.org/PDFS/Ap2-1\%20 Habitat\%20Stressors.pdf. 
Cohen, A.N., and Carlton, J.T., 1995, Nonindigenous aquatic species in a United States estuary-A case study of the biological invasions of the San Francisco Bay and Delta: Washington, D.C., U.S. Fish and Wildelife Service, http://bioinvasions.org/wp-content/uploads/1995-SFBayInvasion-Report.pdf.

Cohen, A.N., and Carlton, J.T., 1998, Accelerating invasion rate in a highly invaded estuary: Science, v. 279 , no. 5350 , p. 555-558, https://doi.org/10.1126/science.279.5350.555.

Conomos, T.J., Smith, R.E., and Gartner, J.W., 1985, Environmental setting of San Francisco Bay, in Cloern, J.E., and Nichols, F.H., eds., Temporal dynamics of an estuarySan Francisco Bay: Dordrecht, The Netherlands, Springer, p. 1-12, https://doi.org/10.1007/978-94-009-5528-8_1.

Cooper, K.M., Barrio Froján, C.R.S., Defew, E., Curtis, M., Fleddum, A., Brooks, L., and Paterson, D.M., 2008, Assessment of ecosystem function following marine aggregate dredging: Journal of Experimental Marine Biology and Ecology, v. 366, no. 1-2, p. 82-91, https://doi.org/10.1016/j.jembe.2008.07.011.

Crowder, L.B., and Cooper, W.E., 1982, Habitat structural complexity and the interaction between Bluegills and their prey: Ecology, v. 63, no. 6, p. 1802-1813, https://doi.org/10.2307/1940122.

Cumminns, K.W., and Wuycheck, J.C., 1971, Caloric equivalents for investigations in ecological energetics: Internationale Vereinigung für Theoretische und Angewandte Limnologie: Mitteilungen, v. 18, no. 1, p. 1-158, https://doi.org/10.1080/05384680.1971.11903918.

Currie, D.R., and Parry, G.D., 1996, Effects of scallop dredging on a soft sediment community-A large-scale experimental study: Marine Ecology Progress Series, v. 134, p. 131-150, https://doi.org/10.3354/meps 134131.

De La Cruz, S.E.W., Woo, I., Hobbs, J., Loveland, A., Donald, J., and Takekawa, J.Y., 2016, A review of Central San Francisco Bay foraging fish and their benthic prey resources: Berkeley, California, U.S. Geological Survey Administrative Report to San Francisco Estuary Institute, $121 \mathrm{p}$.

De La Cruz, S.E.W., Woo, I., Flanagan, A., Mittelstaedt, H., and Donald, J., 2017, Assessing the impact of periodic dredging on macroinvertebrate-prey availability for benthic foraging fishes-Final study plan and preliminary pilot study results: Report to the San Francisco Estuary Institute Regional Monitoring Program, 65 p., https:/www.sfei.org/ sites/default/files/biblio_files/USGS\%20Benthic $\% 20$ Recovery\%20Project\%20Final\%20Report_0.pdf.
Dernie, K.M., Kaiser, M.J., and Warwick, R.M., 2003, Recovery rates of benthic communities following physical disturbance: Journal of Animal Ecology, v. 72, no. 6, p. 1043-1056, https://doi.org/10.1046/j.1365-2656.2003.00775.x.

Desprez, M., 2000, Physical and biological impact of marine aggregate extraction along the French coast of the Eastern English Channel-Short- and long-term post-dredging restoration: ICES Journal of Marine Science, v. 57, no. 5, p. 1428-1438, https://doi.org/10.1006/jmsc.2000.0926.

Di Stefano, J., 2003, How much power is enough? Against the development of an arbitrary convention for statistical power calculations: Functional Ecology, v. 17, no. 5, p. 707-709, https://doi.org/10.1046/j.1365-2435.2003.00782.x.

Dumbauld, B.R., Holden, D.L., and Langness, O.P., 2008, Do sturgeon limit burrowing shrimp populations in Pacific Northwest Estuaries?: Environmental Biology of Fishes, v. 83, no. 3, p. 283-296, https://doi.org/10.1007/s10641-008-9333-y.

Ebert, D.A., and Ebert, T.B., 2005, Reproduction, diet and habitat use of leopard sharks, Triakis semifasciata (Girard), in Humboldt Bay, California, USA: Marine and Freshwater Research, v. 56, no. 8, p. 1089-1098, https://doi.org/10.1071/MF05069.

Elliott, M., and Quintino, V., 2007, The estuarine quality paradox, environmental homeostasis and the difficulty of detecting anthropogenic stress in naturally stressed areas: Marine Pollution Bulletin, v. 54, no. 6, p. 640-645, https://doi.org/10.1016/j.marpolbul.2007.02.003.

Emmett, R.L., Hinton, S.A., Stone, S.L., and Monaco, M.E., 1991, Distribution and abundance of fishes and invertebrates in west coast estuaries - Volume II Species life history summaries: U.S. Department of Commerce, NOAA's Estuarine Living Marine Resources Program, Rockville, Md., ftp://ftp.library.noaa.gov/noaa documents.lib/NOS/ORCA/ELMR_report/ELMR_11.pdf.

Emmett, R.L., Brodeur, R.D., Miller, T.W., Pool, S.S., Krutzikowsky, G.K., Bentley, P.J., and McCrae, J., 2005, Pacific sardine (Sardinops sagax) abundance, distribution, and ecological relationships in the Pacific Northwest: Page California Cooperative Oceanic Fisheries Investigations Report, v. 46, p. 122-143, https:/www.calcofi.org/ publications/calcofireports/v46/Vol_46_Emmett_et_al_ Pacific_Sardine.pdf.

Espinoza, P., Bertrand, A., van der Lingen, C.D., Garrido, S., and Rojas de Mendiola, B., 2009, Diet of sardine (Sardinops sagax) in the northern Humboldt current system and comparison with the diets of clupeoids in this and other eastern boundary upwelling systems: Progress in Oceanography, v. 83, no. 1-4, p. 242-250, https://doi.org/10.1016/j.pocean.2009.07.045. 
Ferraro, S.P., and Cole, F.A., 2004, Optimal benthic macrofaunal sampling protocol for detecting differences among four habitats in Willapa Bay, Washington, USA: Estuaries, v. 27, no. 6, p. 1014-1025, https://doi.org/10.1007/BF02803427.

Ferry-Graham, L.A., 1998, Effects of prey size and mobility on prey-capture kinematics in leopard sharks Triakis semifasciata: The Journal of Experimental Biology, v. 201, p. 2433-2444, https://jeb.biologists.org/content/201/16/2433.

Feyrer, F., Herbold, B., Matern, S.A., and Moyle, P.B., 2003, Dietary shifts in a stressed fish assemblage - Consequences of a bivalve invasion in the San Francisco Estuary: Environmental Biology of Fishes, v. 67, no. 3, p. 277-288, https://doi.org/10.1023/A:1025839132274.

Gadomski, D.M., and Boehlert, G.W., 1984, Feeding ecology of pelagic larvae of English sole Parophrys vetulus and butter sole Isopsetta isolepis off the Oregon coast: Marine Ecology Progress Series, v. 20, p. 1-12, https://doi.org/10.3354/meps020001.

Gessner, J., Van Eenennaam, J.P., and Doroshov, S.I., 2007, North American green and European Atlantic sturgeon-Comparisons of life histories and human impacts: Environmental Biology of Fishes, v. 79, no. 3-4, p. 397-411, https://doi.org/10.1007/s10641-006-9073-9.

Gillet, D.J., Ranasinghe, J.A., and Stein, E.D., 2014, Development of benthic community condition indicesSan Francisco Bay_Phase I Final Report: Richmond, Calif., Contract \#1038, San Francisco Estuary Institute, Contribution \# 735, 19 p., https://www.sfei.org/sites/default/ files/biblio_files/735_SCCWRP_Mesohaline_Benthic_ Index_Report_Final.pdf.

Goals Project, 1999, Baylands ecosystem habitat goals-A report of habitat recommendations prepared by the San Francisco Bay Area Wetlands Ecosystem Goals Project: Oakland, Calif., U.S. Environmental Protection Agency, San Francisco, Calif./San Francisco Bay Regional Water Quality Control, https://sfestuary.org/wp-content/uploads/2012/12/ 1Habitat_Goals.pdf.

Godin, J.-G.J., and Keenleyside, M.H.A., 1984, Foraging on patchily distributed prey by a cichlid fish (Teleostei, Cichlidae) - A test of the ideal free distribution theory: Animal Behaviour, v. 32, no. 1, p. 120-131, https://doi.org/10.1016/S0003-3472(84)80330-9.
Goss-Custard, J.D., West, A.D., Yates, M.G., Caldow, R.W., Stillman, R.A., Bardsley, L., Castilla, J., Castro, M., Dierschke, V., Durell, S.E., Eichhorn, G., Ens, B.J., Exo, K.M., Udayangani-Fernando, P.U., Ferns, P.N., Hockey, P.A., Gill, J.A., Johnstone, I., Kalejta-Summers, B., Masero, J.A., Moreira, F., Nagarajan, R.V., Owens, I.P., Pacheco, C., Perez-Hurtado, A., Rogers, D., Scheiffarth, G., Sitters, H., Sutherland, W.J., Triplet, P., Worrall, D.H., Zharikov, Y., Zwarts, L., and Pettifor, R.A., 2006, Intake rates and the functional response in shorebirds (Charadriiformes) eating macro-invertebrates: Biological Reviews of the Cambridge Philosophical Society, v. 81, no. 4, p. 501-529, https://doi.org/10.1111/j.1469-185X.2006.tb00216.x.

Gotshall, D.W., 1977, Stomach contents of northern California dungeness crabs, Cancer magister: California Fish and Game, v. 63, no. 1, p. 43-51.

Greene, H.G., Endris, C., Vallier, T., Golden, N., Cross, J., Ryan, H., Dieter, B., and Niven, E., 2013, Sub-tidal benthic habitats of central San Francisco Bay and offshore Golden Gate area-A review: Marine Geology, v. 345, p. 31-46, https://doi.org/10.1016/j.margeo.2013.05.001.

Greenstein, D.J., and Tiefenthaler, L.L., 2013, Reproduction and population dynamics of Grandidierella japonica (Stephensen) (Crustacea-Amphipoda) in upper Newport Bay: Bulletin of the Southern California Academy of Sciences, v. 96, no. 1, p. 34-42.

Grilo, T.F., Cardoso, P.G., Dolbeth, M., Bordalo, M.D., and Pardal, M.A., 2011, Effects of extreme climate events on the macrobenthic communities' structure and functioning of a temperate estuary: Marine Pollution Bulletin, v. 62, no. 2, p. 303-311, https://doi.org/10.1016/j.marpolbul.2010.10.010.

Günther, C.-P., 1992, Dispersal of intertidal invertebrates-A strategy to react to disturbances of different scales?: Netherlands Journal of Sea Research, v. 30, p. 45-56, https://doi.org/10.1016/0077-7579(92)90044-F.

Haaker, P.L., 1975, The biology of the California halibut, Paralichthys californicus (Ayres), in Anaheim Bay, California, in Lane, E.D., and Hill, C.W., eds., The marine resources of Anaheim Bay: California Department of Fish and Game Fish Bulletin, v. 165, p. 137-159.

Haderlie, E.C., and Abbott, D.P., 1980, Bivalvia-The clams and allies, in Morris, R.H., Abbott, D.P., and Haderlie, E.C., eds., Intertidal invertebrates of California (1st ed.): Stanford, Calif., Stanford University Press, p. 335-411. 
Hanson, C.H., Coil, J., Keller, B., Johnson, J., Taplin, J., and Monroe, J., 2004, Assessment and evaluation of the effects of sand mining on aquatic habitat and fishery populations of central San Francisco Bay and the Sacramento-San Joaquin Estuary: Hanson Environmental, Inc.

Hart, J.L., 1973, Pacific fishes of Canada-Ottowa: Fisheries Research Board of Canada Bulletin, v. 180, p. 1-740.

Haugen, C.W., 1990, The biological environment of the California halibut, Paralichthys californicus: Fish Bulletin, v. $174,475 \mathrm{p}$.

Herbold, B., 1987, Patterns of co-occurrence and resources use in a non-coevolved assemblage of fishes: Ph.D. dissertation, University of California, Davis, 68 p.

Hirsch, N.D., DiSalvo, L.H., and Peddicord, R., 1978, Effects of dredging and disposal on aquatic organisms: U.S. Army Corps of Engineers, Technical Report DS-78-5, Vicksburg, Miss., 41 p., https://apps.dtic.mil/dtic/tr/fulltext/u2/a058989.pdf.

Hobbs, J.A., Bennett, W.A., and Burton, J.E., 2006, Assessing nursery habitat quality for native smelts (Osmeridae) in the low-salinity zone of the San Francisco estuary: Journal of Fish Biology, v. 69, no. 3, p. 907-922, accessed April 1, 2014, at http://doi.wiley.com/10.1111/j.10958649.2006.01176.x.

Hogue, E.W., and Carey, A.G., Jr., 1982, Feeding ecology of 0 -age flatfishes at a nursery ground on the Oregon coast: Fish Bulletin, v. 80, p. 555-565, accessed February 13, 2015, at https://agris.fao.org/agris-search/search.do? recordID $=\mathrm{US} 19840065107$.

Holland, A.F., Mountford, N.K., Hiegel, M.H., Kaumeyer, K.R., and Mihursky, J.A., 1980, Influence of predation on infaunal abundance in Upper Chesapeake Bay, USA: Marine Biology, v. 57, no. 3, p. 221-235, https://doi.org/10.1007/BF00390739.

Hunter, J., 1977, Behavior and survival of northern anchovy Engraulis mordax larvae: Califorina Cooperative Oceanic Fisheries Investigations, v. 19, p. 138-146, http://calcofi.org/publications/calcofireports/v19/Vol_19 Hunter.pdf.

Israel, J.A., and Klimley, A.P., 2008, Life history conceptual model for North American green sturgeon (Acipenser medirostris): Davis, University of California, 49 p., https://nrm.dfg.ca.gov/FileHandler.ashx? DocumentID $=29310$.

Jensen, G.C., and Asplen, M.K., 1998, Omnivory in the diet of juvenile dungeness crab, Cancer magister Dana: Journal of Experimental Marine Biology and Ecology, v. 226, no. 2, p. 175-182, https://doi.org/10.1016/S0022-0981(97)00244-X.
Jones, M.L., 1961, Lightiella serendipita gen. nov., sp. nov., a cephalocarid from San Francisco Bay, California: Crustaceana, v. 3, no. 1, p. 31-46, https://doi.org/10.1163/156854061X00518.

Kao, J.S., 2000, Diet, daily ration and gastric evacuation of the leopard shark (Triakis semifasciata): A university thesis presented to the faculty of California State University, Hayward, 96 p.

Kenny, A.J., and Rees, H.L., 1994, The effects of marine gravel extraction on the macrobenthos-Early post-dredging recolonization: Marine Pollution Bulletin, v. 28, no. 7, p. 442-447, https://doi.org/10.1016/0025-326X(94)90130-9.

Krone, R.B., 1979, Sedimentation in the San Francisco Bay system, in Conomos, T.J., ed., San Francisco BayThe urbanized estuary:Pacific Division of the American Association for the Advancement of Science, p. 85-96, http://downloads.ice.ucdavis.edu/sfestuary/conomos_1979/ archive1020.PDF.

LaSalle, M.W., 1990, Physical and chemical alterations associated with dredging-An overview: Seattle, Wash., Effects of dredging on anadromous Pacific Coast fishes, Workshop Proceedings, p. 1-12.

Lassuy, D.R., 1989, Species profiles-Life histories and environmental requirements of coastal fishes and invertebrates (Pacific Northwest)_English Sole: U.S. Army Corps of Engineers, Biological Report 82, TR EL-82-4, 17 p.

Lebednik, P., 2004, Framework for assessment of potential effects of dredging on sensitive fish species in San Francisco Bay_Final report: Ecosystem Services Group, San Francisco, Calif., 141 p.

Lee, H., II, Thompson, B., and Lowe, S., 2003, Estuarine and scalar patterns of invasion in the soft-bottom benthic communities of the San Francisco estuary: Biological Invasions, v. 5, no. 1-2, p. 85-102, https://doi.org/10.1023/A:1024038522256.

Leong, R.J.H., and O’Connell, C.P., 1969, A laboratory study of particulate and filter feeding of the Northern Anchovy (Engraulis mordax): Journal of the Fisheries Research Board of Canada, v. 26, no. 3, p. 557-582, https://doi.org/10.1139/f69-053.

Longhurst, A.R., 1971, The Clupeoid resources of tropical seas: Oceanography and Marine Biology — an Annual Review, v. 9, p. 349-385, https://swfsc.noaa.gov/ publications/cr/1971/7128.pdf.

Love, M.S., Yoklavich, M., and Thorsteinson, L., 2002, The rockfishes of the northeast Pacific: Berkeley, Calif., University of California Press, 416 p. 
Lovvorn, J.R., De La Cruz, S.E.W., Takekawa, J.Y., Shaskey, L.E., and Richman, S.E., 2013, Niche overlap, threshold food densities, and limits to prey depletion for a diving duck assemblage in an estuarine bay: Marine Ecology Progress Series, v. 476, p. 251-268, https://doi.org/10.3354/meps10104.

Lundquist, C.J., Thrush, S.F., Oldman, J.W., and Senior, A.K., 2004, Limited transport and recolonization potential in shallow tidal estuaries: Limnology and Oceanography, v. 49, no. 2, p. 386-395, https://doi.org/10.4319/lo.2004.49.2.0386.

Lunz, J.D., and Kendall, D.R., 1982, Benthic resources assessment technique, a method for quantifying the effects of benthic community changes on fish resources: Oceans, v. 82, p. 1021-1027, https://doi.org/10.1109/OCEANS.1982.1151822.

Madon, S.P., 2002, Ecophysiology of juvenile California halibut Paralichthys californicus in relation to body size, water temperature and salinity: Marine Ecology Progress Series, v. 243, p. 235-249, https://doi.org/10.3354/meps243235.

Markmann, C., 1986, Benthic monitoring in the SacramentoSan Joaquin Delta-Results from 1975 through 1981: Department of Water Resources, Interagency Ecology Study Program for the Sacramento-San Joaquin Estuary, Technical Report 12, $62 \mathrm{p}$.

McCabe, G.T., Jr., Emmett, R.L., and Hinton, S.A., 1993, Feeding ecology of juvenile white sturgeon (Acipenser transmontanus) in the lower Columbia River: Northwest Science, v. 67, no. 3, p. 170-180, http://hdl.handle.net/2376/1588.

McCall, J.N., 1992, Source of harpacticoid copepods in the diet of juvenile starry flounder: Marine Ecology Progress Series, v. 86, p. 41-50, https://doi.org/10.3354/meps086041.

McCall, P.L., 1977, Community patterns and adaptive strategies of infaunal benthos of Long Island Sound: Journal of Marine Research, v. 35, no. 2, p. 221-266, https://images.peabody.yale.edu/publications/jmr/jmr3502-01.pdf.

McFarlane, G., Schweigert, J., Detering, J., and Hodes, V., 2010, Diet analysis of pacific sardine (Sardinops sagax) off the west coast of Vancouver Island, British Columbia from 1997 to 2008: California Cooperative Oceanic Fisheries Investigations Report, v. 51, p. 169-181, https://calcofi.org/publications/calcofireports/v51/Vol51_ CalCOFI_Reports.pdf.

McKechnie, R.J., and Fenner, R.B., 1971, Food habits of white sturgeon, Acipenser transmontanus, in San Pablo and Suisun bays, California: California Fish and Game, v. 57, no. 3, p. 209-212.
Miller, B.S., 1967, Stomach contents of adult starry flounder and sand sole in East Sound, Orcas Island, Washington: Journal of the Fisheries Research Board of Canada, v. 24, no. 12 , p. 2515-2526, https://doi.org/10.1139/f67-201.

Miller, M.J., 2004, The ecology and functional morphology of feeding of North American Sturgeon and Paddlefish, in LeBreton, G.T.O., Beamish, W.H., and McKinley, R.S., eds., Sturgeons and paddlefish of North America: Springer, Dordrecht, The Netherlands, p. 87-102, https://doi.org/10.1007/1-4020-2833-4_5.

Miller, T.W., and Brodeur, R.D., 2007, Diets of and trophic relationships among dominant marine nekton within the northern California current ecosystem: Fish Bulletin, v. 105, no. 4, p. 548-559, https://spo.nmfs.noaa.gov/sites/default/ files/pdf-content/2007/1054/miller.pdf.

Moore, J.W., and Moore, I.A., 1976, The basis of food selection in flounders, Platichthys flesus (L.), in the Severn Estuary: Journal of Fish Biology, v. 9, no. 2, p. 139-156, https://doi.org/10.1111/j.1095-8649.1976.tb04669.x.

Motta, P.J., and Wilga, C.D., 2001, Advances in the study of feeding behaviors, mechanisms, and mechanics of sharks: Environmental Biology of Fishes, v. 60, no. 1-3, p. 131-156, https://doi.org/10.1023/A:1007649900712.

Moyle, P.B., 2002, Inland fishes of California, revised and expanded: Berkeley, University of California Press, 517 p.

Moyle, P.B., and Davis, L.H., 2000, A list of freshwater, anadromous, and euryhaline fishes of California: California Fish and Game, v. 86, no. 4, p. 244-258, https://nrm.dfg.ca.gov/FileHandler.ashx? DocumentID $=83921$.

Muir, W.D., Emmett, R.L., and McConnell, R.J., 1988, Diet of juvenile and subadult white sturgeon in the lower Columbia River and its estuary: California Fish and Game, v. 74, p. 49-54.

Munuera Fernandez, I.M., and Gonzalez-Quiros, R., 2006, Analysis of feeding of Sebastes auriculatus (Walbaum, 1792) larval stages in the central Cantabrian Sea: Scientia Marina, v. 70, no. S1, p. 131-139, https://doi.org/10.3989/scimar.2006.70s1131.

Newell, R.C., Seiderer, L.J., and Hitchcock, D.R., 1998, The impact of dredging works in coastal waters-A review of the sensitivity to disturbance and subsequent recovery of biological resources on the sea bed: Oceanography and Marine Biology, v. 36, p. 127-178, https://www.researchgate.net/publication/298415859 The_impact_of_dredging_works_in_coastal_waters_a review_of_the_sensitivity_to_disturbance_and_subsequent recovery_of_biological_resources_on_the_sea_bed. 
Nichols, F.H., Cloern, J.E., Luoma, S.N., and Peterson, D.H., 1986, The modification of an estuary: Science, v. 231 , no. 4738 , p. 567-573, https://doi.org/10.1126/science.231.4738.567.

Nichols, F.H., and Pamatmat, M.M., 1988, The ecology of the soft-bottom benthos of San Francisco Bay-A community profile: U.S. Fish and Wildlife Service Biological Report 85, 73 p., https://apps.dtic.mil/dtic/tr/fulltext/u2/a322690.pdf.

Nightingale, B., and Simenstad, C.A., 2001, Executive Summary-Overwater structures-Marine issues:Washington State Transportation Center (TRAC), University of Washington, 6 p., https://www.wsdot.wa.gov/ research/reports/fullreports/508.2.pdf.

Oliver, J.S., Slattery, P.N., Hulberg, L.W., and Nybakken, J.W., 1977, Patterns of succession in benthic infaunal communities following dredging and dredged material disposal in Monterey Bay: U.S. Army Engineer Waterways Experiment Station, Technical Report D-77-27, 186 p., http://aquaticcommons.org/2612/1/Tech_Report_D77-27.pdf.

Orcutt, H.G., 1950, The life history of the starry flounder Platichthys stellatus (Pallas): California Department of Fish and Game, Fish Bulletin no. 78, 101 p., https://escholarship.org/uc/item/3c74b3bj.

Parrish, R.H., Mallicoate, D.L., and Mais, K.F., 1985, Regional variations in the growth and age composition of northern anchovy, Engraulis mordax: NOAA National Marine Fisheries Service Fishery Bulletin, v. 83, no. 4, p. 483-496, https://swfsc.noaa.gov/publications/cr/1985/8567.pdf.

Peterson, H.A., and Vayssieres, M., 2010, Benthic assemblage variability in the upper San Francisco Estuary-A 27-year retrospective: San Francisco Estuary and Watershed Science, v. 8, no. 1, 27 p., https://doi.org/10.15447/sfews.2010v8iss1art2.

Piet, G.J., Pfisterer, A.B., and Rijnsdorp, A.D., 1998, On factors structuring the flatfish assemblage in the southern North Sea: Journal of Sea Research, v. 40, no. 1-2, p. 143-152, https://doi.org/10.1016/S1385-1101(98)00008-2.

Plummer, K.M., Demartini, E.E., and Roberts, D.A., 1983, The feeding habits and distribution of juvenile-small adult California halibut (Paralichthys californicus) in coastal waters off northern San Diego County: California Cooperative Oceanic Fisheries Investigations Report, v. 24, p. 194-201, http://calcofi.org/publications/calcofireports/ v24/Vol_24_Plummer_etal.pdf.
Quinn, G.P., and Keough, M.J., 2002, Experimental design and data analysis for biologists: Cambridge, U.K., Cambridge University Press, 558 p., https://doi.org/10.1017/CBO9780511806384.

R Development Core Team, 2017, R-A language and environment for statistical computing: Vienna, Austria, R Foundation for Statistical Computing, https://www.R-project.org/.

Radtke, L.D., 1966, Distribution of smelt, juvenile sturgeon, and starry flounder in the Sacramento-San Joaquin Delta with observations on food of sturgeon: Ecological Studies of the Sacramento-San Joaquin Estuary, Part II: Department of Fish and Game, Fish Bulletin no. 136, p. 115-119.

Ray, G.L., 2005, Ecological functions of shallow, unvegetated estuarine habitats and potential dredging impacts (with emphasis on Chesapeake Bay) Wetlands Regulatory Assistance Program, Technical Notes Collection, ERDC TN-WRAP-05-3: U.S. Army Engineer Research and Development Center, Vicksburg, Miss., 13 p., https://pdfs.semanticscholar.org/3183/ 584e17b7724e69a6bd5db9656feac16c3746.pdf.

Ray, G.L., Clarke, D.G., Engler, R.M., Wilber, D., and Brostoff, W., 2005, Sedimentation-Potential biological effects of dredging operations in estuarine and marine environments: Vicksburg, Miss., U.S. Army Engineer Research and Development Center, Technical Note DOER-E20, 14 p., https://clu-in.org/download/ contaminantfocus/sediments/potential-biological-effectsdoere20.pdf.

Reecht, Y., Rochet, M.J., Trenkel, V.M., Jennings, S., and Pinnegar, J.K., 2013, Use of morphological characteristics to define functional groups of predatory fishes in the Celtic sea: Journal of Fish Biology, v. 83, no. 2, p. 355-377, https://doi.org/10.1111/jfb.12177.

Rees, H.L., and Dare, P.J., 1993, Sources of mortality and associated life-cycle traits of selected benthic species-A review: Ministry of Agriculture, Fisheries, and Food, Fisheries Research Data Report no. 33, 36 p., https://www.cefas.co.uk/publications/files/datarep33.pdf.

Reilly, F.J., Clarke, J.U., McFarland, V.A., Lutz, C.H., and Jarvis, A.S., 1992, Review and analysis of the literature regarding potential impacts of dredged material disposal in central San Francisco Bay on fisheries and contaminant bioavailability: Vicksburg, Miss., U.S. Army Corps of Engineers Waterway Experiment Station, Miscellaneous Paper EL-92, 99 p.

Rhoads, D.C., and Germano, J.D., 1986, Interpreting long-term changes in benthic community structure-A new protocol: Hydrobiologia, v. 142, no. 1, p. 291-308, https://doi.org/10.1007/BF00026766. 
Ricciardi, A., and Bourget, E., 1998, Weight-to-weight conversion factors for marine benthic macroinvertebrates: Marine Ecology Progress Series, v. 163, p. 245-251, https://doi.org/10.3354/meps163245.

Rich, A.A., 2010, Potential impacts of re-suspended sediments associated with dredging and dredged material placement on fishes in San Francisco Bay, CaliforniaLiterature review and identification of data gaps: U.S. Army Corps of Engineers, San Francisco, Calif., 75 p., https://www.spn.usace.army.mil/Portals/68/docs/ Dredging/LMTS/S\%20and\%20S/7\%20-\%20LTMS\%20 Literature\%20Review_Effects\%20of\%20Resuspended $\% 20$ Sediments.pdf.

Richman, S.E., and Lovvorn, J.R., 2004, Relative foraging value to lesser scaup ducks of native and exotic clams from San Francisco Bay: Ecological Applications, v. 14, no. 4, p. 1217-1231, https://doi.org/10.1890/03-5032.

Roberts, D.E., Smith, A., Ajani, P., and Davis, A.R., 1998a, Rapid changes in encrusting marine assemblages exposed to anthropogenic point-source pollution-A "Beyond BACI" approach: Marine Ecology Progress Series, v. 163, p. 213-224, https://doi.org/10.3354/meps163213.

Roberts, R.D., Gregory, M.R., and Foster, B.A., 1998b, Developing an efficient macrofauna monitoring index from an impact study - A dredge spoil example: Marine Pollution Bulletin, v. 36, no. 3, p. 231-235, https://doi.org/10.1016/S0025-326X(97)00183-5.

Robinson, H.J., Cailliet, G.M., and Ebert, D.A., 2007, Food habits of the longnose skate, Raja rhina (Jordan and Gilbert, 1880), in central California waters: Environmental Biology of Fishes, v. 80, no. 2-3, p. 165-179, https://doi.org/10.1007/s10641-007-9222-9.

Rodil, I.F., Lohrer, A.M., Hewitt, J.E., Townsend, M., Thrush, S.F., and Carbines, M., 2013, Tracking environmental stress gradients using three biotic integrity indices-Advantages of a locally-developed traits-based approach: Ecological Indicators, v. 34, p. 560-570, https://doi.org/10.1016/j.ecolind.2013.06.023.

Russo, R.A., 1975, Observations on the food habits of leopard sharks (Triakis semifasciata) and brown smoothhounds (Mustelus henlei): California Fish and Game, v. 61, no. 2, p. 95-103.

Schemel, L.E., Ota, A.Y., Harmon, J.G., Shay, J.M., and Adorador, R.N., 1988, Benthic macrofauna and ancillary data for San Francisco Bay, California, March to November 1987: U.S. Geological Survey Open-File Report 88-192, 73 p., https://doi.org/10.3133/ofr88192.
Schemel, L.E., Ota, A.Y., Harmon, J.G., Shay, J.M., and Adorador, R.M., 1990, Benthic macrofauna and ancillary data for San Francisco Bay, California, January to November 1988: U.S. Geological Survey Open-File Report 89-596, 65 p., https://doi.org/10.3133/ofr89596.

Shellenbarger, G.G., Wright, S.A., and Schoellhamer, D.H., 2013, A sediment budget for the southern reach in San Francisco Bay, CA-Implications for habitat restoration: Marine Geology, v. 345, p. 281-293, https://doi.org/10.1016/j.margeo.2013.05.007.

Simenstad, C.A., Tanner, C.D., Thom, R.M., and Conquest, L.L., 1991, Estuarine habitat assessment protocol: Seattle, Wash., National Service Center for Environmental Publicaitons, EPA 910/9-91-037, 144 p., https://nepis.epa.gov/Exe/ZyPURL.cgi?Dockey= 91024WTI.TXT.

Skinner, J.E., 1962, Sturgeon fishery and status California, 1962, in Skinner, J.E., ed. Fish and Wildlife Resources of the San Francisco Bay Area: California Water Projects Branch Report, no. 1, 11 p., Sacramento, Calif., http://www.swrcb.ca.gov/waterrights/water_issues/ programs/bay_delta/deltaflow/docs/exhibits/swrcb/swrcb_ skinner1962.pdf.

Stasinopoulos, D.M., and Rigby, R.A., 2007, Generalized additive models for location scale and shape (GAMLSS) in R: Journal of Statistical Software, v. 23, no. 7, 46 p., https://doi.org/10.18637/jss.v023.i07.

Steidl, R.J., Hayes, J.P., and Schauber, E., 1997, Statistical power analysis in wildlife research: The Journal of Wildlife Management, v. 61, no. 2, p. 270-279, https://doi.org/10.2307/3802582.

Stewart, R.A., Luoma, S.N., Schlekat, C.E., Doblin, M.A., and Hieb, K.A., 2004, Food web pathway determines how selenium affects aquatic ecosystems-A San Francisco Bay case study: Environmental Science and Technology, v. 38, no. 17, p. 4519-4526, https://doi.org/10.1021/es0499647.

Swain, D., Langenbrunner, B., Neelin, J.D., and Hall, A., 2018, Increasing precipitation volatility in twenty-first-century California: Nature Climate Change, v. 8, no. 5, p. 427-433, https://doi.org/10.1038/s41558-018-0140-y.

Talent, L.G., 1976, Food habits of leopard shark, Triakis semifasciata, in Elkhorn Slough, Monterey Bay, California: California Fish and Game, v. 62, no. 4, p. 286-298, https://www.cabi.org/isc/abstract/19771453560.

Thompson, B., Lowe, S., and Kellogg, M., 2000, Results of the benthic pilot study 1994-1997-Part 1-Macrobenthic assemblages of the San Francisco Bay-Delta, and their responses to abiotic factors: , San Francisco, Calif., San Francisco Estuary Institute and the Aquatic Science Center. 
Thompson, B., Ranasinghe, J.A., Lowe, S., Melwani, A., and Weisberg, S.B., 2013, Benthic macrofaunal assemblages of the San Francisco Estuary and Delta, USA: Environmental Monitoring and Assessment, v. 185, no. 3, p. 2281-2295, https://doi.org/10.1007/s10661-012-2708-8.

Thompson, J., Hieb, K., McGourty, K., Cosentino-Manning, N., Wainwright-De La Cruz, S., Elliot, M., and Allen, S., 2007, Habitat type and associated biological assemblages - Soft bottom substrate, in Schaeffer, K., McGourty, K.R., Cosentio-Manning, N., and Allen, S.G., eds., Report on the subtidal habitats and associated biological taxa in San Francisco Bay: National Oceanic and Atmospheric Administration, p. 37-46.

Toole, C.L., 1980, Intertidal recruitment and feeding in relation to optimal utilization of nursery areas by juvenile English sole (Parophrys vetulus-Pleuronectidae): Environmental Biology of Fishes, v. 5, no. 4, p. 383-390, https://doi.org/10.1007/BF00005192.

U.S. Fish and Wildlife Service, 1980, Habitat Evaluation Procedures (HEP) ESM 102: Washington D.C., Division of Ecological Services, https://www.fws.gov/policy/ESM102.pdf.

Underwood, A.J., 1994, On beyond BACI—Sampling designs that might reliably detect environmental disturbances: Ecological Applications, v. 4, no. 1, p. 3-15, https://doi.org/10.2307/1942110.

van Denderen, P.D., van Kooten, T., and Rijnsdorp, A.D., 2013, When does fishing lead to more fish? Community consequences of bottom trawl fisheries in demersal food webs: Proceedings of the Royal Society B, Biological Sciences, v. 280, no. 1769, 8 p., https://doi.org/10.1098/rspb.2013.1883.

Van Der Veer, H.W., Bergman, M.J.N., and Beukema, J.J., 1985, Dredging activities in the Dutch Wadden Sea-Effects on macrobenthic infauna: Netherlands Journal of Sea Research, v. 19, no. 2, p. 183-190, https://doi.org/10.1016/0077-7579(85)90022-5. van der Wegen, M., Jaffe, B., Foxgrover, A., and Roelvink, D., 2017, Mudflat morphodynamics and the impact of sea level rise in south San Francisco Bay: Estuaries and Coasts, v. 40, no. 1, p. 37-49, https://doi.org/10.1007/s12237-016-0129-6.

van Duren, L.A., and Middelburg, J.J., 2001, The benthic boundary layer - Transport processes and biogeochemistry: Eos (Washington, D.C.), v. 82, no. 52, p. 658-659, https://doi.org/10.1029/01EO00381.

Washington, P.M., Gowan, R., and Ito, D.H., 1978, A biological report on eight species of rockfish (Sebastes spp.) from Puget Sound, Washington: Seattle, Wash., National Oceanic Atmospheric Administration, 50 p., https://www.afsc.noaa.gov/Publications/ProcRpt/PR1978_ Washington_rockfish.pdf.

Weigelhofer, G., and Waringer, J., 2003, Vertical distribution of benthic macroinvertebrates in riffles versus deep runs with differing contents of fine sediments (Weidlingbach, Austria): International Review of Hydrobiology, v. 88, no. 3-4, p. 304-313, https://doi.org/10.1002/iroh.200390027.

Weihs, C., Ligges, U., Luebke, K., and Raabe, N., 2005, klaR analyzing German business cycles, in Baier D., Decker R., and Schmidt-Thieme, L., eds., Data analysis and decision support: Berlin, Springer Verlag, p. 335-343, https://doi.org/10.1007/3-540-28397-8_36.

Wilber, D.H., and Clarke, D.G., 2007, Defining and assessing benthic recovery following dredging and dredged material disposal: Orlando, Fla., World Dredging Congress.

Wilber, D.H., Ray, G.L., Clarke, D.G., and Diaz, R.J., 2008, Responses of benthic infauna to large-scale sediment disturbance in Corpus Christi Bay, Texas: Journal of Experimental Marine Biology and Ecology, v. 365, no. 1, p. 13-22, https://doi.org/10.1016/j.jembe.2008.07.029.

Yang, M.S., 2007, Food habits and diet overlap of seven skate species in the Aleutian Islands: NOAA Technical Memorandum NMFS-AFSC-177, 47 p. 


\section{Appendix 1.}

\section{Supplemental tables and figures}

Table 1.1. GLMM results for total density of $0-4 \mathrm{~mm}$ macroinvertebrates from 0 to $4 \mathrm{~cm}$ depth at six sites (Loch Lomond, Mooring Road, Paradise Cay, Richardson Bay, Strawberry Channel, and Yacht Harbor) with dredged and undredged areas.

[Cores were collected during summer and winter 2016-17. Collection site and transects were included in the GLMM as random effects. Abbreviation: $<$, less than]

\begin{tabular}{lcccc}
\hline \multicolumn{1}{c}{ Fixed effect } & Estimate & $\begin{array}{c}\text { Standard } \\
\text { error }\end{array}$ & t-value & $\boldsymbol{p}$ \\
\hline $\begin{array}{l}\text { Intercept } \\
\text { Treatment: }\end{array}$ & 2.107 & 0.203 & 10.365 & $<0.001$ \\
$\quad$ undredged & 0.332 & 0.063 & 5.284 & $<0.001$ \\
$\quad$ Season: winter & 0.490 & 0.112 & 4.368 & $<0.001$ \\
Salinity & 0.033 & 0.007 & 5.062 & $<0.001$ \\
Elevation & -0.200 & 0.055 & -3.652 & $<0.001$ \\
\hline
\end{tabular}

Table 1.3. GLMM results for total density of $12-24 \mathrm{~mm}$ macroinvertebrates from 0 to $4 \mathrm{~cm}$ depth at six sites (Loch Lomond, Mooring Road, Paradise Cay, Richardson Bay, Strawberry Channel, and Yacht Harbor) with dredged and undredged areas.

[Cores were collected during summer and winter 2016-17. Collection site and transects were included in the GLMM as random effects. Abbreviation: $<$, less than]

\begin{tabular}{lcccc}
\hline \multicolumn{1}{c}{ Fixed effect } & Estimate & $\begin{array}{c}\text { Standard } \\
\text { error }\end{array}$ & t-value & $\boldsymbol{p}$ \\
\hline Intercept & 1.330 & 0.346 & 3.842 & $<0.001$ \\
$\begin{array}{l}\text { Treatment: } \\
\quad \text { undredged }\end{array}$ & 0.302 & 0.090 & 3.347 & 0.001 \\
$\quad$ Season: winter & -0.783 & 0.279 & -2.801 & 0.005 \\
Salinity & -0.018 & 0.012 & -1.555 & 0.120 \\
Elevation & 0.182 & 0.078 & 2.343 & 0.019 \\
\hline
\end{tabular}

Table 1.2. GLMM results for total density of 4-12 mm macroinvertebrates from 0 to $4 \mathrm{~cm}$ depth at six sites (Loch Lomond, Mooring Road, Paradise Cay, Richardson Bay, Strawberry Channel, and Yacht Harbor) with dredged and undredged areas.

[Cores were collected during summer and winter 2016-17. Collection site and transects were included in the GLMM as random effects. Abbreviation: $<$, less than]

\begin{tabular}{lcccc}
\hline \multicolumn{1}{c}{ Fixed effect } & Estimate & $\begin{array}{c}\text { Standard } \\
\text { error }\end{array}$ & t-value & $\boldsymbol{p}$ \\
\hline Intercept & 1.914 & 0.238 & 8.048 & $<0.001$ \\
$\quad$ Treatment: & 0.402 & 0.072 & 5.588 & $<0.001$ \\
$\quad$ undredged & & & & \\
Season: winter & -0.797 & 0.142 & -5.611 & $<0.001$ \\
Salinity & -0.033 & 0.008 & -4.111 & $<0.001$ \\
Elevation & -0.279 & 0.058 & -4.780 & $<0.001$ \\
\hline
\end{tabular}

Table 1.4. GLMM results for total density of $24-50 \mathrm{~mm}$ macroinvertebrates from 0 to $4 \mathrm{~cm}$ depth at six sites (Loch Lomond, Mooring Road, Paradise Cay, Richardson Bay, Strawberry Channel, and Yacht Harbor) with dredged and undredged areas.

[Cores were collected during summer and winter 2016-17. Collection site and transects were included in the GLMM as random effects. Abbreviation: $<$, less than]

\begin{tabular}{lrrrc}
\hline \multicolumn{1}{c}{ Fixed effect } & Estimate & $\begin{array}{c}\text { Standard } \\
\text { error }\end{array}$ & t-value & $\boldsymbol{p}$ \\
\hline Intercept & -1.252 & 1.815 & -0.690 & 0.490 \\
$\quad \begin{array}{l}\text { Treatment: } \\
\quad \text { undredged }\end{array}$ & 0.359 & 0.114 & 3.149 & 0.002 \\
$\quad$ Season: winter & 1.186 & 1.693 & 0.700 & 0.484 \\
Salinity & 0.042 & 0.064 & 0.664 & 0.507 \\
Elevation & -0.239 & 0.217 & -1.102 & 0.271 \\
\hline
\end{tabular}


Table 1.5. GLMM results for total density of $0-50 \mathrm{~mm}$ macroinvertebrates from 0 to $10 \mathrm{~cm}$ depth at six sites (Loch Lomond, Mooring Road, Paradise Cay, Richardson Bay, Strawberry Channel, and Yacht Harbor) with dredged and undredged areas.

[Cores were collected during summer and winter 2016-17. Collection site and transects were included in the GLMM as random effects. Abbreviation: $<$, less than]

\begin{tabular}{lrrrr}
\hline \multicolumn{1}{c}{ Fixed effect } & Estimate & $\begin{array}{c}\text { Standard } \\
\text { error }\end{array}$ & t-value & $\boldsymbol{p}$ \\
\hline Intercept & 2.834 & 0.194 & 14.586 & $<0.001$ \\
$\begin{array}{l}\text { Treatment: } \\
\quad \text { undredged }\end{array}$ & 0.420 & 0.061 & 6.927 & $<0.001$ \\
Season: winter & 0.243 & 0.107 & 2.268 & 0.024 \\
Salinity & 0.014 & 0.006 & 2.279 & 0.023 \\
Elevation & -0.187 & 0.053 & -3.538 & $<0.001$ \\
\hline
\end{tabular}

Table 1.7. GLMM results for total biomass of $0-4 \mathrm{~mm}$ macroinvertebrates from 0 to $4 \mathrm{~cm}$ depth at six sites (Loch Lomond, Mooring Road, Paradise Cay, Richardson Bay, Strawberry Channel, and Yacht Harbor) with dredged and undredged areas.

[Cores were collected during summer and winter 2016-17. Collection site and transects were included in the GLMM as random effects. Abbreviation: $<$, less than]

\begin{tabular}{lrrrc}
\hline \multicolumn{1}{c}{ Fixed effect } & Estimate & $\begin{array}{c}\text { Standard } \\
\text { error }\end{array}$ & t-value & $\boldsymbol{p}$ \\
\hline Intercept & -1.233 & 0.287 & -4.294 & $<0.001$ \\
Treatment: & 0.736 & 0.100 & 7.336 & $<0.001$ \\
$\quad$ undredged & & & & \\
Season: winter & 1.229 & 0.172 & 7.147 & $<0.001$ \\
Salinity & 0.135 & 0.010 & 14.081 & $<0.001$ \\
Elevation & 0.241 & 0.083 & 2.919 & 0.004 \\
\hline
\end{tabular}

Table 1.6. GLMM results for total density of $0-50 \mathrm{~mm}$ macroinvertebrates from 0 to $10 \mathrm{~cm}$ depth at six sites (Loch Lomond, Mooring Road, Paradise Cay, Richardson Bay, Strawberry Channel, and Yacht Harbor) with dredged and undredged areas.

[Cores were collected during summer and winter 2015-17. Collection site and transects were included in the GLMM as random effects.

Abbreviation: $<$, less than]

\begin{tabular}{lrrrc}
\hline \multicolumn{1}{c}{ Fixed effect } & Estimate & $\begin{array}{c}\text { Standard } \\
\text { error }\end{array}$ & t-value & $\boldsymbol{p}$ \\
\hline Intercept & 3.531 & 0.146 & 24.227 & $<0.001$ \\
$\quad \begin{array}{l}\text { Treatment: } \\
\quad \text { undredged }\end{array}$ & 0.458 & 0.059 & 7.730 & $<0.001$ \\
Season: winter & -0.161 & 0.069 & -2.326 & 0.020 \\
Salinity & -0.010 & 0.005 & -2.174 & 0.030 \\
Elevation & -0.203 & 0.053 & -3.843 & $<0.001$ \\
\hline
\end{tabular}

Table 1.8. GLMM results for total biomass of 4-12 mm macroinvertebrates from 0 to $4 \mathrm{~cm}$ depth at six sites (Loch Lomond, Mooring Road, Paradise Cay, Richardson Bay, Strawberry Channel, and Yacht Harbor) with dredged and undredged areas.

[Cores were collected during summer and winter 2016-17. Collection site and transects were included in the GLMM as random effects. Abbreviation: $<$, less than]

\begin{tabular}{lrrrr}
\hline \multicolumn{1}{c}{ Fixed effect } & Estimate & $\begin{array}{c}\text { Standard } \\
\text { error }\end{array}$ & t-value & $\boldsymbol{p}$ \\
\hline Intercept & 5.548 & 0.429 & 12.936 & $<0.001$ \\
$\quad \begin{array}{l}\text { Treatment: } \\
\quad \text { undredged }\end{array}$ & 0.610 & 0.151 & 4.050 & $<0.001$ \\
Season: winter & -3.464 & 0.258 & -13.429 & $<0.001$ \\
Salinity & -0.074 & 0.015 & -5.046 & $<0.001$ \\
Elevation & -0.100 & 0.123 & -0.813 & 0.417 \\
\hline
\end{tabular}


Table 1.9. GLMM results for total biomass of 12-24 mm macroinvertebrates from 0 to $4 \mathrm{~cm}$ depth at six sites (Loch Lomond, Mooring Road, Paradise Cay, Richardson Bay, Strawberry Channel, and Yacht Harbor) with dredged and undredged areas.

[Cores were collected during summer and winter 2016-17. Collection site and transects were included in the GLMM as random effects. Abbreviation: $<$, less than]

\begin{tabular}{lrrrr}
\hline \multicolumn{1}{c}{ Fixed effect } & Estimate & $\begin{array}{c}\text { Standard } \\
\text { error }\end{array}$ & t-value & $\boldsymbol{p}$ \\
\hline Intercept & 6.704 & 0.412 & 16.254 & $<0.001$ \\
Treatment: & -0.226 & 0.108 & -2.100 & 0.036 \\
$\quad$ undredged & & & & \\
Season: winter & -0.938 & 0.339 & -2.765 & 0.006 \\
Salinity & -0.022 & 0.014 & -1.589 & 0.112 \\
Elevation & 0.294 & 0.093 & 3.161 & 0.002 \\
\hline
\end{tabular}

Table 1.11. GLMM results for total biomass of $0-50 \mathrm{~mm}$ macroinvertebrates from 0 to $10 \mathrm{~cm}$ depth at six sites (Loch Lomond, Mooring Road, Paradise Cay, Richardson Bay, Strawberry Channel, and Yacht Harbor) with dredged and undredged areas.

[Cores were collected during summer and winter 2016-17. Collection site and transects were included in the GLMM as random effects. Abbreviation: $<$, less than]

\begin{tabular}{lrrrr}
\hline \multicolumn{1}{c}{ Fixed effect } & Estimate & $\begin{array}{c}\text { Standard } \\
\text { error }\end{array}$ & t-value & $\boldsymbol{p}$ \\
\hline Intercept & 5.658 & 0.309 & 18.292 & $<0.001$ \\
$\quad$ Treatment: & 1.022 & 0.120 & 8.537 & $<0.001$ \\
$\quad$ undredged & & & & \\
Season: winter & -1.943 & 0.184 & -10.554 & $<0.001$ \\
Salinity & -0.027 & 0.011 & -2.534 & 0.012 \\
Elevation & -0.296 & 0.095 & -3.110 & 0.002 \\
\hline
\end{tabular}

Table 1.10. GLMM results for total biomass of $24-50 \mathrm{~mm}$ macroinvertebrates from 0 to $4 \mathrm{~cm}$ depth at six sites (Loch Lomond, Mooring Road, Paradise Cay, Richardson Bay, Strawberry Channel, and Yacht Harbor) with dredged and undredged areas.

[Cores were collected during summer and winter 2016-17. Collection site and transects were included in the GLMM as random effects.

Abbreviation: $<$, less than]

\begin{tabular}{lrrrr}
\hline \multicolumn{1}{c}{ Fixed effect } & Estimate & $\begin{array}{c}\text { Standard } \\
\text { error }\end{array}$ & t-value & $\boldsymbol{p}$ \\
\hline Intercept & 24.185 & 1.828 & 13.227 & $<0.001$ \\
Treatment: & 0.159 & 0.116 & 1.376 & 0.169 \\
$\quad$ undredged & & & & \\
Season: winter & -16.280 & 1.706 & -9.540 & $<0.001$ \\
Salinity & -0.625 & 0.064 & -9.722 & $<0.001$ \\
Elevation & -1.326 & 0.221 & -6.004 & $<0.001$ \\
\hline
\end{tabular}

Table 1.12. GLMM results for total energy of $0-4 \mathrm{~mm}$ macroinvertebrates from 0 to $4 \mathrm{~cm}$ depth at six sites (Loch Lomond, Mooring Road, Paradise Cay, Richardson Bay, Strawberry Channel, and Yacht Harbor) with dredged and undredged areas.

[Cores were collected during summer and winter 2016-17. Collection site and transects were included in the GLMM as random effects. Abbreviation: $<$, less than]

\begin{tabular}{lccrc}
\hline \multicolumn{1}{c}{ Fixed effect } & Estimate & $\begin{array}{c}\text { Standard } \\
\text { error }\end{array}$ & t-value & $\boldsymbol{p}$ \\
\hline Intercept & 1.370 & 0.289 & 4.746 & $<0.001$ \\
$\begin{array}{l}\text { Treatment: } \\
\quad \text { undredged }\end{array}$ & 0.710 & 0.102 & 6.985 & $<0.001$ \\
$\quad$ Season: winter & 1.294 & 0.174 & 7.442 & $<0.001$ \\
Salinity & 0.142 & 0.010 & 14.707 & $<0.001$ \\
Elevation & 0.247 & 0.084 & 2.929 & 0.004 \\
\hline
\end{tabular}


Table 1.13. GLMM results for total energy of $4-12 \mathrm{~mm}$ macroinvertebrates from 0 to $4 \mathrm{~cm}$ depth at six sites (Loch Lomond, Mooring Road, Paradise Cay, Richardson Bay, Strawberry Channel, and Yacht Harbor) with dredged and undredged areas.

[Cores were collected during summer and winter 2016-17. Collection site and transects were included in the GLMM as random effects.

Abbreviation: $<$, less than]

\begin{tabular}{lrrrr}
\hline \multicolumn{1}{c}{ Fixed effect } & Estimate & $\begin{array}{c}\text { Standard } \\
\text { error }\end{array}$ & t-value & $\boldsymbol{p}$ \\
\hline Intercept & 5.693 & 0.364 & 15.656 & $<0.001$ \\
Treatment: & 0.595 & 0.123 & 4.852 & $<0.001$ \\
$\quad$ undredged & & & & \\
Season: winter & -2.246 & 0.217 & -10.347 & $<0.001$ \\
Salinity & -0.039 & 0.012 & -3.096 & 0.002 \\
Elevation & -0.170 & 0.099 & -1.713 & 0.087 \\
\hline
\end{tabular}

Table 1.15. GLMM results for total energy of 24-50 mm macroinvertebrates from 0 to $4 \mathrm{~cm}$ depth at six sites (Loch Lomond, Mooring Road, Paradise Cay, Richardson Bay, Strawberry Channel, and Yacht Harbor) with dredged and undredged areas.

[Cores were collected during summer and winter 2016-17. Collection site and transects were included in the GLMM as random effects. Abbreviation: $<$, less than]

\begin{tabular}{lrrrr}
\hline \multicolumn{1}{c}{ Fixed effect } & Estimate & $\begin{array}{c}\text { Standard } \\
\text { error }\end{array}$ & t-value & $\boldsymbol{p}$ \\
\hline Intercept & 23.253 & 1.793 & 12.968 & $<0.001$ \\
Treatment: & 0.131 & 0.114 & 1.154 & 0.249 \\
$\quad$ undredged & & & & \\
Season: winter & -14.339 & 1.674 & -8.568 & $<0.001$ \\
Salinity & -0.551 & 0.063 & -8.736 & $<0.001$ \\
Elevation & -1.149 & 0.216 & -5.310 & $<0.001$ \\
\hline
\end{tabular}

Table 1.14. GLMM results for total energy of 12-24 mm macroinvertebrates from 0 to $4 \mathrm{~cm}$ depth at six sites (Loch Lomond, Mooring Road, Paradise Cay, Richardson Bay, Strawberry Channel, and Yacht Harbor) with dredged and undredged areas.

[Cores were collected during summer and winter 2016-17. Collection site and transects were included in the GLMM as random effects. Abbreviation: $<$, less than]

\begin{tabular}{lrrrr}
\hline \multicolumn{1}{c}{ Fixed effect } & Estimate & $\begin{array}{c}\text { Standard } \\
\text { error }\end{array}$ & t-value & $\boldsymbol{p}$ \\
\hline Intercept & 6.867 & 0.447 & 15.365 & $<0.001$ \\
$\quad \begin{array}{l}\text { Treatment: } \\
\quad \text { undredged }\end{array}$ & -0.085 & 0.117 & -0.728 & 0.467 \\
Season: winter & -0.022 & 0.370 & -0.060 & 0.952 \\
Salinity & 0.013 & 0.015 & 0.829 & 0.408 \\
Elevation & 0.345 & 0.101 & 3.410 & 0.001 \\
\hline
\end{tabular}

Table 1.16. GLMM results for total energy of $0-50 \mathrm{~mm}$ macroinvertebrates from 0 to $10 \mathrm{~cm}$ depth at six sites with dredged and undredged areas.

[Cores were collected during summer and winter 2016-17. Collection site and transects were included in the GLMM as random effects. Abbreviation: $<$, less than]

\begin{tabular}{lrrrc}
\hline \multicolumn{1}{c}{ Fixed effect } & Estimate & $\begin{array}{c}\text { Standard } \\
\text { error }\end{array}$ & t-value & $\boldsymbol{p}$ \\
\hline Intercept & 5.936 & 0.282 & 21.056 & $<0.001$ \\
$\quad \begin{array}{l}\text { Treatment: } \\
\quad \text { undredged }\end{array}$ & 1.083 & 0.107 & 10.088 & $<0.001$ \\
Season: winter & -0.414 & 0.171 & -2.417 & 0.016 \\
Salinity & 0.031 & 0.010 & 3.207 & 0.001 \\
Elevation & 0.023 & 0.086 & 0.262 & 0.794 \\
\hline
\end{tabular}


Table 1.17. GLMM results for the effects of distance from a dredged area on total density of 0-4 mm macroinvertebrates from 0 to $4 \mathrm{~cm}$ depth at six sites (Loch Lomond, Mooring Road, Paradise Cay, Richardson Bay, Strawberry Channel, and Yacht Harbor).

[Cores were collected during summer and winter 2016-17. Collection site and transects were included in the GLMM as random effects. Abbreviation: $<$, less than]

\begin{tabular}{lcccc}
\hline \multicolumn{1}{c}{ Fixed effect } & Estimate & $\begin{array}{c}\text { Standard } \\
\text { error }\end{array}$ & t-value & $\boldsymbol{p}$ \\
\hline Intercept & 2.283 & 0.202 & 11.283 & $<0.001$ \\
$\begin{array}{l}\text { Distance from } \\
\quad \text { dredged area }\end{array}$ & -0.002 & 0.001 & -2.030 & 0.043 \\
Season: winter & 0.496 & 0.112 & 4.445 & $<0.001$ \\
Salinity & 0.034 & 0.007 & 5.260 & $<0.001$ \\
Elevation & -0.238 & 0.054 & -4.427 & $<0.001$ \\
\hline
\end{tabular}

Table 1.19. GLMM results for the effects of distance from a dredged area on total density of 12-24 mm macroinvertebrates from 0 to $4 \mathrm{~cm}$ depth at six sites (Loch Lomond, Mooring Road, Paradise Cay, Richardson Bay, Strawberry Channel, and Yacht Harbor).

[Cores were collected during summer and winter 2016-17. Collection site and transects were included in the GLMM as random effects. Abbreviation: $<$, less than]

\begin{tabular}{lrrrr}
\hline \multicolumn{1}{c}{ Fixed effect } & Estimate & $\begin{array}{c}\text { Standard } \\
\text { error }\end{array}$ & t-value & $\boldsymbol{p}$ \\
\hline Intercept & 1.377 & 0.341 & 4.040 & $<0.001$ \\
$\begin{array}{l}\text { Distance from } \\
\quad \text { dredged area }\end{array}$ & 0.003 & 0.001 & 2.969 & 0.003 \\
Season: winter & -0.765 & 0.280 & -2.737 & 0.006 \\
Salinity & -0.017 & 0.012 & -1.506 & 0.133 \\
Elevation & 0.093 & 0.078 & 1.190 & 0.235 \\
\hline
\end{tabular}

Table 1.18. GLMM results for the effects of distance from a dredged area on total density of 4-12 mm macroinvertebrates from 0 to $4 \mathrm{~cm}$ depth at six sites (Loch Lomond, Mooring Road, Paradise Cay, Richardson Bay, Strawberry Channel, and Yacht Harbor).

[Cores were collected during summer and winter 2016-17. Collection site and transects were included in the GLMM as random effects.

Abbreviation: $<$, less than]

\begin{tabular}{lcccc}
\hline \multicolumn{1}{c}{ Fixed effect } & Estimate & $\begin{array}{c}\text { Standard } \\
\text { error }\end{array}$ & t-value & $\boldsymbol{p}$ \\
\hline Intercept & 2.015 & 0.238 & 8.451 & $<0.001$ \\
Distance from & 0.004 & 0.001 & 4.361 & $<0.001$ \\
$\quad$ dredged area & & & & \\
Season: winter & -0.810 & 0.143 & -5.678 & $<0.001$ \\
Salinity & -0.034 & 0.008 & -4.248 & $<0.001$ \\
Elevation & -0.347 & 0.058 & -6.005 & $<0.001$ \\
\hline
\end{tabular}

Table 1.20. GLMM results for the effects of distance from a dredged area on total density of 0-50 $\mathrm{mm}$ macroinvertebrates from 0 to $10 \mathrm{~cm}$ depth at six sites (Loch Lomond, Mooring Road, Paradise Cay, Richardson Bay, Strawberry Channel, and Yacht Harbor).

[Cores were collected during summer and winter 2016-17. Collection site and transects were included in the GLMM as random effects.

Abbreviation: $<$, less than]

\begin{tabular}{lrrrr}
\hline \multicolumn{1}{c}{ Fixed effect } & Estimate & $\begin{array}{c}\text { Standard } \\
\text { error }\end{array}$ & t-value & $\boldsymbol{p}$ \\
\hline Intercept & 3.018 & 0.194 & 15.586 & $<0.001$ \\
$\begin{array}{l}\text { Distance from } \\
\quad \text { dredged area }\end{array}$ & -0.001 & 0.001 & -0.801 & 0.423 \\
Season: winter & 0.253 & 0.107 & 2.377 & 0.018 \\
Salinity & 0.016 & 0.006 & 2.477 & 0.013 \\
Elevation & -0.233 & 0.052 & -4.468 & $<0.001$ \\
\hline
\end{tabular}


Table 1.21. GLMM results for the effects of distance from a dredged area on total density of $0-50 \mathrm{~mm}$ macroinvertebrates from 0 to $10 \mathrm{~cm}$ depth at six sites (Loch Lomond, Mooring Road, Paradise Cay, Richardson Bay, Strawberry Channel, and Yacht Harbor).

[Cores were collected during summer and winter 2015-17. Collection site and transects were included in the GLMM as random effects.

Abbreviation: $<$, less than]

\begin{tabular}{lrrrr}
\hline \multicolumn{1}{c}{ Fixed effect } & Estimate & $\begin{array}{c}\text { Standard } \\
\text { error }\end{array}$ & t-value & $\boldsymbol{p}$ \\
\hline Intercept & 3.716 & 0.146 & 25.522 & $<0.001$ \\
$\begin{array}{l}\text { Distance from } \\
\quad \text { dredged area }\end{array}$ & 0.001 & 0.001 & 0.669 & 0.504 \\
Season: winter & -0.157 & 0.069 & -2.256 & 0.024 \\
Salinity & -0.009 & 0.005 & -2.034 & 0.042 \\
Elevation & -0.249 & 0.052 & -4.765 & $<0.001$ \\
\hline
\end{tabular}

Table 1.23. GLMM results for the effects of distance from a dredged area on total biomass of 4-12 mm macroinvertebrates from 0 to $4 \mathrm{~cm}$ depth at six sites (Loch Lomond, Mooring Road, Paradise Cay, Richardson Bay, Strawberry Channel, and Yacht Harbor).

[Cores were collected during summer and winter 2016-17. Collection site and transects were included in the GLMM as random effects. Abbreviation: $<$, less than]

\begin{tabular}{lrrrr}
\hline \multicolumn{1}{c}{ Fixed effect } & Estimate & $\begin{array}{c}\text { Standard } \\
\text { error }\end{array}$ & t-value & $\boldsymbol{p}$ \\
\hline Intercept & 5.712 & 0.428 & 13.353 & $<0.001$ \\
Distance from & 0.003 & 0.002 & 1.502 & 0.134 \\
$\quad$ dredged area & & & & \\
Season: winter & -3.441 & 0.258 & -13.321 & $<0.001$ \\
Salinity & -0.073 & 0.015 & -4.975 & $<0.001$ \\
Elevation & -0.176 & 0.121 & -1.452 & 0.147 \\
\hline
\end{tabular}

Table 1.22. GLMM results for the effects of distance from a dredged area on total biomass of 0-4 mm macroinvertebrates from 0 to $4 \mathrm{~cm}$ depth at six sites (Loch Lomond, Mooring Road, Paradise Cay, Richardson Bay, Strawberry Channel, and Yacht Harbor).

[Cores were collected during summer and winter 2016-17. Collection site and transects were included in the GLMM as random effects.

Abbreviation: $<$, less than]

\begin{tabular}{lrrrr}
\hline \multicolumn{1}{c}{ Fixed effect } & Estimate & $\begin{array}{c}\text { Standard } \\
\text { error }\end{array}$ & t-value & $\boldsymbol{p}$ \\
\hline Intercept & -0.811 & 0.282 & -2.879 & 0.004 \\
$\begin{array}{l}\text { Distance from } \\
\quad \text { dredged area }\end{array}$ & -0.002 & 0.001 & -2.076 & 0.038 \\
Season: winter & 1.196 & 0.162 & 7.389 & $<0.001$ \\
Salinity & 0.134 & 0.009 & 14.476 & $<0.001$ \\
Elevation & 0.075 & 0.081 & 0.926 & 0.355 \\
\hline
\end{tabular}

Table 1.24. GLMM results for the effects of distance from a dredged area on total biomass taxa of 12-24 mm macroinvertebrates from 0 to $4 \mathrm{~cm}$ depth at six sites (Loch Lomond, Mooring Road, Paradise Cay, Richardson Bay, Strawberry Channel, and Yacht Harbor).

[Cores were collected during summer and winter 2016-17. Collection site and transects were included in the GLMM as random effects. Abbreviation: $<$, less than]

\begin{tabular}{lcccr}
\hline \multicolumn{1}{c}{ Fixed effect } & Estimate & $\begin{array}{c}\text { Standard } \\
\text { error }\end{array}$ & t-value & $\boldsymbol{p}$ \\
\hline Intercept & 6.622 & 0.409 & 16.179 & $<0.001$ \\
$\begin{array}{l}\text { Distance from } \\
\quad \text { dredged area }\end{array}$ & -0.001 & 0.001 & -0.809 & 0.419 \\
$\quad$ Season: winter & -0.944 & 0.339 & -2.786 & 0.005 \\
Salinity & -0.022 & 0.014 & -1.601 & 0.110 \\
Elevation & 0.333 & 0.093 & 3.571 & $<0.001$ \\
\hline
\end{tabular}


Table 1.25. GLMM results for the effects of distance from a dredged area on total biomass of 24-50 mm macroinvertebrates from 0 to $4 \mathrm{~cm}$ depth at six sites (Loch Lomond, Mooring Road, Paradise Cay, Richardson Bay, Strawberry Channel, and Yacht Harbor).

[Cores were collected during summer and winter 2016-17. Collection site and transects were included in the GLMM as random effects. Abbreviation: $<$, less than]

\begin{tabular}{lrrrr}
\hline \multicolumn{1}{c}{ Fixed effect } & Estimate & $\begin{array}{c}\text { Standard } \\
\text { error }\end{array}$ & t-value & $\boldsymbol{p}$ \\
\hline Intercept & 24.247 & 1.857 & 13.059 & $<0.001$ \\
$\begin{array}{l}\text { Distance from } \\
\quad \text { dredged area }\end{array}$ & 0.001 & 0.002 & 0.518 & 0.605 \\
Season: winter & -16.240 & 1.725 & -9.416 & $<0.001$ \\
Salinity & -0.624 & 0.065 & -9.563 & $<0.001$ \\
Elevation & -1.287 & 0.220 & -5.852 & $<0.001$ \\
\hline
\end{tabular}

Table 1.27. GLMM results for the effects of distance from a dredged area on total energy of 0-4 mm macroinvertebrates from 0 to $4 \mathrm{~cm}$ depth at six sites (Loch Lomond, Mooring Road, Paradise Cay, Richardson Bay, Strawberry Channel, and Yacht Harbor).

[Cores were collected during summer and winter 2016-17. Collection site and transects were included in the GLMM as random effects. Abbreviation: $<$, less than]

\begin{tabular}{lrrrr}
\hline \multicolumn{1}{c}{ Fixed effect } & Estimate & $\begin{array}{c}\text { Standard } \\
\text { error }\end{array}$ & t-value & $\boldsymbol{p}$ \\
\hline Intercept & 1.764 & 0.283 & 6.242 & $<0.001$ \\
$\begin{array}{l}\text { Distance from } \\
\quad \text { dredged area }\end{array}$ & -0.003 & 0.001 & -2.154 & 0.032 \\
Season: winter & 1.266 & 0.164 & 7.740 & $<0.001$ \\
Salinity & 0.142 & 0.009 & 15.227 & $<0.001$ \\
Elevation & 0.088 & 0.082 & 1.068 & 0.286 \\
\hline
\end{tabular}

Table 1.26. GLMM results for the effects of distance from a dredged area on total biomass of $0-50 \mathrm{~mm}$ macroinvertebrates from 0 to $10 \mathrm{~cm}$ depth at six sites (Loch Lomond, Mooring Road, Paradise Cay, Richardson Bay, Strawberry Channel, and Yacht Harbor).

[Cores were collected during summer and winter 2016-17. Collection site and transects were included in the GLMM as random effects.

Abbreviation: $<$, less than]

\begin{tabular}{lrrrr}
\hline \multicolumn{1}{c}{ Fixed effect } & Estimate & $\begin{array}{c}\text { Standard } \\
\text { error }\end{array}$ & t-value & $\boldsymbol{p}$ \\
\hline Intercept & 5.587 & 0.307 & 18.198 & $<0.001$ \\
Distance from & 0.008 & 0.001 & 5.529 & $<0.001$ \\
$\quad$ dredged area & & & & \\
Season: winter & -1.758 & 0.173 & -10.165 & $<0.001$ \\
Salinity & -0.020 & 0.010 & -1.942 & 0.053 \\
Elevation & -0.512 & 0.094 & -5.452 & $<0.001$ \\
\hline
\end{tabular}

Table 1.28. GLMM results for the effects of distance from a dredged area on total energy of 4-12 mm macroinvertebrates from 0 to $4 \mathrm{~cm}$ depth at six sites (Loch Lomond, Mooring Road, Paradise Cay, Richardson Bay, Strawberry Channel, and Yacht Harbor).

[Cores were collected during summer and winter 2016-17. Collection site and transects were included in the GLMM as random effects.

Abbreviation: $<$, less than]

\begin{tabular}{lrrrr}
\hline \multicolumn{1}{c}{ Fixed effect } & Estimate & $\begin{array}{c}\text { Standard } \\
\text { error }\end{array}$ & t-value & $\boldsymbol{p}$ \\
\hline Intercept & 5.841 & 0.363 & 16.097 & $<0.001$ \\
Distance from & 0.003 & 0.001 & 1.874 & 0.061 \\
$\quad$ dredged area & & & & \\
Season: winter & -2.213 & 0.217 & -10.203 & $<0.001$ \\
Salinity & -0.037 & 0.012 & -2.962 & 0.003 \\
Elevation & -0.226 & 0.098 & -2.298 & 0.022 \\
\hline
\end{tabular}


Table 1.29. GLMM results for the effects of distance from a dredged area on total energy of 12-24 mm macroinvertebrates from 0 to $4 \mathrm{~cm}$ depth at six sites (Loch Lomond, Mooring Road, Paradise Cay, Richardson Bay, Strawberry Channel, and Yacht Harbor).

[Cores were collected during summer and winter 2016-17. Collection site and transects were included in the GLMM as random effects. Abbreviation: $<$, less than]

\begin{tabular}{lrrrr}
\hline \multicolumn{1}{c}{ Fixed effect } & Estimate & $\begin{array}{c}\text { Standard } \\
\text { error }\end{array}$ & t-value & $\boldsymbol{p}$ \\
\hline Intercept & 6.883 & 0.446 & 15.438 & $<0.001$ \\
$\begin{array}{l}\text { Distance from } \\
\quad \text { dredged area }\end{array}$ & -0.002 & 0.001 & -1.088 & 0.277 \\
Season: winter & -0.025 & 0.371 & -0.067 & 0.946 \\
Salinity & 0.013 & 0.015 & 0.815 & 0.415 \\
Elevation & 0.391 & 0.101 & 3.853 & $<0.001$ \\
\hline
\end{tabular}

Table 1.31. GLMM results for the effects of distance from a dredged area on total energy of $0-50 \mathrm{~mm}$ macroinvertebrates from 0 to $10 \mathrm{~cm}$ depth at six sites (Loch Lomond, Mooring Road, Paradise Cay, Richardson Bay, Strawberry Channel, and Yacht Harbor).

[Cores were collected during summer and winter 2016-17. Collection site and transects were included in the GLMM as random effects.

Abbreviation: $<$, less than]

\begin{tabular}{lrrrr}
\hline \multicolumn{1}{c}{ Fixed effect } & Estimate & $\begin{array}{c}\text { Standard } \\
\text { error }\end{array}$ & t-value & $\boldsymbol{p}$ \\
\hline Intercept & 5.931 & 0.279 & 21.223 & $<0.001$ \\
Distance from & 0.006 & 0.001 & 4.669 & $<0.001$ \\
$\quad$ dredged area & & & & \\
Season: winter & -0.240 & 0.161 & -1.492 & 0.136 \\
Salinity & 0.039 & 0.009 & 4.117 & $<0.001$ \\
Elevation & -0.223 & 0.085 & -2.624 & 0.009 \\
\hline
\end{tabular}

Table 1.30. GLMM results for the effects of distance from a dredged area on total energy of 24-50 mm macroinvertebrates from 0 to $4 \mathrm{~cm}$ depth at six sites (Loch Lomond, Mooring Road, Paradise Cay, Richardson Bay, Strawberry Channel, and Yacht Harbor).

[Cores were collected during summer and winter 2016-17. Collection site and transects were included in the GLMM as random effects.

Abbreviation: $<$, less than]

\begin{tabular}{lrrrr}
\hline \multicolumn{1}{c}{ Fixed effect } & Estimate & $\begin{array}{c}\text { Standard } \\
\text { error }\end{array}$ & t-value & $\boldsymbol{p}$ \\
\hline Intercept & 23.345 & 1.821 & 12.818 & $<0.001$ \\
$\begin{array}{l}\text { Distance from } \\
\quad \text { dredged area }\end{array}$ & 0.001 & 0.002 & 0.568 & 0.570 \\
Season: winter & -14.343 & 1.692 & -8.478 & $<0.001$ \\
Salinity & -0.552 & 0.064 & -8.615 & $<0.001$ \\
Elevation & -1.108 & 0.215 & -5.148 & $<0.001$ \\
\hline
\end{tabular}

Table 1.32. GLMM results for the effects time since an area was dredged on total density of 0-4 mm macroinvertebrates from 0 to $4 \mathrm{~cm}$ depth at six sites (Loch Lomond, Mooring Road, Paradise Cay, Richardson Bay, Strawberry Channel, and Yacht Harbor).

[Cores were collected during summer and winter 2016-17. Collection site and transects were included in the GLMM as random effects. Abbreviation: $<$, less than]

\begin{tabular}{lcccc}
\hline \multicolumn{1}{c}{ Fixed effect } & Estimate & $\begin{array}{c}\text { Standard } \\
\text { error }\end{array}$ & t-value & $\boldsymbol{p}$ \\
\hline Intercept & 2.457 & 0.329 & 7.473 & $<0.001$ \\
$\begin{array}{l}\text { Years since an area } \\
\quad \text { was dredged }\end{array}$ & 0.088 & 0.060 & 1.463 & 0.144 \\
$\quad$ Season: winter & 0.421 & 0.195 & 2.159 & 0.032 \\
Salinity & 0.018 & 0.011 & 1.690 & 0.092 \\
Elevation & 0.118 & 0.080 & 1.474 & 0.141 \\
\hline
\end{tabular}


Table 1.33. GLMM results for the effects time since an area was dredged on total density of 4-12 mm macroinvertebrates from 0 to $4 \mathrm{~cm}$ depth at six sites (Loch Lomond, Mooring Road, Paradise Cay, Richardson Bay, Strawberry Channel, and Yacht Harbor).

[Cores were collected during summer and winter 2016-17. Collection site and transects were included in the GLMM as random effects. Abbreviation: $<$, less than]

\begin{tabular}{lrrrr}
\hline \multicolumn{1}{c}{ Fixed effect } & Estimate & $\begin{array}{c}\text { Standard } \\
\text { error }\end{array}$ & t-value & $\boldsymbol{p}$ \\
\hline Intercept & 1.998 & 0.350 & 5.706 & $<0.001$ \\
Years since an area & 0.160 & 0.071 & 2.257 & 0.025 \\
$\quad$ was dredged & & & & \\
Season: winter & -0.927 & 0.223 & -4.156 & $<0.001$ \\
Salinity & -0.050 & 0.012 & -4.023 & $<0.001$ \\
Elevation & -0.228 & 0.081 & -2.822 & 0.005 \\
\hline
\end{tabular}

Table 1.35. GLMM results for the effects time since an area was dredged on total density of $0-50 \mathrm{~mm}$ macroinvertebrates from 0 to $10 \mathrm{~cm}$ depth at six sites (Loch Lomond, Mooring Road, Paradise Cay, Richardson Bay, Strawberry Channel, and Yacht Harbor).

[Cores were collected during summer and winter 2016-17. Collection site and transects were included in the GLMM as random effects.

Abbreviation: $<$, less than]

\begin{tabular}{lcccc}
\hline \multicolumn{1}{c}{ Fixed effect } & Estimate & $\begin{array}{c}\text { Standard } \\
\text { error }\end{array}$ & t-value & $\boldsymbol{p}$ \\
\hline Intercept & 2.753 & 0.315 & 8.753 & $<0.001$ \\
$\begin{array}{l}\text { Years since an area } \\
\quad \text { was dredged }\end{array}$ & 0.197 & 0.058 & 3.383 & 0.001 \\
$\quad$ Season: winter & 0.157 & 0.188 & 0.837 & 0.403 \\
Salinity & 0.006 & 0.011 & 0.597 & 0.551 \\
Elevation & 0.105 & 0.077 & 1.363 & 0.174 \\
\hline
\end{tabular}

Table 1.34. GLMM results for the effects time since an area was dredged on total density of 12-24 mm macroinvertebrates from 0 to $4 \mathrm{~cm}$ depth at six sites (Loch Lomond, Mooring Road, Paradise Cay, Richardson Bay, Strawberry Channel, and Yacht Harbor).

[Cores were collected during summer and winter 2016-17. Collection site and transects were included in the GLMM as random effects. Abbreviation: $<$, less than]

\begin{tabular}{lcccc}
\hline \multicolumn{1}{c}{ Fixed effect } & Estimate & $\begin{array}{c}\text { Standard } \\
\text { error }\end{array}$ & t-value & $\boldsymbol{p}$ \\
\hline Intercept & 0.492 & 0.438 & 1.124 & 0.262 \\
Years since an area & 0.193 & 0.079 & 2.451 & 0.015 \\
$\quad$ was dredged & & & & \\
Season: winter & -0.679 & 0.320 & -2.122 & 0.035 \\
Salinity & -0.002 & 0.013 & -0.167 & 0.868 \\
Elevation & 0.125 & 0.102 & 1.229 & 0.220 \\
\hline
\end{tabular}

Table 1.36. GLMM results for the effects time since an area was dredged on total density of $0-50 \mathrm{~mm}$ macroinvertebrates from 0 to $10 \mathrm{~cm}$ depth at six sites (Loch Lomond, Mooring Road, Paradise Cay, Richardson Bay, Strawberry Channel, and Yacht Harbor).

[Cores were collected during summer and winter 2015-17. Collection site and transects were included in the GLMM as random effects. Abbreviation: $<$, less than]

\begin{tabular}{lrrrr}
\hline \multicolumn{1}{c}{ Fixed effect } & Estimate & $\begin{array}{c}\text { Standard } \\
\text { error }\end{array}$ & t-value & $\boldsymbol{p}$ \\
\hline Intercept & 3.636 & 0.230 & 15.794 & $<0.001$ \\
$\begin{array}{l}\text { Years since an area } \\
\quad \text { was dredged }\end{array}$ & 0.153 & 0.059 & 2.601 & 0.010 \\
$\quad$ & & & \\
Season: winter & -0.245 & 0.125 & -1.965 & 0.050 \\
Salinity & -0.018 & 0.007 & -2.530 & 0.012 \\
Elevation & 0.182 & 0.076 & 2.384 & 0.018 \\
\hline
\end{tabular}


Table 1.37. GLMM results for the effects of time since an area was dredged on total biomass of 0-4 mm macroinvertebrates from 0 to $4 \mathrm{~cm}$ depth at six sites (Loch Lomond, Mooring Road, Paradise Cay, Richardson Bay, Strawberry Channel, and Yacht Harbor).

[Cores were collected during summer and winter 2016-17. Collection site and transects were included in the GLMM as random effects. Abbreviation: $<$, less than]

\begin{tabular}{lrrrr}
\hline \multicolumn{1}{c}{ Fixed effect } & Estimate & $\begin{array}{c}\text { Standard } \\
\text { error }\end{array}$ & t-value & $\boldsymbol{p}$ \\
\hline Intercept & -0.711 & 0.525 & -1.354 & 0.177 \\
Years since an area & 1.918 & 0.093 & 20.524 & $<0.001$ \\
$\quad$ was dredged & & & & \\
Season: winter & -2.938 & 0.283 & -10.398 & $<0.001$ \\
Salinity & -0.035 & 0.016 & -2.159 & 0.032 \\
Elevation & 0.357 & 0.121 & 2.945 & 0.003 \\
\hline
\end{tabular}

Table 1.39. GLMM results for the effects of time since an area was dredged on total biomass of 12-24 mm macroinvertebrates from 0 to $4 \mathrm{~cm}$ depth at six sites (Loch Lomond, Mooring Road, Paradise Cay, Richardson Bay, Strawberry Channel, and Yacht Harbor).

[Cores were collected during summer and winter 2016-17. Collection site and transects were included in the GLMM as random effects. Abbreviation: $<$, less than]

\begin{tabular}{lrrrr}
\hline \multicolumn{1}{c}{ Fixed effect } & Estimate & $\begin{array}{c}\text { Standard } \\
\text { error }\end{array}$ & t-value & $\boldsymbol{p}$ \\
\hline Intercept & 8.774 & 0.588 & 14.925 & $<0.001$ \\
Years since an area & -0.239 & 0.106 & -2.253 & 0.025 \\
$\quad$ was dredged & & & & \\
Season: winter & -2.068 & 0.436 & -4.744 & $<0.001$ \\
Salinity & -0.071 & 0.018 & -3.982 & $<0.001$ \\
Elevation & 0.189 & 0.136 & 1.387 & 0.167 \\
\hline
\end{tabular}

Table 1.38. GLMM results for the effects of time since an area was dredged on total biomass of 4-12 mm macroinvertebrates from 0 to $4 \mathrm{~cm}$ depth at six sites (Loch Lomond, Mooring Road, Paradise Cay, Richardson Bay, Strawberry Channel, and Yacht Harbor).

[Cores were collected during summer and winter 2016-17. Collection site and transects were included in the GLMM as random effects.

Abbreviation: $<$, less than]

\begin{tabular}{lcccc}
\hline \multicolumn{1}{c}{ Fixed effect } & Estimate & $\begin{array}{c}\text { Standard } \\
\text { error }\end{array}$ & t-value & $\boldsymbol{p}$ \\
\hline Intercept & 3.525 & 0.685 & 5.147 & $<0.001$ \\
Years since an area & 1.027 & 0.140 & 7.321 & $<0.001$ \\
$\quad$ was dredged & & & & \\
$\quad$ Season: winter & -3.771 & 0.408 & -9.251 & $<0.001$ \\
Salinity & -0.101 & 0.023 & -4.441 & $<0.001$ \\
$\quad$ Elevation & -0.332 & 0.175 & -1.896 & 0.059 \\
\hline
\end{tabular}

Table 1.40. GLMM results for the effects of time since an area was dredged on total biomass of $0-50 \mathrm{~mm}$ macroinvertebrates from 0 to $10 \mathrm{~cm}$ depth at six sites (Loch Lomond, Mooring Road, Paradise Cay, Richardson Bay, Strawberry Channel, and Yacht Harbor).

[Cores were collected during summer and winter 2016-17. Collection site and transects were included in the GLMM as random effects. Abbreviation: $<$, less than]

\begin{tabular}{lrrrr}
\hline \multicolumn{1}{c}{ Fixed effect } & Estimate & $\begin{array}{c}\text { Standard } \\
\text { error }\end{array}$ & t-value & $\boldsymbol{p}$ \\
\hline Intercept & 2.904 & 0.485 & 5.985 & $<0.001$ \\
Years since an area & 2.178 & 0.092 & 23.704 & $<0.001$ \\
$\quad$ was dredged & & & & \\
Season: winter & -4.753 & 0.283 & -16.787 & $<0.001$ \\
Salinity & -0.103 & 0.016 & -6.417 & $<0.001$ \\
Elevation & 0.099 & 0.122 & 0.817 & 0.414 \\
\hline
\end{tabular}


Table 1.41. GLMM results for the effects of time since an area was dredged on total energy of $0-4 \mathrm{~mm}$ macroinvertebrates from 0 to $4 \mathrm{~cm}$ depth at six sites (Loch Lomond, Mooring Road, Paradise Cay, Richardson Bay, Strawberry Channel, and Yacht Harbor).

[Cores were collected during summer and winter 2016-17. Collection site and transects were included in the GLMM as random effects. Abbreviation: $<$, less than]

\begin{tabular}{lrrrc}
\hline \multicolumn{1}{c}{ Fixed effect } & Estimate & $\begin{array}{c}\text { Standard } \\
\text { error }\end{array}$ & t-value & $\boldsymbol{p}$ \\
\hline Intercept & 2.163 & 0.529 & 4.090 & $<0.001$ \\
Years since an area & 1.919 & 0.095 & 20.220 & $<0.001$ \\
$\quad$ was dredged & & & & \\
Season: winter & -2.977 & 0.285 & -10.436 & $<0.001$ \\
Salinity & -0.039 & 0.016 & -2.361 & 0.019 \\
Elevation & 0.343 & 0.123 & 2.794 & 0.006 \\
\hline
\end{tabular}

Table 1.43. GLMM results for the effects of time since an area was dredged on total energy of 12-24 mm macroinvertebrates from 0 to $4 \mathrm{~cm}$ depth at six sites (Loch Lomond, Mooring Road, Paradise Cay, Richardson Bay, Strawberry Channel, and Yacht Harbor).

[Cores were collected during summer and winter 2016-17. Collection site and transects were included in the GLMM as random effects. Abbreviation: $<$, less than]

\begin{tabular}{lrrrr}
\hline \multicolumn{1}{c}{ Fixed effect } & Estimate & $\begin{array}{c}\text { Standard } \\
\text { error }\end{array}$ & t-value & $\boldsymbol{p}$ \\
\hline Intercept & 9.970 & 0.523 & 19.072 & $<0.001$ \\
Years since an area & -0.285 & 0.094 & -3.027 & 0.003 \\
$\quad$ was dredged & & & & \\
Season: winter & -1.919 & 0.388 & -4.948 & $<0.001$ \\
Salinity & -0.067 & 0.016 & -4.220 & $<0.001$ \\
Elevation & 0.185 & 0.122 & 1.524 & 0.129 \\
\hline
\end{tabular}

Table 1.42. GLMM results for the effects of time since an area was dredged on total energy of 4-12 mm macroinvertebrates from 0 to $4 \mathrm{~cm}$ depth at six sites (Loch Lomond, Mooring Road, Paradise Cay, Richardson Bay, Strawberry Channel, and Yacht Harbor).

[Cores were collected during summer and winter 2016-17. Collection site and transects were included in the GLMM as random effects. Abbreviation: $<$, less than]

\begin{tabular}{lcccc}
\hline \multicolumn{1}{c}{ Fixed effect } & Estimate & $\begin{array}{c}\text { Standard } \\
\text { error }\end{array}$ & t-value & $\boldsymbol{p}$ \\
\hline Intercept & 4.788 & 0.561 & 8.542 & $<0.001$ \\
Years since an area & 0.868 & 0.112 & 7.737 & $<0.001$ \\
$\quad$ was dredged & & & & \\
Season: winter & -3.054 & 0.334 & -9.135 & $<0.001$ \\
Salinity & -0.089 & 0.019 & -4.737 & $<0.001$ \\
Elevation & -0.411 & 0.137 & -3.008 & 0.003 \\
\hline
\end{tabular}

Table 1.44. GLMM results for the effects of time since an area was dredged on total energy of $0-50 \mathrm{~mm}$ macroinvertebrates from 0 to $10 \mathrm{~cm}$ depth at six sites (Loch Lomond, Mooring Road, Paradise Cay, Richardson Bay, Strawberry Channel, and Yacht Harbor).

[Cores were collected during summer and winter 2016-17. Collection site and transects were included in the GLMM as random effects. Abbreviation: $<$, less than]

\begin{tabular}{lrrrr}
\hline \multicolumn{1}{c}{ Fixed effect } & Estimate & $\begin{array}{c}\text { Standard } \\
\text { error }\end{array}$ & t-value & $\boldsymbol{p}$ \\
\hline Intercept & 4.857 & 0.469 & 10.356 & $<0.001$ \\
Years since an area & 1.868 & 0.085 & 22.057 & $<0.001$ \\
$\quad$ was dredged & & & & \\
Season: winter & -3.754 & 0.262 & -14.331 & $<0.001$ \\
Salinity & -0.077 & 0.015 & -5.102 & $<0.001$ \\
Elevation & 0.288 & 0.115 & 2.511 & 0.013 \\
\hline
\end{tabular}




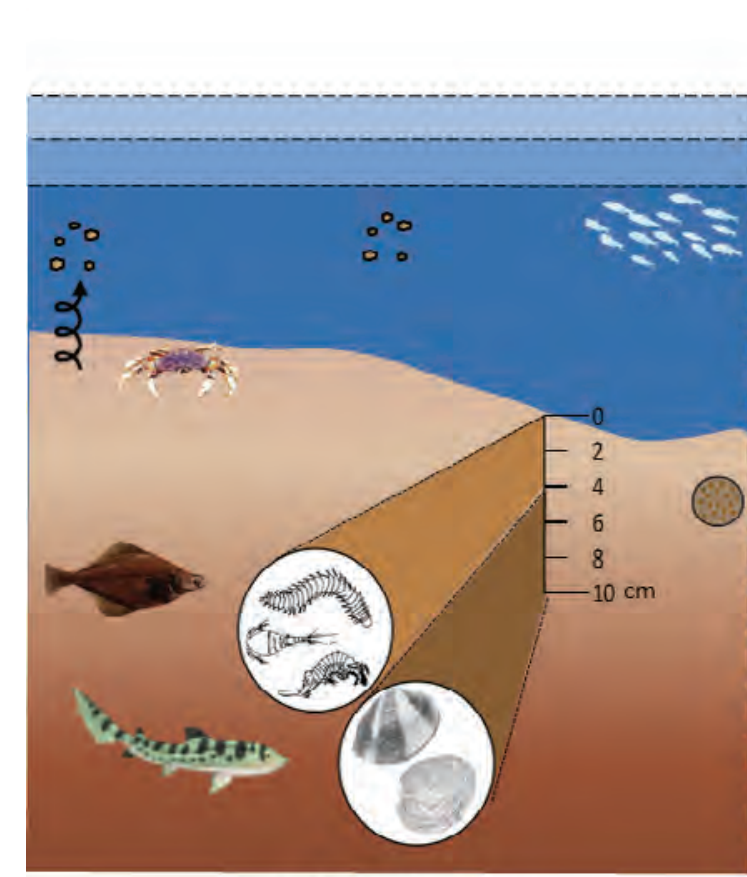

Undredged Area

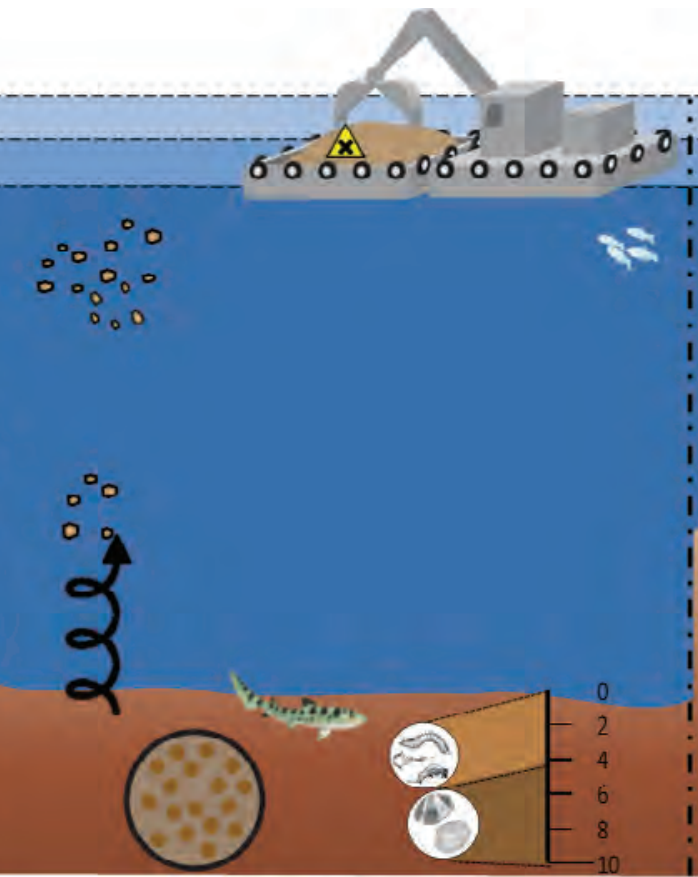

Dredged Arca
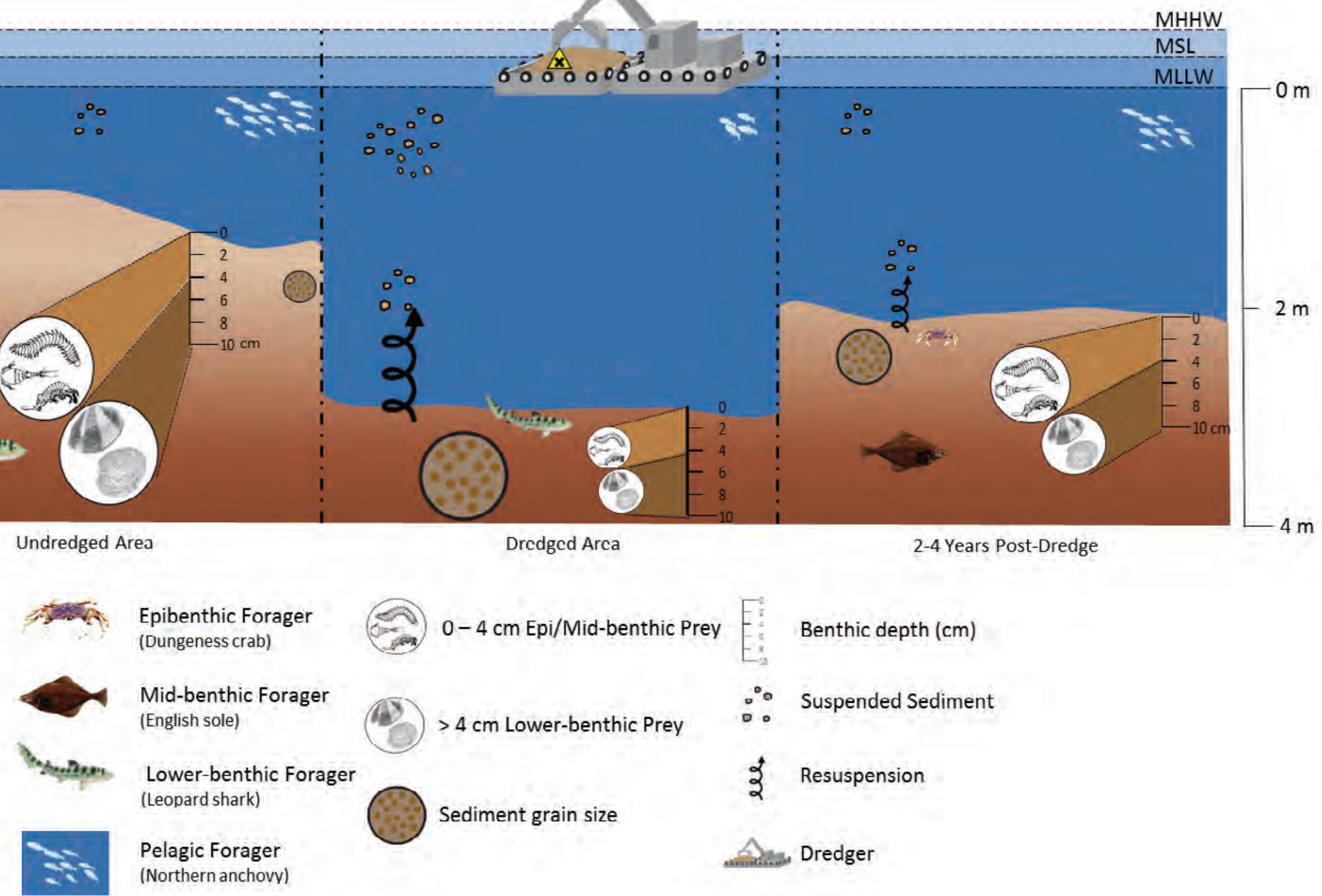

Figure 1.1. Conceptual diagram illustrating the comparison between an undredged benthic habitat (left), a recently a dredged area (center), and 2-4 years after dredging activity (right). Undredged areas are characterized by an abundant and diverse prey base of benthic infauna of varying size and depths. Turbidity is stable and sediment is stratified with smaller grains dominating the top $10-\mathrm{cm}$. Recently dredged areas result in the direct removal of shallow benthic habitat, resulting in increased suspended sediment. Post-dredging habitat is partially recovered, with medium sediment grain size providing habitat for smaller soft-bodied prey items. (Change in size of an object among panes indicates a conceptual shift in density, size, or magnitude. MHHW = Mean Higher High Water; MSL = Mean Sea Level; MLLW = Mean Lower Low Water. Not to scale.) 
For more information concerning the research in this report, contact the Director, Western Ecological Research Center

U.S. Geological Survey

3020 State University Drive East

Sacramento, California 95819

https://www.usgs.gov/centers/werc

Publishing support provided by the U.S. Geological Survey Science Publishing Network, Sacramento Publishing Service Center 
